\title{
A NATURAL
}

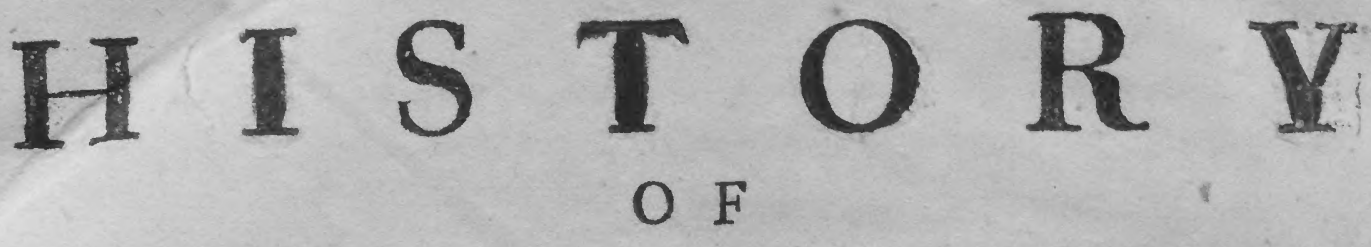

\section{ENGLISHINSECTS.}

Illuftrated with

A Hundred Copper Plates, curiounly Engraven from the Life:

And (for thofe wbo defire it) exactly Coloured by the A U T HOR. ELEAZAR ALBIN, Painter. To which are added, LARGE
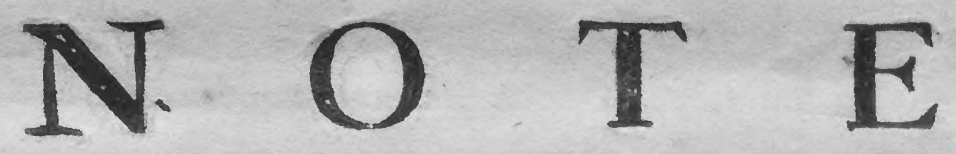

S,

And many Curious

\section{O B S E R A T I O N S. B Y}

W. DERHAM; Fellow of the Royal Society.

$$
\text { LONDON: }
$$

printed by Wiritam and Jонn Irnys, Printers to the Roya: Society, at the Weft-End of S. Paul's. MDCCXXIV. . 


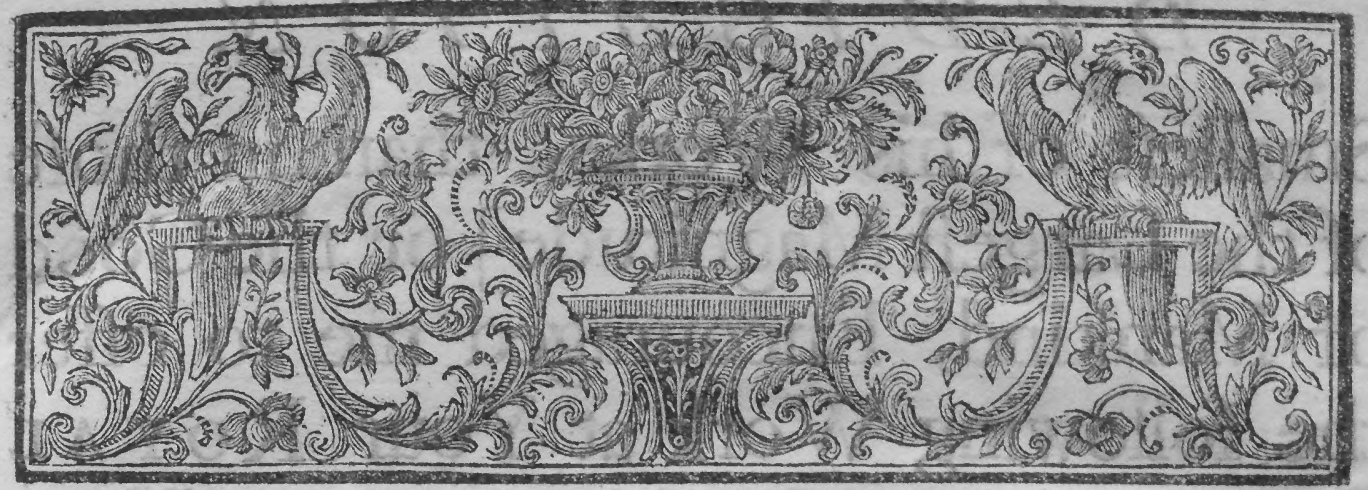

To Her ROY AL HIGHNES the

PRINCESS of WALES.

M A D A M,

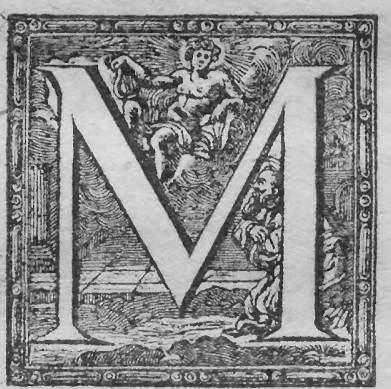

$Y$ profound Veneration for Your R O Y A L H I G HN E s s 's Perfon, had prevented this Prefumption; but Your readinefs in condefcending to Patronize whatfoever may tend to the Honour of God, [whofe infinite Power is no lefs vifible in the A 2 


\section{$D E D I C A T I O N$.}

Smalleft of his Works, than in thofe of the Largeft Magnitude] or the Good of Mankind, Encouraged me to offer the following Work at Your Roy aL FEe T, moft Humbly begging Your Pardon and Protection; who am, may it pleafe Your Royal Highness, with the greateft Duty,

Your Royal Highness's Moft Faithful, and Moft Obedienty Humble Servant,

ELEAZAR ALBIN. 


\section{P R E F A C E.}

TEACHING to Draw, and Paint in Water-Colours, being my Profeffion, firft led me to the obferving of Flowers and Infects, with whofe various Forms and beautiful Colours I was very much delighted, efpecially of the latter, feveral of which I painted after the Life, for my own Pleafure: After fome time this brought me acquainted with $\mathrm{Mr}$. Dandridge, a very ingenious $\mathrm{Man}$, and very curious in obferving the Works of Nature: He had diverted himfelf fome Years with collecting Infects, and obferving their feveral Progreffions from the Egg, thro' their Worm-State, to the Fly, which is their State of Perfection; this curious Perfon employed me in painting Caterpillars for him, and recommended me to Mrs. How, Widow of the late famous Phyfician of that Name: For this curious Lady I painted a great Number of both Caterpillars and Flies, and likewife feveral Things rełating to Natural Hiftory for Sir Hans Sloane: After this I was introduc'd to Her Grace Mary the late Dutchefs Dowager of Beaufort, who imployed me in the fame nanner; this. excellent Lady firft perfwaded me to undertake the following Work, and encouraged me by procuring me Subfcriptions from feveral Perfons of the firft Quality: While this good Lady lived it went on apace, and I am perfuaded had been finifhed long fince if it had pleafed God to have fpared her; but after the lofs of my Patronefs, Subfcriptions coming in flowly, and my Circumftances (having a great Family to provide for) not being able to carry it on without, retarded it. Thefe Confiderations I hope will difpofe thofe honourable and worthy Perfons who fubfribed. early to pardon me that they have expected it fo long. 


\section{$P R E F A C E$.}

'Thus much I thought proper to fay concerning what put me upon this Undertaking, and likewife to acquaint the World with the Reafons why it has been fo long in hand: I fhall now fay fomewhat of the Work it felf.

In the firf place, in all my Drawings, particularly of the Infects, I have copied exactly after the Life; having obferved it as a great Fault in thofe who have gone before me in this Way; that they either did not look often enough at their Pattern, ox affected to make the Picture outdo Nature: This I have carefully avoided. So likewife in my Defcriptions, I have chofen the plaineft Words that I could find, and have always related with all poffible exactnefs meer Fact; leaving it to Perfons of more Learning, and greater Capacity, to cultivate this Part of Natural Hiftory; which I am perfwaded may be improved to the Glory of our great Creator, and very much conduce to the Benefit of Mankind.

Thro' the whole Courfe of my Obfervations, I have not met with one Infance, that gave me Reafon to doubt of Infects, in general, being produced by Animal Parents of the fame Species. In this I am confirmed by the curious Experiments and Obfervations of Francifco Redi, an ingenious Italian, who writ a Treatife on this Subject: Tho' I cannot help admiring how fo exact an Obferver of Nature could be led into fo great a Miftake, as to think that fome Infects were the Product of thofe Vegetables in whofe Excrefcences they had been nurs'd up; fince it will be evident to any one who will take the Trouble carefully to examine it, that a Fly's piercing the outer Skin, or Bark of a Plant, and laying her Egg within it, fo alters the Texture of the wounded Veffels, that the Sap paffing thro' them forms the Excrefcence; which ferves not only as a convenient Matrix, or Neft, but likewife affords proper Nourifhment to the $W_{\text {orm }}$, when it is hatched, 


\section{$P R E F A C E$.}

Gatched, while it continties in that State; and proves a Security to it while in its aurelia-State, 'till it becomes a Fly; which then makes its way thro' it, tho' never fo thick: which is very much to be admired, confidering the Smallnefs of fome of thefe F/ys, and the Thickners and Solidity of the Excrefcences they are bred in. This is eafly obferved in the common Gall, in which, if there is no hole, you will certainly find a dead Infect, either a ftarved Worm or Fty, according to the State it was in, when the Gall was gathered; but if there is a hole, the Fly had acquir'd its Perfection and is gone.

No one, who is at all converfant in thefe Inquiries, can avoid admiring, and adoring the infinite Goodnefs of God, who in his Providence has given an Inftinct to all his animal Creatures, even of the loweft Order, fufficient to direet them in all Things neceffary for their own Prefervation, and Propagation of their Kind: To this end they do not lay their Eggs loofely, fo as to be driven from Place to Place, (much lefs from Country to Country) by the Winds; but fix them on Plants or Infects, \&c. which will be proper Food for their $W$ orms, while in their growing State; and thofe that are laid only fuperficially on Plants, are faftned by a Glew, fo tenacious that the Rains can't wath them off: And as for thofe that are laid contiguous, they are not laid in a heap, but in exact Order, and fo difpofed, that one may not hinder the Worm of the others from coming forth: And what is very remarkable in fome of them, a determined Side, or End, is always placed outward.

Some few of the Moth Kind I have obferved to featter their Eggs with a feeming Carelefsnefs as they fly; thefe are rarely feen. but in Meadows, and the Food of their Caterpillars, being generally Grafs, is more obvious than that of thofe which affect particular Plants: And if I may judge of the Number of their Eggs, 


\section{$P R E F A C E$.}

by the Size of them, in Proportion to the Bignels of the Fly, it is likely they lay three or four times the Number of $E g g$ s that others do, who place them with more Care; fo that there is abundant provifion made for thofe Accidents which may befall them. It would be almoft endlefs to mention thofe Obfervations only, that fall in every one's Way, who has made any confiderable Progrefs in thefe Matters.

As Providence, is fo remarkable in the Propagation and Prefervation of Infects, fo are they by no means to be efteem'd ufelefs Creatures: for befides their Subferviency to one another, they likewife ferve as Food to many other Creatures, both Fiffs and Fowls; young Birds are almoft generally fed with them; and for that End, it is obfervable that they are to be found in greateft Plenty in the Spring, which is the breeding Seafon for moft of the Volatile Kind. By this Means they become ferviceable to Mankind. Nor do they ferve us only fecondarily, but we are indebted to them for Relief in feveral Difeafes; for all our Honey, Wax, Silk, Beft Scarlet, \&c. But as thefe Things fall under every one's View, I thall pafs them by, with only mentioning, co recommend to your Notice their infinite Variety, in Shape, Texture, Colours, and the exact Uniformity that is always preferved in each Species; that you can't fee a Spot that is remarkable, but it is found in all of the fame Kind; and that the Colours, particularly of the Moths and Butterflys (which to our Eyes feem as Duft) if they be examined by a Microfcope, every Particle of them is a perfect Feather, and is placed in the Wing in moft exact Order. From the whole we cannot but conclude that they are the Work of Infinite Power, and not the Effect of meer Chance, or the Product of Corruption. 


\section{T H E}

\section{NAMES of the SUBSCRIBERS.}

Her Royal Higbness the Princess of W A L E S.

A.

THE Right Honourable the Con"nt1 efs of Anglefea.

The Right Honourable the Lord Afhburnham.

John Acton, Efq;

Robert Antrobus, $A . M_{3}$

B.

HIS Grace the late Duke of 11 Beaufort.

Her Grace the late Dutchefs Dowager of Beaufort.

His Grace the prefent Duke of Beaufort.

Her Grace the prefent Dutchess of Beaufort.

Her Grace the Dutchefs of Bedford. Her Grace the Dutche's of Buckingham.

The Right Honourable the Lord Bruce.

The Right Honourable the Lady Blighe.

The Right Honourable the Lady Lucy Booth.

The Lady Bickerftaff.
The Honourable Mrs. Bromley:

Brooke Bridges, Efq;

Robert Briftow, E/g;

Henry Booth, of the Middle-Temple, Efg;

William Byrd, of Weftover in Virginia, $E \int q ; F . R . S$.

Thomas Blencowe, of the Inner Temple, Efg;

John Philip Braine, of Dantzick, $M . \mathcal{D} . F . R$ S.

Mrs. Bovey, of Flaxley.

Mrs. Sarah Elizabeth Bridges, of Soho Square.

Mrs. Elizabeth Bridges.

C.

HIS Grace the Duke of Chandois. $I$ The Right Honourable the Countess of Coventry.

The Right Honourable the Earl of Cardigan.

The Right Honourable the Countess of Cardigan.

The Right Honourable the Lady Elizabeth Compton.

The Right Honourable Dorwager Lady Capel. 


\section{The Names of the S U B S C R I B E R S.}

The Rigbt Honourable Worfley Lady Carteret.

The Honourable Colonel Churchill.

The Honourable Thomas Cook.

The Honourable Vice-Chamberlain Cook.

Thomas Cowllad, Efq;

William Cholwich, of the Middle. Temple, Efq;

Courteney Croker, Efq;

John Cook, Efg;

Henry Cartwright, ESa;

Mrs. Elizabeth Coddrington.

Mrs. Ermin Cartwright.

D.

HIS Grace the Duke of Devon11 thire.

The Right Honourable the Earl. of Derby.

The Right Honourable the late Countefs of Derby.

The Lady Drake.

Sir Matthew Dudley, Bar. F.R.S.

Mountague Gerrard Drake, Efq;

Charles Dubois, Efg; Treafurer to the Honourable Eaft-India Compa$n y$, and $F . R . S$.

George Dafhwood, Efq;

The Reverend William Derham, Canon of Windfor, and $F . R . S$. Mr. Jofeph Dandridge.

\section{E.}

THE Rigbt Honourable the Count1 ess of Effex.

F.

THE Right Honourable the Lord Foley.

Sir Andrew Fountain, Vice-Chamberlain.

Thomes Frankland, Efq;

HIS Grace the Duke of Grafton. Grafton.

The Right Honourable the Lady Mary Gore.

The Right Honourable Dowager Lady Gerrard.

The Honourable Mrs. Grevile.

Kendrick Grantham, Efq;

William Gibbons, $M$. $\mathcal{D}$.

Mr. Edward Green, Surgeon.

Mrs. Gorges.

Mis. Mary Goopye.

H.

HEwer Edgley Hewer, Efq;

Mrs. Elizabeth Hewer Edgley Hewer.

Sir David Hamilton, Pbyfician to the Princess, and F.R.S.

Ambrofe Godfrey Hankwifius, Chimicus.

Miss. Etheldred Hovel.

Mrs. Herbert.

Francis Hawes, Efq;

John Hardy, Efq;

James Hallet, Efq;

Mrs. Howland.

Mr. Adam Holt, Gardener.

I.

THE Right Honourable the Earl 1 of llay.

The Lady Jekyll.

Edward Jackfon, of the MiddleTemple, Efq;

Charles Jernegan, $M$. D . 


\section{The Names of the S U B S C R I B E R S.}

Meffieurs William, and John Innys, of London, Bookfellers. Fourteen Books.

Erneft Auguft Jager, Efg; Apothecary s Majefty. to $\mathrm{Hi}^{\mathrm{i}}$

\section{K.}

HER Grace the Dutche ss of Kent.

II The Honourable F. C. Kreienberg, Refident from Hannover.

Robert Keck, late of the Inner-Temple, Efq;

Mr. Gilbert Knowles.

Mr. Thomas Knowlton, Gardener.

\section{L.}

UER Grace the Dutchels of Leeds.

H The Right Honourable Lady Ifabella Leigh.

The Honourable Brigadier John Langftone.

The Honourable Dacre Barrett Lennard, Efq; $F . R . S$.

Sir Thomas Lee, Bar.

William Le Grand, of Maiden Ear-

ly in the County of Berks, $E \int_{q}$;

Richard Lydal, Efq;

Francis Lynn, Efq;

$M r$. John Henric Linch, of Leipfick, Apotbecary, F.R.S. $M r$. James Leman. Mrs. Lambert.

M.

THE Right Honowrable Antony 1 Lord Vifcount Montague.

The Rigbt Honourable the late Lady Maniell.

The Right Honourable the late Lady Marrow.

Richard Mead, M. D. F. R. S. Mr. John Maud, Chymift.
Mr. John Marfhall, Maker of Optick Glaffes to His Majefty at the Archimedes in Ludgate-Street.

N. IIER Grace the Dutchess of New-

Her Grace the Dutchess of Norfolk. The Right Honourable the Countess of Northampton.

Dr. Nap.

Mr. Robert Nichols, Apotbecary. Mr. Richard Newton, Stationer.

O.

HER Grace the Dutchess of OrMr. Orbel, Mafter of Mufick.

P.

IIS Grace the Duke of Portland. II Her Grace the Dutchefs of Powis.

The Right Honourable the Earl of Pembrook.

The Right Honourable John Lord Percivale, F.R. $S$.

Uvedale Price, Efg;

$M r$ John Price, of $W$ andfworthHill in the County of Surry, Architest.

R.

THE Rigbt Honourable the CountThe Honourable Brigadier Ruffell.

Thomas Robe, Merchant.

Dr. Richardfon.

Richard Richardfon, Gent.

Mr. Thomas Richardfon, Apotbecary in Alderfgate-Street.

Mr. Ifaac Rand, Apothecary, F.R.S. Mirs. Mary Read. 


\section{The Names of the S U B S C R I BERS.}

S.

THE Right Honourable the Earl

The Right Honourable the Countefs of Scomberg.

The Right Honourable the Connte's of Salisbury.

The Right Honourable the late Count$e$ s of Suffolk.

The Right Honourable the late Lord Stamford.

The Right Honaurable the late Lord Somers.

The Right Honourable the Lady Stuart.

The Right Fionourable the late Lady Elizabeth Somerfet.

The Right Honourable the Lady Athur Somerfet.

The IJonourable Mrs. Ann Somerfet.

TheH Honourable Colonel Schutz's Lady.

The Honourable Edward Southwell, Efy;

Sir Simeon Stuart, Bar.

Sir Hans Sloane, Bar. Pr. Col. Med. and F.R.S.

Sir Edward Smith, Bar.

Auguftus Schutz, E $\int q$;

Richard Seabright, $E \int q$;

William Sherard, L. L. D. F.R. S.

John Smith, Gent.

John Shepherd, Mercbant.

John Stanhope, of Eccleshill, Yorkfhire, Efq;

Mrs. Margaret Sabins.

$M r$. John Smith, at the Archimedes in Ludgate-Street.

T.

THE Right Honourable the Earl of Thomond.
The Right Honourable the Countess of Thomond.

The Right Honourable the Lord Trevor.

The Right Honourable John Lord Vifcount Tyrconnel.

The Right Honourable the Marquis of Tullibardine.

The Honourable Mrs. Thynn.

Thomas Trevor, Esq;

Don Bruno Tozzi, Procuratore generale della Congregatione di Valombrofa E F. R.S.

Mr. Richard Tilden, Apotbecary. Mrs. Dorothy Trotman.

\section{V.}

THE Reverend Dr. Uvedale, at Enfield.

\section{W.}

THE Right Honourable the Earl of $W$ arrington.

The Right Honourable the Countess of Windfor.

The Honourable Lady Webb.

The Lady Winter.

Edward Webb, of Grays-Ini, Efq;

Thomas Windham, Efq;

John Ward, Efq;

Arthur Weaver, of the Inner-Tem ple, Efq;

John Woodward, $M$. V. Profeffor of Pbyfick in Grefham-College, Fellow of the Royal College of Pbyficians London, \&ु F.R.S. Mrs. Weld, of Lulworth-Caftle, Dorfethire. 


\section{T O}

\section{HER ROYAL HIGHNESS}

T H E

\section{PRINGESS OF WALES.}

Moft Illufrious Madam,

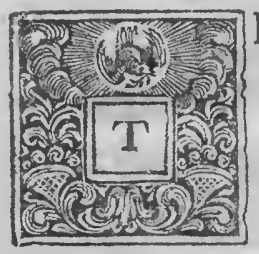

$\mathrm{HE}$ great Benefits which I have received, not only from the Prince, but alfo from Your Royal Highnefs, oblige me to take all Opportunities of fliewing my fincere Thankfulnefs for the fame; and having nothing at prefent better to offer, I have prefumed (having the Favour of Your Leave) to lay thefe Notes at Your Feet; hoping they will not be unacceptable to Your Royal Highnefs, by reafon they are Obfervations of fuch Matters, as I have the Honour to know You are pleafed with the Contemplation of, and have a great Knowledge of, I mean the Works of the Creation; a beautiful and curious Part of which the Infert-Tribe is, as well as other: of the more magnificent and admired Works: All which Works, as they, are manifeft Demontrations of the Infinite Power, Wifdom, and Goodnefs of the Great Creator and Contriver of them; fo with great Pleafure and Satisfaction have I been an happy Witnefs of Your Royal Highnefs's Juft and Pious Reflexions upon, and Celebration of the great Author's. Praifes, from Your View and Confideration of then.

TH A T the fame Infinite Being You fo juftly admire and religiounly: adore, may take You and Your Illuntrious Family under His perpetual Care and Benediction, is the daily Prayer of,

May it pleafe Your Royal Highnefs,

Your. Moft Thankful, and

Obedient Humble Servant;

W. DERHAM. 


\section{T O T H E}
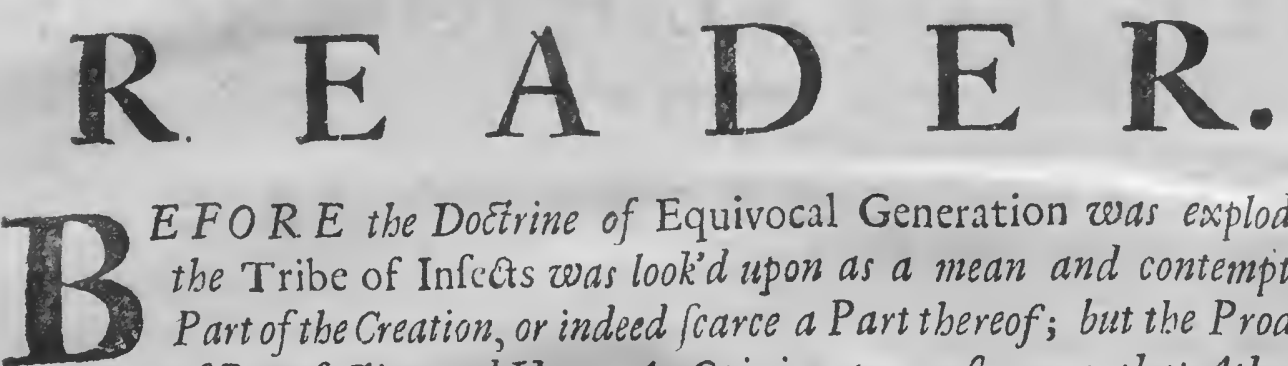

EFORE the Doctrine of Equivocal Generation was exploded, the Tribe of Infects was look'd upon as a mean and contemptible Part of the Creation, or indeed fcarce a Part thereof; but the Product of Putrefaction and Heat. An Opinion as monfrous, as that Atheiftical Notion of Chance. 'But, if we confider the Elegance and Beauty of the Colours that adorn fome of this Tribe; the Structure of the Bodies of them all nicely adapted to their Way of Life; the different States of their Generation, and what indulgent and exact Preparations are made for their Suftentation and Prefervation in each of the es States, with Multitudes of otber Things obfervable in the Infect-Tribe; I say, if we confider thefe Things, we cannot but difcern the Contrivance and Workmanhip of an Infinitely Wife and Beneficent Being. And Mr. Albin baring taken great 'Pains in the fe Matters, and bis Draughts exceeding moft- that are Extant, and bis Defcriptions and Obfervations of their Generation being faithful, $I$ thought it worth the Expence of fome of my leifure Hours, (at the Requeit of fome of my Friends) to give an Account of my owen and others Obfer-: vations, upon fuch of Mr. Aibin's Species, as fell under my Own, or their Notice: Which Province I was the more willing to undertake, to encourage. and promote the Refearches of the Curious in this Part of the Creation; wobich is one of the leaft known of any that is familiarly converfed with.

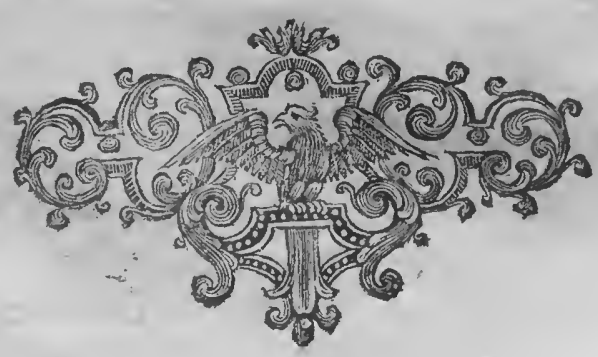




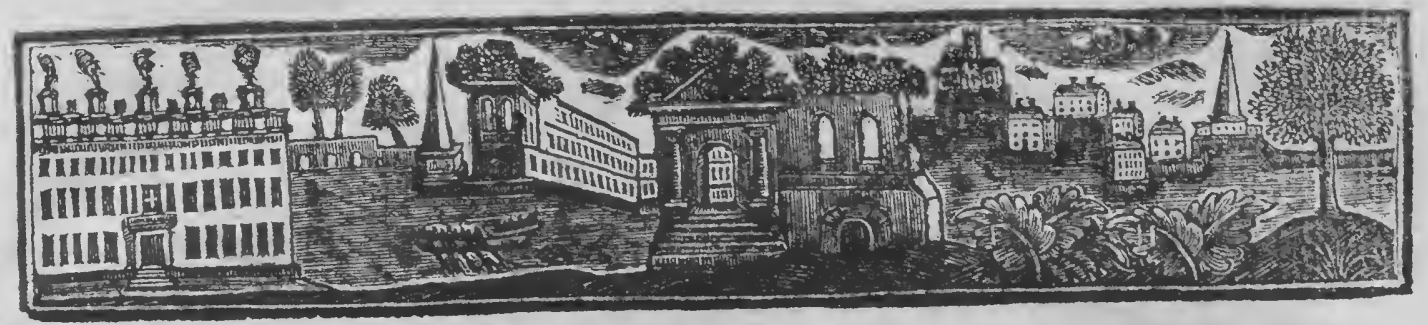

\section{Mr. DERHAM's}

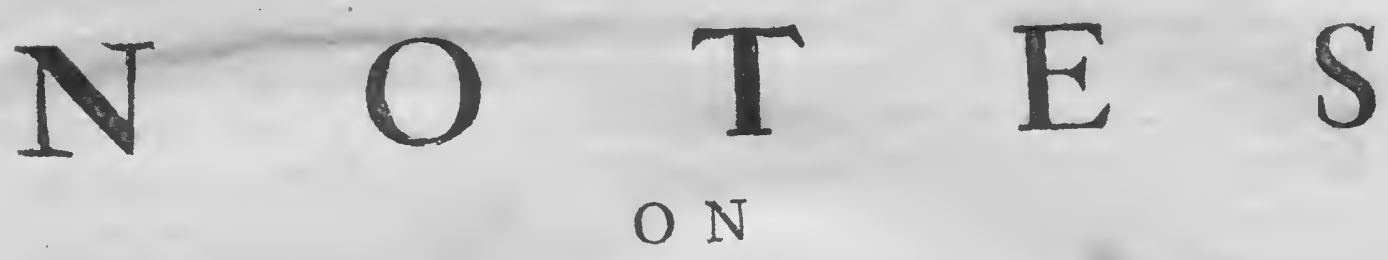

Mr. $A L B I N$ 's HIS T OR Y

$\mathrm{O} F$

\section{ENGLISH INSECTS.}

In the Defcription of P I A T E I.

FIN 8. After Month, Note I. Goedartius takes Notice, That this Butterfly hath two Seafons for its Transformation; that if it lays its Eggs in the Summer Tine, its Changes are foon effected; but if in the Autumn, it continues in the fame State till the following Summer.

Lin. Ix. After called, Note 2. Mr. Petiver calls it by this Name; or, The Greater White Cabbage Butterfy. Mufaum, No 825. Mr. Ray calls it Papilio Braffacria major vulgatifima, Hiftor. Infect. p. I 13 .

Lin. 17. After Nine-pin, Note 3. And the fame Make have all the Tribe of Butterfies and Moths; and not only they, but all or moft other Flying Infeits; fo that it is eafy to diftinguifh, by thefe Means, the Male from the Female.

Lin. 24. After Sides, Note 4. Goedartius makes this Sort of Generation a very ftrange Thing; Mira (faith he) imo vix credibilia, aut antè audita, expertus fum. But a careful Obferver may meet with frequent Inftances of this Production in the Bodies of Caterpillers and their Aurelia. Of which Mr. Albin hath taken Notice of divers in thefe following Tables, fome of one Sort of Flies, fome of another; but moft of them are of fome or other of the Ichneumon Fly-kind. Of whofe Generation I have taken particular Notice, in my Phyfico-Theolog. Book VIII. Where I have fhown what a great Variety of Subjects thefe Ichneumons make ufe of to repofit their Eggs; what a commodious Apparatus they have for this Service, and what 2 Power they have to make even Nature itfelf to be Affiftant to their Generation.

A PLATE 


\section{[2] \\ P L A TE II.}

TIN.II. AfterVeins, Note I. Mr. Ray calls it, Papilio alba nervis alarum nigris,

Brafscaria majoris figura \& magnitudine. And faith, His notis ab omnibus nobis cognitis facilè diftinguitur, Hift. Infect. p. I 15 .

Lin. 21. After Branch, Note 2. Moufet faith, Ex Chryfalide oritur auro illita.

Lin. 23. After Butterfly, Note 3. This Butterfly Mr. Ray calls, Papilio prdcox Julphurea, five flavo-viridis, fingulis alis fingulis maculis ferrugineis notatis; and Mr. $P_{\ell-}$ tiver, Papilio Sulphurea. The Wings of this Butterfly, if carefully view'd, have many fmall reddirh Spots fprinkled on the outer Edge of the Wings, efpecially on their under Side. Mr.Petiver caught the Male and Female in their Coit, and obferved the Male to be of a paler Yellow, and calls it Papilio fulphurea pallida.

$$
\text { PLATE III. }
$$

T 1N.13. After Lenves, Note I. Goedartius takes Notice, That this and other 1 Caterpillers, before their Change, purge themfelves. Upon which Dr. Lifter obferves, That the Caterpiller-State ferving to enable the Animal to live upon a different Food, which in the Butterfy-State it cannot eat, therefore it is altogether agreeable to Reafon, that the Caterpiller fhould empty itfelf of all its old Food, before it betakes itfelf to another Diet. And more than all this, he is of Opinion, That the Metamorphofis of a Caterpiller is not barely fuperficial, but made throughout the other Parts alfo; as of the Guts, as well as Mouth, and outer Parts.

Lin. 16. After called, Note 2. Came a moft beautiful Butterfly, called by Mr. Ray, I'apilio major Nigricans, alis Maculis rubris \& albis pulchrè illuftratis; by Mr. Petiver, Papiliv major nigrefcens triculor, circulo fere Janguineo ornata. Mufxum. $N^{\circ} 327$. Or the Admiral.

\section{PLATE IV.}

TIN. 4. After Brown, Note I. This Caterpiller is well defcribed by Mr. Ray, L in his Hift. InfeEt.p.347. $\mathrm{N}^{\circ} 17$ and 123 , where it is called Eruca major nigra, guttulis albis irrorata, \& Spinulis nigris per totum corpus obfita.

Lin. 11. After Liquor, Note 2. Goedartius faith, That when the Butterfly firft came forth of its Aurelia, its Wings were like Wet-Paper, and that fome watry Drops fell from them; but that in half an Hour they expanded, became dry, and were fit for Flight. And in all Probability, the Drops, which Mr.Albin takes Notice of here, to fall from the Mouth of the Caterpiller, are of the fame Nature, and for the fame Ufe. And fuch a watry Subftance I having obferv'd, with its great and neceffary Ufe in the Papilionaceous' Tribe, imagine it to be found in all,both the Diurnal and Nocturnal Kinds. The Ufe of which is for the Expanfion of the Wings; which when moiftened with this Juice, will be expanded in half an Hour; but will never be completely opened, but continue ruffled up, if they are deprived of thisLiquor.

Lin. I8. After Caterpiller, Note 3. Mr. Ray defcribes this Caterpiller under the Name of Eruca nigra, feu pulla Setigera Urticaria. Moufet faith, That the Briftles 


\section{[3]}

of this Caterpiller wound with a fmall Touch, which at firft excites a pleafant Itching, but foon after a venemous, and at laft a Pain fcarce to be endured; and that fome affirm the Mifchief hereof to furpafs that of the Pityocampe (which is a venemous Eruca bred in the Pine, mention'd by Pliny and Diofcorides, for its venemouts Bite.) Goedart calls it Helluo, from its Voracity.

Lin. 27. After Animal, Note 4. Mr. Ray calls this Butterfly, Papilio Urticaria vulgatifima, rufo, nigro, carulen, \& albo coloribus varia. And obferves, That the Male hath only two white Spots in its Wings, that is,one in each Wing, near the extreme Point of theWing; and that the reft of the Spots in the anterior Edges of the upper Wings (intermix'd with the black ones) are in the Male yellow, but in the Female white.

$$
\text { PIATE. V. }
$$

IN.ult. After Author, Note I. Mr. Petiver hath figured this Moth in his Ga1 zophylacium Natura \& Artis, Tab. II. $N^{\circ}$ II. who calls it, Papilio minor fupernè fufca, inferni viridis. He thinks it fomewhat rare.

\section{PIATE. VI.}

I IN. ult. After Author, Note 1. Merion hath both this Caterpiller and Moth, Tab. XXV.

$$
\text { - Plate Vili. }
$$

IN. 5. After Black, Note 1. Goedartius thinks this Horn is poifonous; with which it defends itfelf, when any thing toucheth it, by ftriking with the hinder Part of its Body. And in the fame Manner moft of the aculeated Caterpillers endeavour to defend themfelves when any thing annoys them.

Lin. 10. After Chryfalis, Note 2. Moft, if not all Caterpillers, when they firft come out of their Eggs, are very fnall; but by their Feeding, grow larger and larger: For which Reafon, it is neceffary they thould change theirSkin divers tintes,as Mr. Albin here obferves. The Mechanifm of which I have obferv'd is this; That the Skin of fuch Animals as change theirSkin, being not of a lax, ftretching Texture,but compact and clofe, becomes therefore too ftrait and unfit for the Body, as the Animal grows in Bignefs: And by the gradual Increment of the Body, is as gradually loofen'd from the Body, by reafon it is not capable of being extended as the Body is. And fo very exact this Shifting of the Skin is, that not the chief Parts and Members of the Body alone are denudated, but alfo the very Antenna, yea every Hair or Briftle in thofe that are hairy: And in this Change of their Skin, thofe Agitations of the Caterpiller are remarkable, fpoken of in Plate LV. Note 1.

Lin. 19. After Perfection, Note 3. I prefume that the Moth that laid thefe fixty Eggs,ivas not one that Mr.Albin had hatch'd,unlefs it had the Company of the Male. For all fuch Eggs as were laid by any of the Papilionaceous Tribe, without the Coit of the Male, I have obferv'd (as far as I could take Notice of it) to be effete, grow dry, and come to nothing; altho' indeed Goedart, $\mathrm{N}^{\circ} 78,86$. tells an odd Story of a monftrous Generation, in which an unufual Animal came out of a Caterpiller, and 


\section{[4]}

at the Time of its Death laid many live Maggots. 'This Dr. Lifter noteth to be very odd, and faith that he kept a Butterfy in a Box, which laid Eggs that produced Young. But he doubts whether it had not affociated with the Male; and no doubt but it had done fo, and thät Goedart's Animal had been Fly-blown by fome Ichneumon or other Fly, which he took no Notice of. But of this fee more in Tables LXXXIX, XC.

Lin. 21. After Ichneumon, Note 4. There is a great Variety of the IchneumonFlies; but this here figured is of the largeft Sort, and is frequent in the Summer Months about green Hedges, dry Banks, and other Places, frisking its Wings and Tail by way of Ovation, or, as if pleafed, with Fruition or Expectation. And as the whole Tribe of Ichneumon-Flies are extremely venemous, and will make ufe of every Thing that can be a convenient Matrix for the Hatching its Eggs; fo in all Probability this Frisking is a Venereal Act. Concerning the Generation of many of the Species of the Icbneumon-Flies, the Diftinction of their Sexes, Parts of Generation, Gc. the Reader may, if he pleafes, confult my Phyfico-Theol. Book VIII. Chap. 6.

\section{PLATE VIII.}

1N. 4. After Tail, Note I. This Horn, Goedartius faith, is venemous, (like that in the preceding State) and that the Caterpiller defends itfelf with it, by a quick round-about Agitation every Way, endeavouring to ftrike with its Horn what foever offends it.

Lin. 29. After EScape, Note 2. Moufet calls thefe Caterpillers, Laitucarie, becaufe he found them delighted with Lettuce. Goedartius faith, That thefe Caterpillers are Male and Female; that the Females are lefs beautiful, and want the round Spots, which are like Eyes. In all Probability then, thefe two Caterpillers here defcribed by Mr. Albin, were Male and Female.

PIATE IX.

IIN. 6. After Caterpiller, Note I. There are feveral Things taken Notice of by Goedartius concerning this Caterpiller, viz. That it can turn about its Probofcis, or tapering tharp Head, with great Agility and Quicknefs every Way, up and down this Way and that Way, as the Elephant doth his Probofcis; whence he gives it the Name of the Elephant. That when it hath eaten its Food, it draws and hides its Head within its Body, as Tortoifes do. That it is very timorous, and whenever the leaft touch'd, that it feems fo aftonifh'd, and trembles in fuch manner, as to excite the like Paffions in thofe that behold it. That it is extremely quick of Hearing, and is affrighted at the leaft Noife, and contracts itfelf immediately. And whereas Mr. Albin obferv'd them to make their Cafe to lie in, by fpinning it with Ladies Bed-Atraw, Goedort makes it fomewhat more artificial; namely, That it joined Bits of Wood, and Vine-Leaves together, with a Glue that was in its Mouth, (no doubt the fame with which it fpun, or join'd the Ladies Bed-ftraw together) and therein lay from September to the 16 th of April following: And whenever he touch'd it (lying in its Cafe) he found it as cold as Ice, notwithftanding the 


\section{[5]}

ftrong Motion of its Body at that Time. Goedartius thinks it worth Obfervation, that this Animal could live from September 4. to April I6. without any Food; and judiciouny enough refolves it into their Reft, their Coldnefs of Conftitution, and the Tenacity and Vifcidity of their Blood: By which Means, as there is no Wafte or Decay, fo there needs no Recruit of the Body; and this is the Cafe of many: Animals. Of which the Reader may confult my Phy. Theol. Book IV. Chap. I 1.

$$
\text { PIATE } X \text {. }
$$

I IN. 20. After Tab. VII. Nute 1. See the Notes on Tab. VII.

$$
\text { PLATE XI. }
$$

IN. I. After Caterpiller, Note I. Aldrovand hath pretty well defcribed this 1 Caterpiller, altho' with fome little Difference, in Lib. II. de Infect. c.4. Mr. Ray defcribes it under the Name of Eruca bicauda elegantiffma.

Lin. 23. After Auguf, Note 2. Goedartius fays, that as foon as this Caterpiller hath finifh'd its Day's Eating, it then draws its Head into its Body, (as the Iortoife doth) and there hides it, to prevent its being injur'd by the cold Air of the Night, or by Rain.

Lin. 25. After Matter, Note 3. This glutinous Matter makes their Cafe fo hard, that altho' made of comminuted Fir, or Willow, yet is it of fo great an Hardnefs, that it is farce capable of being cut with a Knife; as Goedart takes Notice of, and I myfelf have alfo obferv'd.

Lin. 43. After Moth, Note 4. The Moth he calls, Phalcna major pulcherrima, alis amplis, exterioribus cinereis maculis aut lineis nigris eleganter depiztis.

$$
\text { Plate XII. }
$$

1N. 31. After Cafes, Note 1. Aldrowand fpeaks of fome Silk-Worms Cafes, that are as big as a Man's Head; and hath given a Figure of one fent him by the Great Duke of 'Tufcany, as big as a Man's Fift, Vid. Aldrow. de Infect. Lib. II., Cap. 6. and paralip. p. 762 .

\section{PLATE XIII.}

TN. 13. After Catertiller, Nore I. Mr. Ray defcribes this Caterpiller under the Name of Eruca verbafcum depafcens cinerea pulchrè variegata.

Lin. 24. After Moth, Note 2. The Moth Mr. Ray calls Phalana media, alis. exterioribus cinereis, lineis ơ maculis nigris variè depiztis, Tapji Barbati.

Lin. 27. After $m$. Note 3. As it is before thown, that the Ichneumon-Flies are very greedy of laying their Eggs in Caterpillers; fo many others have the fame Propenfity alfo; particularly Flefb-Flies; of which Sort this Fly in the Table is. And. as the finooth Caterpillers, or fuch as have but a thin Armature of Briftles, are the moft expofed to the Luft of thofe Flies, fo they are what are the moft commonly FlyBlown. 


\section{[6] \\ PLATE XVII.}

IN. 5. After Grafs, Note r. This Caterpiller, Goedartius faith, he obferv'd

to be fleepy in the Day-time, and always at Reft; but in the Night to be brisk, and in perpetual Motion.

\section{Pzate XX.}

IN. 1. After Caterpillers, Note 1. Mr. Ray defcribes this Caterfiller under

the Name of Eruca denfius pilofa magna, pilis longifJmis incanis, fulvis $\&$ nigris varia, cum punctorum albentium lineis annularibus, Hift. Infect. p. 152.

Lin. 5. After it, Note 2. If this be Goedart's 99 th, it not only rolls itfelf up, but erects its Brifles as the Hedge-Hog doth; and lies fo ftill, that it fuffers its Briftles to be pull'd off, rather than it will ftir. He takes Notice alfo, That Sparrorvs and other Birds will not eat them, but rather abhorr them, which hath caufed fome to think they are poifonous to thofe Birds : But in all Probability, it may be the Stiffnefs and Roughnefs of the Briftles, that caufeth this Abhorrence.

Lin. I3. After Moth, Note 3. Mr. Ray calls this Moth, Phalona major, alis amplis oblongis, albicante \& fufco coloribus pulcbrè variegatis, interioribus rutilis cum 'maculis nigris, Hitt. Infect. p. I $5 \mathrm{I}$.

\section{PIATE XXI.}

IN. ro. After Moth, Note I. This Moth is that which Mr. Petiver hath 1 figured in his Gazophylacium Natura of Artis, Tab. XXXIII, xii. under the Name of Phalana nigrefcens maculis majoribus Jubtus flavefcens: Or, The Tellow Royal Leopard.

\section{PL ATE XXII.}

IN. 24. After $W e b$, Note I. 'The Hair of this Sort of Caterpillers is of great 1 Ufe to them, both as a Guard againit voracious Birds, and other Animals; as alfo in the Making their Cafes or Webs. Of which fee Tab. LXXXIII.

\section{PI A TE XXIII.}

L IN. Ir. After Moth, Note I. Mr. Ray defcribes this Moth under the Name of Phalana media, antennis tenuibus, capite, facie, of oculis Noctua, fulvis, alis oblongis ex rufo cinereo, fulvo \& albicante variis, Hitt. Infect. p. I62.

\section{PIATE XXIV.}

I IN. 8. After following, Note I. Guedartius very judicioufly and truly obferves, that this Caterpiller, Defectu alimenti ad quietem $\circlearrowleft$ tranfmutationem Se componit, $\sigma$ ${ }_{24}$ Septembris mutari copit; jed quia jam autumnale frigus appropinquabat, \& Flores quibus pafci Jolent Papiliones, deficiebant, manfit in transmutatione ac quiete fua ufque ad $\mathbf{I}_{3}$ Junii Sequentis anni. And for thefe two Reafons moft of the Papilionaceuns Tribe do, in good Seafon, betake themfelves to their Aurelia-State, viz. When the Vegetables (in which they delight) either fail, or become dry, and unfit for their 


\section{[ 7 ]}

Food; or elfe when the Winter-Cold approaches, which few Infects can bear. And an admirable Provifion this is for the Prefervation and Safety of thefe Creatures: Concerning which, the Reader may confult Phyfico-Theol. Book VIII. Chap.5.

Lin. 28. After Diffembler, Note 2. Goedart faith, Eruca hac admodum meticulo $\int_{a}$, ideoque ad fimulationem prona. Simulac enim attingitur, corpus fuum aritè in orbem convolvit, immotaque manet, inftar mortua, etiamfi de loco in locum toto corpore verfetur \& agitetur; Sed fivehementius prematur, fimulare amplius non poteft, Sed Hypocrifin Juam prodens variis modis commovetur, ut effugiat, Lifter's Goedart, $N^{\circ}$ 96. Mr. Ray defcribes this Caterpiller under the Name of Eruca birfuta, medice magnitudinis, nigra, cum linea in medio dorfo rubra, Hift. Infeet. p. 346.

\section{PIATE XXV.}

L IN. I. After Caterpiller, Note' I. Thefe Caterpillers are fo ravenous, that Madam Merian faith, that Deficieinte pabulo, fibimet ipfis invicem Efca fuere. And it is not improbable, but that the Ejection of the Liquor here mention'd, may be to pall the Appetite, or fome Way or other elude its voracious Enemy.

Lin. 21. After other, Note 2. There are two Things in which the Male and Fcmale Moths differ, which may be obferved from the two Moths before us. r. Their Size (here taken Notice of) the Female being larger than the Male, efpecially in the Alvus, or Belly. 2. Their Antenne; in the one fmooth, in the other plumed: Which is the conftant and certain Note of Diftinction of the Sexes, not only of the Phalana Tribe, but of other Infects alfo; thofe whofe Horns are pectinated, or plumed, being always Males; thofe with fmooth Horns being Females.

\section{PLA TE XXVI.}

LIN. I. After Caterpiller, Note I. Mr. Ray defcribes this Caterpiller under the Name of Eruca major, denfius pilofa, crebi is pilorum fafciculis, ceu Scopulis aut Penicillis, denfis, rufis ornata, Hift. Infeet. p. 282.

Lin. Ir. After Moth, Note 2. Goedartius obferves, that this and the following Moth do both cover their Eyes with their Fore-Legs. Quum Se primìm vifui offerret, anterioribus pedibus oculos tegebat, quafi lucem ferre nondum valeret. Vid. $N^{\circ} 80$. And in the following $N^{\circ} \cdot 8 \mathrm{I}$. Anterioribus pedibus folet caput integrum ita contegere, ut nullo modo appareat. Mr. Ray faith, Scapula, Caput, ut \& Pedes primores (quos cum quiefcit antrorsion resta protendit, iifque oculos \& caput occultat) longa o denfa lanugine veftiuntur, Hitt. Infect. $p$. I 86 . This Moth Mr. Ray calls Ploalona media cinerer, alis oblungis, exterioribus quatuor lineis nigricantibus tranfverfis diftinctis, Ibid. p. 185 .

Linn. 17. After Horns, Note 3. This Caterpiller is by Gonfton called Enuca Antennulata in his TableXX. And Moufet faith, p. $18 \hat{7}$, Periculum vocare Joleo, quia utrinque ex fronte, atque etiam in uroprgio Peniculus erumpit mollis, colore ceracino. Of thefe Caterpillers with Tufted Backs there are feveral Sorts; fome of which are taken Notice of in fome of the following Plates. Thefe may be properly enough called Eruce penicillate, The Pencil-Caterpillers: And fuch as have pencil'd Horns, Eruco penicil- 


\section{[8]}

Late antennulata. Mr. Ray (but omitting its Antenna) hath defcribed this Caterpiller by the Name of Eruca medic magnitudinis, nigra, longis pilis birfuta, quinque medio dorfo innafcentibus pilorum longiorum scopis nigro albo of ex luteo viridi coloribus wariis, Ibid. p. I 87 .

Lin. 22. After Moth, Note 4. Mr. Ray defcribes this Moth under the Name of Phalana obfoletè cinerea, alas corpori velut circumvolvens, pedes primores longa denfa lanugine hirfutos antrorfum longisfomè porrigens.

\section{PLATE XXX.}

L IN. 18. After Table, Note I. If any of thefe Caterpillers are the fame with Goedart's, $\mathrm{N}^{\circ} 44$. they are what he faith, Ob fingularem timiditatem, meticulofam nominavi. For faith he, Simulac quippiam non confuetum fibi percipit, in terram fe pracipitem dat, inftarque mortuce quiefcit, corpore in orbem arctifimè convoluto.

\section{PI A te XXYI.}

I IN. 8. After Silver, Note I. This Muth is that which Mr. Petiver faith he Leceived from Madam Glanvil out of the Weft of England, and calls Phalana occidentalis Anglia, virefcens, lineis vbliquis albefcentibus, Gazophyl. Nat. \& Art. Tab. VII. $x i$.

\section{Pl A T E XXXII.}

IN. I. After Caterpiller, Note I. If this Caterpiller be the fame with Goedart's I. $N^{\circ}$ 3o. there are feveral Things which will deferve our Notice, I. Goedartius obferves, that this Caterpiller is fed with diversHerbs; but is very dainty in choofing them, feeding only on fuch as are frefh and green. 2. That it often changes itsSkin; and after it hath fo done, it refts a whole Day from Food,not being able to take any, by reafon of the Tendernefs of its Skin, till it is fomewhat harden'd by the ambient Air. And in the Mechanifm of the Change of the Skin, his Obfervation is the fame with mine in Plate VII. before, Nute 2. viz. Aliquoties pellem mutavit. Videtur enim adeo dura, ut corpore notabiliter aucto, eam rumpi necede fit, aliamque novam cutems fubcrefcere. Upon which Dr. Lifter very fagaciounly hath taken Notice of the fame Mechanifm in other Animals. Tale quid, faith he, in Araneis etiam obfervavi; idem etian obtinet in Animalibus, Cornua fua exurentibus, ut Cervis; qua, cum plenè maturuerint, ulteriori nutrimento privata, funt dura, $\sigma$ ab aliis fuccrefcentibus expelluntur. Idem etiam in Pilis Animalium, of Plantarum foliis, in cbfervationem venit. Nec minus certum eft fingulas pelliculas fibi mutuò Succeffive fuppullulare, ficut in Plantarum foliis. 3. Goedartius faith, Thefe Moths fly chiefly by Night, but prudently thun the Flame of Fire or Candles, different from what others are wont to do.

Lin. 7. After Moth, Note 2. Mr. Ray defcribes this, or fuch a like Moth under the Nane of Pbalana media domeftica, alis exterioribus rubro, rufo-cinereo, $\sigma$ albicante colore varios, cum tranfverfa linea albicante, imo margine laciniato. He calls it domejica, becaufe domos frequentat Julio, Augufto, \& Seprembri menfibus. Ray's Bint Infect. $p .183,184$. 


\section{[9]}

\section{Plate XXXIV.}

TIN. 18. After $g h$. Note r. Moufet, p. 97, defcribes three Sorts of thefe Ragwort Moths, differing fomewhat in their Red Colours, as alfo in their Size. And I have obferv'd alfo, that there is more than one Sort of thefe; fome being larger, with flender Antenna; and others leffer, with club-headed Horns. But I take thefe to be only a Difference of Sexes, not of Species; and that the larger (which are figured here in this Plate) is the Female; the leffer, with Club-Horns, the Male. Mr. Petiver calls this Moth, phalana umbrica linea, maculifque Janguineis, Gazophyl. Tab. XXIII. Fig. 6. Mr. Ray defcribes this Moth under the Name of Phalana media alis exterioribus colore nigro of fanguineo variis, extimo duntaxat margine nigro. The Ragwort Moth, Ray's Hift. Infect. p. 168.

\section{PIATE XXXV.}

I IN. 2. After Colour, Note I. There is no doubt but this Caterpiller is the Col'us famed for making a luxurious Difh among the old Rumans; of which Pliny faith in his Nat. Hift. Lib. XVII. Cap.24. In hoc Luxuria efe copit; pragrandefque Robonzm delicatiore funt in cibo: Colfos vocant atque etiam farina faginati, hi quoque altiles funt. But from its reddifh Colour, Goedartius calls this Caterpiller the Crab, quandoquidem cancro cocto concolor eft, faith he, atque clypeos cancrinis gerit fimiles; aliogui liceret eam Te:ýlovis, five Olentem Hircum vocitare; quoniam malè olentem, ad inftar Hirci odorem folet Jpargere. The Clypei, which Goedartius mentions, are two Plates, fomewhat refembling a Crab's Fore-Legs, which are more plainly expreffed in Goedatt's Draught, than in this 35 th Plate.

Lin. 7. After Oak, Note 2. I have taken Notice of Holes, fome of three quarters of an Inch, and fome near an Inch bore, eaten in the Timber on which the Bells in UpminfterSteeple are hung. The Timber is as firm and found Heart of Oak, as was ever feen; and there is no doubt but that thefe Holes were eaten by thofe $\mathrm{Cof} / \mathrm{f}^{\text {s }}$ when the Timber (now many Hundreds of Years old) was green.

Lin. I5. After Tiees, Note 3. 'This Appearance of the Motiss on the Bodies of the Trees they perforate, refolves a great Doubt of Goednitius, who faith, Quod ad modum attinet quo ba Erucce propagantur; is obfcurus eft, faltem miliz non fatis cognitus; imo, meo judicio, falvo meliori, non admodum facile inveftigari poteft qua ratione progignantur. Extùs enim in Arboris Ligno, nullhm foramen, nulla rima, nulla forcmina, ne quidem exigua, deprelsenduntur; of tarren intiss Enucc inveniuntur. Id igitur folummodo certum eft, bafce fape in medulla Salicum offendi, \& verofimile iftic expinguedine \& putrefactione, à calore fota, gigni, uzi multa Animalcula qua Sponte orta vocant, ex putredine, \& calore nafci folent. This Surmize about their Spontaneous Generation, Dr. Lifter very juftly denies, and judicioully affirms, Copfos hos ab Ovis, à Parentibus Animalibus exclufis, effe productos; aque etiam patet minutulos bos Vermes capaces efle Arborem gradatim terebrandi, id eft, pro alimentandi tempore, qua quidem exigua foraminula forte poft plenum corum ingreflum denuò coalefcunt, faltem non funt 


\section{[ 10 ]}

sculis, nifi Lynceis, afpectabilia. Addo infuper, quòd forfan Tranfinutationem nullarn fubeant, fed per multos annos Jub Erucarum Larva manent. Quod probe confentit cums meis Obfervationibus; qua omnia Obfervationem valde tediam reddunt, fed de veritate ejus plane certus $\int u m$. Now, if there be three Years before this Moth comes from its Egg to its Mature-State, and it is found on the Body of the 'Trees it lays its Eggs on, at the proper Seafon for their Hatching; there is no great Doubt to be made, but that what Dr. Lifter gueffes to be the Way of the Generation of thefe Colfi, is certainly in Fact fo.

Lin.21. After Growth, Note 4. It is not for the Growth, (as Mr. Albin here fuppofes) but the Expanfion of the Wings, that this Moifture is necefiary, as is thown in Note 2. on Plate 4. For the Wings are completely formed (both the Bones and Membranes) long before the Muth endeavours to break its Prifon : But this Humectation is of abfolute Neceffity to make the Joints of the Wing-Bones pliant, and the Membranes capable of being expanded by them; as is not only agreeable to Reafon, but is manifeft from the Matter of Fact related in the Note now cited.

Lin. ult. After $N^{\circ}$ 39. Note 5. Mr. Ray hath accurately defcribed this Moth, as alfo the Caterpiller, in his Hift. In ert. p. 150, 35 I.

\section{PIATE XXXVI.}

T 1N. 8. After up, Note I. I am in fome Doubt, whether this Contraction, or Shrivelling of the Wings of the Females, was not from the Want of due Moifture fpoken of in the preceding Plate; becaufe in thefe two Inftances, which Mr.Albin here takes Notice of, and in moft, if not all others that I have met with in the Scarab-kind, as well as Papilionaceous, where the Females have been defective in their Wings, it hath been from the complete Want of Wings, or that they had only a feeming Rudiment of Wings, and not from fuch imperfect and ufelefs Wings as are here defcribed.

\section{PLA TE XXXVII.}

1N. 3. After Wafer, Note I. It is with great Art and Sagacity that many Caterpillers make themfelves Cells, by folding up the Leaves of the Trees on which they feed. Their Manner is this, They roll up one Leaf round, like a hollow Cylinder, or join more together, which having brought to fuch a due Size, or Capacity, as to fit their Body, they then weave it round, and fo keep the Leaf or Leaves in their proper Pofition with this Web, which they draw from their Mouths. 'This Web they line their Cells with, and by that Means make them foft and eafy, for their Repofe; context and firm againft the Rain; and Thady and cool againft the SummerHeat ; which two latter, Goedartius faith this Caterpiller is very impatient of.

Lin. I7. After Caterpiller, Note 2. Goedartius obferves of this Caterpiller, that Semper madida eft, of fulgidum (quem limacis inftar excernit) limum, quocunque locorum folet repere, terra afficat, $\delta$ adharentem eum poft fe relinquit. Admodum etiam eft timida, metuve anxia videtur; ut plurimum $\int u b$ herba foliis occultat; frequenter etiam locum, o Aationem mutat, of tenebras diurna luce magis amat, velut Avicula, que de nocte vo- 


\section{[i1]}

lant. Semper no¿tu, at interdiu nunquam cibum capit, \& quidem in altum ereito corpore, tanquam adverfus omnem fe tueri parata violentiam. Ubi autem Serpit, velocitèr progreditur; fortean quod fibi male metuat al hoftibus. When this Caterpiller betakes itfelf to its Aurelia State, Goedartius faith, Ex arena ơ limo contexit domicilium, \& mutato colore Metamorphofin fubit. For Diftinction-fake he gives this Caterpiller two Names, viz. Quoniam Se perpetim puram, nitidamque confervare folet, Mundx nomen efto; aut fiquidem Pari infidias of ftrunt, eamque perfequuntur, $\sigma$. avide devorant, Parefcam per me licet nuncupes.

Lin. 2 I. After $l m$, Note 3. Mr. Ray very well defcribes this Moth under the Name of Phalona minor alis oblongis, ex albo of caruleo-nigricante variis, ad exortum flavis, Hift. Infect. p. 222. Mr. Petiver calls it, Phalana minor alba, maculis nigrefcentibus ornata, Gazophyl. Nat. \& Art. Tab. XXXII. 8.

\section{Plate XXXIX.}

I IN. 2. After Yellow, Note I. This is the feventh Caterpiller in Aldrovand's fixth Table, and is of that kind of Caterpillers, which are called Geometra, quod hominis Geometra ferè inftar incedendo agros dimetiantur; faith Aldrovand, de Infect.Lib.II. Cap.4. And their Way of Going, he faith, is, Undatim, parte enim innitentes triore, contrabunt $\int e \int e$, adducentes pofteriorem, arcuatimque incedunt.

\section{Plate XLIII.}

I IN. 16. After Yellow, Note r. Mr. Ray hath defcribed this Moth under the Name of Phalana media, alis amplis albis, maculis crebris nigris, of lineis tranfverfis luteis variis, Hift. Infect. p. 178 .

Lin.ead. After Moth, Note 2. The Eggs of this Moth are fmall and oval, and of a Lemon-Colour, or light Yellow. But Goedartius faith he found them green, and laid upon certain Leaves, eaque tunc pilis quibufdam aut lanugine obduci, animalculi inftar, eaque ratione à frigore tutum confervari.

\section{PL A T E XLVII.}

TIN. I. After aa, Note I. Thefe Caterpillers are of the Geometer-kind; Alierius plane forma funt (faith Goedartius) ac relique Eruca, qua pedes folent babere in medio corforis, ha vero in extremitatibus; iifque vim exercent non exiguam. Ubi locum (faith he) mutant, atque ab uno ramo in alium a cendere conantur, pedibus illum firmiter apprebendunt, corpus furfum erigunt, ferpentis inftar, eoque modo tentant, experiunturque an alium fibi locum comparare queant. Adeo tenaciter Se pedibus pradictis retinent, ut vix. à corpore cui adharent, divelli polfint.

Lin.7. After Moth, Note 2. Mr. Ray hath well defcribed this Moth, and calls it. Phalana minor alis amplis, è cinereo albicantibus, interdum fufco-cinereis, quatuor in exteriorum margine maculis linearibus è fufco nigricantibus, Ray's Hift. Infeat. p. 179. 


\section{$[12]$}

\section{PLATE XLVIII.}

IN. I. After Caterpiller, Note I. Thefe Caterpillers I have found on the Elder, $\checkmark c$. I obferved that they generally ftand on fuch Parts of the Tree, as are neareft the Colour of their Bodies: By which Means they are not eafily feen, being vesy like fome Part or other of the Tree; fome like the dead, fome like the live little Branches. Whether they have a Power of changing their Colours, like the Chameleon, I never could difcern. Thefe are of that Kind which Goedartius hath defcribed and figured in $N^{\circ}$ 10, of Dr. Lifter's Edition, only without thofe Bunches or Knots he fpcaks of. Like his, they ftand ereet and ftiff, and refemble a little Stick. To diftinguifh thefe from other Caterpillars, he faith, Licebit nuncupare, * "Exтатov, feu Extenforem, fiquidem fe rectà folet in longitudinem extendere: aut

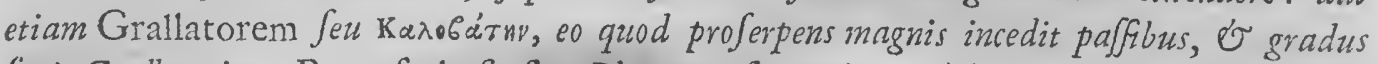
facit Grallatorios: But of thefe fee Plate 94 following. Thefe Moths are different from that which Goedartius defcribes, only the Under-Wings are pointed fomewhat like his.

\section{PLATE LI.}

I IN. ult. After $N^{\circ} 8$. Note I. The Manner how thefe Butterfies lay their Eggs,

Dr. Lifter very truly relates, as I have feen myfelf. Saith he, Papilionem, in ipfo Ova fua in Braffica folium excludendi actu, cautè obfervavi. Quod boc modo praftatur; Papilio folii margine Sedens, caudam fubter folium reclinans (extremitate Cauda folium tangendo) Ovum unum excludit, tunc alium, dein tertium, donec omnia ad libitum excluferit. Sed univer Sa hac Ova eo ip fo momento, extremis corum minoribus furfum tendentibus figuntur, non autem lateraliter excreta funt; \& poftea, calore Solis, furfum vertuntur. Mr. Ray calls this Butterfy, Papilio alba media, alis exterioribus albis, duabus maculis nigris infia mediam longitudinem, verfus interiorem marginem notatis, interioribus Jubtius flavicantibus, Hift. Infect. p. II 4 . This I take to be the fame Butterfly that Mr. Albin hath figured in this 5 If Plate, altho' Mr. Ray takes Notice but of two black Spots in the Wings, and Mr. Albin hath figured three, becaufe $I$ have feen them about Upminfer, with trvo oftner than with three Spots, and yet take them to be of the famie Species: The Female is Meriun's 39. Vol. II. Mr. Petiver gives it the Name of Papilio albus vulgaris minor, Muf. Pet. 826 . The Male he hath given a Figure of: in his Gazophyl. Tab. XLIX. Ir. under the Name of Papilio albus minor, apicibus rigris. The Lefler white Cabbage Butterfy. The Female e.f. he hath given a Figure

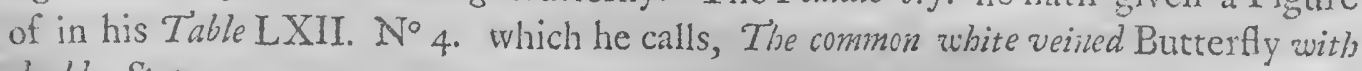
dozible Spots.

\section{PIATE LII.}

IN. II. Afier d, Note I. This Caterpiller is that which Mr. Ray defcribes - under the Name of Eruca Brafficam depafcens viridis, lineâ in utroque latere $\ddot{E}$ luteo albicante, Hitt. Infect. p. I I 4 . 


\section{[ 13 ] \\ PI A TE LIV.}

I IN. 8. After Butterfly, Note x. Mr. Ray defcribes this Butterfy, anid calls it, Papilio Ulmaria fimilis, Sed minor, alis laciniatis, interioribus lineolâ albâ incurv $\hat{x}$ notatis, Hift. Infect. p. I18. Mr. Petiver calls it, Papilio teftudinarius alis laceratis.

\section{PIATE LV.}

I IN. 8. After Chryfalis, Note I. Dr. Lifter in his Note on $N^{\circ}$ 3. in Goedartius, thus deforibes the Manner how thefe Chryfalides are fufpended in their dry and fafe Places of Retreat, viz. Hoc unico fllulo medium circumjecto praftari (nam Sapiufculè rei, dum adbuc in fieri, oculatus teftis fui.) Quod fit, priufquam appareat $\int_{u b}$ Angularis Chryfalidis forma, boc modo: Eruca caput fuum deorfum reclinans, of locum, ubi fe fufpendere vellet, tangens, filum ex utraque corporis parte figit, tranfverfim illud trabens; dein caput reducens, feque pendulo fitu ponens, vibrat agitatque feits fam, adeoque pelliculam Erucalem frangit, quâ avolente, Chryfalss apparet, ita pendens prout defcribitzin.

And Goedartius himfelf takes Notice of a great Agitation of the Caterpiller about the Time of its changing its Skin, viz. Priufquam in nove forme aflumptione veterem pelliculam exuant, aisxiè videntui laborare, corpus undiquaque quatiendo, jaltando, contorquendo, ac tremendo, Yanquami fi acut $\hat{~ f e b r i ~ c o r r i p e r e n t u r . ~ T a n d e m ~ c o r p o r e ~ a l i-~}$ quoties Jurfum fublato, ac denuo deorfum dimiflo, univerfum corpufculum funm in orbeisn contrahunt, unde adeo intumefcit, ut pellis tota in longitudinem findatur, of fic paulatim, alia nova fuccrefcente, decidat eoque tempore aliquandiu quiefcunt.

Thefe Agitations of the Caterpiller, are of great Ufe to promote the Shifting off of the old dry Skin, of which i- have given an Account in plate VII. Note 2.

There is another Thing rery odd, (if rrue) taken Notice of by Goedart, viz. Quod ubi dorfum fuit Eruca, ibi Alvus of Pedes extant ejus animalis in quod mutatur; of contra, wibi Alvus \& Pedes Eruca erant, ibi jom Tergum confpicitur Aximalis, quod per Transformationem ex Erruca produtzum fuit.

This Opinion of Goedartius Dr. Lifter differs from, faying, Chryfalis enim, mea fententia, corpus funm intra aridam laxamque Pelliculam fat commode vertere poruat, etiam in ipfo Exuvias fuas deponendi AEtu; quod Errori buic Anfam fubminiftrare polet, pracipue cum tam anxiè laboraret, atque moleftaretur in illis diffingendis, ut advertit Author.

Another Thing taken Notice of by Goedartius, is the Moifure he obferved about the Wings of this Moth when it came out of its Aurelia-State, as well as of that $N^{2}$ I. The Ufe of which I have thewn in Plate IV. Note. 2. and Plate XXXV. Note 4. Befides which, he took Notice of another Liquor, $P_{0 \text { of }}$ isac, ex $P_{G \text { a }}$ pilionis membris pafteriuribus quatuor gutta Sanguinis deciderunt; poftque mediam boram gutza lamoris clari infar aque. This Obfervation Dr. Lifler confirms from his own Obfervation, Egomet if Se Liquorem ilium rubrum decidife fapenumero obfervari; wecron of parilem etiam confpexi, tametfi colure minimi rubrum, è Muscis quamplurimis, 


\section{[14]}

ex Chrysalidibus exclufis, prodiifle. Hujus Liquoris interventu corpora fua intumescere faciunt, of Chryfalidum fuarum Folliculos refpectivè diffingunt. Hujus etiam Liquoris quedam quafi irroratio alas fuas adeo madidas redit quando primo excluduntur of prodeunt. Vide in vita Peireskii de fanguine '̀ colis pluente, quod buc relationem babet.

'Thefe red Drops I myfelf alfo have ofren met with, aitho' not fo copious, as peiresk did, who fays, That when the Country-People were in that great Fright from the Bloody-Rain, he took Notice that it happen'd about the Butterfly-time, and that there were great Numbers of Butterflies then flying thick in the Air, with other material Circumfances, that make it highly probable that the BloodyRain was nothing but the red Drops which fell from thefe Butterfites.

Of Merian's Miltake about this Caterpiller's weaving a white Web, orc. See Plate LXX.

Lin. I1. After Turtoife-fbell, Note 2. This Butterfly is defcribed by Mr. Ray, Hift. Inect. p. I18. Who calls it, Papilio Urticnrium referens major, Alis amplioribus; quam Ulmariam vocitare foliti fumus. Mr. Petiver calls it, Papilio tefudinarius major. In Englifh, The greater Tortoife-fbell Butcerly. Mufaum, No 315.

$$
\text { PIATE LVI. }
$$

1N. I. After Caterpiller, Note r. It is a pretty Story which Goedart tells of this Caterpiller's Choice of its Foud: Poftquan buic Eruce multas of varias edendas prabueram herbas, quas omnes faftidiebat, tandem Urticas appofui. Quod cum fecifem, cum maxima admiratione vidi, quam gavifam iis, of latam caput iis affricare, non fecus ac fi earum adventum gratulari vellet, tantaque oblectatione eas vorantem, ut nilit fupra. 'This Nicety of Caterpillers in the Choice of their Food, Dr. Lifter ingeniouly propofes, I. As a good Way for difcovering the Vertues of Plants. 2. To find out a proper Wood for the Sheathing of Slips. To difcover which, he advifeth, Afciata politaque quadam Lignorum Frufta, inftar Talearum Anchoris affixarum, in aquis of fuminibus, Vermibus plurimum moleftatis, ponere. Illud enim Ligni genus, quod Vermes repudiant, fumma cum ratione in ufum defignatum eligendum eft.

Lin. Ix. After Chry falis, Note 2. 'The Chryfalis, when difturb'd, briskly moves itfelf this way, and that way, as if minded to repell any thing that difturbs it. Goedart fays, $\left(N^{\circ} 5\right.$.) that the Caterpiller fix'd its Aurelia to the glafs Cover of the Box in which it was kept, Ubi attingebatur, fortiter adeo fe movebat, ó corpore Vitrum repercutiebat, ut in eo fonitum daret, quafi pulfati Tintinnabuli, tamdiudurantem,

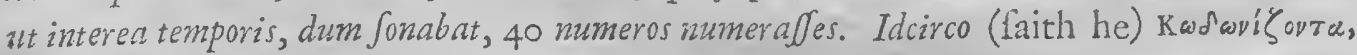
per me licet eam nuncupare.

Lin. I3. Afrer Lady, Note 3. Mr. Ray defcribes this beautiful Butterfly under the Name of Papilio major, alis amplas; exterioribus fufcis, albis, rubris maculis of lituris pulchre variegata, Hift. Infect. p. 127. This is not that which Mr. Petiver gives the Name of the Painted Lady to; but it is fomewhat like it. 


\section{[15]}

\section{PIATE LVII.}

IN. I1. After Flight, Note I. Although fuch Caterpillers as have Tails, or horny Excrefcences on their Rumps, do fometimes produce fuch Moths as fly fwiftly, yet I do not think that it is a genera! Rule that they always do fo. As for inftance, the Silk-Worm, which hath an horny 'Tail, produceth a Moth that flies but flowly and heavily.

Lin.ult. After Moth, Note 2. 'This Caterpiller is not unlike Goedart's 25 th in Lifter's Edition; but the Wings of the Moth are in this more jagged at the Ends than Goedart's. Probably both this Moth and its Caterpillar are Mr. Albin's, in Tab. VII. and defcribed by Mr. Ray in his Hift. Infeet. p. I44, I45.

\section{PLATE LVIII.}

TIN. 9. After Caterpiller, Note 1. Aldro vand defcribes this monftrous Caterpiller to bear the Figure partly of a Caterpiller, and partly of a Spider; upon which Account, he gives it the Name of 'Aeq:xvord' $\mu \pi n$, or Erucaraneus. His Defcription is, Sex primum à capite ex primis corporis flexibus pedes Araneorum pedibus fimillimos emittit; dein izterfofitis aliquot flexum intervallis, alios octo, more Erucarum, quas alioqui toto corpore refert. Tuta ex cinereo ad luteum vergit, fed Annuli coloris funt plane caftanearum, ficut etiam Pedes \& Cauda. Aldrov. deInfect. Lib.II. c. 4. I take this to be Moufet's Vermis Staphylinus, which he faith Mr. Knivet fent him the Figure of, which he faith is common in Norfolk, and is poyfonous; as he proves from an Inftance, viz. Venenatam hujus naturam ex eo didicimus, quod Equi duo, dum cum fono eas devorarent, toto corpore inflati interierunt. For this Moufet prefcribes a Remedy, which may be feen p. 198.

$$
\text { PLATIE. LX. }
$$

I IN. I. After Worm, Note r. This Grub, Goedartius faith is call'd in the Belgick, Tongue Koren-Worm, or Corn-Wurm; quia tritico multim nocet, radices ejus confumendo. As to its manner of Feeding, Goedartius faith he kept it a whole Year in a glafs Veffel with White flower'd Hen-bit. Atque obfervavi (faith he) tempore vefpertino Vermsm ex: Lagena fundo folitum fuiffe Surfum prodire, ut herba \& flore vefceretur. Hoc peraíto, denù intra terram fe abdidit; nunquain enim aut rariffine de die Supra terram asparet. Goedart. $N^{3}$ III.

Lin. ro. After Chryfalis, Note 2. As to their Change to their Aurclia-ftate, Goedartius faith, Poftquam Vermes bujus defcriptionis fatis comederunt, \& ad juftam corporis magnitudinem ac ftaturam pervenerunt, loca quarunt excelfa, ficca \& quieta, in pomariis, agris, aliifque in locis, ut tutò quiefcere poffint, atque ad Transformationem, quam expezant, Se placide componant. And afterward he faith, Antequam Vermes battenus defripti, in Molitores five Melolonthas (their Dutch Name) transformantur, annum Jupergrefj funt quartum.

Lin. 


\section{[16]}

Lin. 12. After Betle, Note 3. Mr. Petiver hath figured this Bettle in his Gazophylacium, Tab. XIX. 2. under the Name of Scarabaus arboreus major caftaneus; from its being of a Chefnut Colour. Alfo Mr. Ray calls this Beetle, Scarabaus arboreus major, Hift. Infect. p. 104. or Blind Beetle, becaufe Magno murmure o mugitu in bominum faciem involat, imo in obvium quodcunque, ac fi cacus edpet, unde Anglice proverbialiter dicitur; As blind as a Beetle. Dr. Liffer in his Appendix to Mr. Ray's Hiftory de Scarabais Britannicis, calls it Scarabaus maximus rufus, uropygio deor fum inflexo.

Goedartius is of Opinion, that this Beetle is the Bpro mention'd Foel i. 4-and ii. 25. So alfo the ingenious Dr. Molyneux of Ireland is of the fame Mind, and thinks that our Engliff Verfion errs in frequently tranflating it the Canker-Worm, which is a Reptile; whereas in Mal.iii. 16,17. the $\mathrm{B} p \tilde{z} \chi \theta$, faith be, is faid to $f y$, and to have Wings; and its Nature and Properties are moft truly and particularly defcribed in the fe Words, It fpoileth and flyeth away, they camp in Hedges in the Day, and when the Sun arifeth they flee away, and their Pace is not known where they are. I need not take Notice that the 70 mention in this Place, the 'Axeis and

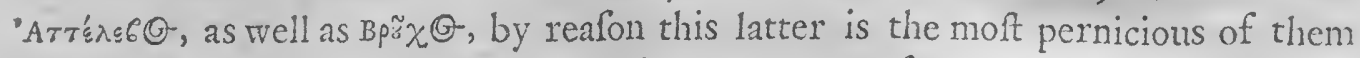
all. But it may be worth obferving, that the Bp $\tilde{\alpha} \Theta$ of the 70 , is a Tranflation of fuch Hebrew Words, as greatly denote our Beetle. Thus in Levit. xi. 22. I King.

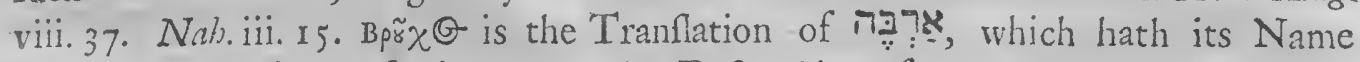
from a Multitude, as fetting upon the Deftruction of any thing in Troops and great Numbers. In 2 Chron. vi. 28. the Original Word is 4 पT Abfumptor, Depaftor. And lafty in Amos vii. r. the Word in the Original fignifies grcen Corn or Herbs. All which are very applicable to our Chafer, which flies in great Numbers, and preys on, and confumes the green Plants in great abundance; of which we have divers difmal Accounts; particularly one from the laft named Dr. Molyneux, who faith, that $A$ fbort while after their coming (into Lieland) they had fo entirely eaten sp and deftroy'd all the Leaves of the Trees for fome Miles round about, that the whole Country (alibough it was in the middle of Summer) was left as bare and naked, as if it had beein in the Depth of Winter. And the Grinding of the Leaves in the Mouths of this vaft Multitude all together, made a Sound very much refembling the Sawing of Timber; with a great deal more Mifchief, for which I referr to the Philf. Iranfa.t. $\mathrm{N}^{\circ} 234$. or Mr. Lowthorp's Abridg. Vol.II. p. 779.

Moufet alfo tells of another Mifchief they did, in his Theat. p. 160. viz. Anno Chrifti 1574. Feb.24. tantam eorum multitudinem in Sabrinam fluvium delatfam, ut aquaticis Mulendinis rotas ffferent atque obrueient: Et fane nifi una cum bominum induftria, galline, anates, caprimulgx, tinnunculi, verfpertiliones, alikque pradatrices aves (qua hos in primariis babere cibis videntur) auxilio fuiderat, Juffocata ab iis Molendina etiamnum bodie obmutuiffent. As for the great Numbers of thefe Infecis here mention'd, no doubt can be made; but the latter End of Febiuary was a very improper Time for their Appearance.

'Thefe Beetles, Moufet faith,were a delicious Food to divers Birds; and fo Lr. Mobineux faith they were to the Swine and Pontwey, which watch'd under the Trees for 


\section{[ i 7 ]}

their falling, and eat them up in abundance, being much pleafed with the Food, and thriving well upon the Diet. Nay (faith he) I have been well afJured, that the poorer Sort of the Native Irih, (the Country then labouring under a Scarcity of Provificns: bad a Way of Dreffing them, and lived upon them as Food.

Thefe Beetles I have myfelf alfo obferved to be coveted by divers Birds; particularly I have feen Sparrow-Hawks catching them at the Tops of Trees, when they have been flying about there in the Summer Evenings. Thefe Hawvs firft catch thefe Beetles in their Bills, then very dextrouny take them thence with their Talons, and fo feed on them, flying about all the while, and picking what they like in them.

Having feen many Creatures eating thefe Beetles, I have had the Curiofity to tafte them myfelf, and found their Tafte not difagreeable, but grateful: Which minds me of Dr. Molyneux's ingenious Obfervation, about the Permiffion of the Ferws to eat thefe Kinds of Animals, Lev.xi. 22. I muft confess (faith he) it long feemed.to me very unaccountable, that here among the pure, wholfome Creatures, proper for Human Nourifoment, Beetles, and thofe other nafty, dry, and unpromifnng Vermin, Bould be thought fit to be reckon'd up as clean and proper for the Food of Man: But fince I have had fome little Experience of what hath happen'd among ourfelves, I cannot but admire the Sagacious Prudence of that Divine Lawgiver. 'Tis certain, Paleftine,' Arabia, Egypt, and the other neighbouring Countries about them, were all extremely fubject to be infefted with the fe Sorts of pernicious Vermin; and therefore, Mofes forefeeing the great Dearth and Scarcity that they might one Day bring upon bis People, gives them isere a permiffive Precept, or a Sort of Hint, what they foou'd do, when the Corn, Grafs, olive-Trees, Fruit-Trees, Vines, and other Provifions were deftroy'd by the Locuft, and $\mathrm{B}_{\mathrm{p} \mathbf{x}} \mathrm{x}$ ss, or Beetles fwarming in the Land; why then, for want of other Nourifbment, and rather than ftarve, be tells them they might eat, and live upon the filthy Deftroyers them Selves, and yet be clean. And thus we See the Native Irith were Authors of a Practical Commentary on this Part of the Levitical Law, and by Matter of Fact, have explain'd what was the true Senfe and Meaning of this, otherwife, fo dark and abftrufe a Text. It is alfo more than probable, that this fame deftruttive Beetle we are fpeaking of, was, that very Kind of Scarabxus, the idolatrous Egyptians of Old had in fuch high Veneration, as to pay Divine Worßip unto it, and fo frequently engrave its Image upon their Agulios and Obelisks; as we fee at this Day. For nothing can be Juppofed more natural, than to imagine a Nation, addiczed to Polytheifm, as the Egyptians wore, in a Country frequertly fuffering great Mifchief and Scarcity from Stvarms of devouring Infects, Shou'd, from a frong Senfe and Fear of Evil to come, (the common Principle of Superftition and Idolatry) give Sacred Worfip to the vifible Authors of the fe their Sufferings, in hopes to render them more propitious for the future. T'hus 'tis allow'd of all hands, that the Same People adored as Gods the ravenous Crocodiles of the River Nile; and thus the Romans, tho' more polite and civilized in their Idolatry, Febrem ad minus nocendum venerabantur, eamque variis Templis extructis colebant, Says Valer. Max. Lib. II. Cap. 5. 


\section{[ 18 ]}

\section{PLATE LXI.}

L 1N. 2. After Orach, Note I. Goedartius faith, Hoc Erucarum genüs herbafcenti Tritico inferpens offendi; aft alibi fruftri quafivi. Alfo that, Perniciof a funt animalcula; filiquas enim, feu Folliculos virides, quibus Triticum increfcit, exedunt. Now, how to reconcile Mr. Albin's Account of its Eating fmall Infeets on the Orach, with Goedartius faying he never found it on any thing but green Wheat; is not eafy, unlefs the Animalcule, when it firft comes out of the Egg, fhould feed on the Leaves of the green Wheat, and afterwards (a little before its Change) Thould feed on fmall Infects. For it was but a Day or two before their Change, that Mr. Albin found them eating Infeets; and I myfelf have often obferved them on Pales, fome clofely adhering thereto, and fome hunting fmall Infects thereon.

In the Year 1707, I had an Opportunity of obferving the Generation of the Lady-Cow; which was thus: This Beetle having laid an Egg, (if I mifremember not, it was but one) and cover'd it with a filken Membrane, then betook itfelf to Incubation, covering the Egg, (as an Hen doth) by laying its Belly clofe over it ; from whence I could not without Difficulty, and hurting the Lady-Corw, remove it. I had not the Fortune to fee the Nymphe hatching, but foon after, in the beginning of May, I faw divers of them creeping about.

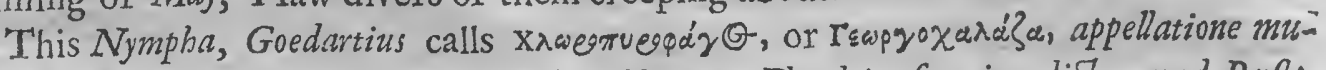
tuatâ à quodam Propugnaculo in Dicecefi Hulftana in Flandria fito, ita dicto, quod Rufticis fuerit calamitas, eofque belli tempore vehementè infeftarit, Lifter's Goedart. $N^{\circ}$ II 2.

Lin. 7. After Beetle, Note 2. Goedartius faith, That from the Nympha of this Lady-Cow, came Animalculum maximi fitibundum. (Which I fuppofe he means the Beetle itfelf, not the Aurelia, becaufe I conceive the Aurelia cannot remove from its Place) Namque fimulac prodierat, largitèr o Sape bibere obfervavi. Ex quo conjecturam feci, natura boc Animalculum effe calidioris. From which its fiery Temper, and its feeding upon green Corn; I fuppofe, he gave it the former of the two Names, of the Green Fire-Eater, as he did the latter from its hurting the Husbandman's Corn. See Liffer's Goedart. before cited.

Mr. Petiver gives the Name of Cocbinella Anglica vulgatiffma, Seu rubra, 7 ( rather 6) nigris maculis notata. He calls it Cocbinella, I fuppofe, becaufe (as he told me himfelf) it ftrikes a Dye, not much inferiour to that of the true CochineleFily.

Lin. I2. After $d$, Note 3. Of this Nympha or Grub, Goedartius faith, Rarò invenitur, fiquidem ferè femper latitat in fundis lapidofis o bumidis, quandoque tamen in Hortis grafjatur; conqueruntur enim Hortulani aliquando non levem herbis bunc inferre nuxam; nec admodum facilis captu eft; novit enim callidus Sub terra Se occultare, nut aliquem perfentifcens motum aut agitationem, confeftim in illam irrepere. Omnis generis herbis vefcitur, earumque radices exedit; vorax admodum eft, atque vix Saturandus. And afterwards, Difficultèr extirpari poteft, ita callidus of aftutus eft, ut nunquam ferè totus extra terram smineat, Jed capite folummodo, quod confeffim novit intrò trahere, ad 


\section{[19]}

minimum quod Sentit, auditve frepitum, extemplo fe proripit, or fe abdit in latibulum; neque capiendo eft, nec exturbando, nifz beneficio ligonis. Probè etiam ipjs perfpectum ede videtur, ipfum invifum effe ơ exofum hominibus; quocirca eos, veluti Moiten horret.

Swammerdam fays, $P_{i}$ catores Belgas vernaculo idiomate Im vel Imme vermiculum boc vocare.

Lin. 17. After Fly, Note 4. This Fly, Swammerdam calls by the Name of Tipula terreftris; and both the Male and Female are thofe defcribed by Aldrowand, in his $3 \mathrm{~d}$ Book de Infectis, Cap. 5. Tab.I. $N^{\circ}$ 3. and Tab. III. No I. which he took to be two diffinet Species of the Culices maximi. Goedartius faith, that both Boys, and others call them Nayer, that is, Taylors, (according to our Englifls Name) but for what Reafon he can't tell. Dr. Lifter faith, they are call'd Drummers, in his Note on Goedart's 139 th, and that they lay Eggs of a Violet Colour, and that he obferved five Species of them in England.

Thefe Taylor-Flies, faith Goedartius, admodum Junt calidi $\delta$ falaces. Decuplo quidem plures numero Mafculos invenire eft bujus generis, quam Famellas, quod mirandum eft. Hoc etiam experiemini, fi animadvertitis, uti ego bifce oculis fape vidi, ubi Mafculus cum Famella coit, plerumque 5 vel $6 \mathrm{Ma}$ culos circumvolitare ultrò citroque, quorum finguli fuas Coeundi vices praftolantur, of priores captare moliuntur of fatagunt. Cui autem prima dantur vices fe cum Fomella mifcendi, is ei per biduum continuum affixus manet; Or Solutus Masculus, non admodum diu poft moritur; Sed Juperftes Famella manet. Ubi vero Famella semen, ó quod concepit, jam excernendo maturum factum eft, poftremum illa corpus terre infigit, atque femen in ea deponit; ex quo noxium hoc Animal, Brucbus bic, ducit originem; qui non, nifi quum tres jam babet annos progignenda Sarto-. mim foboli aptus eft.

This wife Provifion of the Divine Providence to reftrain the too great Propaga= tion of this fo noxious a Creature, Goedartius pioufly adwires and celebrates, and exhorts, Grati, quaso agnofcite, o depradicate.

In this Infect, Aldrowand takes Notice, that Sub Alis duas habet Appendices curro apicibus, qua Insestorum quorundam Antennas mirum in modum referunt; fed in quem finem his à Natura dotetur, me, ut verum fatear, adbuc latet, cum eas in aliis Infectis me obfervale meminerim munquam.

Thefe Appendices are very remarkable in this Fly, rather more than others, by Atanding out pretty far from the Body, and having pretty large Apices or Balls at the Ends: Whereas in other Flies; thofe Pointils or Poifes lie under a little Covering, like a Shell, at the Bottom of the Wings, or their Conjunction to the Body. Thefe Poifes are only found in fuch Infects as have only two Wings, and never in fuch as have four. And their Ufe is to Poife the Body, and keep it upright and fteddy in Flight; like the long Pole ufed by Rope-Dancers for the fame Pur pofe. But of this fee my Phyfico-Theol. Book VIII. Chap. 4. Note" . 


\section{$[20]$}

\section{PIATE LXII.}

LIN. ult. After Fly, Note I. This Fly is not of the Ichneumon-kind; but what may be ftrictly called, of the Fly-kind, as appears by this very Figure of Mr. Albin; as alfo by the Fly itfelf, which I have hatched. For the CharacteriftickNotes of the Icbreumon-Tribe, are four Wings, and the Alvus flender at the Upper Part near its Juncture to the Thorax. But our Turnep-Fly hath but two. Wings. and a cylindrical Alvus, as many other Flies generally have.

\section{PIATE LXIII.}

1N. 8. After $e$, Note 1. This Maggot is that which Dr. Plot defcribes in his Hift. of Staffordbire, under the Name of Eruca glabra caudata aquatico-arbo. rea; becaufe he found it in the Water ftagnating in an hollow Tree; but it is common in Sinks and Puddles of dirty Water, $\sigma_{c}$. This, ob Origenis foeditatem, Vermiculum Porcinum appellavi, faith Goedartius, $\mathrm{N}^{\circ} 126$. Thefe Maggots he rightly fays, Latebras quarunt in fifuris or rimis veterum parietum. In which Places I have myfelf found them either in their Chryfalis-ftate, or preparing themfelves for it : But for a further Account of this Maggot, and the Bee-like Fly that it produceth, fee my Phyfico-Theol. Book IV. Chap. 15. Note ro.

Lin, penult. After Bee, Note 2. This Infect is very like a Bee, but is of the Fly-kind, having but two Wings, whereas Bees have four. Of whofe Wings Goedartius hath a pretty Obfervation, $N^{\circ}$ 126. wiz. Quum primum natam hanc Apem confpicerem, Alis ean careve exiftimabam; nam earum loco nibil potui animadvertere, praterquam duas exiguas maculas albas, inftar fummitatum vulgarium acicularum; Sed ftatim cœpit Apis macudas illas albas pofterioribus Suis pedibus explicare; ac Jpatio duarum horarum ita adaptavit, ut perfestam baberent Alarum formam, $\mathcal{G}$ ad Volatum effent idone... Mr. Ray defcribes this Fly, and its Nympha in Hiff. Infect. p. 272. The Fly he calls Mufca Apiformis, tota fufca, cauda obtufa, ex Eula caudata in Latrinis degente, orta.

\section{PL A TE LXIV.}

I IN. I. After Worm, Note I. Goedartius gives a curious Account of this Hexapode Nympha, (N॰104.) viz. Infolitum boc Animalculum admodum lentigradum eft. Ubi id vexas, \& ad iram extimulas, fe valde iracundum, \& fuccenfum prabet; infuper audax o imperterritums (quapropter illud Toлunề, Audax aut Intrepidum vocitare vifum eft) namque ftationem Suam Servare audax, non nifi ipfum magnopere infeftes, de loco proferpit. In pofteriori corporis fui parte, limofam geftat pinmam, qua $\int_{e}$ defendit, ac protegit, \& eam ubicunque deponit, iftius beneficio fe terra ita agglutinat, $\sigma$ ffigit, a ut non cedat retro'; tum corpufculum omne contrabit, \& anteriori ipfrus parte, $\&$ connttis, Seu dentatis, quibus eft armatum, forcipibus fe adverfus illatam fibi vim gnaviter. siletur.

Iin. 4. After Flies, Note 2. Having a great Defire to nurfe up this fo rare an Animal, Goedart offered it divers forts of Food; which it refufed, until 


\section{[21]}

hitting upon dead Infeets, particularly a Beetle, he faith, Se mirum in inodim oblectare, Scdrabaum omnem intivs exedere, in exefum irrepere cadaver, of parti ejus pofteriori nendo attexere fibi domunculum, exigue ad inftar Camera, ad latus utrumque. adeo amplum, ut in ea se commodè podet quaquaverfum flectere.

Lin. 8. After Fly, Note 3. This is that Fly which Moufet gives the Nama of Chrysopis to, from its beautiful Gold-colour'd Eyes, Theat, Infect. p.62.

\section{PLATE LXVI.}

TIN. I After Nogyot, Note 1. This Nympha is the very Maggot defcribed by Goedart, agreeing in its Way of Feeding, and all other things here mention'd with Guedart's; but the Fly which he obferved to be produced, was fpurious, being only one of the larger Icbneumon Flies, Lifter's Goed. $N^{\circ}$. r 34 .

Lin. 12. After Fly, Note 2. This is the Block-beaded Bee-Fly.

\section{P. I, TE LXVII:}

L IN. 12. After Caterpillers, Note I. I know not of any Caterpillers of the Ichneumon-kind; but the Ichneumons bred in Caterpillers are fuch as are generated from the Eggs of Ichneumons laid in thofe Caterpillers. Which Eggs produce Maggots, not Caterpillers. So that the Caterpiller is fo far from being a Paient, or Nym= pha of the Ichneumon, that it ferves only as a Matrix to its Generation: But the Infeet that comes from thefe Caterpillers, I take to be a fmall white Moth, much feathered.

\section{PIATE LXX.}

LIN. r. After Caterpillers, Note r. Merian, in her Defcription of the Greater Tortoife-fbell Butterfly, Part I. $N^{\circ}$ 2. faith, Priufquam metamorplofon Jubeant, repetitis vicibus deponunt exuvias; poftmodum albam fibi telam parantes in Aurelias fufcas transfgurantur. Now, if the means the Caterpillers of the Tortoife-fbell Butterfy, (the was defcribing, that weave themfelves fuch Webs) it is a great Miftake; but it is evident from her fecond Figure, that it is the Caterpillers here deforibed which make thofe white Webs. For only Caterpillers, never Butterfies weave any Wels

\section{P.LATE LXXII.}

I IN. r. After Caterpiller, Note I. If this be Goedart's 4 rft Caterpiller, it hath this odd Faculcy, viz. Sub terra de die perpetuo latitat, nec ante velperam foràs prodit; Sed nocturno tempore fibi alimentum comparat quod toto die ipfis fufficiat; adeoque Vesprrtilionibus quodammodo o Noctuis fomilis eft.

\section{PIATE LXXIII:}

I IN. I. After Caterpiller, Note I. It is probable that this Caterpiller is the $55_{\text {th }}$ of Liffer's Goedartius. And if fo, it Cibum fumit nocturno tempore (faith Goedartius) de die immota quiefcit, metuens ne ab avibus deprebenfa devoretur. And for 


\section{[22]}

for this its fafe Repofe by Day, it prepares itfelf a Cafe, by folding up (round) the Leaves of fuch Plants on which it feeds.

\section{PI ATE LXXVII.}

T.1N. 5. After Moth, Note I. If Mr. Albin hath truly painted this Moth, $\mathcal{L}$ and that mark'd $g h$, in 'Tab. LXXIX. following, then I think this to be that Moth défcribed by Mr. Ray, rather than that. Mr. Ray calls his Moth, Phalona è mediis minufcula, alis exterioribus cinereo $\underset{\sigma}{ }$ nigricante colore variis, mediâ parte line $\hat{\imath}$ albâ y literam aliquatenus referente, notatis, Hiftor. Infect. $\ell .163$. And the Defcription which he gives afterwards of the Colours of the Upper and UnderWings, agrees nuch better with this Moth, (which is throughout of a dark Colour) than with the other, which hath its Upper-Wings of a reddifn Colour.

\section{Plate LXXIX.}

IN. 7. After e, Note x. The Caterpiller e agrees with Goedart's 14th in $\mathcal{L}$ the two Holders, near the middle of the Body, (which are rare) but the Moth is not the fame. Some other of Goedart's Caterpiliers alfo agree in thefe laft mention'd Holders, as his two next, viz. $\mathrm{N}^{\circ} 15,16, \mathcal{*} c$. but the Moths are likewife different.

Lin. is. After $\Upsilon$, Note 2. This Muth I take to be that which Mr. Petiver hath named the Lambda-Moth, from the white Mark in each Wing, refembling the Greek $\Lambda$. which Moth he hath figured in his Gazophy?. 'Tab. LXIV. No 6. Mr. Ray defcribes alfo a Moth called the $r$; of which fee Tab. LXXVII. before.

\section{PLATE LXXXIII.}

IN. I. After a, Note I. This Caterpiller is Aldrovand's I6th, in his 3 d Table; which he faith, Facta, Se velut in vertibulum contorquens, Stella frguram exprimit coronata.

Lin. 7. After Web, Note 2. The Briftles or Hair of Caterpillers is of great Ufe to them, in thefe two, among other Refpects. I. To be a Guard unto, them againft the Annoyances from Birds, Infeets, and even Caterpillers themfelves; fome of which Goedartius hath obferved, will, for want of Food, devour one another; of which fee the Notes on the 25 th Plate before. 2. To affift in making their Web, for their fafe and comfortable Repofe in their Aurelia-fate; thefe Briftles not only affording Materials for the Web, but alfo Strength and Firmnefs to it. And it is very obfervable, what an excellent Provifion is made of a glutinous Matter in the Body of the Caterpiller, for the cementing thofe Briftles together; and with what Sagacity and Art the Caterpiller both weave and cement them into a Theca, or Cafe. 


\section{[23]}

\section{PLate LXXXIV.}

TIN. 3. After Willow, Note r. Goedartius faith, Calore folis provenit ex fe1 mine quod foliis Populi adharebat. And as for its Food, Delectatur foliis $P_{0-}$ puli $\&$ Salicis, que fimilis ferè funt nature $\&$ temperamenti. And I know of no better (if fo good a Way) of judging of the Nature and Vertues of Plants, as by the Feeding of Caterpillers, and other Animals upon them; who are all endow'd with fuch complete Organs for the taking in, and Digettion of Food, and fuch accurate Senfes for the diftinguifhing what is wholfome or unwholfome, (of which I have given an Account in my Phys. Theol. Book IV. Chap. I I.) that it is reafonable to conclude fuch Plants to agree or difagree in their Vertues, as are chofen. or refufed by thofe fagacious Feeders: Of this fee Dr. Lifter before.

\section{PLA TE LXXXIX.}

L 1N. r. After Caterpiller, Note I. Both Goedartius and Mr. Ray defcribe this Caterpiller to have on each fide a Tuft of Hair, refembling Oars, which Mr. Albin takes no Notice of. Spatio inter pedes priores, (faith Mr. Ray, Hift. Infect. p. I74.) \& pofteriores medio, duo (binc inde unus) exeunt Pilorum fafciculi velut Remi; anterior pallidorum, pofterior nigrorum. Another Thing taken Notice of by Goedartius is, Magna anxietate pellem mutat, quotiefcunque id fit, corpus Suum madidum, ac fudore quafi perfufum, pluma ante defcripta (that is, with the hairy Antenna, and other Brumes and Tufts of Hair it is accouter'd with) abftergit $f$ deficcat. Tuta die poftea quiefcit fine alimento, os quippe ipfs totumque corpus folito mollius eft ac tenerius.

Lin. 8. After Moth, Note 2. Thefe Female Moths without Wings are not uncommon among fome of the Moth Tribe. Goedartizus hath taken Notice of two that produced fuch unwing'd Females; and Mr. Albin hath in this, and the two following Plates, taken Notice of three more, and another in Plate Ioo. Both thefe Female Productions Goedartius admires at, calling thăt 78 b. mirandum Animalculum, and this here figured (which is probably Goedort's 79th.) Animalculum miferum, quod neque Papilio effet, neque Eruca. 'The Reafon of its Degenteracy (as he thought it) he faith, was, Quod ante tempus à cibo abfinuiflet, $\mathcal{O}$ corpore nondum Satis per-' fecto ad Tranfmutationem perveniffet. 'The fame Opinion Dr. Lifter was of, who faith, Papilio fuit, Sed, ut Autbor probè obfervavit, Famelicum: Cujufmodi plures ipfe babui, quorum Alce adbuc imperfecta fuerant, aut faltem inhabiles ad expandendum. But I am clearly of Opinion, that both Goedartius and Dr. Lifter were miftaken; and that thefe which Dr. Lifter faith had fuch Ale imperfecta, or inbabiles ad expanden-. dum, were only fuch whofe Moifture was wafted, that I have fpolsen of before in. plate IV.

What I have more to fay about thefe Female Moths, I refer to my Note on the next Plate.

$$
\text { Plate XC. }
$$

LIN. 9. After Female, Note 1. One of thefe Female Moths, Goedartius gives a remarkable Deferion of, $N^{\circ} 786$. That it is Forma mirandum Animalculun Alis deftitutum, at Corporis Partem pofteriorem crafam, atque Ovis habens refertam, o 


\section{$[24]$}

nellucida Membranula obtectam, per quam Ova Se e confpicienda dabant. Poftero Die omnia deponebat Ova, \& fiquidem Membranula, ad inftar Verbafci, Lana cooperta erat. Lanam evellebat, eaque tegebat Ova fuas proculdubio ex ingenita fibi fagacitate, ut calida \& illasa manerent. Tunc temporis Nibil ei erat reliquum nifi Corporis Pars anterior, \& Pedes; \& Forma fua finilis Aranee, anteriori Corpore \& Pedibus progrediebatur.

By reafon of the great Care and Diligence ufed by thefe Fenale Moths in covering up their Eggs, Goedartius gives them the Name of Mseípval, or Careful.

This Production of the Female Moth, Dr. Lifter in his Note on Goedart's 786. thinks to be, Non Spurius, Sed Monftrofus Partus, qualis effet avis Exchufio abfque alis. In the next place he thinks it Magis adbuc mirabile, Prudigiofan banc Fomellam ova fua deponere. Which plainly thews, that the fagacious Doctor little dreant of its being a Female.

Mr. Ray hath a Female Moth like thefe in this and the preceding Table, which he calls Phalana cinericea ventricofa, curpore brevi, alarum expers; which he faith comes from fuch a like Pencilled Caterpiller as is here figured; only thefe here have not Tufts on the fides, as thofe have defcribed both by Mr. Ray and Goedartius. Vid. Ray's Hift. Infect. p. I73.

\section{PLATE XCI.}

I IN. I. After Caterpiller, Note I. This and the Moth following are both of the Geometer-Tribe, as are divers others in the following Tables.

\section{PLATE XCIV.}

1N. r. After Caterpiller, Note I. If this be Goedart's roth Caterpiller, there are feveral Things remarkable in it. I. That it feeds but once a Day, Semel 'duntaxat de die, vefperi nempe, poft Solis occafum, ubi tenebra ingruebant, circa mediam Sextam. Et quotiefcunque conabat, ad fatietatem jam pafta fe rectà extendebat, ơ in altum. Hoc in fitu eam nulli rei magis appofitè comparare poteram, quam Bacillo ex fafcibus faginis defumpto; à primo etiam intuitu pedes obfervare nequibam, nec tamen iis deftitutus erat. Befides its Feet, he obferves. 2. That in anteriori corpore illi erat prominens aut eminons Tuberculus, cujus beneficio ifti quodcunque attingebat, ita Se annectebat, Sugens continu, inftar Hirudinis, ut vix divellendo effet, imo Se potius in frufta diftrabi paflafuiflet, quam divelli. Befides which Tuberculus, he faith thus, Ita tenax etiam ipfspoftremum corpus erat; namque Aurifabri forcipem referebat, qua folet Crucibula foco eximere, of poftremam corporis pariem ad modum claufa Forcipis claudebat. Which Structure and Ufe of the hinder Feet or Holders is common to all the Caterpillers of the Geometer-Tribe. 3. He faith, Hoc in fitu, \& pofitura (i.e. erect, or as here painted in the lower Figure of this Table) quandoque totum diem defrdebat, tanquam inanimis, of immota, quanquam quaflata, ơ infeftata. But fometimes it would change its Pofture, Atque pendula capite deorfum vergebat, (as is here figured in the upper Part of this Table) ab hora 6 matutina ad 8 vefpertinam, qua folebat femper proferpere, noctuque edebat, \& interdiu dormiebat. 4. Upon the Failure of its Food, (which was Elder Leaves) he faith, Integram jejurabat hyemem, nibil agens aliud, 


\section{[25]}

praterquam guod fingulis fe noitibus movebat loco, wha notze pendens capite deorfum, of altera furfum, of Semper recta, extenfo sorpore. Ita fe obleztabat, of temporis fallebat tadium. Laftly, He takes Notice of this Caterpiller fwallowing frall Stone, or Gravel, to fcour its Maw.

Lin. 9. After Moth, Note 2. Mr. Ray calls this Moth, Phalana media ocbrolews. cos, alis ampliffrmis, exterioribus duabus lineis tranfverfis è fulvo virentibus, interioribus una divifis. Hitt. Infect. p. I77.

I take this Moth to be Mr. Petiver's I'apilio Araminea ftriata, in his Gazophyl。 Tab. LVII. 6.

20

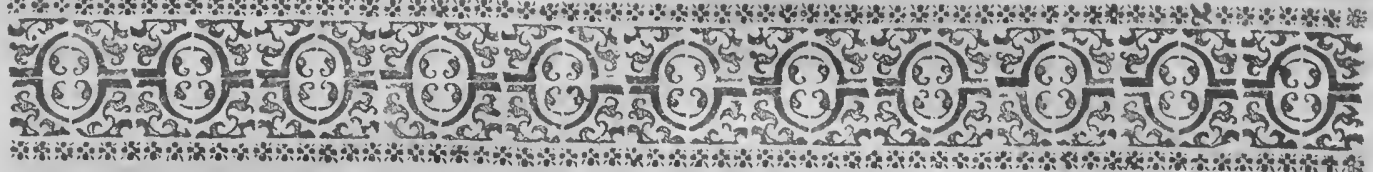

\section{Books printed for $\mathrm{W}$. and J. Innys.}

1. A R. Derbam's Phyfico-Theology ; or, A Demonftration of the Being and Attributes of God from his Works of Creation; being the Subftance of fixteen Sermons preach'd in S. Mary-le-Bow Church, London, at the Honourable Mr. Boyle's Lecturers, in the Years 17 I 1 and 17 I2, with large Notes, and many curious Obfervations; the 6th Edition, 8vo. 1723.

2. his Aftro-Theology; or, A Demonftration of the Being and Attributes of God, from a Survey of the Heavens, illuftrated with Copper-Plates; the 4th Edition, 8v0. I 721 .

3. Philofophical Letters between the late Learned Mr. Ray, and feveral of his ingenious Correfpondents, Natives, and Foreigners. 'To which are added, Thofe of Francis Willougbby Efq;. The Whole confifting of many curious Difcoveries and Improvements in the Hiftory of Quadrupeds, Birds, Fifhes, Infects, Plants, Foffils, Fountains, \&c. Publifh'd by Mr. Derbam, 8vo. 17 18.

4. Mr. Ray's Wifdom of God manifefted in the Works of the Creation, in two Parts, viz. The Heavenly Bodies, Elements, Meteors, Fu/fils, Vegetables, Animals, Beafts, Birds, Fifhes, and Infects; more particularly in the Body of the Earth, its Figure, Motion, and Confiftency; and in the admirable Structure of the Bodies of Man, and other Animals; as alfo in their Generation, $6 c$. with Anfwers to fome Objections; the 8th Edition, 8v0. 1722.

5. - his three Phyfico-Theological Difcourfes, concerning, r. The Primitive Chaos, and Creation of the World. 2. The General Deluge, its Caules and Effects. 3. The Diffolution of the World and Future Conflagration; wherein are largely difcuffed, the Production and Ufe of Mountains; the Original of Fountains, of Formed Stones, and Sea-Fithes Bones and Shells found in the Earth; the Effects of particular Floods, and Inundations of the Sea ; the Eruptions of Vulcano"s, the Nature and Caufes of Farthquakes; alfo an Hiftorical Accuunt 


\section{[ 25 ]}

of thofe two late remarkable ones in Famaica and England; with Practical Infe: rences, illuftrated with Copper-Plates; the $4_{\text {th }}$ Edition, 8vo. I72I.

6. Philofophical Tranfactions, $N^{\circ} 376$, for the Months of March and April 1723, continu'd and publifh'd by Dr. Furin, Secretary to the Royal Society. Where may be had, A complete Sett from the Beginning, in 32 Volumes, and moft of the Numbers feparately.

7. the fame abridg'd to the Year 1720, by Mr. Lowthorp and Mr. Motte, in 5 Volumes, 4 to.

8. Bibliotheca Literaria; being a Collection of Infcriptions, Medals, Differtations, $\mho^{\circ} c$. to be continu'd, $N^{*} 6.4$ to. 1723 .

9. Opticks; or, A Treatife of the Reflections, Refractions, Inflcctions, and Colours of Light; the $3 \mathrm{~d}$ Edition; by Sir Ifaac Newton Knt. 8vo. I72 Y.

ro. The Pofthumous Works of Dr. Robert Hooke; in which, I. The prefent Deficiency of Natural Philofophy is difcourfed of, with the Methods of rendring it more certain and beneficial. II. Of the Nature, Motion, and Effects of Light, particularly that of the Sun and Comets. III. An Hypothetical Explication of Memory; how the Organs made Ufe of by the Mind in its Operation may be mechanically underftood. IV. An Hypothefis and Explication of the Caufe of Gravity, or Gravitation, Magnetifm, $\sigma c$. V. Difcourfes of Earthquakes, their Caufes and Effects, and Hiftories of feveral. To which are annex'd, Phyfical Explications of feveral of the Fables in Ovid's Metamorphofes very different from other Mythologick Interpreters. VI. Lectures for improving Navigation and Aftronomy, with the Defcriptions of feveral new and ufeful Inftruments and Contrivances; the Whole full of curious Difquiitions and Experiments, illuftrated with Sculptures. To thefe Difcourfes is prefix'd the Author's Life. By Richard Waller, R.S. Secr. Folio.

II. Pharmacopocia Extemporanea ; or, A Body of Medicines; containing a thoufand Select Prefcripts anfwering moft Intentions of Cure. 'To which are added, Ufeful Scholia, a Catalogue of Remedies, and a copious Index for the Affiftance of young Phyficians: The third Edition, with large Additions, by the Author Tho. Fuller, M. D. 8vo. I7I 9 .

12. The Hiftory of Cold Bathing, both-Ancient and Modern, in two Parts. "The firtt by Sir Fohn Floyer, of Litchfield, Kt. The fecond treating of the genuine Ufe of Hot and Cold Baths; together with the wonderful Effects of the Bath Water drank hot from the Pump, in decay'd Stomachs, and in moft Difeafes of. the Bowels, Livor, and Spleen, \& $c$. 'The fifth Edition, with Additions, By Edw. Baynard, M.D. 8vo. I 722.

13. Joannis.Raii, Synopfis Methodica Avium \& Pifcium; Opus Poftbumum, quod vivus recenfuit \& perfecit ip.e infrgniffmus Author; in quo multas Jpecies, in ipfius Ornitbologiâ o Iicbthyologia defiderata, adjecit: Metbodumque fuam Pifcium Natura magis convenientem reddidit, Cum Appendice, \& Iconibus. I 7 I 3 .

14. Anthropologia Nova; or, A New Syftem of Anatony, defcribing the Animal OEconomy, and a Thort Rationake of many Diftempers incident to Human Bodies.; illuftrated with above 80 Figures drawn after the Life. By Fames Drake, M.D. late Fellow of the College of Phyficians, and R.S. The fecond Edition corrected; with a Preface by W. Wagftaffe, M.D. and Reader of Anatomy at Surgeons-Hall, in two Volumes, 8vio. I7I 7 .

15. An Effay concerning the Knowledge and Cure of moft Difeafes affieting Heman Bodies. To which is annex'd, A fhort Account of Salivation, and the Ufe of Mercury. By P. Paxton, M. D. 8vo. 


\section{An I N D E X to Mr. A $\overline{\mathrm{L}} \overline{\mathrm{B}} \mathrm{I}$ ' 's Plates and Defcriptions, and Mr. DeRHA M's Notes upon tbem.}

A.

$\mathbf{T}$ 89,90 .

A She-colour'd Moth, Plat. 23.

Audax Eruca.

B.

REau Caterpillar, Plat. II.

Bees Charafteriftick. Nor. p. 20.

Blackberry Buds, bow eaten, Plat. 5 .

Blackifh Moth, Plit. r 4, 22, 27, 28, 29, 85.

Black and WhitifhMoth, Pl. I I $43,65,83,84,87$.

Black and Golden Moth, Plat. 73, 84.

Black Tail Moth, Plat. 87.

Bluifh Butterfly, Plat. 52 .

Bluith Moth, Plat. 48.

Blind Peetle, and the Proverb. Not.p. 16. Block headed Bee.Fly, Plat.66. Not.p.21. The admirable Provifion for its Young.

Bold Caterpillar.

Brimftone Butterfly, Plat. 2.

Not. p. 21 .

Prilles of Caterpillars ufed in Nidification, Plat. 22.

Not. p. 6.

- Are a Guard againft Harms. Nor. p. 5, 6 .

Brown Butterfly, Plat. 52 .

- Moth, Plat. 6,7,8,13,14,25,27,28, 29,31,

$37,45,49,67,70,74,75: 77,78,86,88,90$.

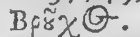
Not. p. 16.

Buff.colour'd Moth, Plat. 13, 24, 39, 41, 65, $60,81,85,96$.

Bunched-Back Caterpillar, Plat. 14, 40, 4I, $43,46,69,80,86,94,95,96,97$.

Butterflies Purgationbefore their Change. Not.p.2. C.

CAbbage-Butterfly, Plat. т:

U To preferve from them, P1.1, 28,39,43. - Their Seafons.

Careful Moth.

Caterpillars ftinging.

Not.p. I.

Not. p. 3 .

- With borned Tails, Plat. 6, 7.8, 57.

- Their Dexterity and Provifion for making Cafes to lie fecure in, Plat.1 1. Not p.4,5,10,22. Craft to dodge the Eje of Spetteitors, \&c.

-..Monfrous, Plat. 58.

Poysonous.

Not. p. I2, 18.

Cleanly.

Not.p. 15.

- Change to Aurelix.

Not.p. 15 .

Not.p. II.

Not. p. 13 .

Witbont Feet, that creeps like a Snail, Plat.68.

- That feed only by Nigh.

- That frallows Stones.

- Alone weave Wels. Not. p. 21.

Not. p. 2I, 24.

Not. p. 25 .

Canker-Worm, or the voracions Caterpillar of the Scriptures.

Chafer, Plat.60:

Not. p. I6.

Chryfopis, Plat. 64.
Chryfalides of Butterflies bow bung up, Plat. 2, $5 \mathrm{I}, 52,53,55$.

Not. p. I3: Why long in hatcbing in Boxes, Plat. 8. - Wonderfully bear Cold, ibid.

Cochinele.

Comma Butterfly, Plat. 54.

Not. p. 18.

Coffus.

Crab Caterpillar, ibid.

Cuckow's Food, Plat. 23.

DEER, how and why they change their Horns.

Devil's Gold-Ring, Plat. 8r.

Diffembling Caterpillar, Plat. 24. Not.p.5.

Domeftick Moth.

Drinker Caterpillar, Plat. I7.

Not.p. 8:

E.

F GGS of Infects not prolifick without the Male.

Not. $p .3$. Remarkable Provifion for their Security N.p.i

How laid by Infects. Not.p.I2.

Egger Caterpillar, Plat. 18.

Egyptians Worfhip of the Beetle. Not.p. 17.

Elephant Caterpillar, Plat.9. Not.p.4:

Erucaraneus. Not.p. 15.

Efcaloped winged Moth, Plat. $10,30,32,42,06$.

- Butterfy, Plat. 54.

Eyed Hawkmoth, Plat. 8:

Eyes cover'd by fome Moths, Plat. 88. Not.

Extenfor Eruca.

p. 7, 24.

F.

Not.p. 12 . $\mathrm{H}_{\text {Emale Moth of a rare Sort, Plat. } 36,89 \text {; }}$ 91, 100.
Not.p. 23,24.

Fire.Eater.

Caterpillar, Plat.8I.

Flies Charaeteriftick. Not. p. 20.

Not. p. 23,24 . Not.p.is.

From Caterpillars, Plat. 13, 17, 19, 24,

Flefh colnur'd Moth, Plat. 42, 49, 50, $76,03 \cdot$

Food afforded by Beetles.
Not.p. I 7 :

Caterpillars Patience of the Want of it.

Not. p. 5, 24.

- Admirable Provifion in Caterpillars to get

it, Plat. 39. Not. p. II, 24:

Fuillemort coloured Moth, Plat. 47.

$\mathrm{G}$.

CEmeter Caterpillars, Plat. 39,47, 91, 92; (I 93, 94, 95, 28, 99. Not.p. I1, 24. Goat Caterpillar.

Golden colour'd Moth, Plat. 7x, 84.

Grallatoria Eruca.

Green Butterfly, Plat. 5, 52.

Not. p. 9.

Moth, Plat. 22, 31, 48, 50, 72, 82.

Golden-ey'd Fly, Plat. 64.

$H$.

HAIR freaked Butterfly, Plat. 5, 52.

11 Coloured Moth, Plat. 26, 34,35.

- Of Caterpillars USe, Plat. 22, NVor. p.6. 


\section{An INDEX, ઉc.}

Hawks Delight in Beetles.

Moths, Plat. 7, 57.

Harry Long Legs, Plat. $6 \%$.

Hearing in Caterpillars quick.

Holes in Timber, how eaten. Not. p.9.
Horned taild Caterpillars, Plat.6,7,8,9,10,57.

Siroke venomors, Flat. 10. Not.p. 3, 4:

Horfe-Fly, Plat. 63 .

\section{I.}

Not.p. 20.

Chneumon Flies bred in Caterpillars of a

1 lefJer Sice, PIat. I, 3, 4. Not.p.r.

- Of a middle Size, Plat. 20, 23, 27, 28, $37,47,67,72,89:$

Of the larger Sort, Plat. 7, 9, 11 .

Spinning Silken Cajes, Plat: 8, 20, 34:

- Very Venereous.

- Charadterifticks.

Maggots only, not Caterpillars produced
Not them.

Jews Permifion to eat Locufts.

Im Caterpillar.

Intrepida Eruca:

L.

T Actucarix Erucx:

Ludy Cow, Plat. 61:

ItsGeneration, Incubation, and Food. Not.p. 18. Lambda Moth, Plat. 79.

Leopard, Tellow Royal.

Lobfter Caterpillar, Plat. 58.

Looper Caterpillar Plat. 39.

M.

I Agpy Moth, Plat. 37.

Maggot witha long Tail, Plat.63. Not.p 20.

MaleandFemaleInfeets, bow diftinguifh'd.N.p 17.

May-Beetle, Plat. 60.

Meadow Butterfly, Plat. 53.

Mseíuvat Moths.

Meticulora Eruca.

Not.p. 24.

Moifure ejected by Caterpillars, Plat. ${ }^{2} .8$.

Molitores Erucre.

Moth, great ftreak'd, Plat. 6.

Mullen Caterpillar, Plat. 13.

Munda Eruca.

NEttle Butterfly, Plat. 3,4 .
O.

Live colosred Moth, Plat. 38, 62. Orange coloured Butterfly, Plat. 54 .

Moth, Plat. I5, 21, 68, 75.

Dinted Lady, Plat. 56 . Parefca Eruca.

Peacocks Eye, Plat. 4.

Pencilled Caterpillars, Plat. 27. Not. p. 7.
Plants Vertues to difcover.

Poifes ander Infects Wings.

Purple Spotted Moth, Plat. 95: $R$.

R Abbets.Dung Fly, Plat. 7s: Ragwort Moth, Plat. 35 :

$p .7,13$.

Not. p. 15 . Not. p. II.

Not.p. I4. Not.p. I4. Not. p. Ig.
Not. p. 5 .

Evern laden with Chafers. Sexes of Infects, bowknon.

Silk-Worm, Plat. I2.

- Its Thred, bow long, ibid.

- Larger Cafes than ordinary.

Not. p. 14

Under Wing, Plat. 80, 100.

Reddin Moth, Plat. 16, 25, 27, 32, 43, 89, oo.

Ringing Caterpillar.

Not.p. 14.

s.

Not.p. 16. ,

Not.p. 7 .

Not.p.14.

Not. p. 5 a and $x$ by changed. Not. p. 3, 8, 23 .

Not. p. o:

Spiders changing their Skin, how done Not. p.8.

Star-like Caterpillar, Plat.83. Not.p. 23.

Straw coloured Moth, Plat. 36. T. dextroufly, Plat. o. $T$.

1 Taylor Fly, Plat. 61.

Not.p.12.

Great Providence to prevent their Increafe.ib.

Terrible Caterpillar, Plat. $14,5^{8}$.

Timorous Caterpillar. Not. p.8, 10, I5.

Titmaufe Caterpillar.

Toגjeneìv Eruca.

Not.p.II.

Not.p. 20.

Tortoifethell Butterfly, Plat. 4, 54, 55 .

Tufted Caterpillars, Plat.26,89,90. Not.p. 7.

Turnep Fly, Plat. 62.

Ermiculus Porcinus. Vermis Staphylinus.

Not.p. 20.

\section{V.}

Not. p. 20.

Not.p. 15 .

Not.p. 9: W. Plat. 74. .

WEbs of Caterpillars, Plat. $67,70,87$.

Weftern Moth.

White Butterfly, the greater, Plat. I.

Not. p. 8 .

- With black Veins, Ylat. 2.

- The lefer, Plat: 51.

Whitifh Moth, Plat. 21, 24, 26, 37, 40; 41, 70, 91, 92, 97.

ings of the Papilionaceous Tribe folded np; $_{3}$ Plat. 36

Not. p. 10, 20 .

How expanded, Plat. 35. Not.p.2, 10, 23.

ood Caterpillar, Plat. 35.

Woopard, Plat. 82.

Ys to plants. Not.p. 18. Y.

Yellowifh Moth, Plat.17, 18,30,33,39,40,

$44,45,46,57,65,68,93,94,95,97,28$ 99, 100 .

With Red, Plat. 73.

Not: p. 2: Yellow Uuder-Wing, Plat. 73? 
T H E

\section{Description of the Firft Plate.}

T

HE CATERPILLER, $a$, is of a pale green, fpotted with black. It has a yellow Line down the Back; the Belly is of a yellowifh Colour with fainter Spots. They are found too frequent ly on Cabbage and Caulifowers from Zune to September. They feed alfo on Nafturtium, Horfe-Radifh, Scurvy-Grafs, stock Gilly-Flowers, and I believe on all Plants that have the refs Tafte. I took them about the Middle of September, and fed them on the Indian Cre/s till the latter End of the fame Month: They then tied themfelves up by the Tail, and crofs the Middle, and changed into a Cbryfalis, marked $b$ in the Copper Plate, and fo continu'd till the Middle of April, and then came forth the Butter-fy called $P$ apilio albus vulgaris ma$j \prime r$, the great white Butter-fly, the Male marked $e f$, the Female $c d$. The Male and Female of all or molt Butter-fies may, befides other Characterifticks, be diftinguifhed by their Alve or Bellies: Here the Belly of the Male is lanker and mo.e.cylindrical than that of the Female, which is bigger in the Middle, and tapering towards each End like a Nine-pin. The Fcmale hath commonly two black Spots in each upper Wing, and the Male's Wings only tipped with black. Mr. Derbam hath obferved fome of the Males to have one Spot on the upper Side of the upper Wing, and two underneath it; in the $F e$. males two above, and a fort of Shade of them only underneath.

'Tis very common, when this CATERPIL L ER has faftened itfelf up, inftead of changing into a Chryfalis, to have many fmall Mazgots come out of its sides, each of which immediately fpin themfelves up in a Cafe of yellow Silk. Thefe produce a fmall Icbneumon Fby, which is expreffed in the Copper-Plate at $b$; and fometimes initead of a Butter-fy, after the Clrryfalis has been changed, I have had thirty a forty Icbneumons of another kind come out of it, exprefs'd at $f$ in Plate $\mathrm{N}^{0} 3$; thefe eat their way out of the Chryfalis in feveral Places.

In order to preferve your Cabbages, Ëc. from thefe C A T E R pIL. LE is $S$, 'ris worth while to deftroy their (bryfa'ides in the Winter. They are commonly found under the Copings of Garden-Walls, Pales, or any Place a little theltered; and likewife their Eggs, which are of a deep yellow ( olour, longifh, elegantly ftriated, and ftanding upright. You will commonly find many of them together, and for the moft part on the under Side of the Leaves. See Goedart, Sect. r. Num. 7. Merian. Vol. 1. Chap. 45. Moufet, p. 103. Ray Hift. Infect. p. 113. Liff. in Goed. p. 16. Fig. 7. 


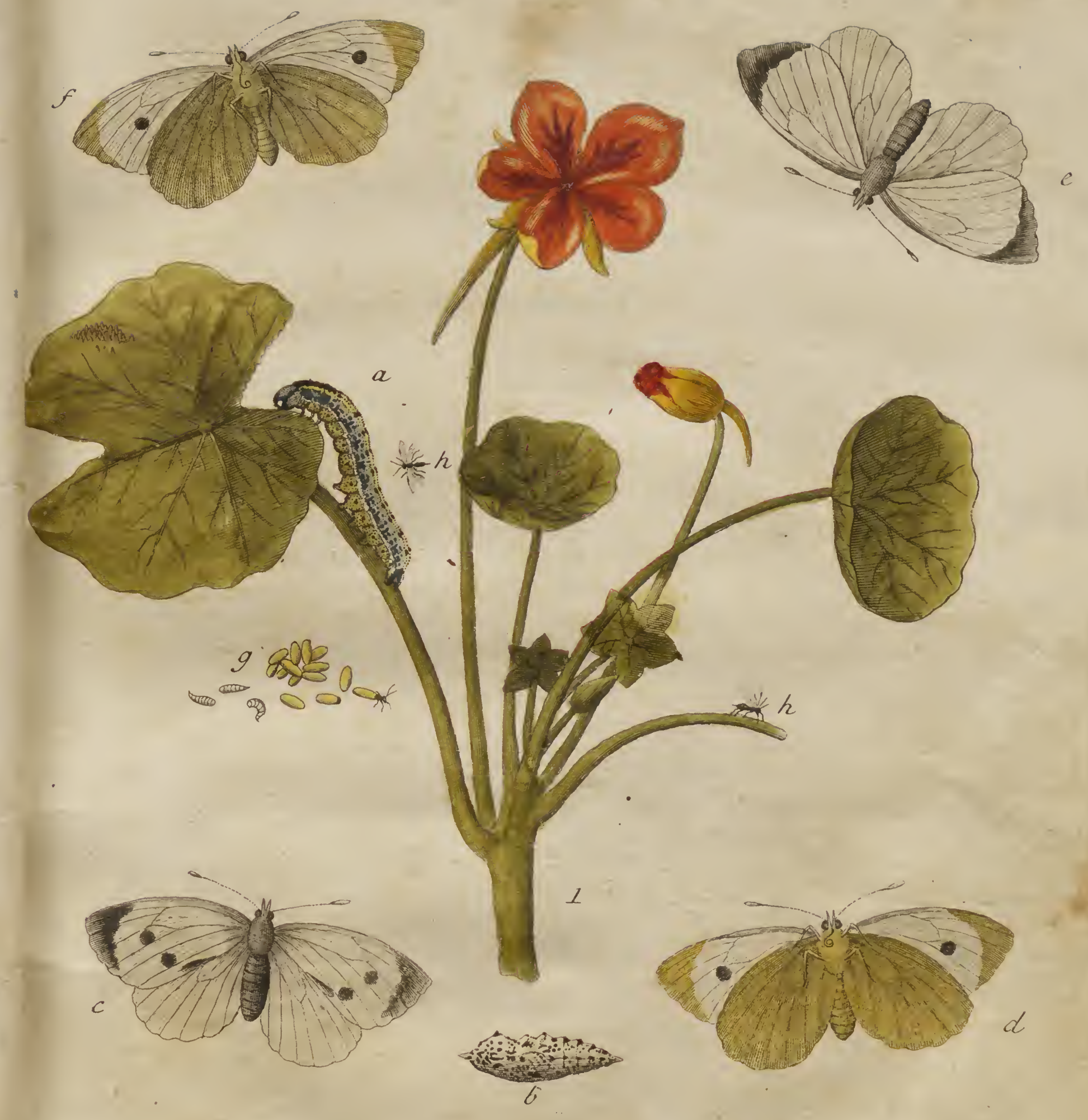

To Her Roy. Highness

- The Privirese of ll neses.

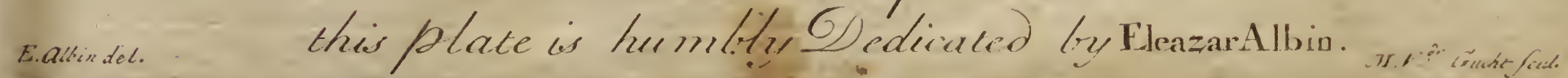



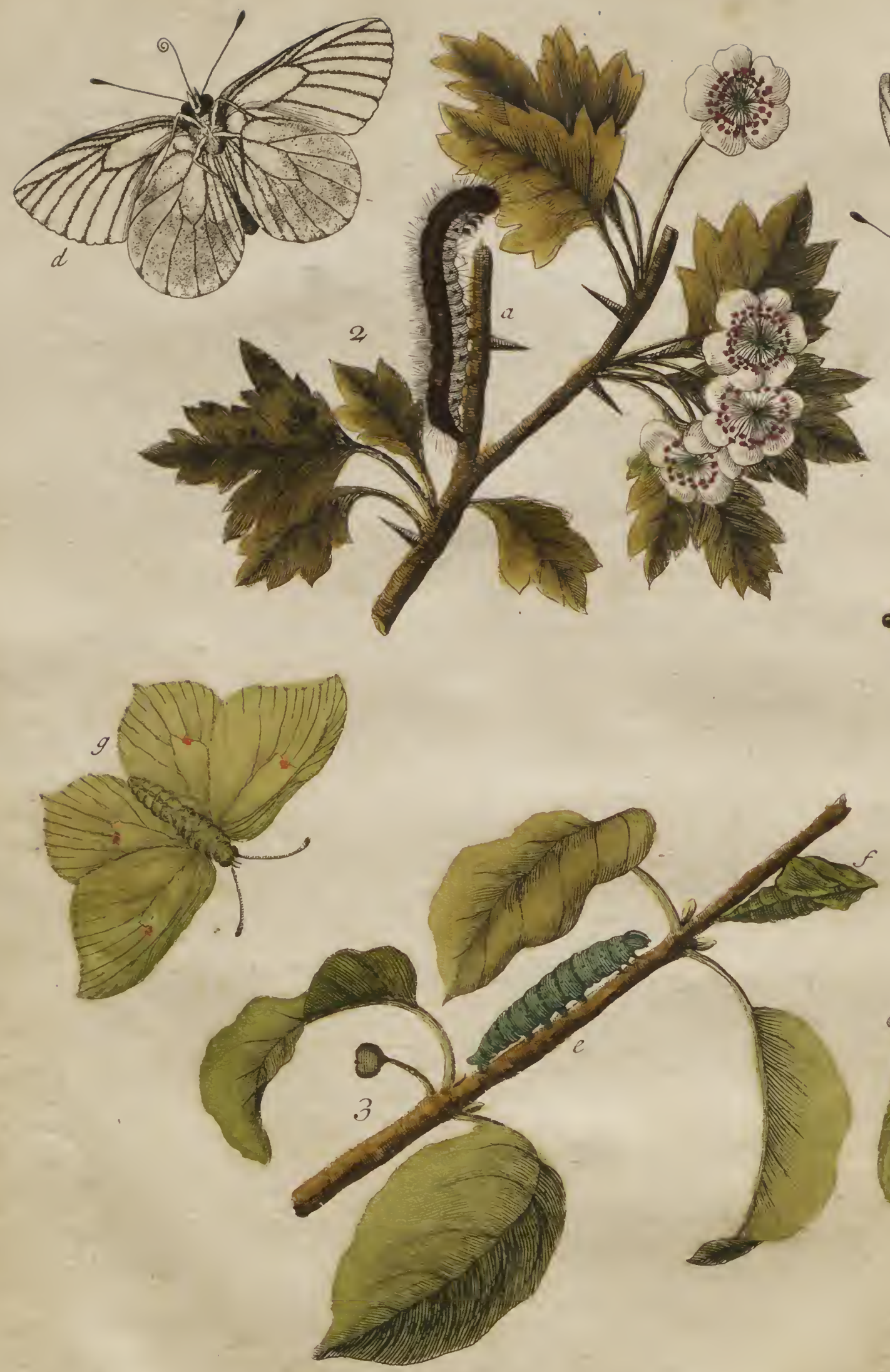

설

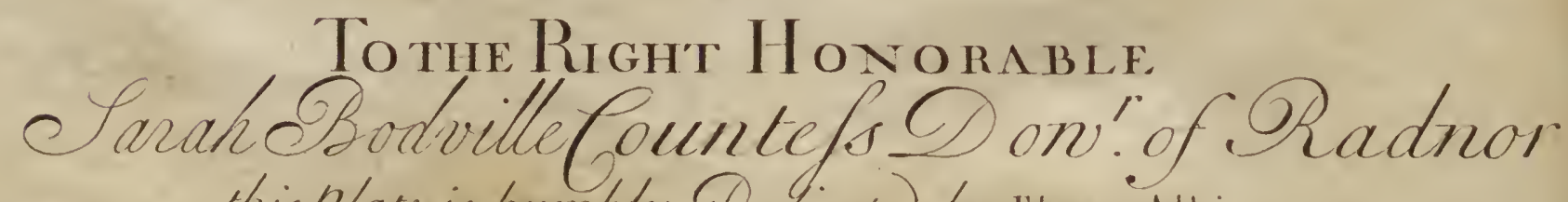 thisplate is humbly Deficaled by Elcazar Atbin.}




\section{Description of the Second Plate.}

THE Caterpiller $a$ in this Plate is Black and $\mathrm{O}$ range-colour on the Back, the Belly and Holders of 'a pale greenifh Afh-colour, with a fmall black Spot on each Joint; the Head and Fore Feet of a deep Black. They are commonly found feeding on the White Thorn at the latter End of April, on which I fed them till the I 2 th of May, at which time one of them tied itfelf up by the Tail and crofs the Middle, after the Manner of the former, and changed into a Cbrysalis, marked $b$ in the Copper-Plate, of a deep Yellow marked with Black, out of which, the firft of Fune, came $P a-$ pilio Albus Venis nigris, the white Butter-fly with black Veins. See Merian, Vol. II. Chap. 35. Moff. p. 103. Ray Hift. Insect, p. I 5 . n. s. Hoff. Tab. 10. Fig. I 4 .

The CATERPILLER marked $e$ in this Plate is of a green Colour, with fmall dark Spots on the Back; the Belly is of a whitifh Green. I took it on the Buckthorn at the latter End of May, and fed it on the fame till the I 2 th of Fune, at which time it tied itfelf up by the Tail and crofs the Middle like the other, and changed into an odd-haped Cbrvalis, $F$, of a green and yellow Colour, as is expreffed on the upper Part of the Branch; out of which, on the 3 oth of June, came $P a-$ pilio precox Sulphurea Singulis alis Singulis maculis, the Brimflone Butter-fly. See Jobnft. Inf.p. 42.n. A. Tab. 5, 6. Moufet. p. 103.n. I. Ray's Hift. Inferts, p. I I2. Hoef. Tab. I 2. Fig. 8. 


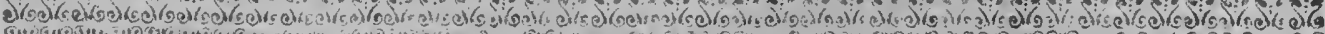

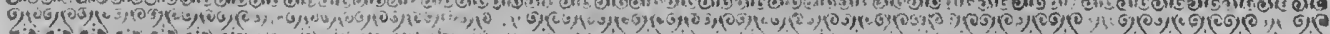

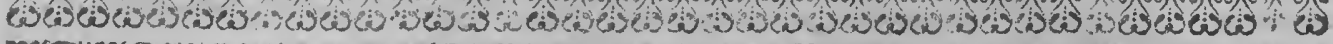
2025)

\section{T H E}

\section{Description of the Third Plate.}

The Caterpiller $a$ in this Plate is black, marked with fmall Specks of White on the upper Part, and on each Side an indented Stripe of Yellow, with black branched Briftles round each foint. The other CATERPILLER, $b$, is marked and briftled as the former, but of a yellow Colour: They feed on Nettles. I found them on the I th of fuly in the Leaves, folded or fpun together: They thelter themflves after this Manner that they may be fecured from the too great Heat of the Sun, Rain, Birds, and a fmall Icbneumon Fly, which often hinders their coming to Perfection. I fed them on Nettles till the 24th of the fame Month, at which time the CATERPILLER hanging itfelf up by the Tail within the fulded Leaves, changed into a Cbryjalis, exprefs'd at $c$, of a Cinereous or Moufe-Dun-Colour, out of which, on the 6th of Auguf, came a mot beautiful Fly called Papillio major Nigricans, alis Maculis rubris $6^{\circ}$ albis pulchre illuftratis, the Admiral Butter-fly. I did not perceive any Difference in the Flies that, were produced from thefe two Caterfillers: Some of their Cbryfalides feemed as if gilded with burnifb'd Gold; out of thefe came a Brood of fmall, but very beauiful Ichneumons. See Goedart, Vol. I. Tab. 26. p. 96. Fig. opt. Lift. Fig. 4. Gr. V. 2.p. 8r. Tab. 8r. Fig. opt. Moff. iоo. mum. 6. an. Hoef. Tab. I2. Fig. is. Mr. Ray. Hift. Infect.p. I 26. 


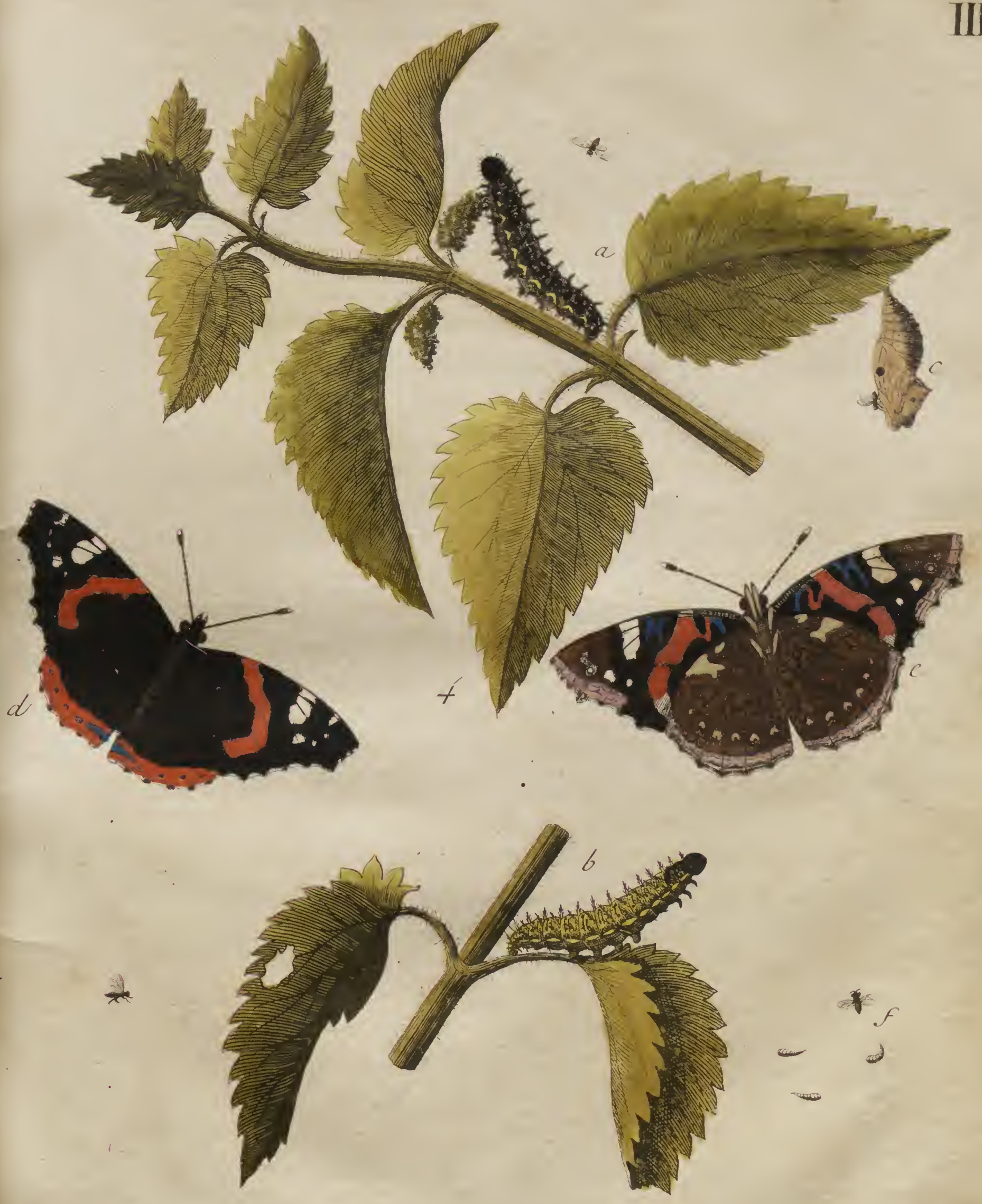

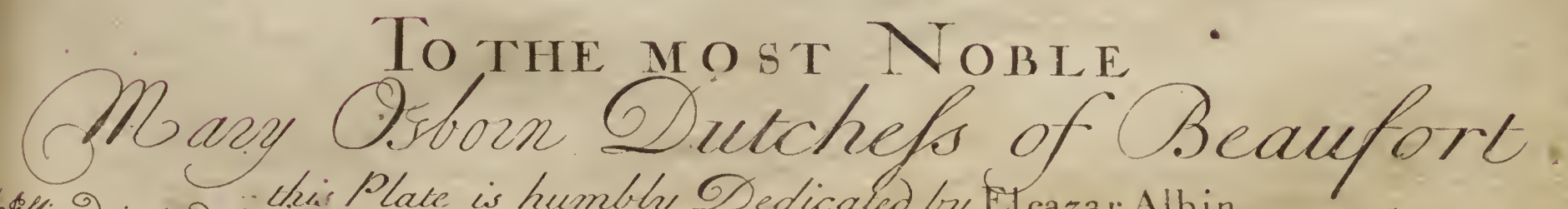

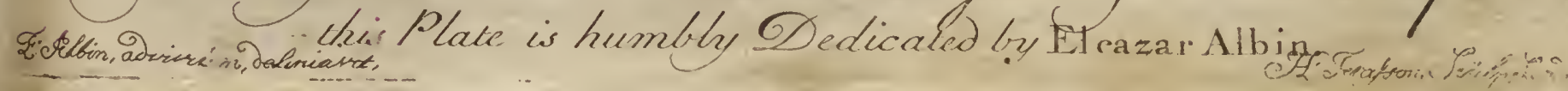




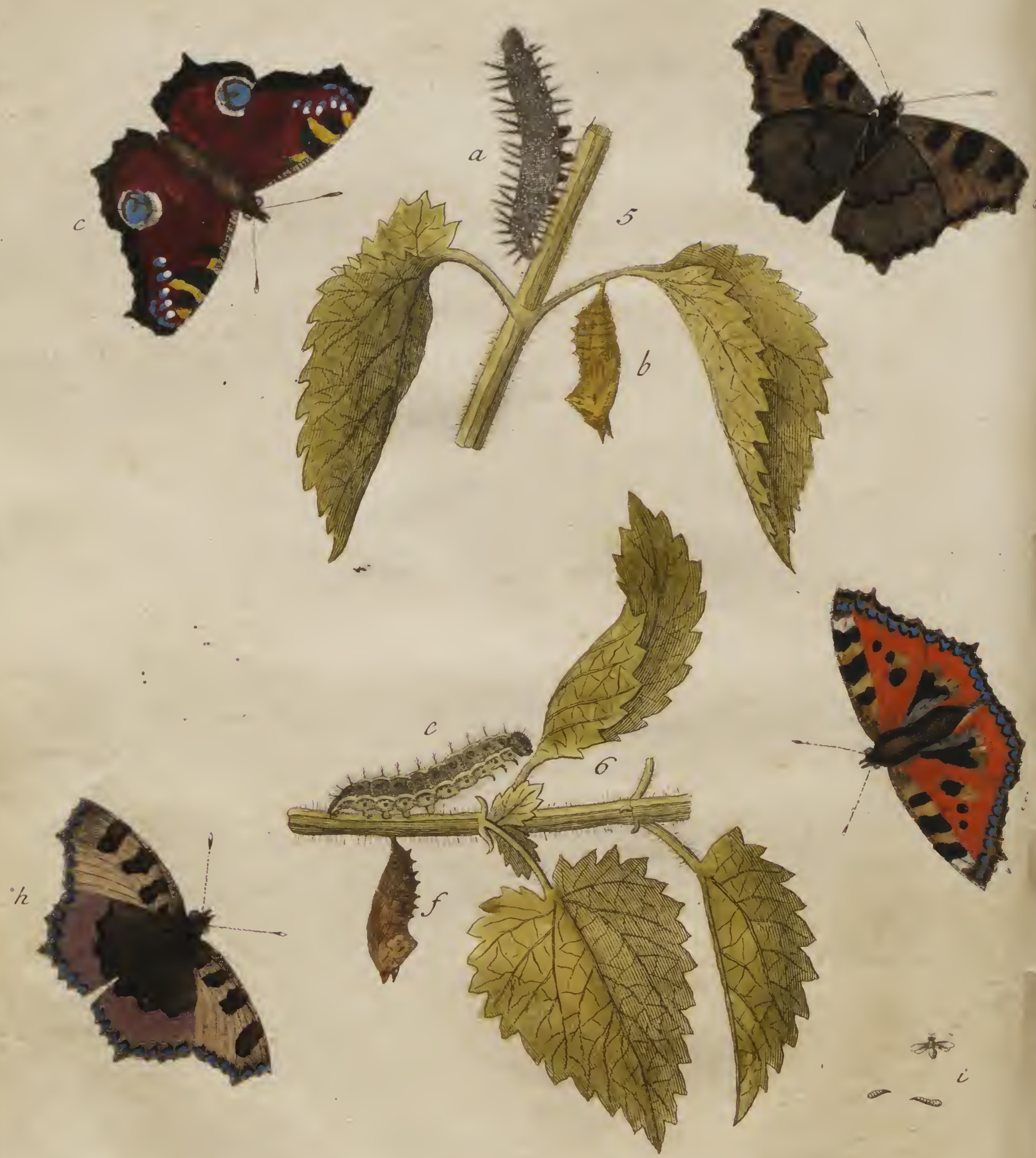

\section{Tothe Hon orable}

Omis Gligatieth otrmerselte this plate is hiumbly, ODedicated by EleazarAlbin. 


\section{T H E}

\section{Description of the Fourth Plate.}

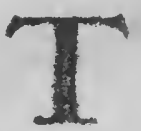

HE CATERPIL LER $a$ is black, and full of fmall white Specks all over his Body. He is one of the branched prickly kind: Its Head is thining, and blacker than the other Parts of his Body; the Holders are of a lighe Brown. It was taken the I th of Fune feeding on the Nettle, ant on the 2oth of the fame Month it tied ittelf up by the Tail, and changed into a Chryfalis of a light Green Colour, and on the 6th of $7 u l y$ came forth a beautiful Butter-fly with Eyes in his Wings, called by Mr. Pettiver, in his Centuria Prima Rariorum Natura, Papilio Ocalus Pavonis dictus, the Peacock's. Eye. This Cater, plllar, when touched, less fall from his Mouth a Drop or two of a dark green Liquor, but for what Reafon I could not judge, it not being hurtful to any part of the Skin where it falls. They are fubject to the fame Production of Icbneumons as thofe of plate No 3. See Goed.Vol. 1. p. 23 Fig. opt. 1. Lift. Fig.r. "Graf. Vol. 1. Tab.26. pag. 53 Ray Hift. Infert p 122. U2. 14. Moufet, p. 99. n. 4 who calls it Omninm kegina, the Queen of Butter-flies. See Hoef. Tab. 12. Fig. opt. 9. Fong. Inf 40. n. 4. Tab.5.

The Caterpilier, marked $e$ in this Plate, is of an Olive $\mathrm{C}_{0}$ lour on the Back, edged with a Stripe of Yellow, and a dark fhining Spot on each Juint. The Belly and Hoiders are of a light Hair Colour fpotted with fmaller Spots. This CATERPILLER Was taken on the 2 th of May feeding on the Nettle, and on the 7 th of Fune fome of them tied themfelves up by the Tail, and changed into a Chryfalis of a light brown Colour, out of which came, in I 4 Days, a Fly called Papilio Tefudiviariss minor, the leffer Tortoife-fhell, from its Wings reprefenting the Shell of that Animal. This Butter-fiy lives all Winter, and hides himfelf in Cottages, old Trees, and other Places of Refuge The Cbryfalides are often found gilded, from whence it was called Aurelia or Chryfalis, which is now become the common Name of the Cafes that Flies lye while in this State. Thefe produced $*$ Brood of fmall $Y$ chnewwions, exprefs'd in the Plare at $i$. See Goed. Vol. 1. p.90. Fig. opt. 2 1 Lift.fig. 2. Graf. Vol. 1.p. 89. Mnff. 101. num. I . figured againlt mum. 12. Hoef. Tab. 2. Fig.opt. 16. Ray,pag. $117, n .1$. 


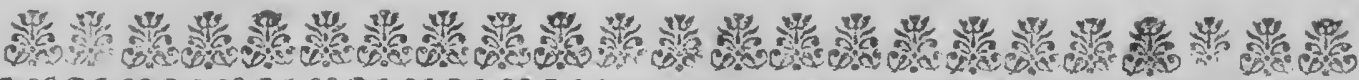

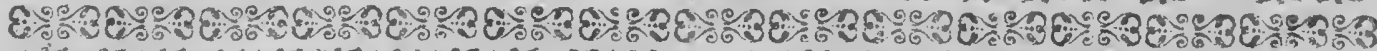
6.

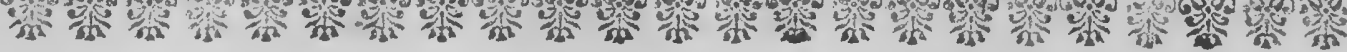

\section{T H E}

\section{Description of the Fifth Prate.}

The Caterpiller $a$ is of a light Sea-green Colour.

1 It was taken near Hornsey-Wood the 8th of Fune feeding on the Black-Thorn, and the 18 th of Fune it tyed itfelf up after the Manner of the white Butter-fly, and the I th of Fuly came forth the Hair-freak Butter-fly. The upper Side of the Wings, marked $b$, are of a dark Brown, with a large Spot of Orange-colour in each upper Wing, and three fmall Spots of the fame Colour toward the Bottom of each under Wing. The under Side of the Wings $c$ are Orangecolour, with large Streaks of dark Red edged with White, and a Shade of bright Red on the Edges of both the upper and under Wings. This CATERPILLAR is very rare, and fcarce to be met with.

The Caterpiller $d$ in this Plate is like the former in Colour, with oblique Streaks of a dark Green on the Sides. His Head is of a yellowifh Brown. It was taken the 4 th of July near New-Crofs in Kent, feeding on the Infice of the Black-berry Buds, making a fmall Hole by which it entered, and eating all the inwärd Part, left the Bud feemingly entire. It fed on them till the I 5 th of $7 u l y$, and then tyed itfelf up after the Manner of the other Butter-flies, and changed into a Chryalis, and the I $3^{\text {th }}$ of Aprizithe Year following came forth a Butter-fly. The upper Siderof atre Wings are of a light brown Colour; the under Side of a beautiful Green. I have found no Account of either of thee Butier-fies in any Awthor. 


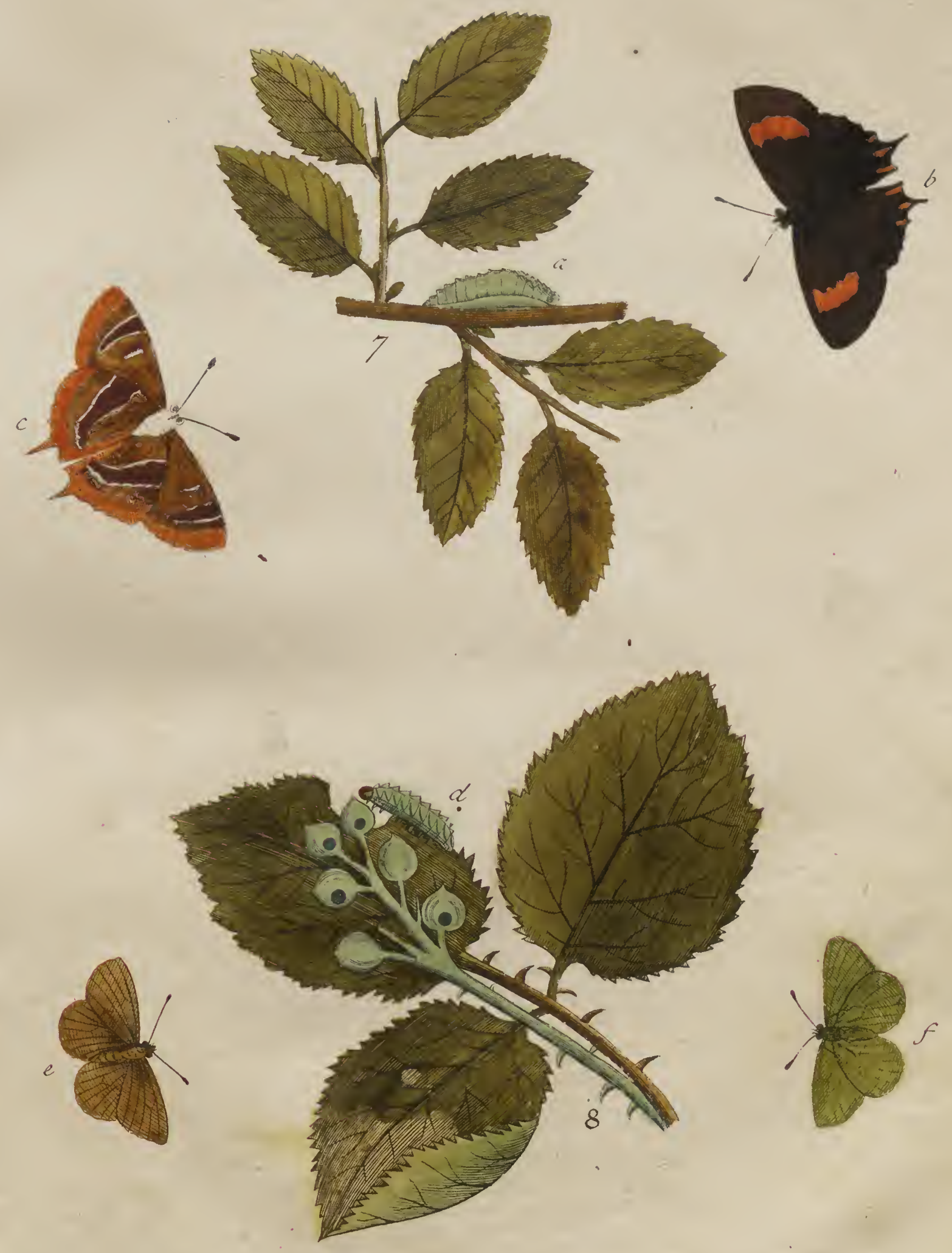

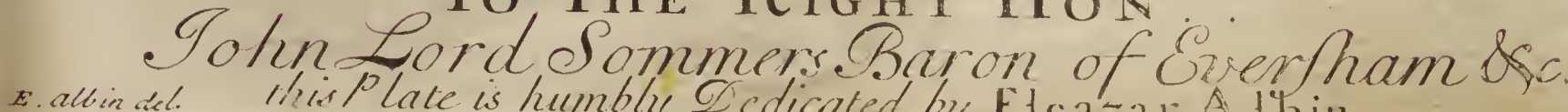

To The R IGHT HoN ${ }^{\text {BLE }}$ 


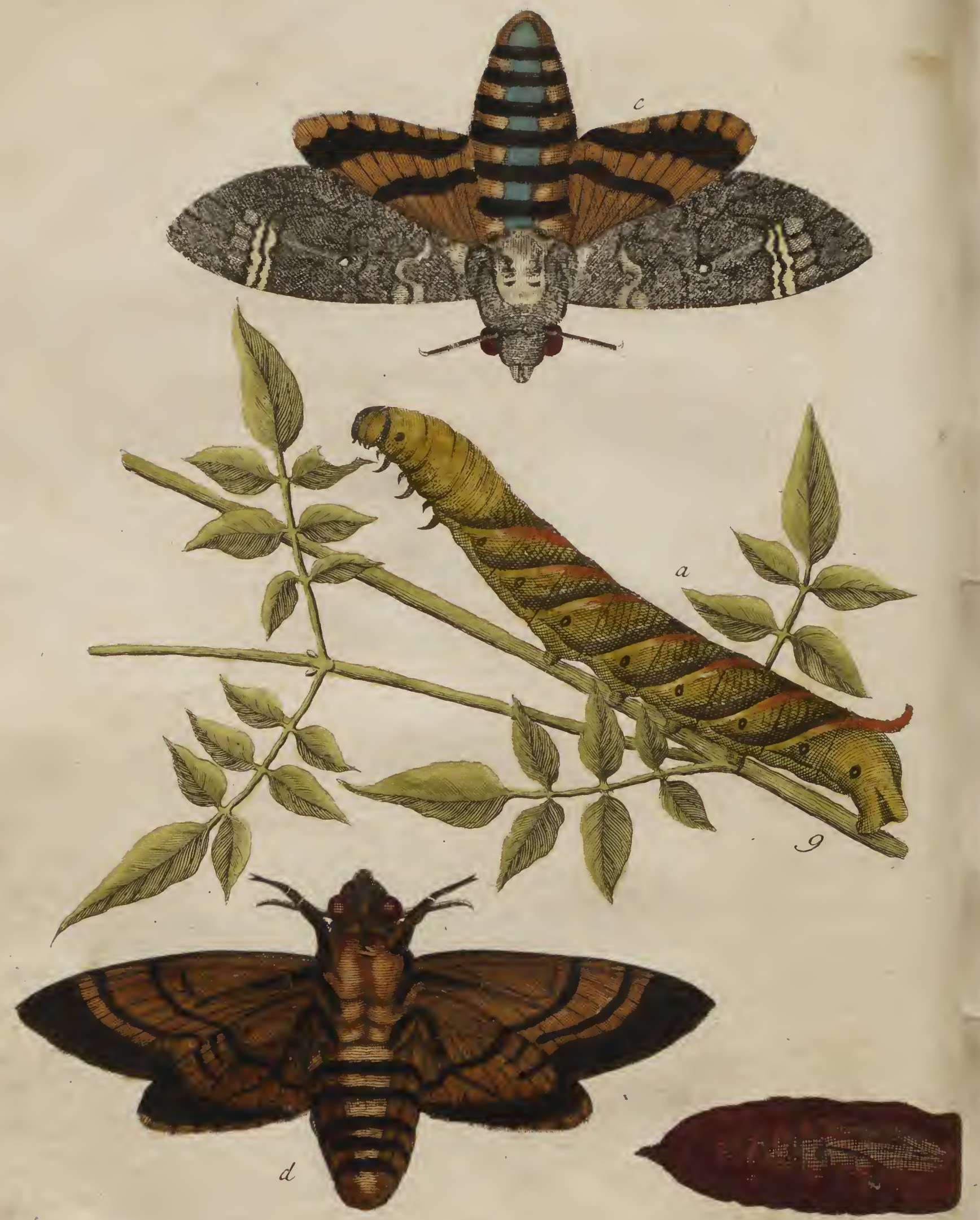

To the Right Honorable

CEnvilita of omersilt Countefs of. Fuffoth s.ulisideden this plate is humbly. Dedicated by Eleazar Albin. 


\section{Description of the Sixth Plate.}

7 His Caterpiller is yellowith, marked obliquely with Orange-Colour Streaks on the Back, which pointing forwards toward the Belly, are of a pale Yellow, and then grow darker in Shade, going backwards till it comes to a Purple, then Orange, $\varepsilon^{\circ} c$. repeated, and fo on for fix or feven Courfes, the laft of which ends with an Orange-colour Shagreen Tail. His Feet and Circle of his Face are black, with Spots of the fame on the Joints of his Body. It was taken about the Middle of Fuly on the Feffamine full fed, and went into the Ground the next Day, and changed into a Cbryfalis of a dark brown red Colour. The Moth came forth at the latter End $_{2}$ of October. There being but one of thefe $\mathrm{C}_{\mathrm{A}}$ TERPILERS, it could not be determined whether that is the ufual Seafon, mott others of the Horn Tail Kind lying in the Ground all Winter till May. - The Back and upper Wings of the Moth $c$ are of a dark Afh-Colour, Atreaked with Lines and Marks of Black, deep Oker, and pale Buff-Colours, and all over this like the fprinkling of fine Flower. The undes. Wings are of a deep Yellow, with two fcollop-edged Streaks of Black acrofs. The Body is of the fame Colours, with a Divifion of Grey inclining to Blue in the Middle, with fix Rings of Black. The Breaft, Belly, upper and under Wings of the under Side of the Moth d, are of a brownifh Yellow, Thaded with a dark brown Colour, as it is exprefs' $\mathrm{d}$ in the Copper-Plate. Thefe CATERPILLERs are very rare to be found neither have I found them defcribed by any Author. 


\section{TH E}

\section{Description of the Seventh Plate.}

His Caterpillar is of a yellowith Green, the out Circle of the Face of a deep Purple: He had feven long pointed Stripes of Purple and White on his Sides obliquely thwarting each Joint, with a Spot of deep Orange under each: The Horn on his Tail is yellow, tipt with Black. It was found the 4th of Auguft on the Lilac, very large (they allo feed on Priwet, Holly and Phillyrea;) it went into the Ground the sth of Auguff, and in five Days changed into a Cbrysalis, having fult changed its Skin, which 1 have obferved them to do four times in their Courfe from the Egg to the Chryfalis. It remained in that State all Winter till the 26 th of Fune, at which Time came forth the Moth expreffed at $c$ and $d$, commonly called the Privet Hawk-Moth. The upper Wings are of a light Brown with dark Shades, having a Crols and feveral-Lines of Black in each. The Body was of a light Brown, marked on each Side with Role-colour and Black alternately. The under Wings are of a pale Rofecolour, with crols Stripes of Black. The Eggs are of a pale green Colour; they hatch in a few Days after they are laid. I had one that laid about fixty Eggs, which came all to Perfection. From one of thefe CATERPIL LARS taken in the Fields was produced a very large Ichneumon, the Body and Tip of the Tail were Black, the Legs and other Parts of a deep Yellow, the Wings and Horns tipped with a Shade of Black. We eafily find thefe and moft other large CATERPILLARS by feeing their Dung under the Tree or Buth on which they feed. See Ray's Hift. Infect. p. 1 44.n. 1. Moufet, p. 91 . n.s.p. 182 . ch. 2. defcribes. the CATERPILLAR; lo doth Mr. Ray, p. $x 45$. 


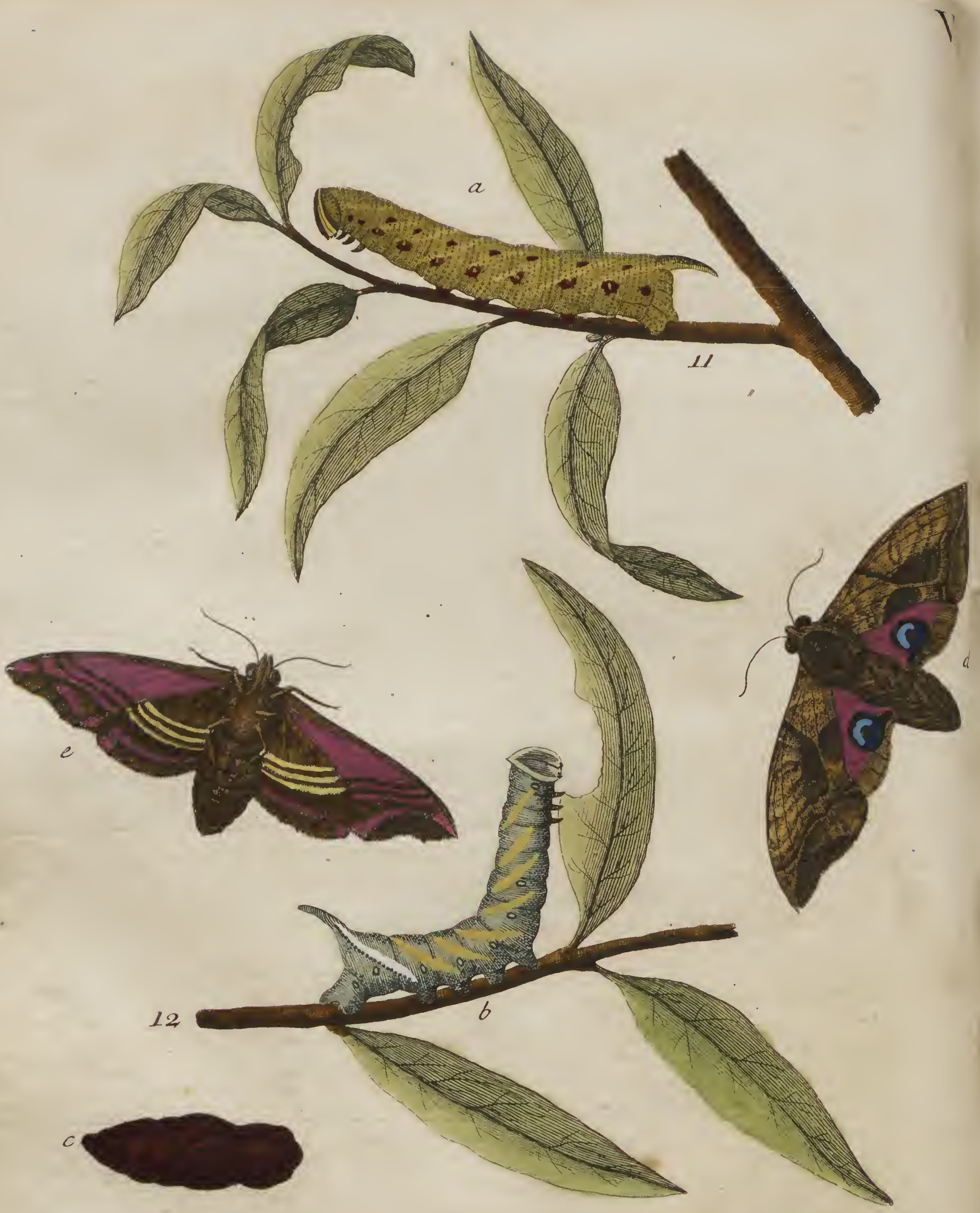

\section{To the Ho norabie}

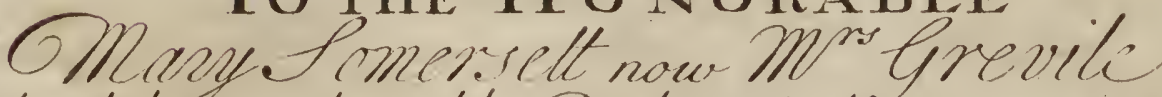


T H E

\section{Description of the EighthPLATE.}

THE CA T ERP I L I R $a$ is of a yellowith Grcen, with oblique yellow Stripes on his Sides, fpotted with a double Row of crim-
fon Spots; the Holders and Feet of the fame Colour of the Spots, the Horn in his Tail blueilh. It was taken the $23 \mathrm{~d}$ of Auguf on the Dutch Willore, in the Marfhes near Rotherbitb: I fed them till the 7 th of September, at which time fome of them went into the Earth which I had purpofely put at the Bottom of the Box in which I kept them, and changed into a Clory falis expreffed at $c_{\text {. }}$ (Some of thefe fpotted CATERPILARS that were taken the 2 Ift of Auguf I 74 ; remained alive in the Chry falis till the 4 th of May 17 r6.) And Mr. Derbam hath obferved, not only thofe of the Butterfly and Moth Kind, but many other Tribes alfo, to lye long in

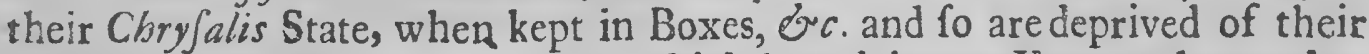
natural way of Hatching; fome of which have lain two Years and more before they have broken Prifon and flown abroad, and fome have in that time been dried up in their Cbry falides, and others that have arrived to their mature Infect State, not being able to make their way out, have perithed in their Cafes.

The Caufe of all this is, no Doubt, the want of thofe kindly Impregnations, Humectations, and Nutriment they meet with in the more natural Beds they make themfelves in the Earth or open Air, to which the great Author of Nature hath fo admirably adapted the Bodies of thofe little Creatures, that no Weather, no not the fevereft Frofts, can hurt them. Of this many Examples might be given in almoft every Tribe; but that of Dr. Lifter, in his Note on Goedart's 26th, Thall fuffice, who faith, That in the Middle of Winter be bath found both Caterpillars and Hexapod. Maggots on the Snow, which were fo frozen, that they would rattle in a Glaf's like Stones; but being thawed and warmed, would creep briskly about, and try to make their Efcape.

The CATERPILLAR $b$ is of a blueilh green Colour with yellow Stripes, except that next his Tail, which was white, edged with a fmall Row of black Spots, it had a fmall crimfon Circle on each Joint: His Fect, Holders, and Circle of the Face were of the fame Colour as the Body. It was taken the I6th of July on the Willow-Tree, on which it fed till the 27 th of the fame Month, at which time fome of them went into the Earth, and changed into a Cbryfalis, and the 5 th Day of May the Year following came forth a moft beautiful Moth with Eyes in its under Wings; "tis commonly called the Eyed Hawk-Moth. One of thefe C A I E R P I La ARs, before its time of Change, had feveral Maggots come out of his Sides, which fpun themfelves Cafes of a brown filky Subltance, and the Summer following produced frnall Ichneumon Flies: The C A T ER P ILL A R lived fix Days after the Eruption of the Maggots without eating. See Lifter's Goedart, n. 24. Merian, Vol. 2: Chap. 37. Ray, pag. I48. 1. 2. Moufet, p. 9 I. n. 6 . 


\section{Description of the Ninth Plate.}

THE CATERPILAR a is greenifh, fpotted with Black, 1 having two Spots like Eyes on each Side the Body near the Head; the Horn on the Tail was tipt with Black: When he is difurbed, or has done Feeding, he draws in his Head like a Torroife.

The CATERPILAR $b$ is of a dark Brown, with Rings and Streaks of a lighter Colour, the Horn on his Tail tipt with Yellow, in every thing elfe like the Former. They were found the $26 \mathrm{th}$ of Fune on the white Lady's Bedftraw in the Marfhes, on which I fed them till the 7 th of $f$ uly, at which time fome of them fpun themfelves up in the Leaves of the Bedfraw, and changed into a Chrysalis, and the isth of April following came a moft beautiful Moth of an Olive-green and Rofe Colour, prettily intermix'd on both Sides. One of thefe C A TER P I L A R s being Ay-blow'd the Spring following, came forth an Ichneumon, expreffed at $g$, whofe Body was Black, and fpotted with reddifh Brown. I obfer-

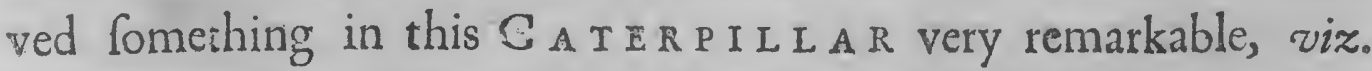
his Dexterity in $S$ wimming; for commonly Feeding in or near the Water, if at any time he happens to fall in, he turns himfelf on his Back, and fwims with his Head and Tail turned together till he gets Hold on fome Part of the Plant, by which he helps himfelf up again. The CATERPILLAR $b$ I take to be Goedart's 26 th, which he calls the Elcphant. See allo Ray's Hiff. Insects, po 1.45. 2. 20 


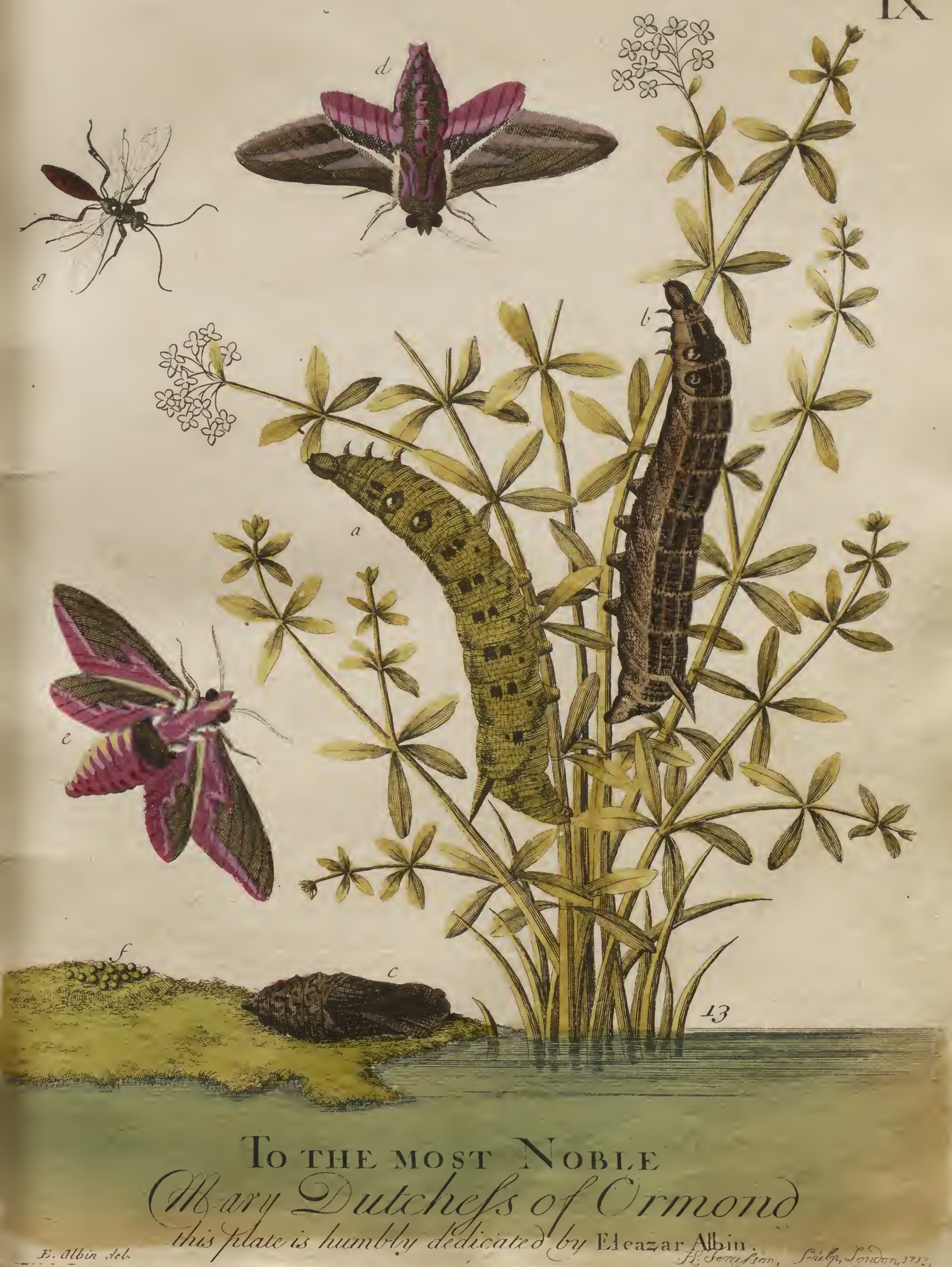




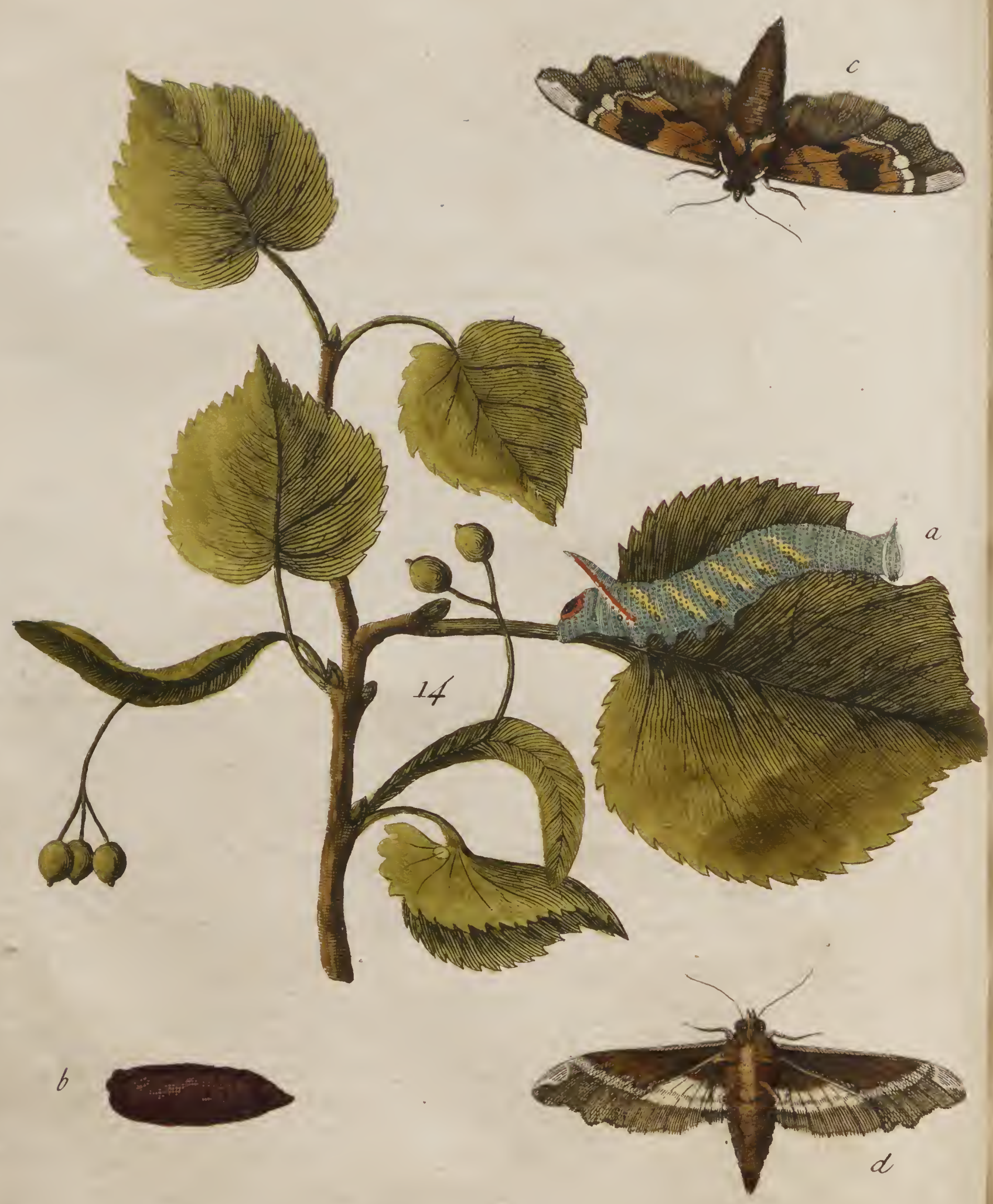




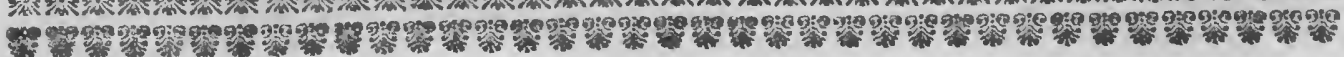

\section{T H E}

\section{Description of the Tenth Plate.}

This Caterpilitar is of a blueih Green, full of 1 white rifing Specks: It has yellow Stripes on his Sides, the hindermolt of which extending to the under Part of the Horn on its Tail, ends there in Orange-colour, having a Circle of the fame Colour juft below it. (I have likewife found fome of then with two Rows of Crimfon Spots on their Sides, and of a yellowith green Colour, like the CATERPILIAR a in Plate the 8th.) This was taken the $\mathrm{I}>$ th of Fuly on the Lime-Tree, on which I fed it feveral Days. Before it changed into a Chryfalis, it turned purplein on its Back, and the Belly pale Liver-colour; the Horn on his Tail of a deep Blue, the Orange-colour and white Specks remaining very pale. It went into the Earth the $22 \mathrm{~d}$ Day of $\mathcal{F} u l y$, and changed into an Aurelia or Chryfalis, and remained in that State till the Is th of April, the Year following, then came forth a beautiful fcolop'd-wing'd Moth, having a curious Mixture of Olive-green and Peach-colours in his Body and Wings: Their Eggs are of an oval Shape, and green Colour. I never found thefe CAIERPLLIARS fo numerous, as to hurt the Trees. This CatERPILLAR feems to be more like Goedart's $2 \mathrm{~g}$ th, than that in Tab. 7 : He faith the Horn in its Tail is poifonous, and that it defends it felf therewith as with a Sting: I have obferved feveral of thefe Tribes, and others that have not thefe Horns or Bunches, to thake or turn themfelves when any Fly or Icbneumon fettles on them. See Merian, Vol. 2. chap. 24. 


\section{$\mathrm{TH} \mathrm{E}$}

\section{Description of the EleventbPlate.}

HIS CA T BRPILLAR hath the Belly and Sides of a yellowith Green, with a fmall white Spot on each Joint; the Back is of a 1. blueith Green fpecked with White, and is parted from the yellow Grcen by a white Sireak continued from the black Spots (reprefenting Eyes) to the purple Gibbofity on the Back, from thence paffing obliquely down the Sides to the firf Pair of Holders, where it is interrupted by a deep Purple, and rifes again about the fecond Holders, and ends at the forked Tail. From the purple Gibbofity on the Back and purple Iaterruprion on the Side, a Shade of Purple is continued all along the upper Part of this white Streak. It has a deep purple Streak on each Side the Belly, There are fometimes white Circles and purple Spots on their Sides, which feem to be accidental, for in all I have feen they have varied. The out Circle of the Face is of a bright Yellow, the fecond of a deep Rofe-co. lour, the third Black, and the middle of a Peach-colour. His Head llike that of a Tortoife) was put forth and drawn in at Pleafure. The Fore-feet were of an Afh-colour, as was alfo the forked Tail, and fpeckled with Black. "When it is difturbed, it thrufts out of its Fork two fcarlet Tips or Points, in an angry Manner, as a Defence, but I could not perceive they were hurtful; having feveral times applied my Hand to them, I found them foft, and the CA TERPIL L A protrudes or retracts them as he pleafes with great Facility. Thefe CA TERPILLAR $S$ are found on the Willow and Popler Trees from the latter End of 7 une to the Middle of Augufl. In four or five Days after I had taken them, they made themfelves, by gnawing the Wood of the Box into fmall Bits like Saw.duft, a hard $\mathrm{Cafe}$, working it with a glutinous Matter which their Bodies afford, as it is expreffed at $b$, in which it changed into a Chry falis, marked $e$. The Motb came forth in May; $d$ reprefents the upper, and $e$ the under Sides of it, being of an Alh-colonr, ftriped and fpotted with Shades of Black. The Fggs, marked $f$, are of a pale Liver-colour, their under Side flat, and the upper Side rifing in a conick Figure. I obferving feveral of thefe $\mathrm{C} A$. TERPILLARS to have Eggs or Fly-blows fticking on them, I plucked them off from fome, and left them on others, to fee the Event : The firft produced Moths, the others Maggots, which ftick faft to the C A I E R PILLARS by their Tails, which are in thining Cafes about one fifth Part of their Length. They pierce his Body with their Probofcis, which is fmall and tharp, thereby fucking their Nutriment from him. I plucked fume of their Probofcis out of him, they ftill remaining faft by their Tails in the Cafes, and they after fome time penetrated him as before. Thefe Maggots made themfelves Cafes of an earthly Colour, expreffed at $g$, and in May the $Y$ ear following produced the Ichnewmon expreffed at $b$, being of a light brown Colour. See Lifter's Goedart, n. 20. Moufet, p. I83. who calls the Catrerilzar Eruca Vinula: i. e. the Beau; fo doth Mr. Ray from him, pag. 153, where both the Moth and Caterpillar are well de. fcribed. 

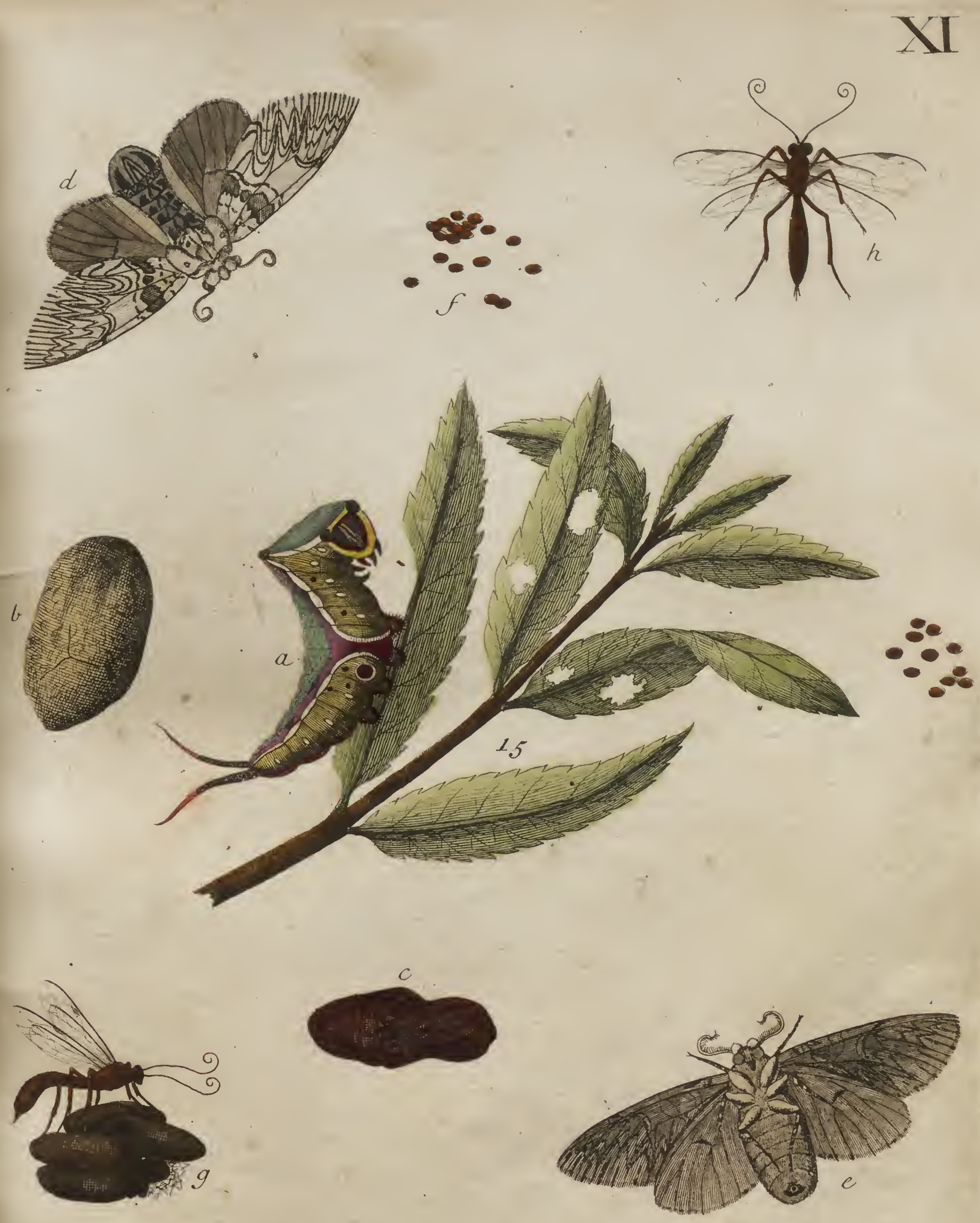

\section{To the most Nobi.e}

Mary Gapell Oulchefs OD on. Of Beaufort this pitate is humbly Odedicatid by Elera zar.Albin.

E. Albin delin.

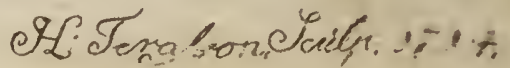



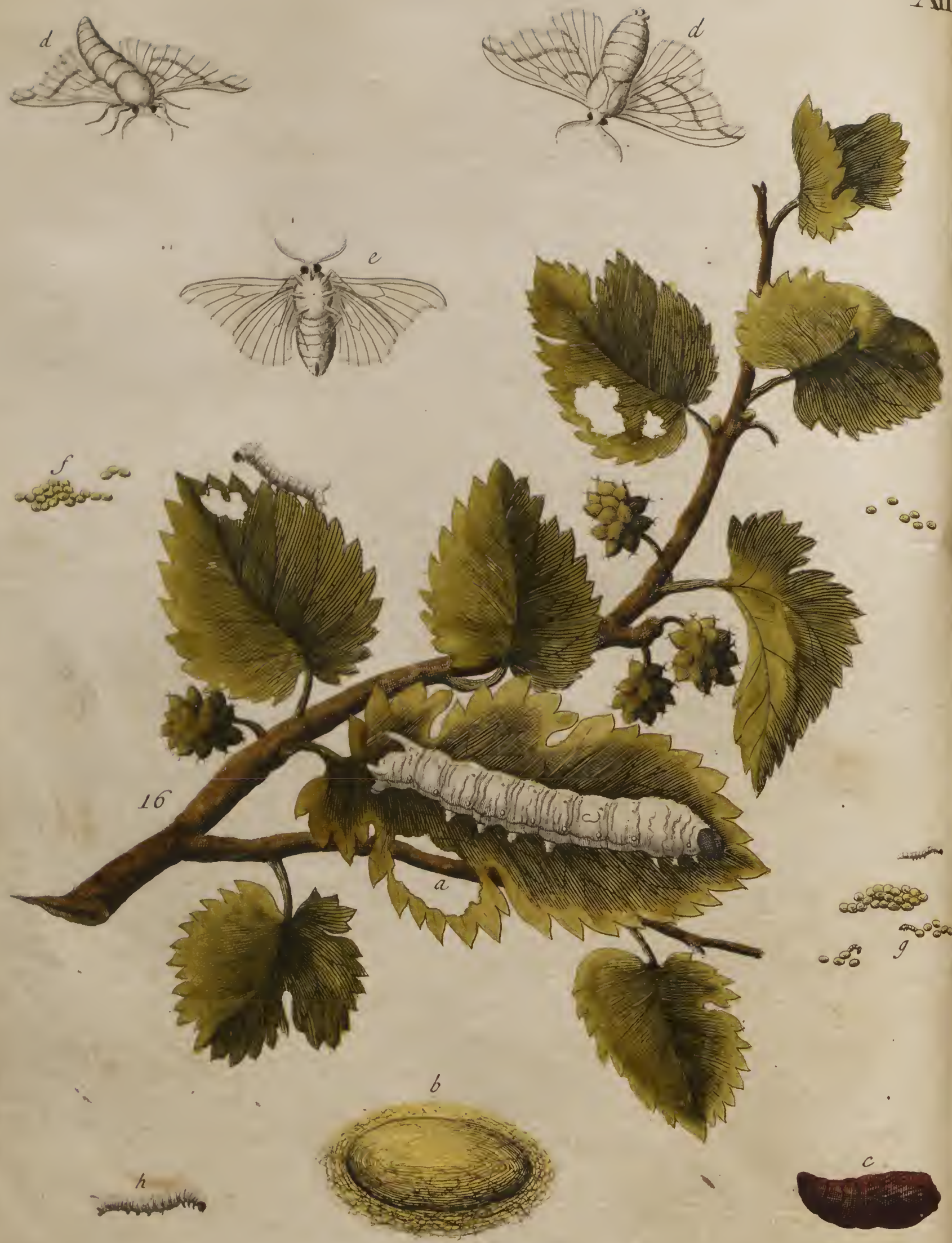

\section{To the mos't Noble}

Gluny Dutchefer gon: of Bedford 


\section{T H E}

\section{Description of the Truelfth Plate.}

$\mathbf{T}$

HE CA TERPILLAR (commonly known by the Name of the Silk-worm) is of a pale Cream-colour inclining to White, with fmall dark Circles on each Joint, and two half Circles on his Back. They are hatcht from Eggs of the preceding Year in May, and being put on convenient Boards, are placed in an airy and temperate Room, and fed twice a Day with frefh Mulberry Leaves. N. B. If the Mulberry Leaves are not put forth, you may feed them at firft on Lettice or Succory Leaves. They muft be kept very clean and dry; fome rub the Boards on which they lay them with Wormwood, and fprinkle it with Wine, and then dry them well before they put them on again. Notwithftanding this Care, they are fubject to feveral Difafes, which often obliges fuch as keep them to remove them for Change of $\mathrm{Air}$, and fometimes to perfume the Room with Incenfe, Benjamin, and Vinegar. They are to be defended alfo from Cats, Birds, Ants, and Flies; they fuffer likewife by Lightning, Thunder, or any harfh Sound. They feed about 40 Days, during which time they change their Skin four times, not eating for fome time before each Change. When their time of Spinning draws nigh, which is known by their being tranfparent and reftlefs, they are put in little Coffins of Paper, rouled up like a Wafer, and pinned up againft a Wall, or Hangings of a Room. N. B. In Spain

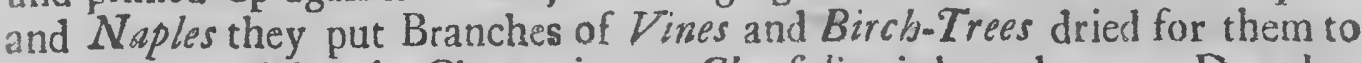
fpin up in. After its Change into a Chrysalis, it lyes about If Days before the Moth comes out, which is reprefented in the Copper-plate at de, being of the fame Colour with the CATERPILAR, the Male having a lefler Body and broader Horns than the Female, as molt of the Moths of the Male kind have. After they have purged themfelves, they couple and lay Eggs, every Female laying near 160 , which are firft Yellow, and after of a Liver-colour. Mr. Derbam makes Mention, in his Phy fico-Theology, pag. 388, of an ingenious Gintlewoman who had the Curiofity to meafure the Silk that compleated one of their CaJes, which was found to be above 300 Yards, and weighed but 2 Grains. If you have not time to winde them off prefently after the Cafes are compleated, put them in an Oven afer the Bread is drawn, letting them ftand fome time: This kills the Moth, which would elfe eat her way out, and fpoil the Silk; you may then keep them as long as you pleafe. See Philof. Confer. of the Virtuof. of France, Vol. 2. p. 402 . Goedart, p. 1. Tab.42. Merian, Vol. 1. p. I. Malpighi de Bombyce. 


\section{T H E}

\section{Defcription of the Thirteenth PLATE.}

THE, CATERPILLAR $a$ is of a pale Blue, having 3 fquare fpots of Yellow on each Foint, and on each of them 4 fmall black Spots; it hath 2 large Spots of Black on the Head, reprefenting Eyes. It was taken the $22 \mathrm{~d}$ of May on the Black Thorn; it likewife feeds on the White Thorn, Bramble, and Crabtree. The 27 th of May it fpun it felf up in a Cafe $b$ on a Branch of its Food, in which it changed into aCbryfalis $c$. The 26 th of Auguft came forth the Moth, the upper fide $d$ Brown and Afh-colour'd, with a double Spot of a Yellowith White like a Figure of Eight in each Upper Wing; the under fide of the Motb $e$ is of a light Hair Colour.

The Caterpillar $f$ is White, and fpotted with Black and Yellow all over the Body, Feet and Holders; the Head Yellow fpotted with Black. It-was taken on the 2oth of May feeding on the Water Betony; it alfo feeds on the Mullein: The 3 oth of May it went into the Earth, which I had provided at the bottom of the Box, in which I fed it; and made a hard Cafe, expreffed at $g$, of the Earth and a Webby Matter near a quarter of an Inch thick, to fecure it felf from the Injuries of the Weather, $\sigma^{\circ} c$. In this Cafe it changed into a $C b r y f a l i s ~ b$ of a Tawny red Colour, and at the beginning of March following came forth the Moth, i, of a Buff Colour thadowed with dark Brown. Some of thefe Caterpillars were Flyblown, each of which produced 5 or 6 dark red Chryfalides $l$, from each of them came the Fly expreft at $m$. See Ray's Hift. Infects p. 168. n. 25. 

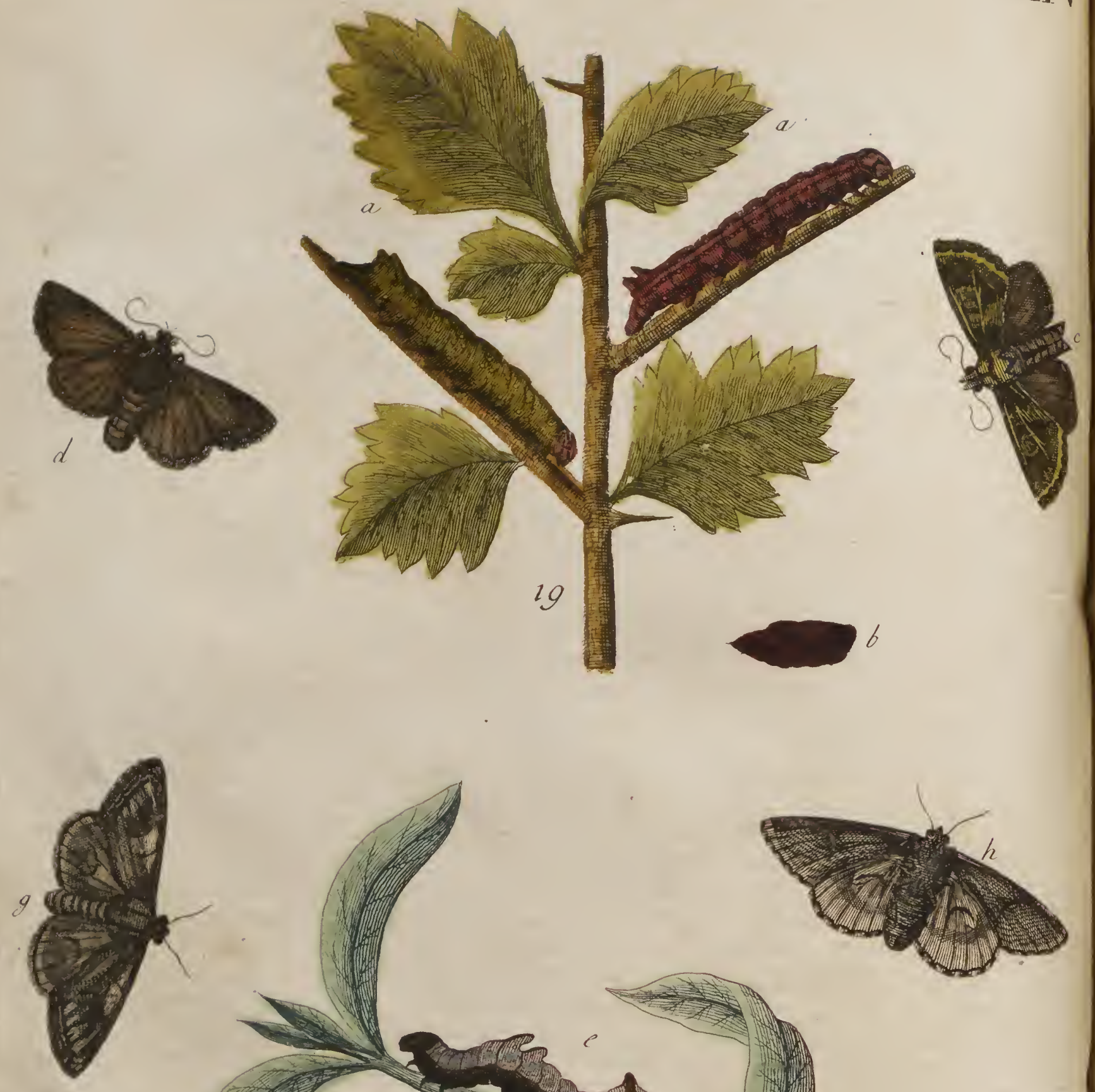

To THE MOST: NoBI.

chenry Dulic of.Beaufort this filake is humbly Ocdirared by. Elcazar Albin. 
19.

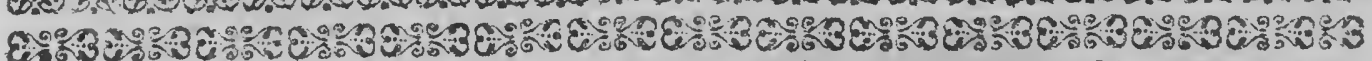

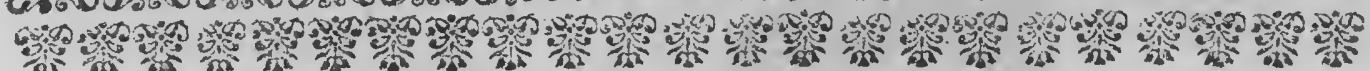

\section{T H E}

\section{Defcription of the Fourteenth PLATE.}

$\mathbf{T}$

HE two Caterpillars a a are of the fame Species, altho' of different Colours, the uppermoit of which was of a reddilh Colour intermixt with Green and darker Shades, the lowermoft was Green and Clouded like the former but without any Red; they were both fpotted with White Specks, circled with Black all over their Bodies, and had two Rifings or Bunches at the Tail. I always found them in the Pofture they are drawn in, clofe to the Stem, except when feeding. They were taken the r 7 th of May feeding on the White Thorn; they alfo feed on the Black Thorn and the Crab-Tree. The $22 \mathrm{~d}$ of the lame Month they went into: the Earth in the bottom of the Box, and changed into a Chryfalis of a reddifh Brown Colour expreffed at $b$, and about the middle of September came forth the Moth $c$ : the Upper Wings were a mixture of reddifh Brown and Buff Colours and over all Lines of a light Green; the Vnder Wings and under Side $d$ were of a pale Ruffet Colour.

The Caterpil Lar $\boldsymbol{e}$ is of a reddifh Purple Colour, with Blue Spots and fmall Black Circles on each Foint, it had 2 Rifings on the middle of its Back, and one at the Tail, with 2 large Spots of Orange-colour below it: It always ftood in the Pofture figured in the Plate, with its hinder part lifted up from the Branch, except when moving or feeding. This CATERPILLAR was taken the gth of Fuly feeding on the Dutch Willow in the Marfhes near Rotherbitbe. Before its change the rifings on the Back and Tail fell in, and the whole Body turned blackifh: It fpun it felf up in the Leaves, I had anotber which buried it felf in the Earth in the fame Box. They both changed into Chryfalides as $f$ expreffes, towards the middle of Fuly; and the beginning of Auguft came forth the Motb $g$ of a light Brown Colour heightned with White, and Streaked with lines of Black. Godartius feems to defcribe the firtt of thefe n.23. and the latter n.22. and calls it the terrible Eruca; the rifings on the Back he faith are a Guard to defend himfelf. See Lifter's Godart w. 2 r. 


\section{THE}

\section{Defcription of the Fifteenth, PLATE.}

\section{1}

He Caterpillar $a$ hath its Head and Back of a light brown Colour, the Belly of a light Hair Colour, parted from the brown by an indented Line of Black, edged with White. It was taken feeding on a Peach-tree, in a Garden at Hackney, the 2 Ift of May; and the 25 th of the fame Month it went into the Earth in the Box, and changed into a Cbrysalis $b$; and at the latter end of Fune came forth the Moth expreffed at $c$, the upper fide brown, with lines and circles of White in the upper Wings, the under fide $d$ of the fame Colour, with a border of light Hair Colour, divided in the middle by an Ingrail'd line of Black. This CATERPILLAR I have rarely found.

The Caterpillar $e$ is of deep 'Tawney, with a row of Cherron-like black Streaks all along the Back, the Angles pointing towards the Tail, with fome dark Spots on its fides. It was taken on the Oak the $4_{4}$ th of Fune near Dulwich; fome of the fame have been taken alfo near Woolwich in Kent, others in Canewood near Hamftead. It went into the Earth the $24^{\text {th }}$ of Fune, and changed into a Chryjalis $f$; and about the middle of Auguf came forth a beautiful Moth, expreffed at $g$, the Back and upper Wings of a deep Orange Colour, the Belly and under Wings of a Cream Colour, with faint Shades of Orange and Streaks of Rofe Colour, 


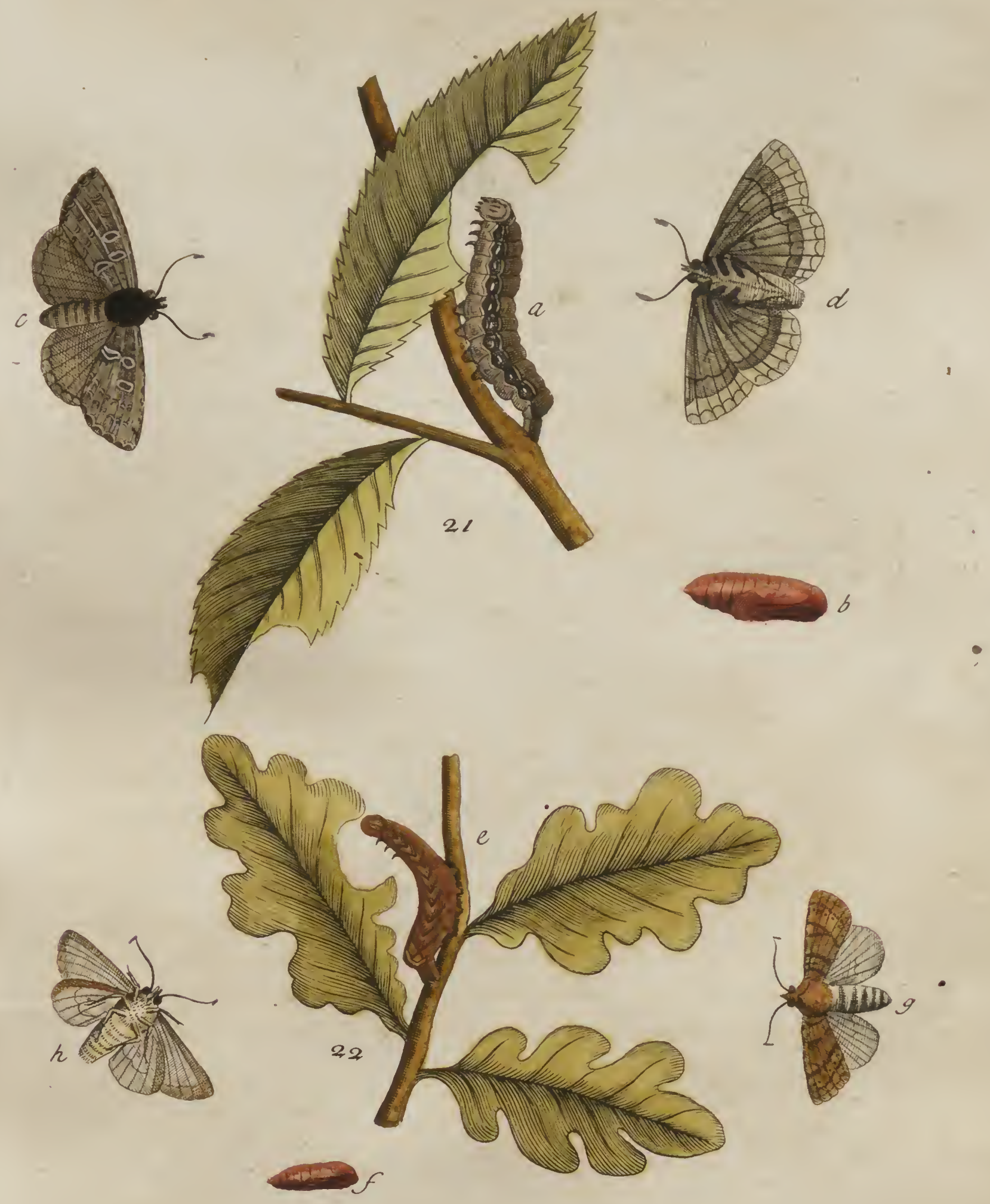

To the Right II oxo rable

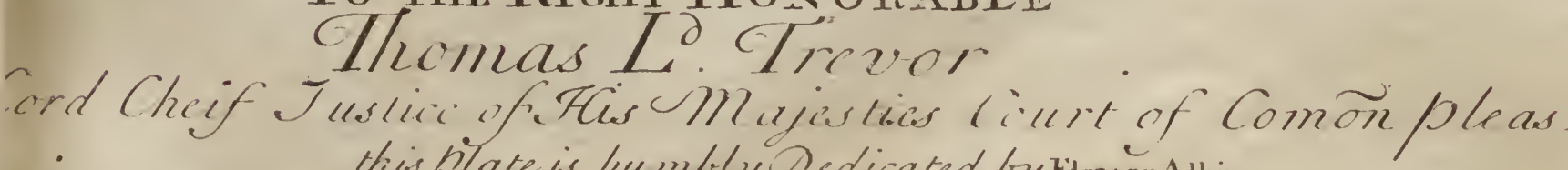
this plate is humbly bedicated ly Fieazar Albin. 


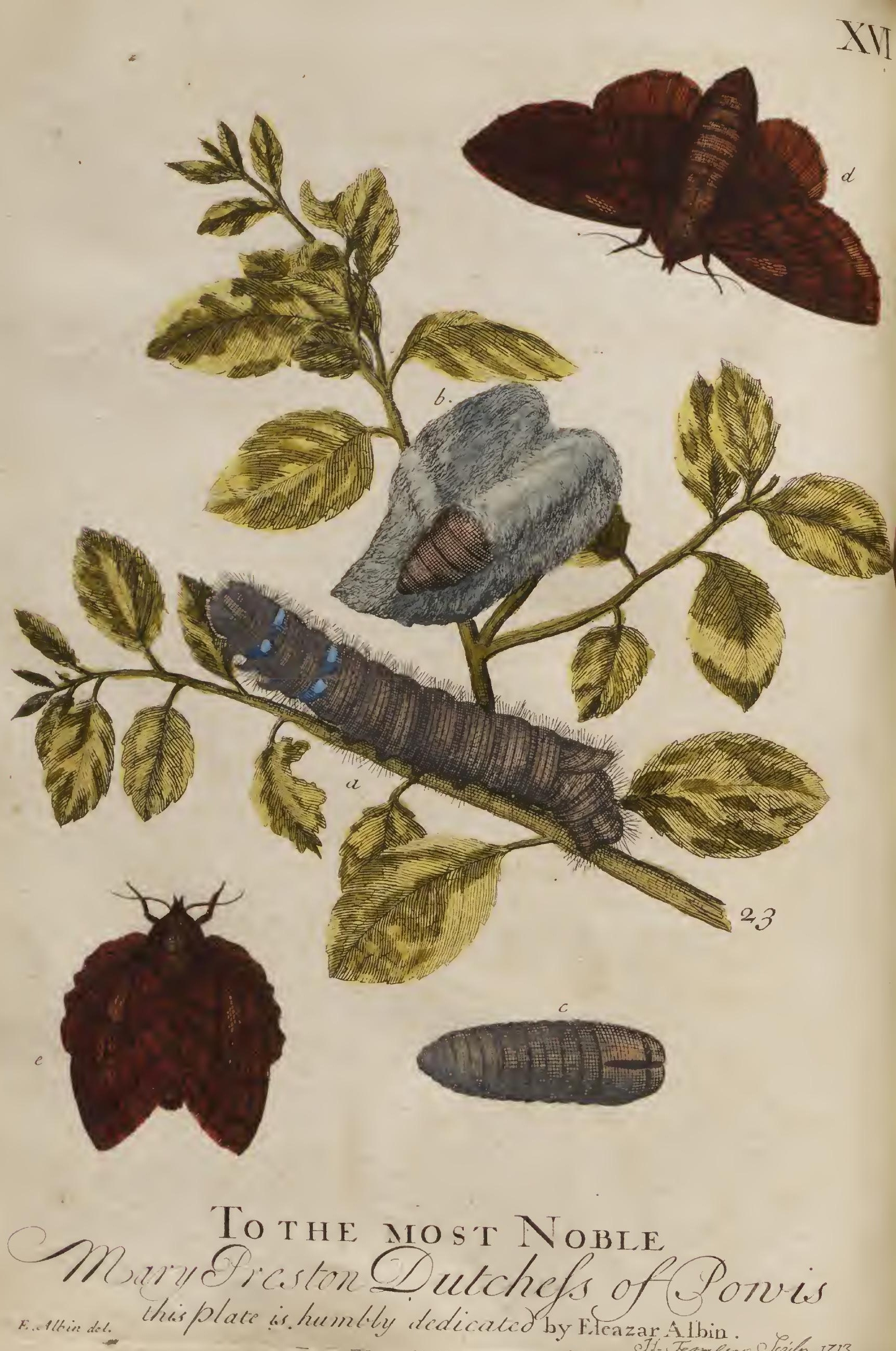




\section{TH E}

\section{Defcription of the Sixteenth Plate.}

THE CAterpillar $a$ is of a dark Purple Colour with a mixture of Red and Brown, it hath 4 Blue Spots on its Back near the Head, it had Flaps or Lappets on every Foint, which makes him appear to have fo many Feet. It was taken on the Alaternus about the middle of May; it alfo feeds on the Lauruftinus, Black Thorn, White Thorn, and Bramble. On the 28th of May it fpun it felf up in the Leaves in a Greyifh Silkey $W e b$ as $b$ expreffes, and Changed into a Cbryfalis $c$ almoit of the Colour of the CATERPILLAR, and on the 2 ift of $7 u l y$ came forth the Moth $d$ of a reddifh Colour with three Ingrailed lines of Black acrofs the Upper Wings, and two of the fame in the Under Wings; the under fide of the Moth is of the fame Colours: the Eggs are White and itreaked with dark Green: the young CATERPILLARs. live all the Winter. I have fed them on the Bramble till the latter end of April, and then given them. White Thorn and Black Thorn to feed on, and brought them up till their Change. The Moth in its fitting Pofture is reprefented at $e$, which is particular to this kind of Moth. 


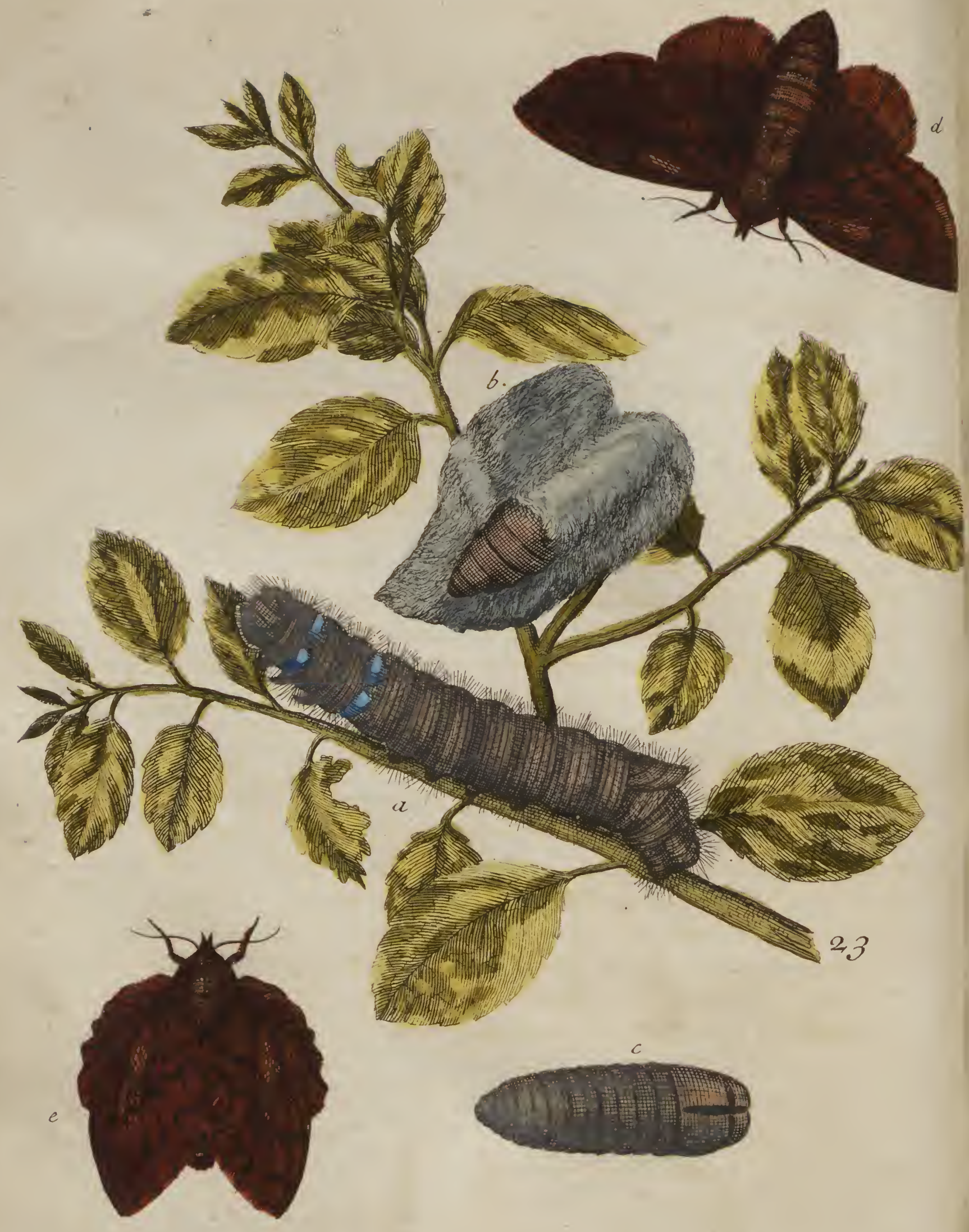

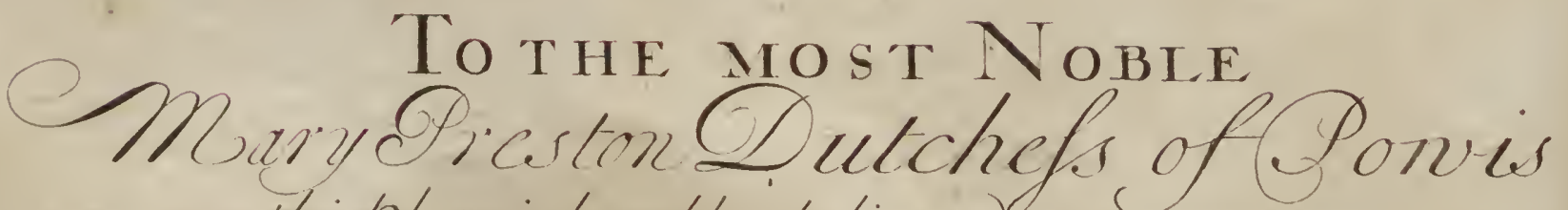
this plate is humbly dedicaud by fleazar. Albin. 


\section{THE}

\section{Defcription of the Sixteenth PLATE.}

The Caterpillar $a$ is of a dark Purple Colour with a mixture of Red and Brown, it hath 4 Blue Spots on its Back near the Head, it had Flaps or Lappets on every Foint, which makes him appear to have fo many Feet. It was taken on the Alaternus about the middle of May; it alfo feeds on the Lauruftinus, Black Thorn, White Thorn, and Bramble. On the 28 th of May. it fpun it felf up in the Leaves in a Greyinh Silkey $W e b$ as: $b$ expreffes, and Changed into a Chrysalis $c$ almoit of the Colour of the CATERPILLAR, and on the zift of Fuly came forth the Moth $d$ of a reddifh Colour with three Ingrailed lines of Black acrols the Upper Wings, and two: of the fame in the Under Wings; the under fide of the Moth is of the fame Colours: the Eggs are White and Atreaked with dark Green: the young CATERPILLARs. live all the Winter. I have fed them on the Bramble till the latter end of April, and then given them. White Thorn and Black Thorn to feed on, and brought them up till their Change. The Moth in its fitting Pofture is reprefented at $e$, which is particular to this kind of Moth. 


\section{T H E}

\section{Defcription of the Seventeenth Pl ate.}

7 HE Caterpillar $a$ is of a light Brown Colour, fpotted with Black and Orange, the Head of a Pale Buff, it had a broad ftripe of White between each Joint on the fides. It was found at the beginning of May feeding on Grafs, and at the latter End of the fame Month it fpun it felf up in a $W e b$ expreffed at $b$ like Whitedbrown Paper, on the Stalks of the Grafs, and changed into a Cbryfalis c, about the latter End of fune came forth the Moth, the Male reprefented at $d$ is of a Brownifh Colour with two White Spots, and a line of a deeper Colour from the tip to the middle of the Infide of the $U_{p p e r} W$ ings, the Horns are large and Feather'd, as are thofe of the Males of many other Species; the Female $f$ is of a Yellowith Buff, with the fame marks in the Wings as the former. I open'd one of thefe CATERPILLARs which died without Spinning or changing, and found it had been Flyblown, for in it were Six large Chryjalides, expreft at $b$, from each of which came forth a Fly, as in the Plate at $i$. Two of the Motbs within a few Days after their Change coupled, and the $\mathrm{Fe}$ male laid Eggs of a flattilh round form, and Whitifh Colour, with a circle and fpot of Green on each. They hatched towards the latter end of $\mathcal{F u l y}_{\text {, }}$ and the CATERPILLARS lived all Winter. I have found them in the Fields in October and November, under Hedges and Thelter'd places, about the bottom of the Stalks of Grass. This CATERPILLAR is the fame with that in Lifter's Godart, n. 82, who faith, it is a thirfly Animal, and drinks by dipping its Head in the Water, and then lifting it up as Hens do, which it repeats over and over again, for whichreafon it bears the Name of the Drinker. See alfo Ray Hijt. Infect. $p .142 . n .3$.

$N$. B. I have never obferved this, though I have brought up many. 


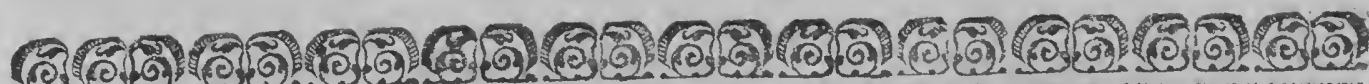 m

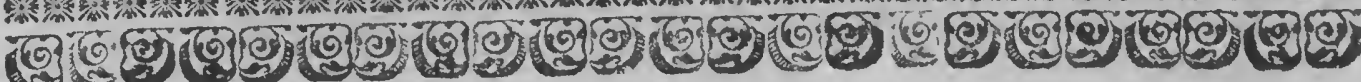

\section{T H E}

\section{Defcription of the Eighteenth PL AT E.}

THE Caterpillar $a$ is fpotted on the Sides with White, the Openings between the Foints of the Back are like Black Velvet; the other parts of its Body Brown. It was taken on the $W$ bite Thorn at the beginning of May; and about the roth of Fune, it fpun it felf, in the Leaves, a britle brown Cafe b, in form of an $E g g$, like C A T E R P I L$\mathrm{IAR} a$ in the next Plate; (for which reafon they are called by fome the great and fmall Egger,) in the aforefaid Case it changed into a Chrysalis as is expreft at $c$, and at the latter end of fune came forth the Moth; the Body and Wings of the Male $d$ are of a Brown Colour towards the Shoulders, the lower part of both Wings are of a lighter Brown with a ftripe of Yellow in the middle, between the Shades, and a fpot of White in each Upper Wing; the Female $f$ is of a pale Tawny with the fame degrees of Shades, and the like fpots as the Male. Thefe Moths coupled, and laid Eggs of an Oval form, and fpotted like thofe of a Turkey. They hatched at the latter end of $F_{u l y}$, and lived with me all the Winter. I fed them firft on White Thorn and Black Thorn, when thefe failed on Bramble, the Leaves of which are to be found all Winter; and in the Spring following I gave them their Liberty, knowing their Change. See Godart p. I Tab. 7. Lifter's Godart n. 88. Marian Vol. 1. Chap 10. Moufet p. 92. n.9. Ray's Hift. Infect. p. I 42. n. 2. who calls it Pbalana maxima fulva, alarum Exteriorum fuperiore medietate intenfius colorata, cum maculầ in medio alba, inferiore dilutiore. 


\section{T H E}

\section{Defcription of the Nineteenth PL ATE.}

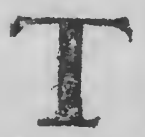

HE CATERPILLAR a is Black, with two rows of Brown Spots encompaffed with Yellow on his Back, the Head is of a Brownifh Afh Colour; the Feet Black, and the Holders Red. It was taken on the 17 th of Fune on the Black Thorn, and the w2th of 7 uly it fpun it felf up in the Leaves, a brown hard brittle Cafe in thape like a Birds Egg, (after the manner of the CATERP I LL AR in the Eighteenth Plate,) and changed into a Chry falis expreffed at $b$, out of which came forth the Motb $c$, the Body and Vpper IVings of a pale reddith Brown, with two White Spots, and a line of the lame acrofs each Upper $W$ ing; the under fide $d$ had the fame marks, but fomething paler. Thefe C A TERPIL L A R $S$ are always found in Colonies, the whole Neft of them feeding together, till they are ready to change; as foon as they are hatched from Eggs they fpin a $W e b$ to thelter themfelves from the Weather, and as they grow enlarge it with feveral Divifions; they feldom go from the Plant they are firft hatched on, till they have eaten it quite bare, and want food; when they go abroad to feed, they ordinarily fpin a Thread from their main W eb to guide them home again; this is very particular, and feems neceffary to them; for I cou'd never feed them up without raking the whole Neft with their Web.

The CATERPILLAR expreffed at $e$ is ftriped with Blue and Orange Colour on his fides, and a White Stripe down the Back refembling a laced Livery, from whence it's commonly call'd the Lacquey, the Head Blue with two Spots in Imitation of Eyes, it has fmall Tufts of Hair on each Foint. It was taken the 3oth of May on the Black Thorn, and the 2oth of Fune it fpun it felf up in a Yellowith Silky Web (from which when torn fell a Yellow Powder like Flower of Brimftone) and changed into a Chryfalis $f$, and the 25 th of 7uly came forth the Moth $g$ of a Tawney Flefh Colour,having a Divifion of one 3 d of the middle of the Upper Wings of a darker Colour. The Motb lays her Eggs in a Spiral Order, round the young Twigs of fuch Trees as are proper food for the Caterpillars which are not very nice, for they eat the Leaves of any Fruit Trees, Whice Thorn, Black Thorn, Bramble, Lawrel, and feveral others; they are Hatched in the Spring, when the young Leaves come forth, and kcep together in a Web while young, fo are eafily deitroysed, if care be taken then. Some of them were Flyblow'd, and produc'd the Maggot expreffed at $k$, which changed into the Chryjalis 2 , from which came the Fly $m$. See Godart. $p$. I. Tab. 10 . 


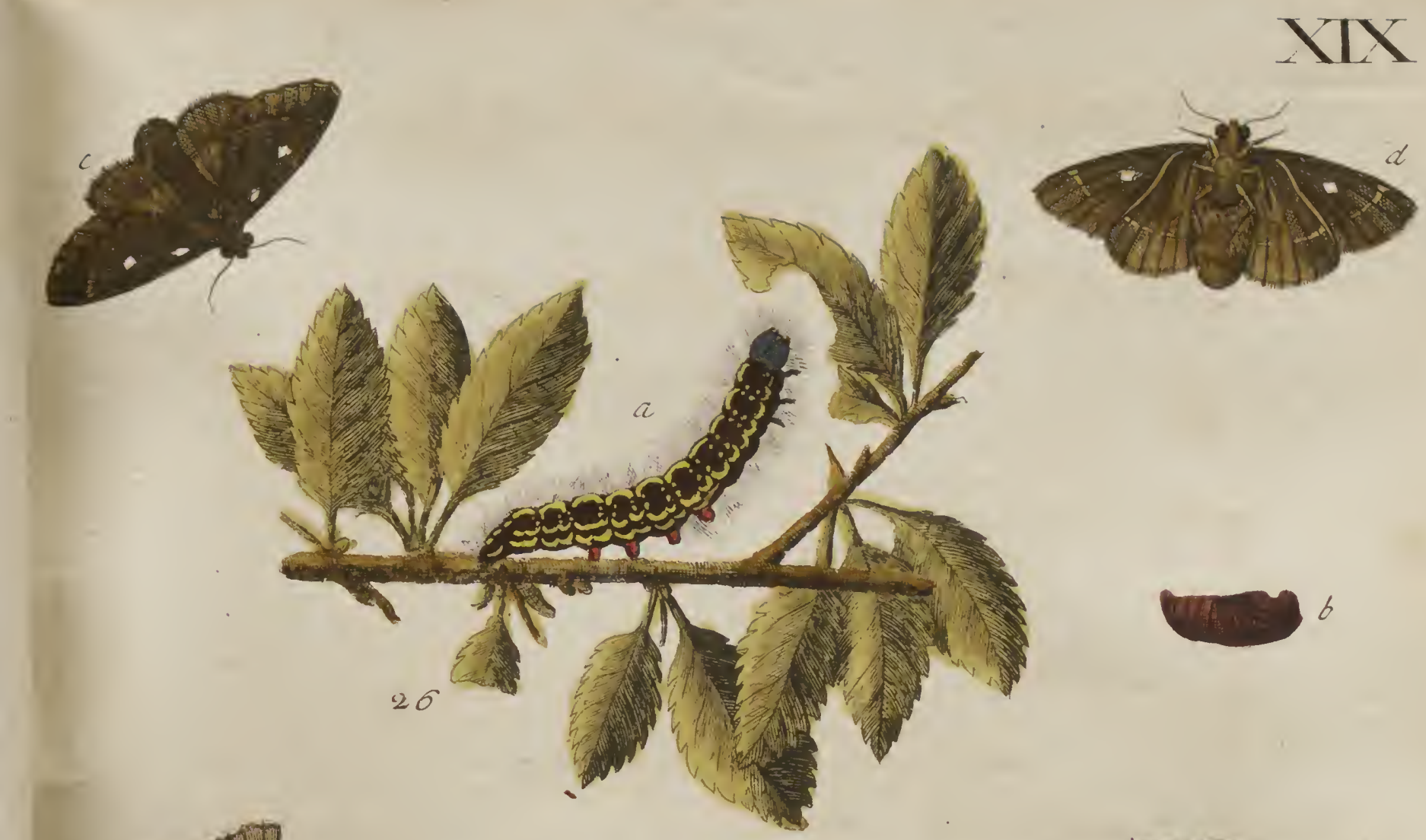

\section{XIX}
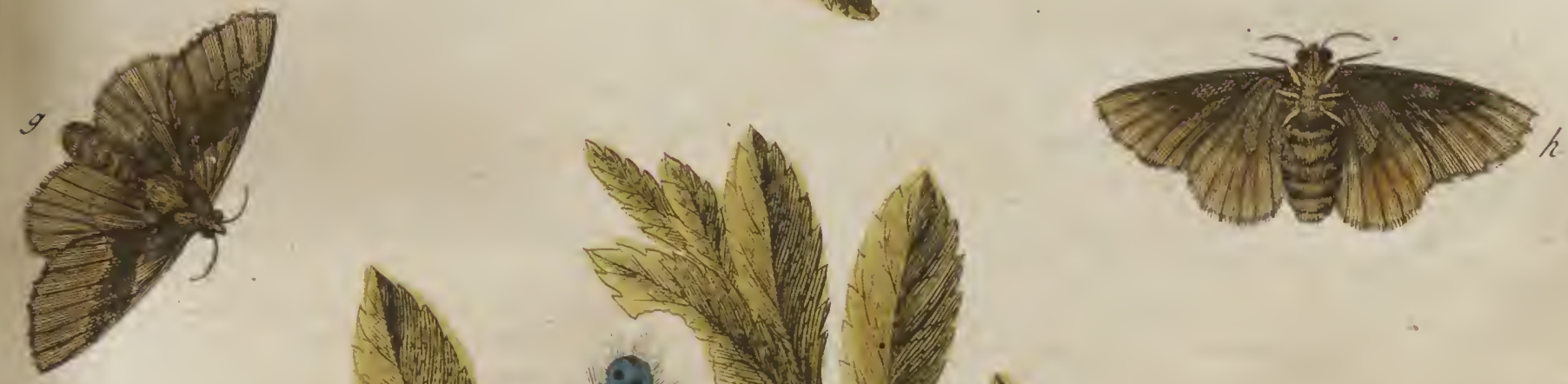

(x)

\section{To the Right Hon o rabie . The Don: ad he Gerraid}

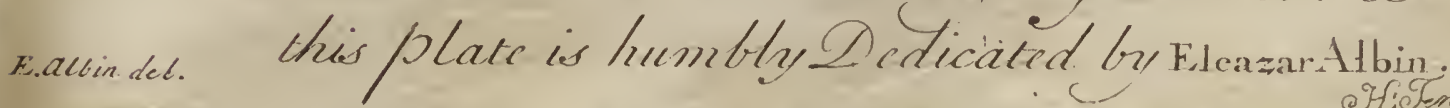



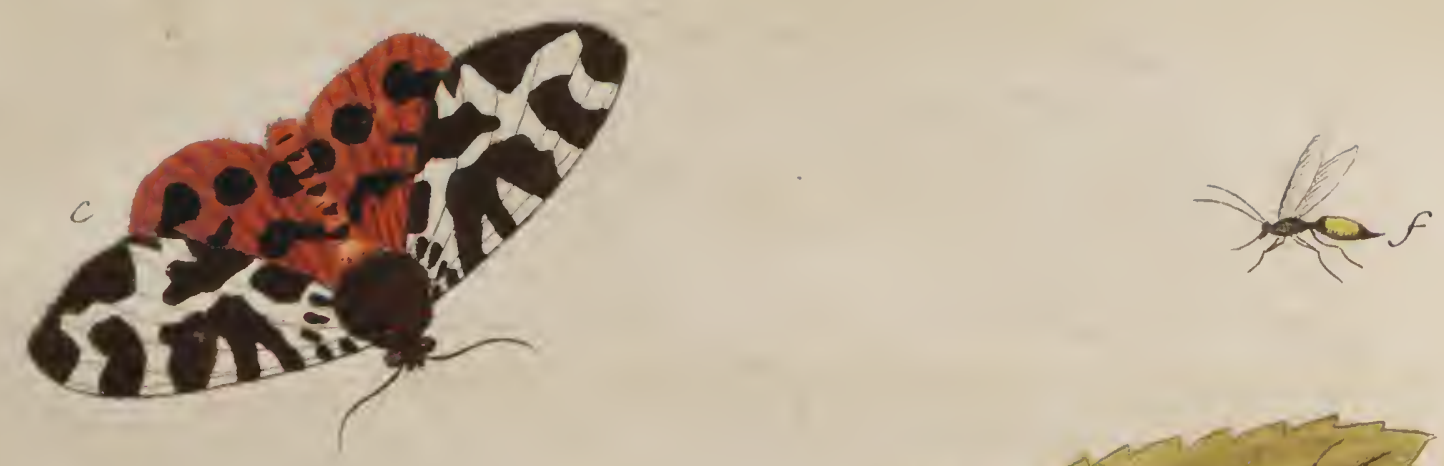

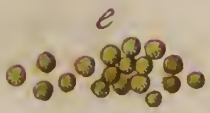
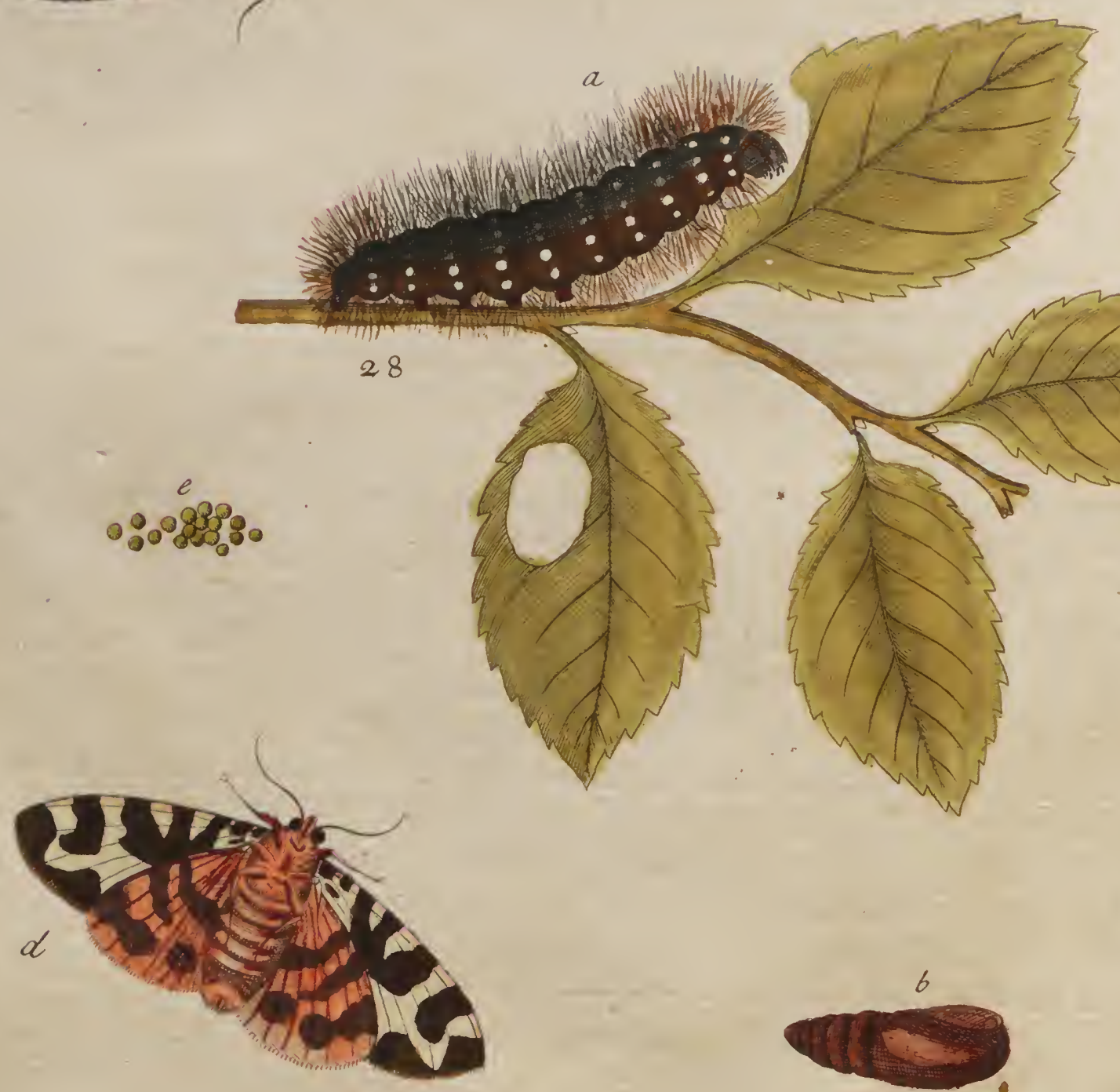

Whillowe
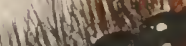

A.

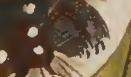

Inith $m$
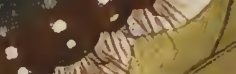

28
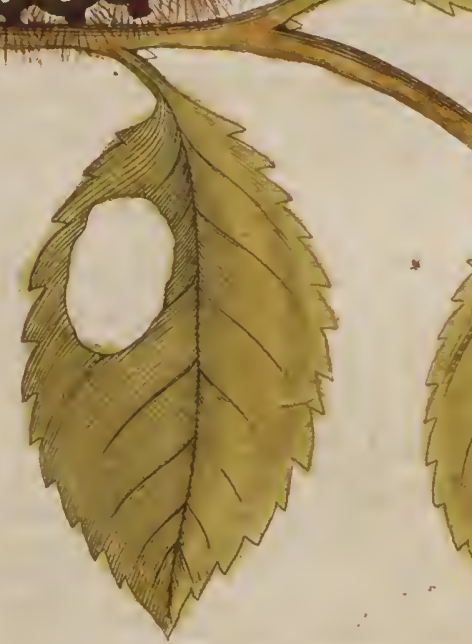


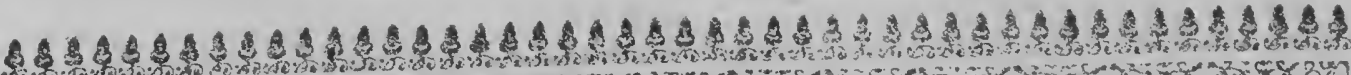

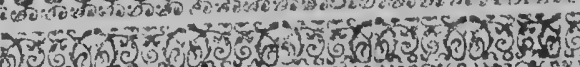

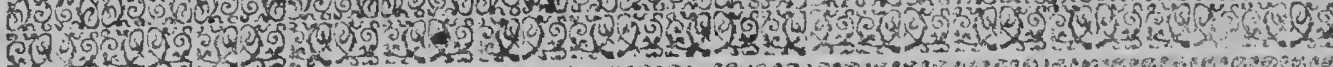

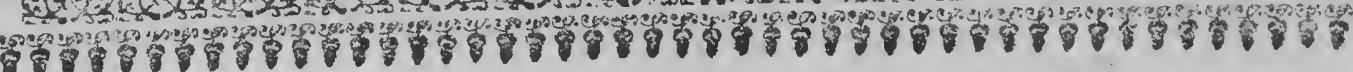

\section{THE}

\section{Defcription of the Twentieth PL A TE.}

THE CAterpillar $a$ is Black, the Hair on the two Foints next the Head and on the Sides Orange Colour, and on the Back Black. It hath a Row of fmall White Spots, refembling Pearl, on each foint. When any thing difturbs it, it rowls it felf up like Hedg-hog, and lieth in that Pofture while apprehenfive of danger; afterwards haftens from that place. It was taken in the beginning of May feeding on the Plum-Tree; they likewife feed on the Currant-Tree, Nettles, Teafel, Lettice, Cbickweed and many other Plants; it fpun it felf up to the fide of the Box in a thin Grayifh $W e b$ the roth of June, and changed into a black Cbryfalis the $x$ th of the fame Month, and the 3 d of Fuly came forth a Beautiful Moth, $c$, the Body and Upper Wings of which are dark Brown, divided by feveral broad Streaks of White; the Belly and Under Wings Red, fpotted with Black, the under fide of the Moth $d$ of the fame Colours, but paler: Theyoung $C_{A T E R P I L L A R S}$ are hatched in Autumn, and live all Winter. I took fome of them which were Flyblow'd, the Maggots eating their way out of their Sides, fpun themfelves Cafes of Yellow Silk, and produced the Icbneumon expreffed at $f$.. See Lifter's Godart n. 99. Moufet I . p. 93. and the CATERPILLAR his $2 \mathrm{~d} p$. I86. See alfo Ray's Hifl. Infects p. Is I. n. 3. and p. 152.ñ. 7. alfo Marian, Vol. 1. ch.5. 


\section{T H E}

Description of the Twenty Firg PrATE.

HE MOTH whole Upper fide is reprefented at $c$, and Under fide at $d$, was brought me in June. It laid Eggs like fmall Pearls, which towards the latter end of the fame Month produced Hairy blackifh CATER PILLARs, with fmall Brown Spots on each Foint, their Heads, Feet and Holders Crimfon. I fed them upon Bramble, Black-thorn, Bur. dock, Nettles, and Cbickweed; they liv'd thorough the Winter, and about the beginning of May fpun themfelves up in a thin Web, and chang'd into a Chryfalis $b$, and on the 20 th of May came forth the Moth, whofe Upper Wings and Body were Black, with large Cream Colour Spots, the Under Wings are Orange Colour fpotted with Black; the under fide of both were of the fame Colours. The Belly Black edg'd with Scarlet. See Marian Vol. x. Ch. 6.

The CATERPILLAR $e$ is of a dark Brown Colour with Black Spots, and a fmall Yellow Spot on each Foint, the Head and Feet Black, the Holders edg'd with Red. It was taken the 8th of Auguft feeding on Water-Mint; it alfo feeds on the Dutch Willow, White Ladies Bed Straw, and feveral other Plants that grow near the $W$ ater. The i 2 th of the fame Month, one of them went into the Ground and chang'd into a very Black Cbry falis with fmall Black Spots on the Jides, and the $23 \mathrm{~d}$ of May following came a White Moth with fmall Black Spots on its Wings, the upper part of the Belly Orange Colour fpotted with Black. I was furpriz'd to fee a CATERPILLAR and Chryfalis both fo Black produce a Moth fo very White. 

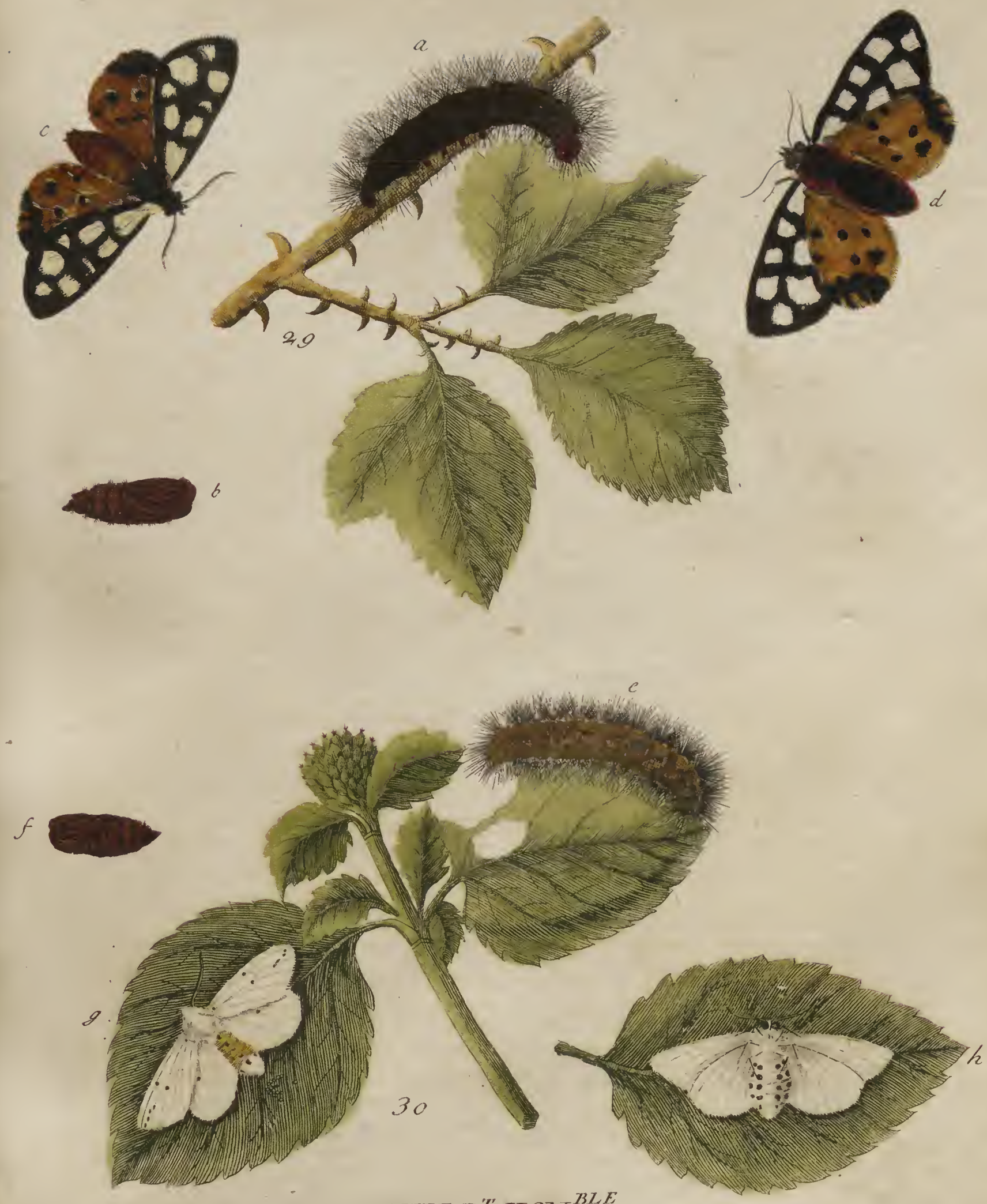

TO THE R HON!

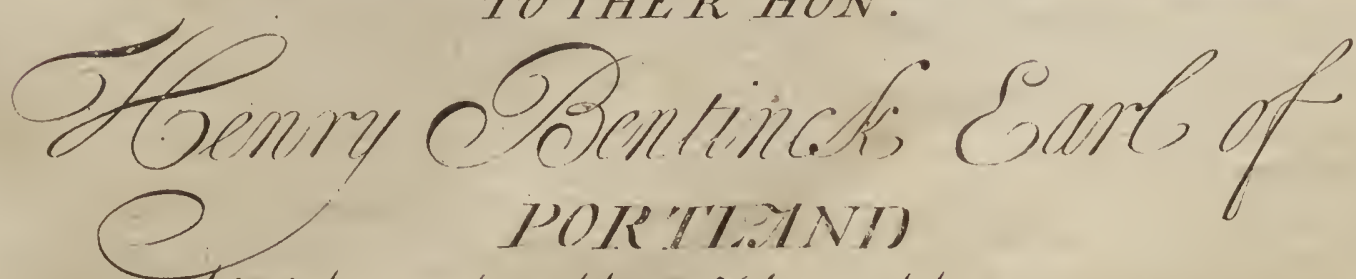

this plate is humbly ODedicared by vicasar Albin.

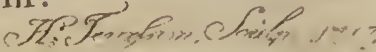




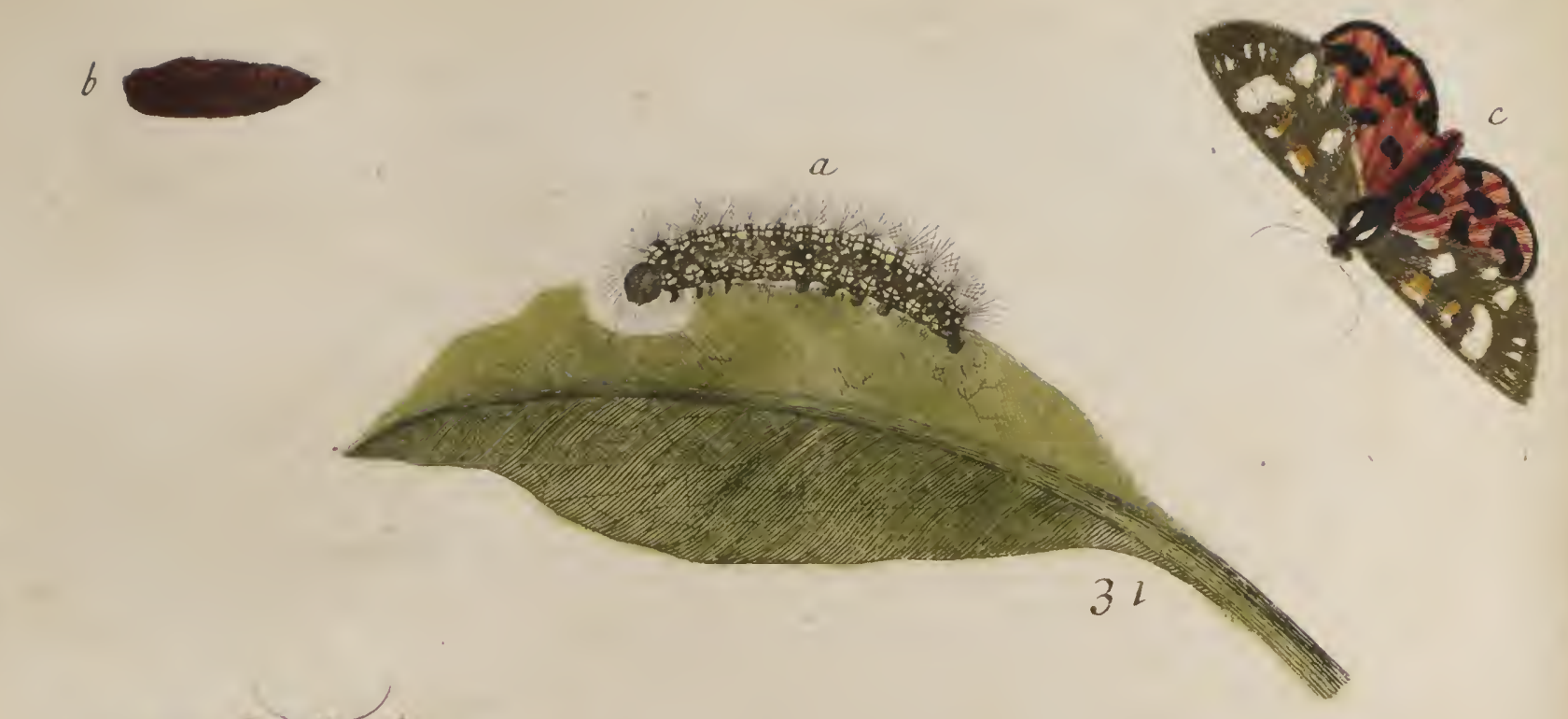

$d$
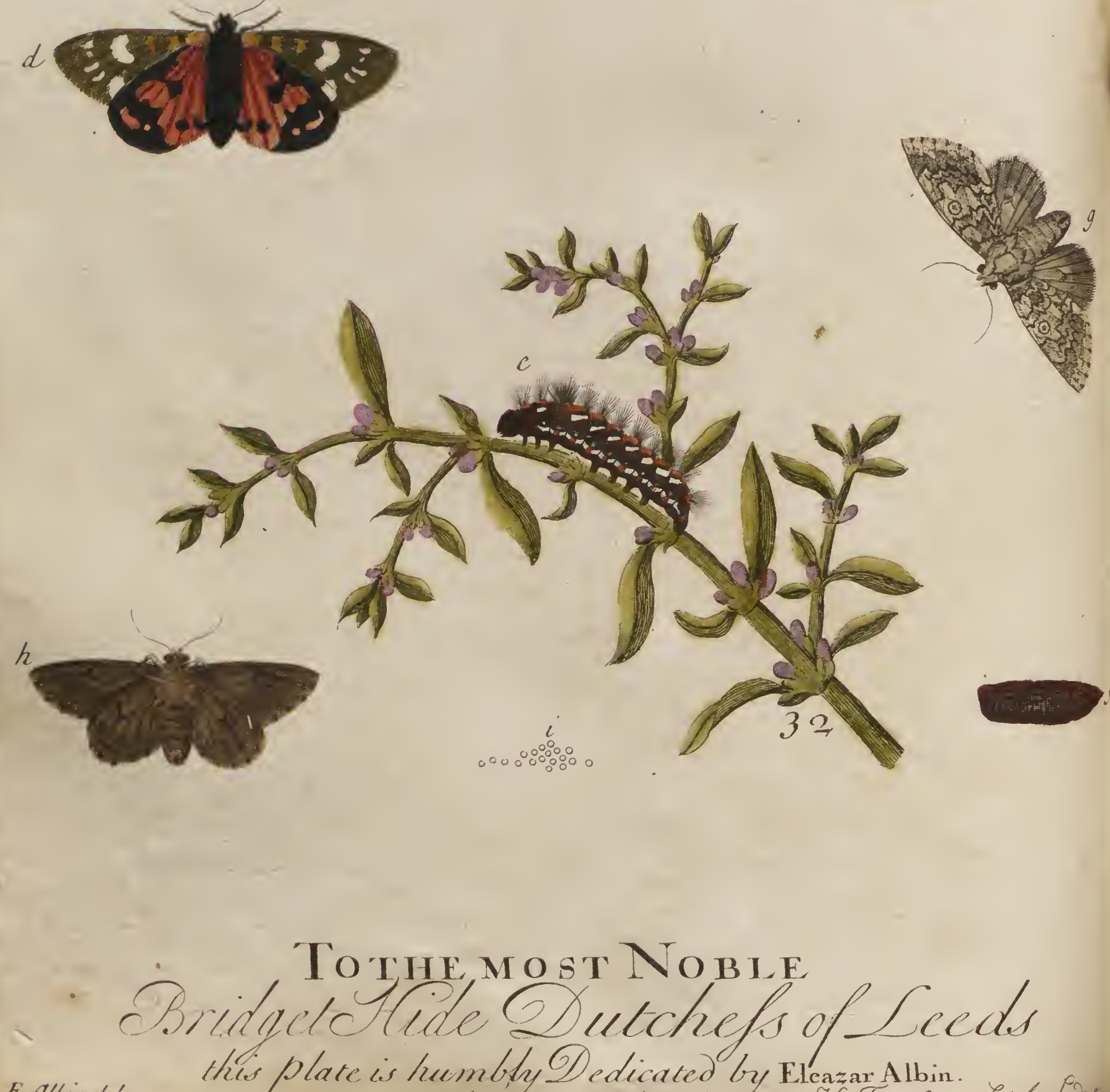


\section{TH E}

\section{Description of the Twenty Second Prate.}

HE CATERPLLAR $a$ is mark'd with indented Streaks of Black and Yellow, with Rings and Spots of the fame Colour on each Foint, the Head and Feet of a deep Black, the Holders of a brownifh Red. It was taken the I th of April feeding on Hounds-Tongue; and the 7 th of May it went into the Ground and chang'd into a Chrysalis; and the $3 \mathrm{~d}$ of June came forth a very beautiful Moth, the Back and Upper Wings $c$ of a dark thining Green fpotted with White and Yellow, the upper part of the Belly red with a Black Stripe down the middle, the Under Wings red fpotted with Black, the under fide d, the Breafts and Belly Black, the Wings of the fame Colour with the upper fide. Thefe CATERPILLARs being at full growth fo early in the Year, makes me believe they live all the Winter, as feveral others do.' See Marian, Vol. 2. ch.8.

The CATERPILlar $e$, is of a Brown Colour, with a Yellow indented Stripe on each fide, and a Spot of Red, with a fmall Speck of White on it, on each Joint; the Back is very elegantly mark'd with oblong Spots of White and Red, the Head, Feet and Holders are of a Pale Reddinh Brown. They were taken the 24.th of Auguf on the Knot Grafs; they likewife feed on the Bramble. Some of them fpun up againtt the fide of the Box the 29th of Auguft, mixing their Hair in the $W e b$, and the r 2th of May following came forth the Moth; the Back and Upper Wings of a light Hair Colour with Shades and Lines of Black, the Under Wings and under fide of the whole Moth are of a Paler Colour. 


\section{T H E}

\section{DESCRIPTION of the Twenty Third Plate.}

THE Caterpillar $a$ is Yellow and Black fo mix'd as in a manner to refemble Scotch Plad; the Head, Feet and Holders are Black, with a Spot of the fame on each Foint. They were taken the 20 th of Auguf on the Oak. I have alfo found them feeding on Lime Tree, Sallow, Willow, and in great Numbers on the Ofiers in the Aits near Brentford, (where I thot a young Cuckow, and opening him found his Crop full of them,) fome of them went into the Ground the 4 th of September, and chang'd into a Chryfalis exprefs'd at $b$. The 3 oth of May following came forth a beautiful Moth, the Upper Wings $c$, of a bright Afh Colour, thadow'd and powder'd with light Brown, with double ingrail'd Lines of Red and Black acrofs: them, the Back and tip of the Upper Wings have a large Spot of Buff on each of them; the under fide of the Moth is of a Pale Buff inclining to White. See Lifter's Godart n. 95. Ray's. Hift. Infects $p .162 . n .14$.

The CATERPILLAR $e$ is of a dark Brown, with ftripes of Yellow from Head to Tail, the Head, Feet and Holders are Brown. They are found on the Oak, Hafel, and LimeTree towards the latter end of May. One of thefe I fed went into the Ground about the 2oth of $¥$ une, and chang'd into a Chryfalis as $f$ expreffes, and the roth of February following came forth the Moth $g$, of a Pale redifh Brown; one of thefe Caterpillars being Flyblow'd produc'd an Ichneumon at $b$, of a dark red Colour, on the 28 th of April. 


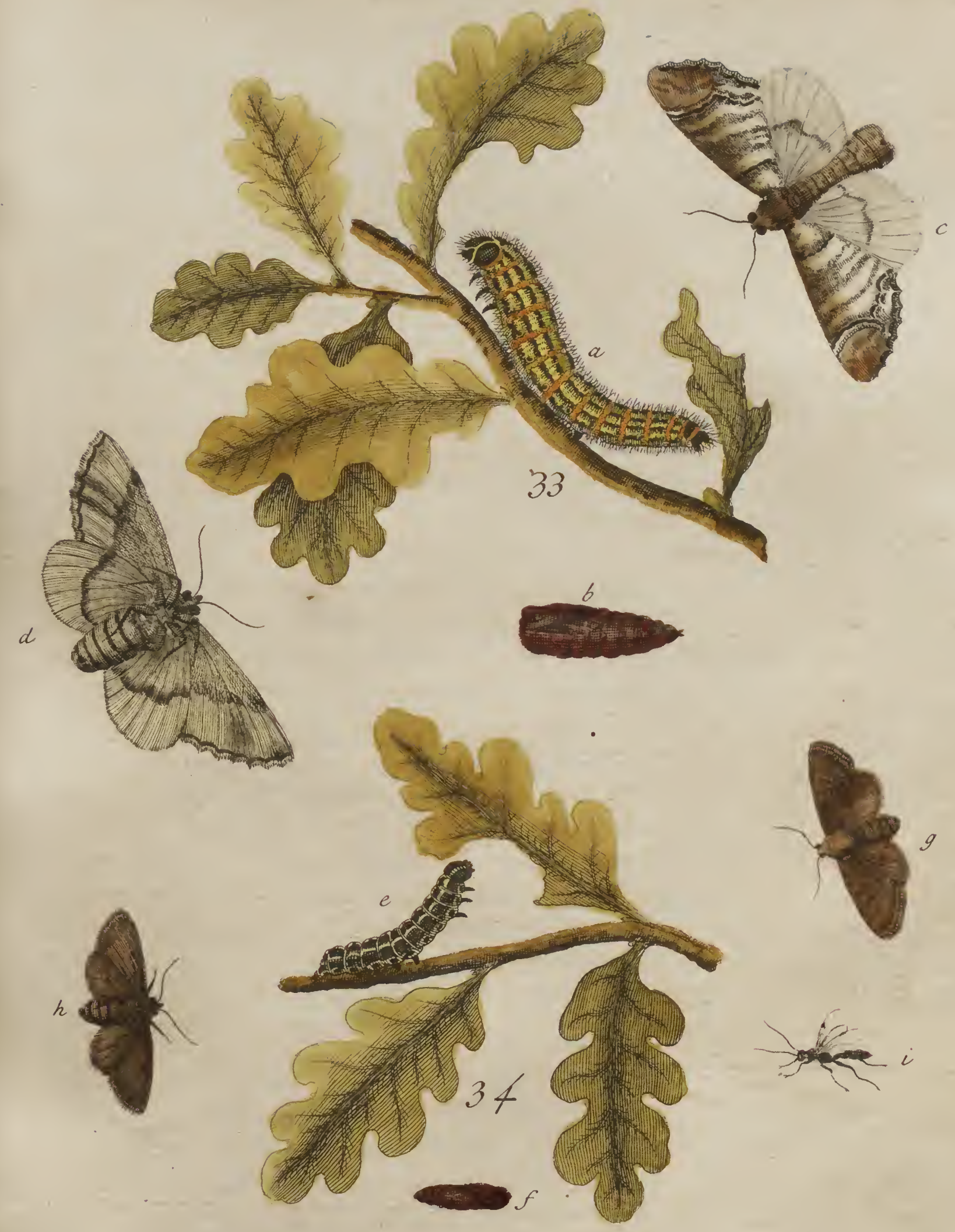




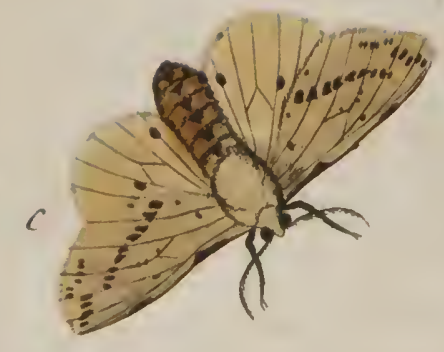

-
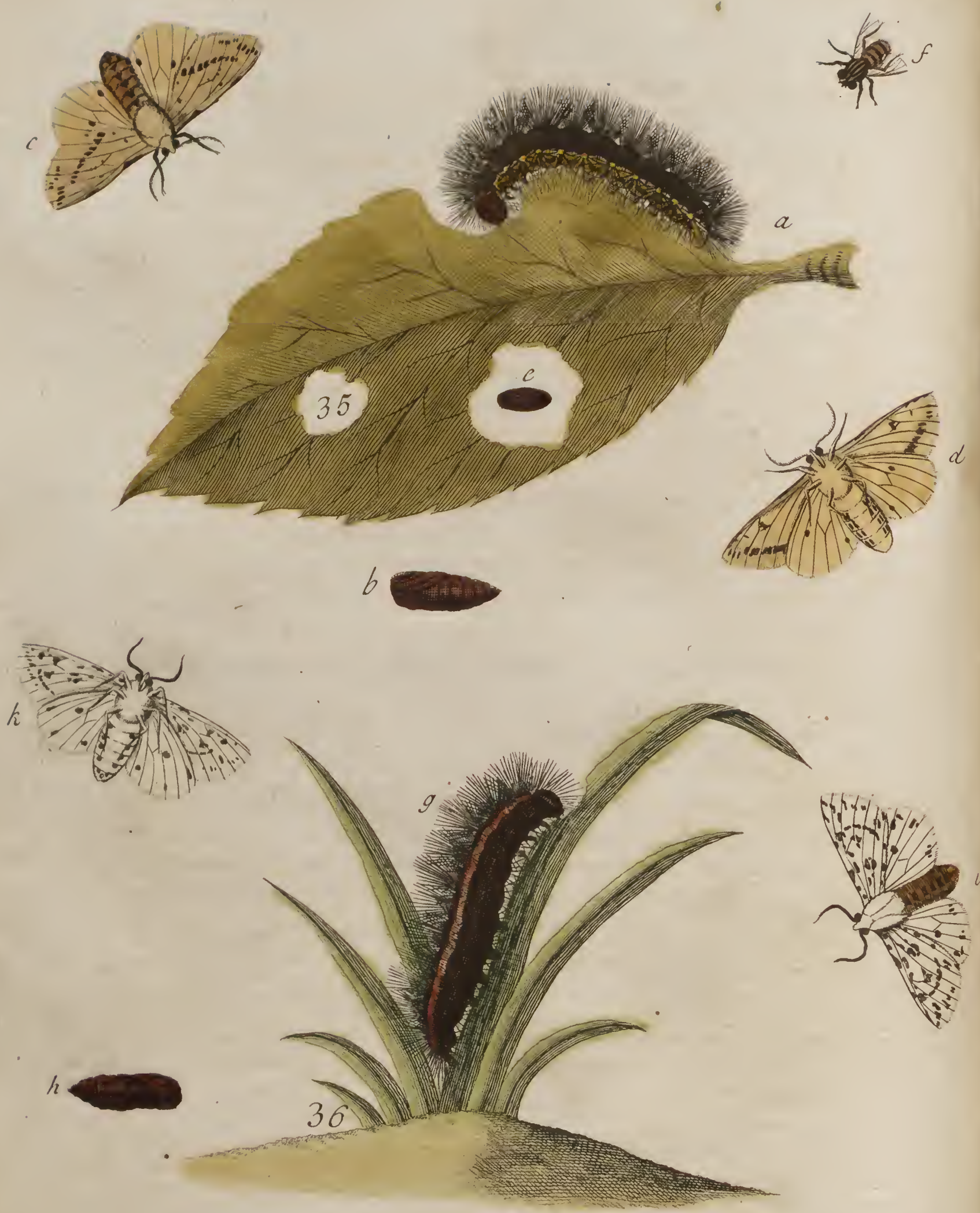

To. Tho: Bee of Harlnell in the County of Bucks Bur.

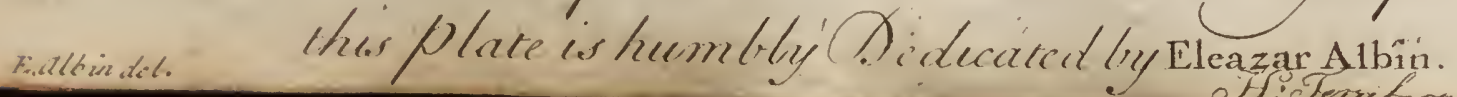

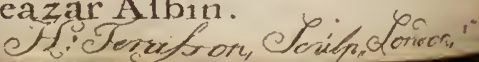


DESCRIPTION of the Twenty Fourtb PLATE.

7 HE CATERPILLAR $a$ is of a Brown Colour on the Back, the Belly is of Yellowifh. Green, parting from the Brown by an Afh Colour Streak fpotted with Yellow, the Head and Feet are of a Brownifh Yellow. It was taken the I 6th of Fuly on the Ferufalem Artichoke, they feed alfo on Elder, Nettles, Lettice, and divers other Plants. They Spun up about the middle of Auguft, and changed into a Cbryfalis b, and the isth of May following came forth the Moth c, of a Buff Colour fpotted with Black; their Eggs are of a light Green. They hatch'd the I 3 th of Fune. The $\mathrm{CA}_{\mathrm{A}}$ TERPILLARS, when firt they came forth of the Eggs, were all White and Hairy, fome of them were Flyblow'd, and each produced one Cbryjalis and $F l y$, reprefented at $e$ and $f$ in the Plate. Thefe CATERPILARs are very common and mifchievous in moft Gardens; but may be eafily thak'd off the Plants and kill'd. This is Godart's 93, in Doctor Lifter's Edition.

The Caterpilla $g$ is of a dark Brown Colour, with a ftripe of Red down the Back, the Head and Feet Black. It was taken in a Garden near Hackney the r 4 th of Auguf ; it fed on Grass, Cbickweed, Orach, Willow, and feveral other Plants. The $2 \mathrm{~d}$ of September it fpun it felf up in the Leaves, and chang'd into a Chryfalis; the 14th of March following came forth the Moth, the Wings on both fides White fpotted with Black, the upper fide of the Tail Orange Colour fpotted. in like manner. This CATERPILLAR is not very common, (this is Godart's 96.) By the Character he gives of the $\mathrm{C}_{\mathrm{A}}$ Terpillar it deferves the Name of the Difembler. See Merian Vol. I Chap. 46. 


\section{Description of the Twenty Fifth PLATE.}

7 HE CATERPILlar $a$ is at the firft hatching Black and Rough, with Stripes of Orange Colour on his Sides, in which ftate he continues 14 Days, and then cafts his Skin and becomes of a Grafs-green Colour with indented Rings of Black fpotted with Yellow; if you vex him, he will eject a clear Liquor out of his Sides, that all his Hair will ftand of a Dew. I am not certain there is any harm in this Liquor, though he feems to emit it in his Defence. The 16 th of fuly one of them fpun up himfelf in a tranfparent Case $c$ with an Entrance much like that of the Baskets which Fifbermen lay to catch Eels, and changed into a Cbryfalis $d$; and on the 18 th of March came forth a Moth, whofe upper Side is reprefented at $e$, and the under Side at $f$; this was a Male: the Defcription of the Female follows.

The Caterpillar $b$ is of a more yellowith Green, fpotted with Yellow as the former, with a narrow Ring or Circle round each Spot. This fpun Her felf up the zoth of Auguft, and the 5 th of April it produced a Female Moth, much larger than the other; they both have an Eye in each Wing, and their other Marks are very much alike, tho' they differ in Colour: The Male being much darker, and his under Wings Orange border'd with Red, and that paler towards the Edge. See Merian, Vol. I Chap 23. 

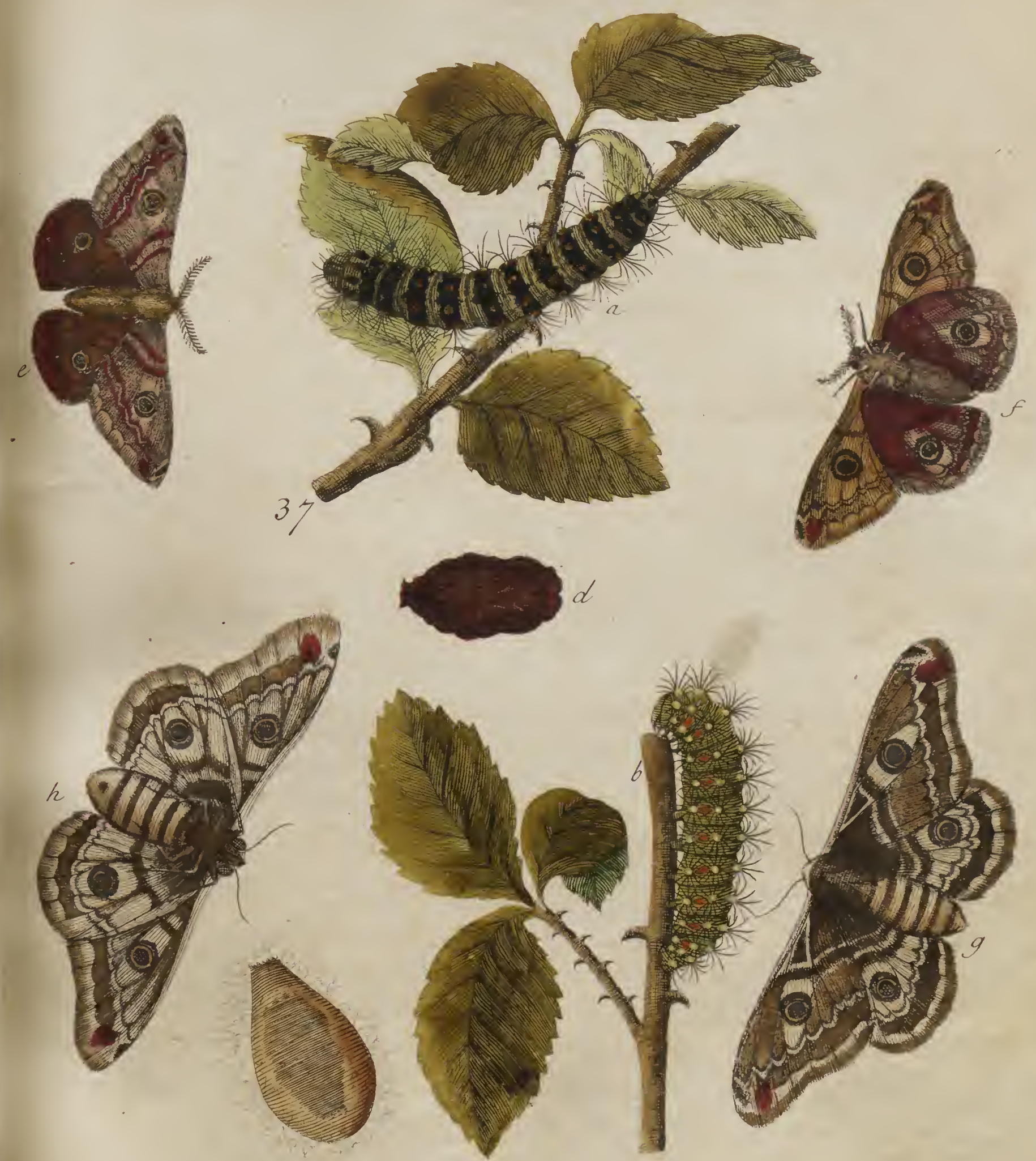

\section{To tue Most Nobl.e}

Gatherive Quechefir of Buckingham 

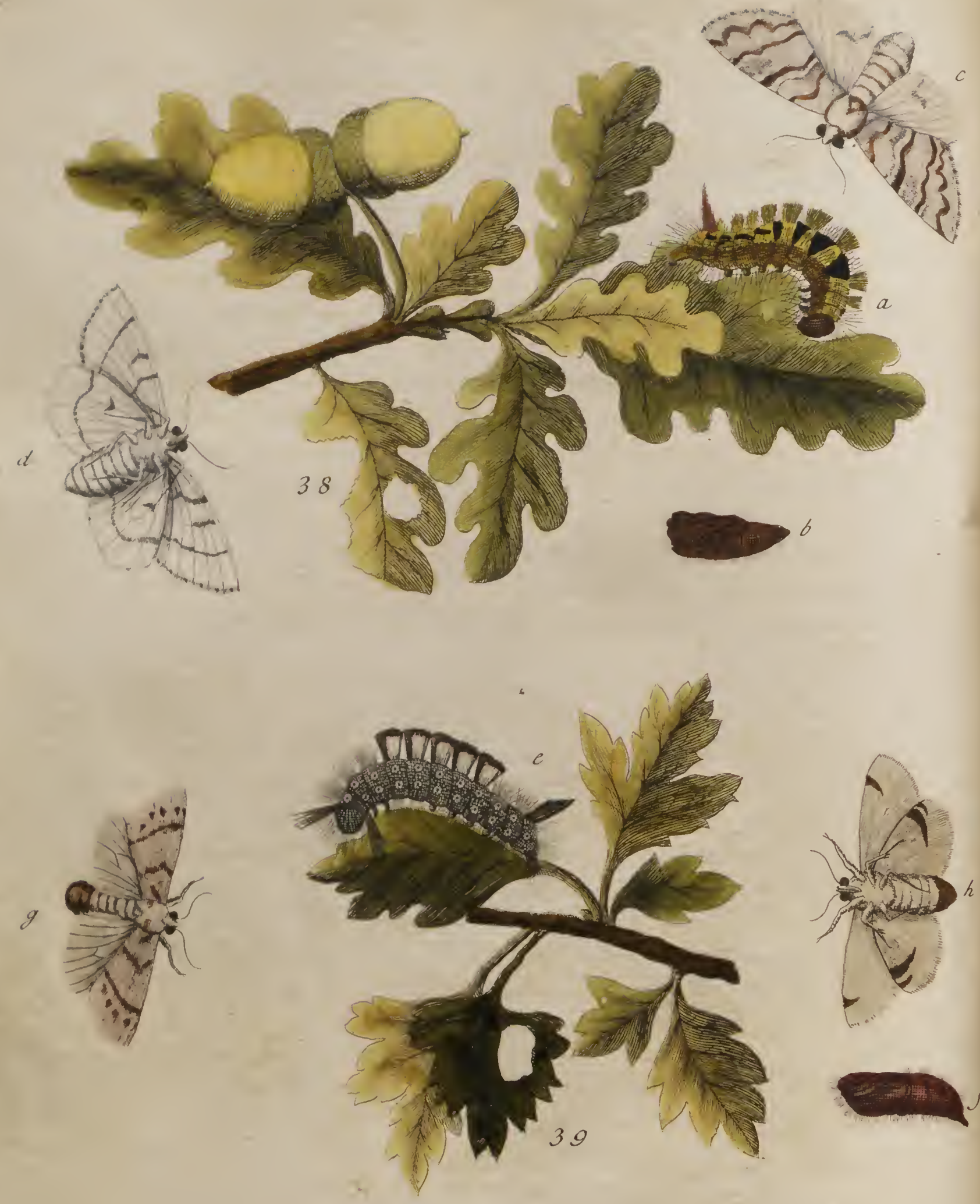

To rift. nost Noble:

Gulci Duke of Grafton 


\section{T H E}

\section{Description of the Twenty Sixth Plate.}

The Caterpillar $a$ in this Table is of a Yellow Colour, fome of the fame Species are of a light Green, others almoft Hair Colour, and fome Reddifh; they have all a Tuft of Hair on each Foint of their Backs, of their refpective Colours; the Openings between the Foints are of a fine Black like Velvet, and each of them has a more longer and more pointed $T_{u f t}$ of Scarlet Hair near the 'Tail. They were taken at the latter End of Auguft on the Hafle, and on the Ioth of September one of them fpun up and changed into a hairy brown Cbryfalis $b$, with Rings of Yellow; and on the 5th of February came forth a white Moth cd Atreaked and motled with Brown. See Merian, Vol 1. Chap. 47.

The CaTERPILLAR $e$ is black, with white Spots on each Foint; on the middle of his Back are 5 white Tufts of Hair, the Tops of which are black; It hath a black Tuft on its Tail, and 2 on its Head reprefenting Horns. They were taken the roth of May on the White Thorn near Pecham and Eltham in Kent, and by the 2 Waters in Hartfordjbire; they alfo fed on Black Thorn and Bramble. Before they fpun up, which was about the middle of May, the Hair of their Sides turn'd Yellow, and the rith of Fune came the Moth $g$ of a light hair Colour, ftreaked crofs the upper Wings, and fpotted with range and pouder'd with Black. Their Eggs were of a light Grey, inclofed with a brown woolly Subftance to preferve them in Winter. This Chryfalis is likewife Hairy and of a dark brown Colour reprefented at $f$. 


\section{TH E}

\section{Description of the Twenty SeventhP L a te.}

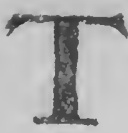

HE 2 CATERILLARS $a a$ in this Table are one of them of a yellowih Green, with pale yellow Spots, and in each of them a fmall black Speck, its Head of a brownith Colour; the other is of a light Brown fpotted as aforefaid, and has a yellow ftripe on each Side. They were taken the 1 th of fuly on the Amara Dulcis, or woody NightJbade, on which they fed till the i 4th of Auguft, and then went into the Ground, and changed into a dark red Chryjalis; and the I 5 th of May following produced a reddifh brown Moth expreffed at $c d$. Some of thefe Caterpillars had each a large white flat Maggot came from them, which made themfelves hard black Cafes lined with 4 diftinct Membranes one within another, from which came an Icbneumon the I ith of May, the Body and Legs of it were of a dark red Colour; from others came 3 or 4 Maggots which changed into fmall red Chrifalies at $e$, each of which produced a Fly about the middle of April expreffed at $f$.

The Caterpillar $b$ was Green friped with White. It was taken in a Garden near Hackney the I 4 th of Fune feeding on the Lark-Spur, it went into the Earth the I 7 th of the fame Month and changed into a Cbryfalis; and the $23 \mathrm{~d}$ of $\mathcal{G}$ ly came a Moth of a dark earthy Colour with 2 black Spots in each upper Wing, the under Wings of a pale Ruffet, as was alfo the whole under Side of the Motb. 


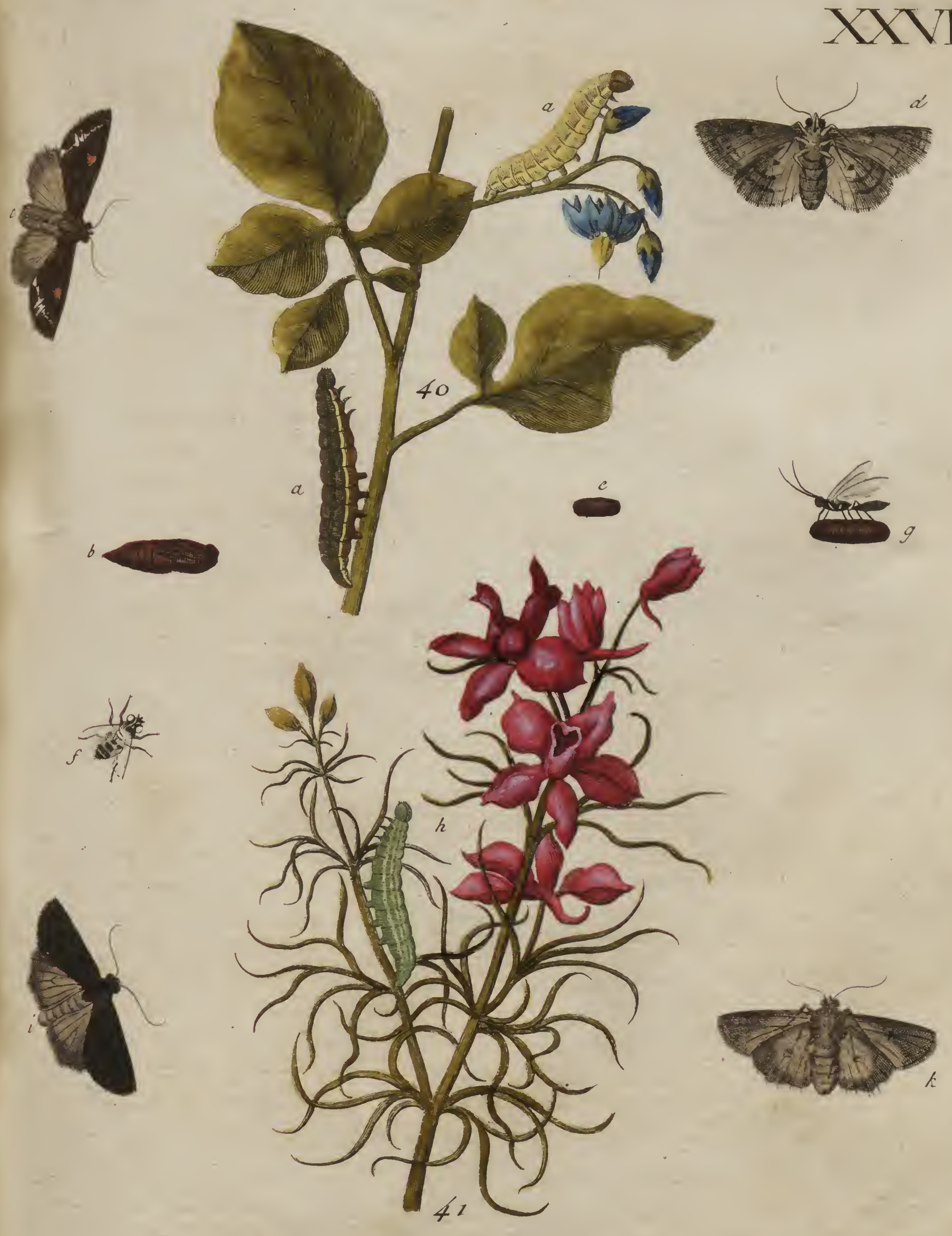

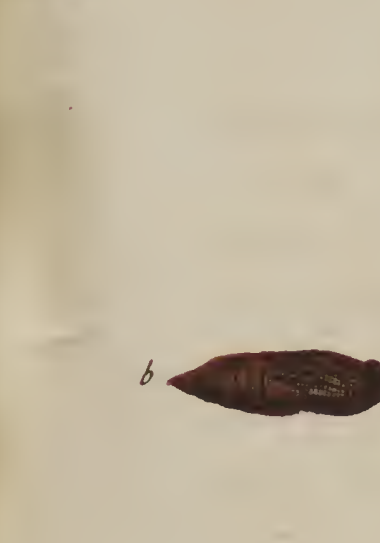

To the Right Ho vorable

- Tenory Eart of Thomond

this plate is humbly Jedicated by Eleazar Albin. 


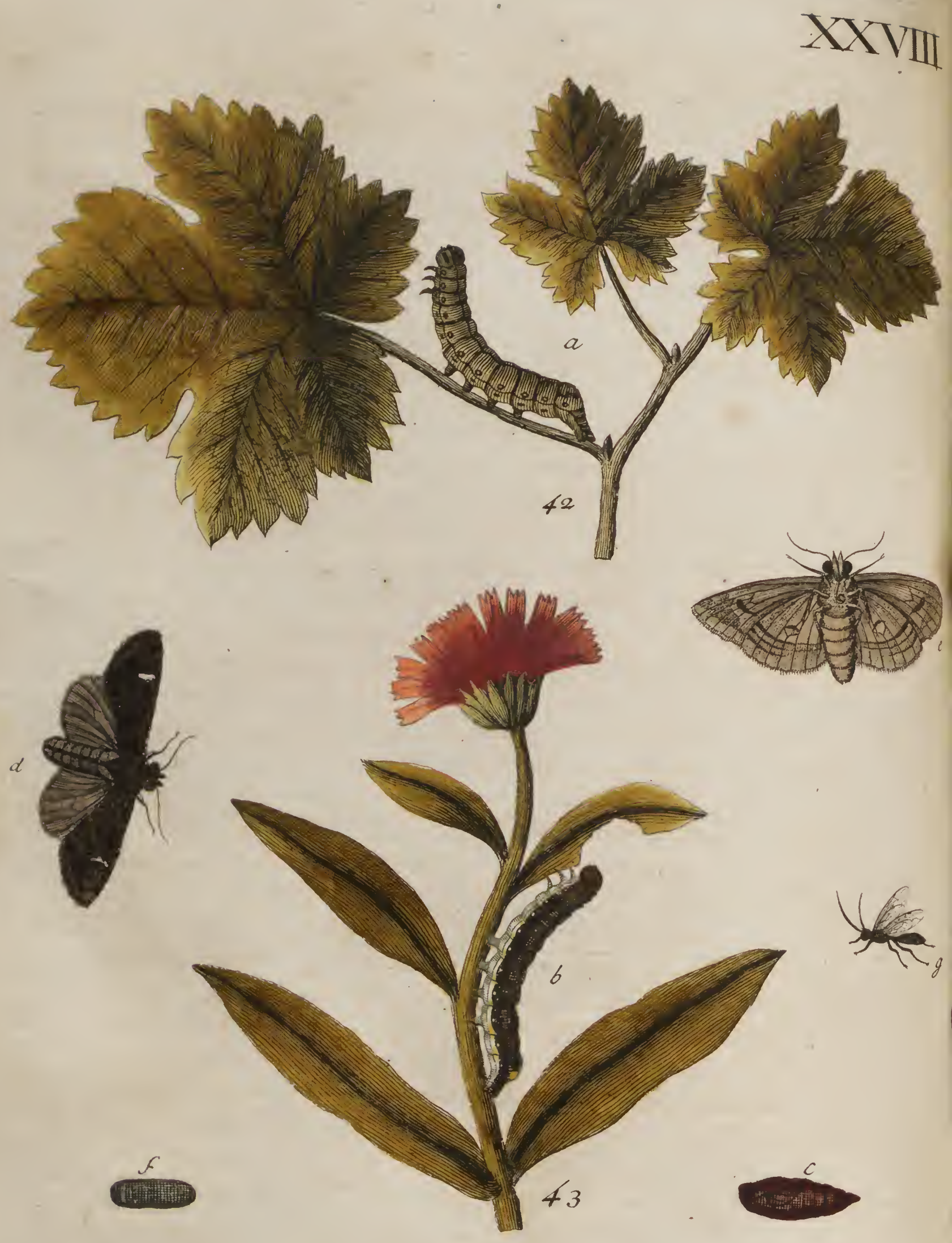

To тhe Right Hoxorable

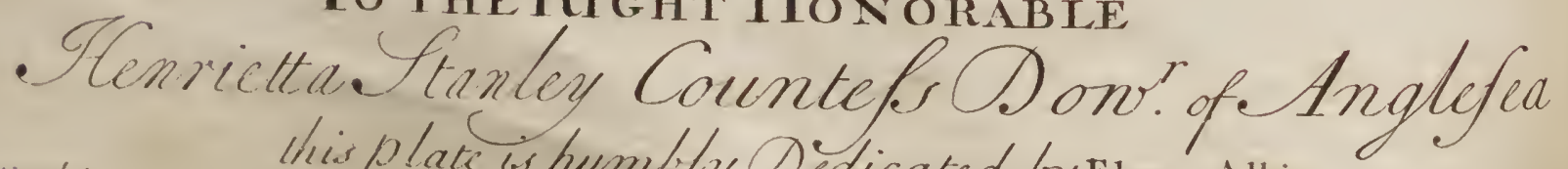
Et alsin dele this plate is humbly Didicated by EleazarAlbin Afi- Feratron, Criphiofirom. 


\section{T H E}

\section{Description of the Twenty Eighth P Late.}

The Caterpillar $a$ in this Table is of an O. 1 live Colour, with a white Spot circled with black, on each Foint. It was taken feeding on the Vine the I 2 th of September, and the 20 th of the fame Month it went into the Ground and changed into a Chryfalis; and the 24th of May came a dark marbled Moth, with 2 Spots of White on the upper Side of each outer Wing, the under Wings and under Side of the Motb were of a Thining Hair Colour. One of thefe CA TER P I L A R S produced an Icbneumon of the fame Kind, expreft as in Table 27.

The Caterpillar $b$ is of a dark Colour on the Back Atriped with Black, the Beily light Green, parted from the dark Colour by a Streak of White, the Head of a deep Yellow. It was taken the 2 ift of 7 uly feeding on the $M a^{a}$ rygcld; they alfo feed on the Horfe-radish, Affricans, and Cabbage, of which laft they make great Deftruction. They went into the Ground the 9th of Auguft, and the Moth came forth in the Beginning of May, which was the fame with the laft defcribed, tho' the CATERPILiars differ in Colour. I am told that by fprinkling your Cabbage Plants with a Lye made of Ajhes and a Quantity of Lime, Salt or Soap-boyler's Liees, you may deftroy them and not hurt your Plants. 


\section{T H E}

\section{Description of the Twenty Ninth Plate.}

THE CATFRPIllars $a a$ in this Table, that on the Leaf is of a dark blueifh Green, ftriped on the Sides with White and Rofe Colour, and a black Spot on each foint; the other on Stalk is of a pale yellow Green, fpotted on the Sides with Rofe Colour and Black; the firft of them goes into the Earth, and changes into a Cbryfalis. They were taken in the Beginning of Augit $f$ on the Orrach; their Change was on the I 8 th of the fame Month, and the Moth came the 27 th of fune following, being of a light Brown or Ruffet Colour, as $c d$ reprefents in the Table; thofe that are yellowifh for the moft part are difeafed, and die without changing into Cbryfalies.

The CATERPILLAR $e$ is of a pale Green, with fmall black Circles on its Sides; its Head and Feet of a light brown Colour: I had 8 of them, not one of them differing from the other in Spots, Shape or Colour. They were all taken at the fame time feeding on the Spear-mint the I $3 \mathrm{th}$ of September, and on the 2,7 th of the fame Month they went into the Ground, and changed into Cbrysalies; and the $23 \mathrm{~d}$ of May came the fame Kind of Moth, as in the Table 28; one of them produced an Icbneumon reprefented at $k$, the Cbryjalis of the Icbneumon at $i$. I have alfo found thefe CATERPILLAR: very large feeding on the Knot-grafs about the $23 \mathrm{~d}$ of Fuly. 


\section{XXIX}
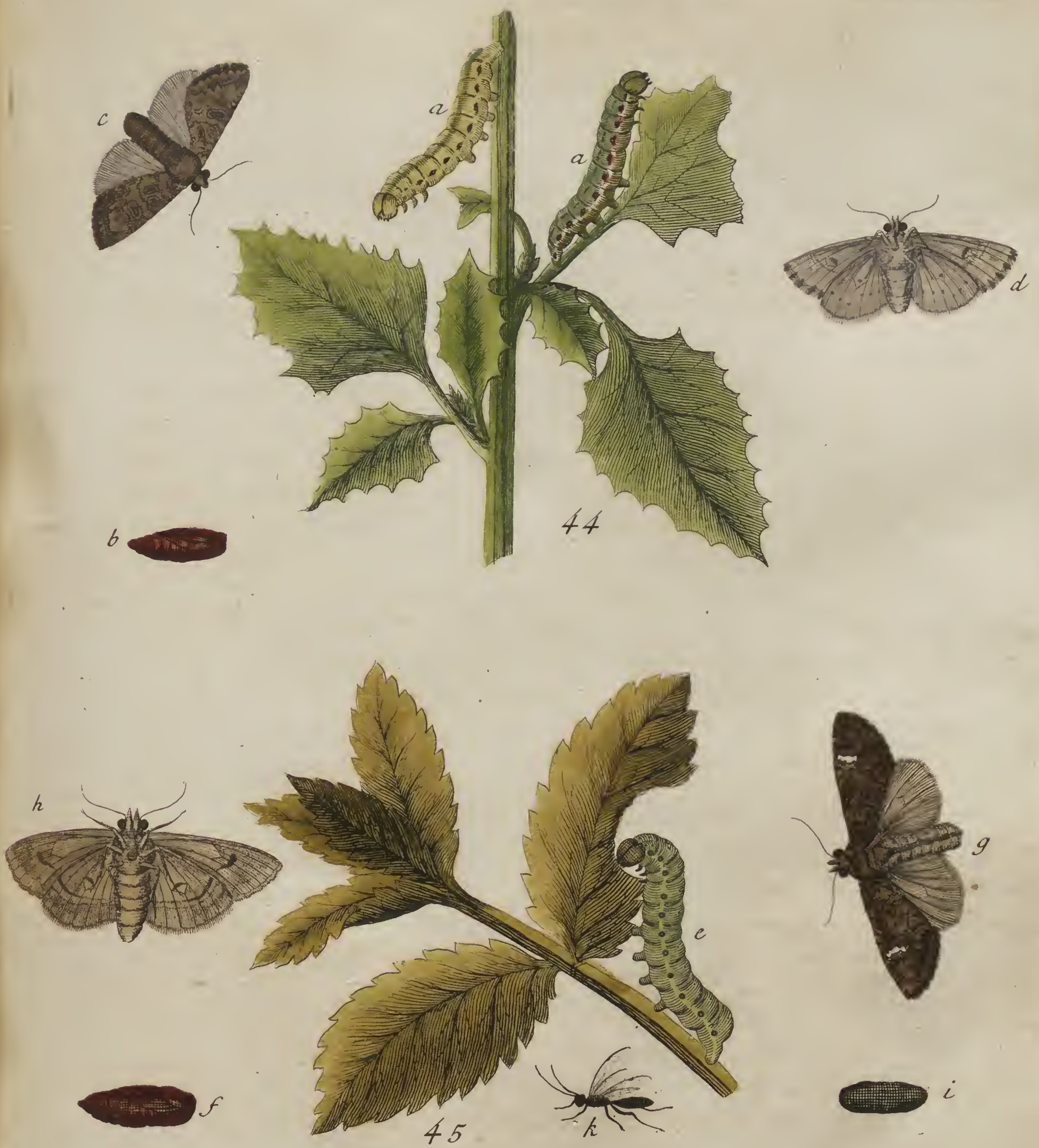

\section{To the Rigit Honorable
Ofn Lord Ashburnham}

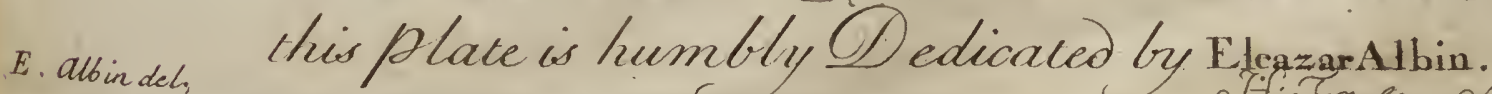




\section{$T H E$}

\section{DESCRIPTION of the Thirtieth PLATE.}

7 HE CATERPILLARS $a$ a in this Table, the uppermoft 1 is of a deep Green, its Head blueifh, the otber of a yellowith Green, the Head of it lighter coloured, they had both a mark of Black on their Backs, on each Foynt like Arrow-beads pointing towards the tail. They were taken on the Bramble the 26 th of Fune near Newington-green, they went into the Ground the roth of $7 u$ ly fpinning the Eartb about them with their $W \mathrm{cb}$, and chang'd into Chryfalies; and on the 6th of Anguft came forth a beautiful fcallop'd winged Moth elegantly marked, as is reprefented in the Table. See Goddart part x. Tab: 56.

The CATERPILlar $c$ is of a brownith Olive Colour; with the fame Marks on his Back as the other. It was raken feeding on Worm-wood about the Beginning of Auguft, and changed into a Cbryjalis on the sth of the fame Month, and on the $4^{\text {th }}$ of September came forth the Moth $d e$. The 3 CATERPILLARs reprefented in this Table, though fo different in Colour, are without doubt of the rame Species as appears by the Motbs they produced; I had one of thefe Moths which did not come forth till the $26 \mathrm{th}$ of November. See Lifler on Goddart, page 54. $N^{\circ}$ al. 


\section{T H E}

\section{Description of the Thirty Firft Plate.}

THE CATERPILlar $a$ is of a pale yellowifh Green, full of fmall Specks with 2 Spots or Points on his Tail. It was found feeding on the Oak in Bi/hop'swood on the 2oth of September; and on the 25 th of the fame Month it worked it felf up a dark brown Cafe on the back-fide of an Oak Leaf, and changed into a Cbryjalis; and the 3 oth of April came the Moth, the Back and upper Wings of a light Green, ftriped as it were with Silver, and edged at the Bottom of the Wings with Crimfon; the Body and under Wings whitifh thaded with yellowifh Green.

The Caterpillar $f$ is of a light blueifh Green, ftriped with White; with fmall black Spots on the lower Stripe, the Head Red. It was found the 3 ift of May feeding on the Elm, it hides it felf by drawing the Leaves together with a Web, and feeds commonly in the Night; it went into the Ground the $3 \mathrm{~d}$ of $\mathrm{F}_{\mathrm{un}}$, and changed into a Cbryfalis $k$; and the 4 th of $\mathcal{F u l y}$ came the Moth of a light brown Colour with darker Shades, the under Wings very Dark edged with Yellow, as $b$ and $i$ reprefents in the Table. 


\section{XXXI}
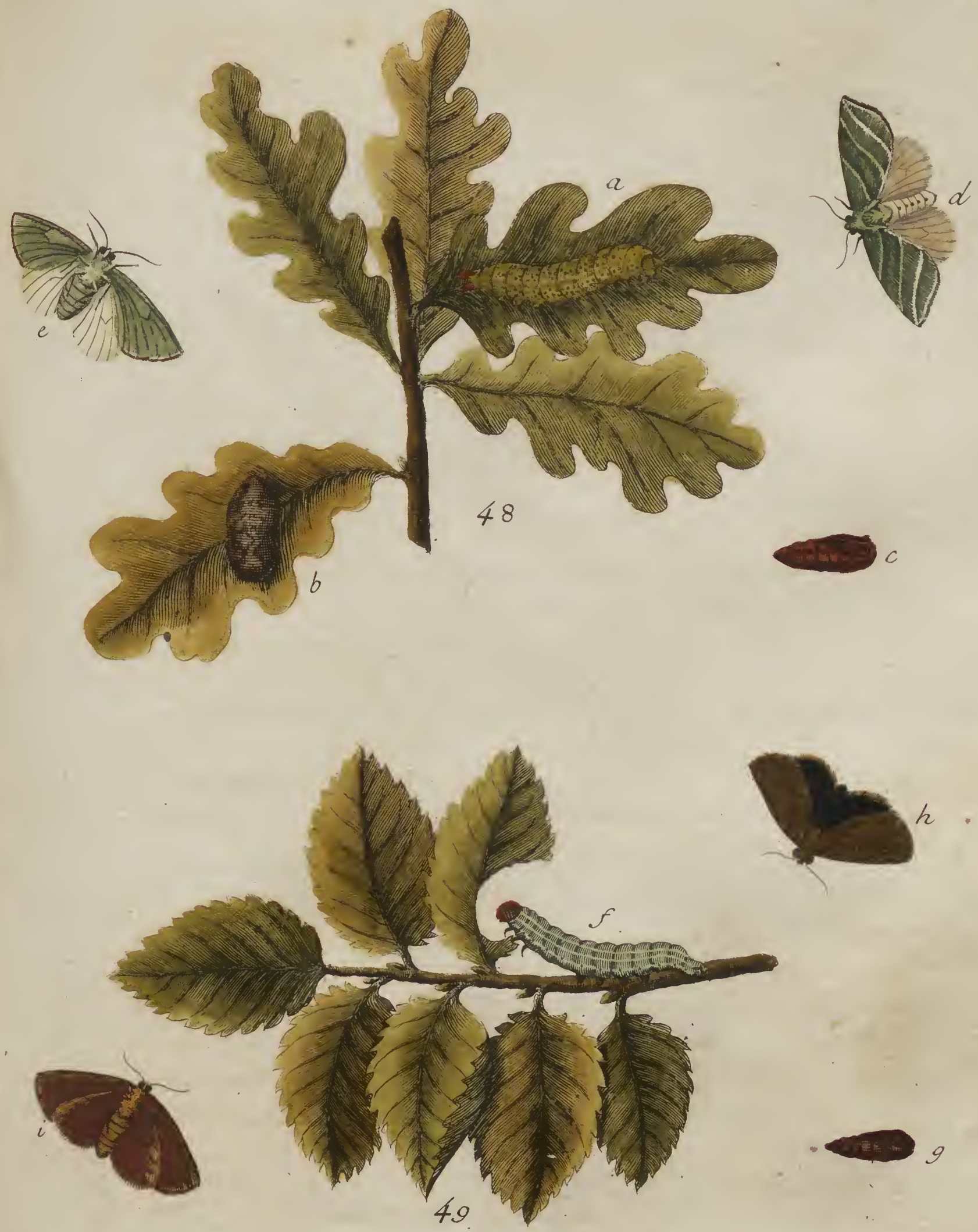

To Renrich Grantham of Sifford in y Cons" of Gfsex Gso'. 
T H E

Description of the Thirty Second Plate.

ThE Caterpillar $a$ in this Table was of a tranparent. Green, with a Line of White on each Side the Back. It was taken on the Sallow near HampAlead on the $24^{\text {th }}$ of $F$ une, on which it fed till the 30 th of the fame Month; at which time it fpun it felf up in a Leaf, and changed into a Cbryfalis; from which on the $2 \mathrm{gth}$ of Fuly came a molt beautiful Scallop-winged Moth, $b$ and $c$ in the Table reprefenting the upper and under Side of it. Sce Lifter on Goddart, page 38. $\mathrm{N}^{\circ} 3^{\circ}$.

The Caterpillar $d$ was of a yellow Colour ftriped with Black, the Head and Holders Red. It was found on the female Fearn, in a Wood by Cbarlton in Kent on the 3 oth. of Augiaf; for want of Fearn I fed it on Orrach, and it grew much bigger than the Caterfillar in the Table, the black Stripe on its Back changing to a reddifh Hair Colour; the $24^{\text {th }}$ of September it went into the Earth, in order to its Change into a Cbrysalis, and remained till the Spring following, then came forth the Motb exprefs'd at $e f$. 


\section{T H E}

\section{Description of the Thirty Third Prate.}

He Caterpillar $a$ in this Table was of an O1 live Colour on the Back, the Belly of a pale Flefh, and the Head Red. It was taken on the Sallow the 17th of May. It fed 'till the ift of Fune, and then went into the Ground, and changed into Cbryfalis $b$, and the 12 th of Auguft came a Moth, the upper Wings $c$ of a fine Yellow, clouded and marked with feveral indented Lines of a dark Colour; the under Side and ander Wings $d$ of a pale Cream Colour.

The Caterpillar $e$ was of a dark Straw Colour. It was found on a great Water-grafs, in the Marnhes near Rotherbith the roth of May; it went into the Ground the x 2 th of the fame Month, and changed into a Chryfalis expreffed at $f$, which produced a Moth the I $3^{\text {th }}$ of 7 une following; it was of the fame Colour of the CATERPILLAR as at $g b$ in the Table. 


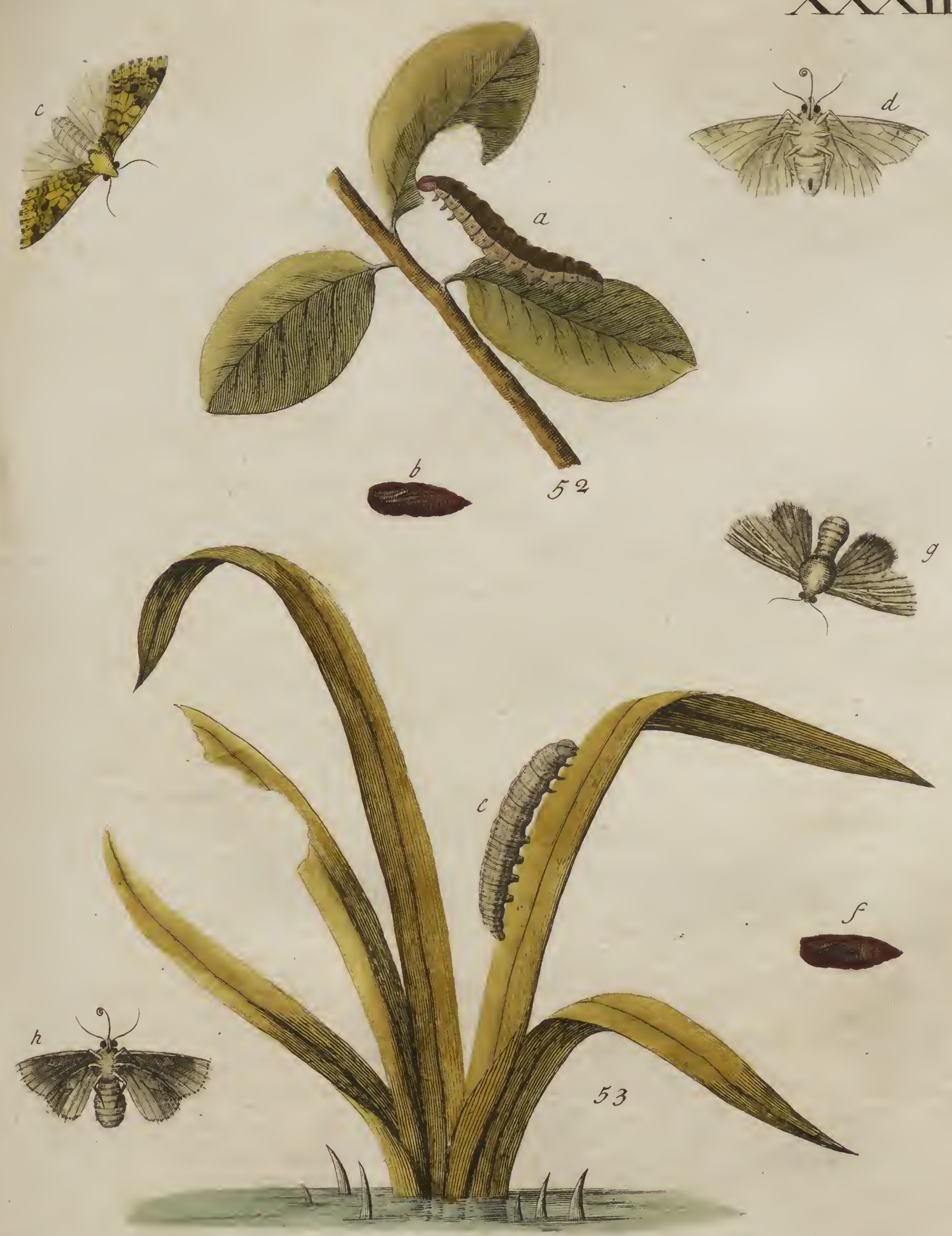

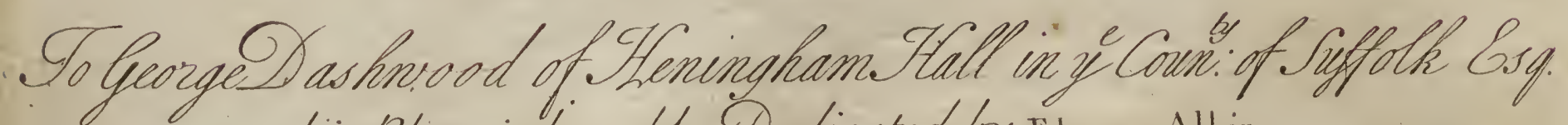
E. albin del. this Plate is humbly Dedicated by Etea zar Albin 

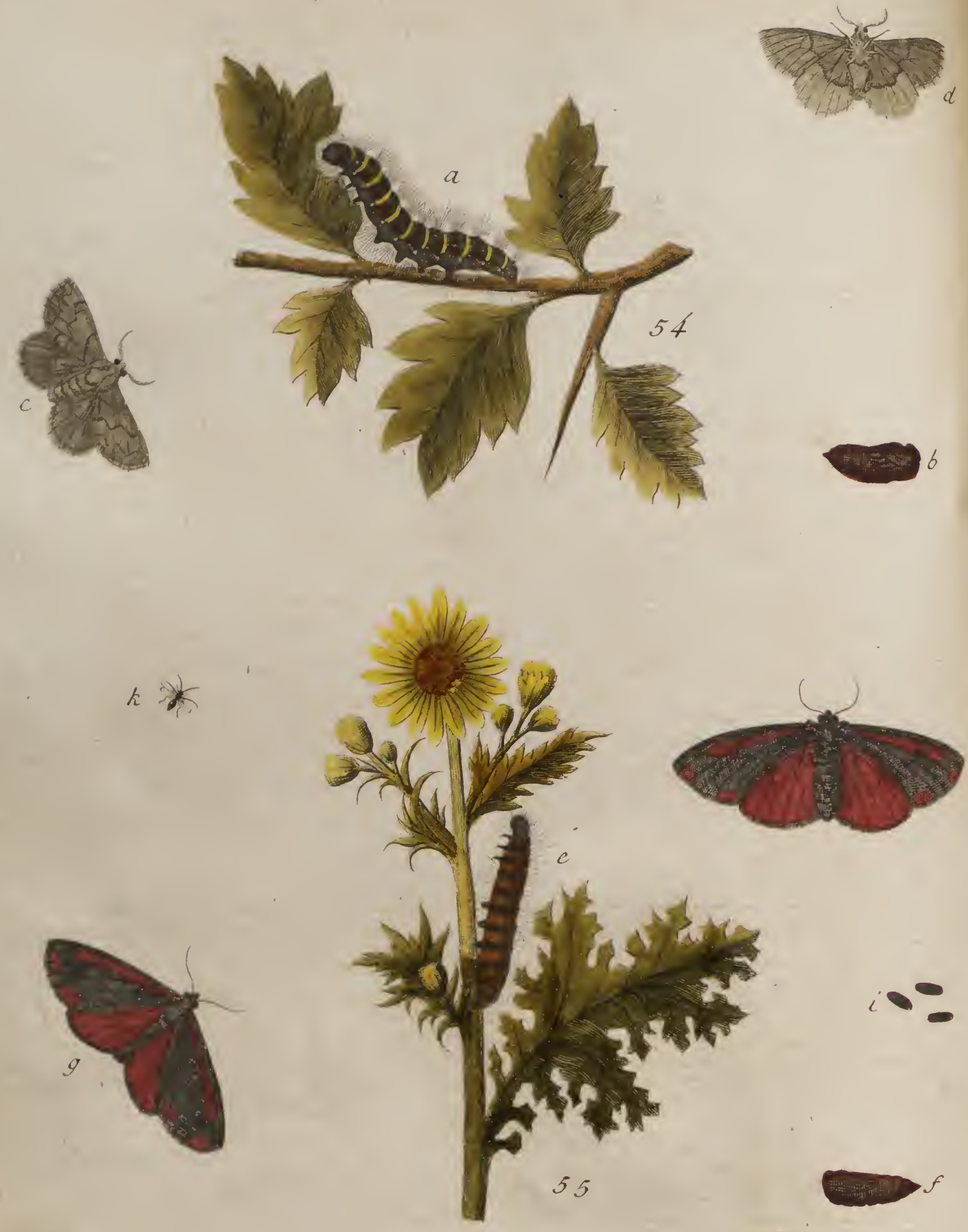

$$
\text { To the Lady. Ietryl }
$$
this plate is humbly ODedicaued by Eleazar Albin . 


\section{T H E}

\section{Description of the Thirty Fourth Plate.}

$\mathbf{T}$

He Caterpillar $a$ in this Table was Black intermixed with Spots of Brown divided with Rings of Yellow on the Back, the Belly was like black Velvet. I found it on the witite-Thorn about the middle of May; it is likewife on black Thorn, Hafle and the Oak, on all which they feed very freely: on the 28th of May it fpun up it felf on the Back-Side of a Leaf in a brown bard Cafe, and changed into a Chryfalis, and the Moth came the 2oth of Auguft; it was of a light Hair Colour with 3 indented Lines a-crofs the upper Wings of a darker Shade; it is exprefs'd at $c d$ in the Table.

The Caterpillar $e$ was of a deep Orange Colour with Rings of Black, it was found on the Ragwort about the 2oth of Fune, on which I fad it; the 27 th of the fame Month it went into the Earth in the Box and changed into Cbrysalis, and the 17 th of May following came a beauliful black and red Moth $g h$. Some of thefe CA TER P L L a r s produced Imall Maggots, which Ipun themfelves up in Cafes of white Silk, and produced the Icbneumon expreffed at $k$. See Lifter on Goddart page $6_{1} . N^{2} 54$. 


\section{T H E}

\section{Description of the Thirty Fifth PLAte.}

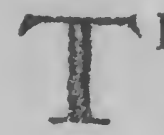

HE CATERPILLAR in this Table was of a reddifh brown Colour on the Back; the Belly of a Flefh Colour, his Feet and Nippers black and very hard and tharp, by which he penetrates into the very Heart of the Willow; I found him in November. Thefe Ca Ter PILlars are fometimes found in the Poplar, A/h or Elm; and Dr. Lifter fays be found it in the Oak. It has been obferved by fome of the Curious, that this mifchievous Infect is 3 Years in its Progrefs from the Egg to the Moth. I was obliged to keep it in a tin Box with fome of the Willow wood, for he eat his way through a Box of Wood I had put him in before; he changed into a Cbryfalis about the Beginning of May, and about the middle of fune came the Moth $c d$, of a dark Hair Colour, ftreaked with White; the Moth is to be found on the Bodies of the aforefaid Trees, toward the latter end of fune. Thefe CA TER P I LLARS ufually lay themfelves up in the Holes which they make in Trees, in pretty thick Webs; when the Moth is ready to come forth, the Chryfalis forces its fore part about half an Inch out of the Tree, otherwife the Wings would be lamed, by brufhing off that Humidity that is provided for their Growth; to prevent this Inconvenience, Nature has in an extraordinary Manner provided this Chryfalis with Atrong Spimule round each Foint, pointing towards the Tail, by which it is enabled to force its fore-part through the Web. See Liffer on Goddart, page 49. Ne 39 . 

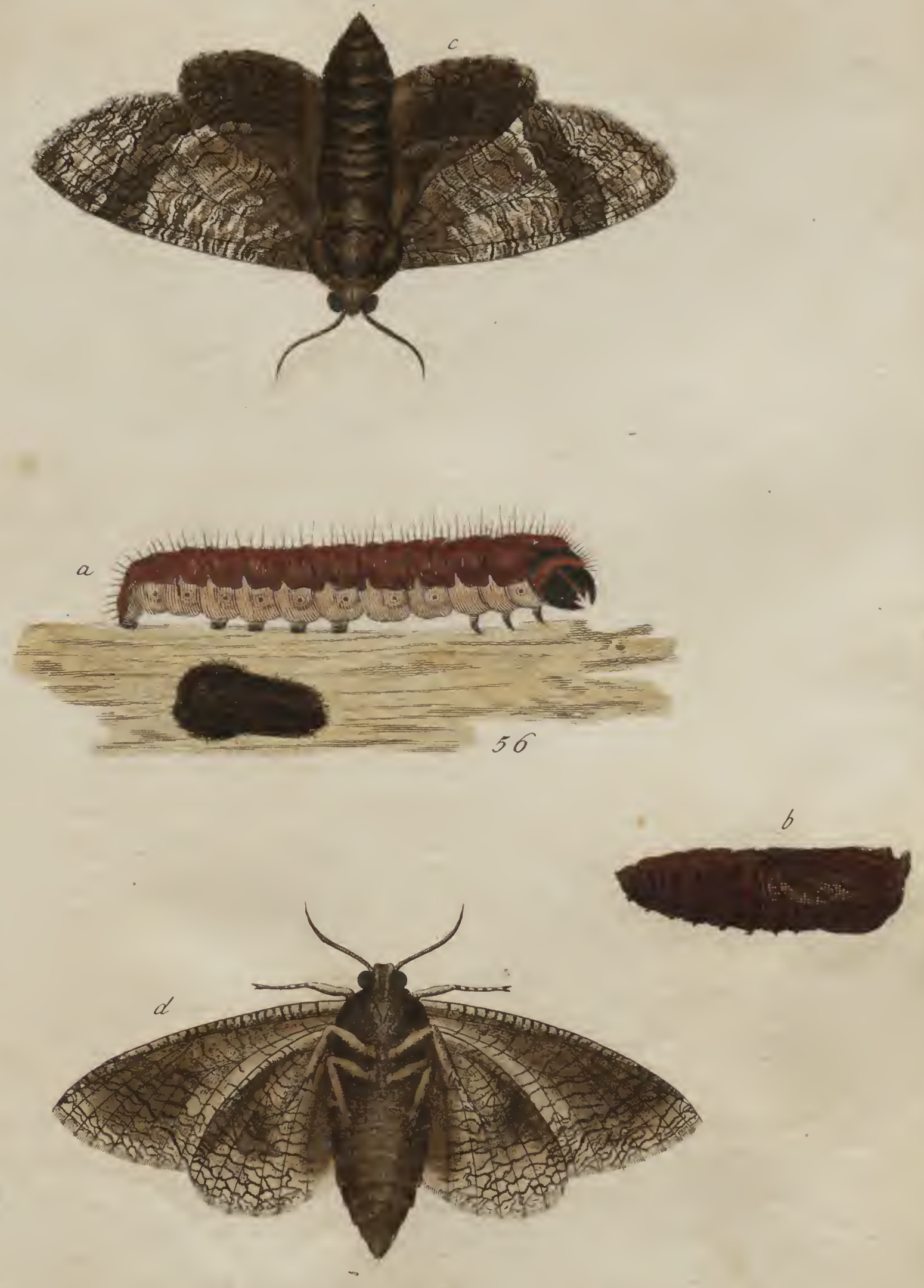

$$
\begin{aligned}
& \text { To the Right Hon orable } \\
& \text { George Earl of Cardigan }
\end{aligned}
$$

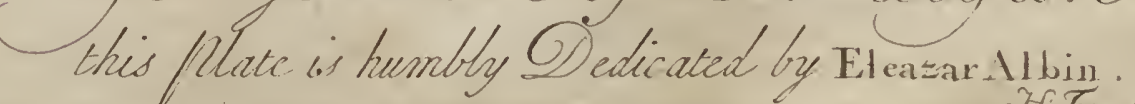




\section{T H E}

Description of the Thirty Sixth Plate.

The Caterpillar $a$ was of a yellowith Green, with a red Head. It was taken folded up in the Leaves of the Nut Tree on the $2 \mathrm{~d}$ of September in a Wood near Woolwich in Kent, it fpun it felf up the 8th of the fame Month, and the 8th of Fanuary following came the Moth of a ftraw Colour mottled with Brown; all the $F e$ males of this Kind that I have kept had their Wings contracted or Thrivell'd up, as is expreffed in the Table. I believe it is natural for them to have their Wings after that manner for in fome Kinds, as particularly in Table 89, $9^{\circ}$, the $F^{\prime}$ males have only the Appearance of Wings, and never go from the Place where they lay in Cbryfalies, but lay their Eggs on their very $W e b$.

The Ca TERPILLAR $f$ was of a full green Colour, the Head dark Red, it was taken roll'd up in the Leaves of the Plumb Tree on the 24th of May, and on the 3 oth of the fame Month it fpun it felf up and changed into Chryfalis $g$; the Motb came the 2 int of $y$ une following, the $W$ ings of a reddifh Brown, the Male $k l$ fomewhat darker than the Female $b i$, as is exprefs'd in the Table. Thefe CaterpilLARS are very nimble in their Motion both forwards and backwards, as I have obferved molt of them are that fold themfelves up in the Leaves; if you force them out of their Leaf they let themfelves fall by a Thread to the next Leaf or Branch, by which, when all is quiet, they climb up to their former Habitation. 
Description of the Thirty Seventh Prate.

7 He Caterpillar $a$ in this Table was of a pale Green. It was taken in the Leaves of the Elder, which it had rolled up like a $W$ afer to fecure its felf from Danger, wherein it lies moft part of the Day, feeding commonly in the Night: It fpun it felf up the 7 th of $A x$ guft in a $W e b$ to the Side of the Box in which I fed it, and remain'd in its CATERPILLAR-ftate 'till the Beginning of $A$ pril, and then changed into a Cbrysalis $b$, and the 15 th of June came the Moth $c d$ of a pale Brown Colour. I had fome of thefe C A TE R P I L A R S which were fly-blow' $d$ by $I c b$ neumons and others by a fmall Sort of the common Flys. The Maggots of each, foon after they came out of the C A TERP ILLARS, changed into Chryfalies at $e g$, in which State they lay till the Spring following, and then produced the Flys $\mathrm{fb}$. See Lifler on Goddart, page 62. $N^{\otimes} 55$.

The CATERPILLAR $i$ is of a pale yellow Green; it was found wrapped up in the Leaves of the Nettle at the latter end of May, after the fame manner as the Elder CA TERPILLAR above-mentioned; it changed the $2 \mathrm{~d}$ of Fune into a black Cbryfalis, and in I 4 Days came a Moth at $l m$, White neatly fpotted with Black; which we commonly call the Magpie. See Liffer on Goddait, page 66. $N^{\mathrm{O}} 6 \mathrm{I}$. 


\section{XXXVII}
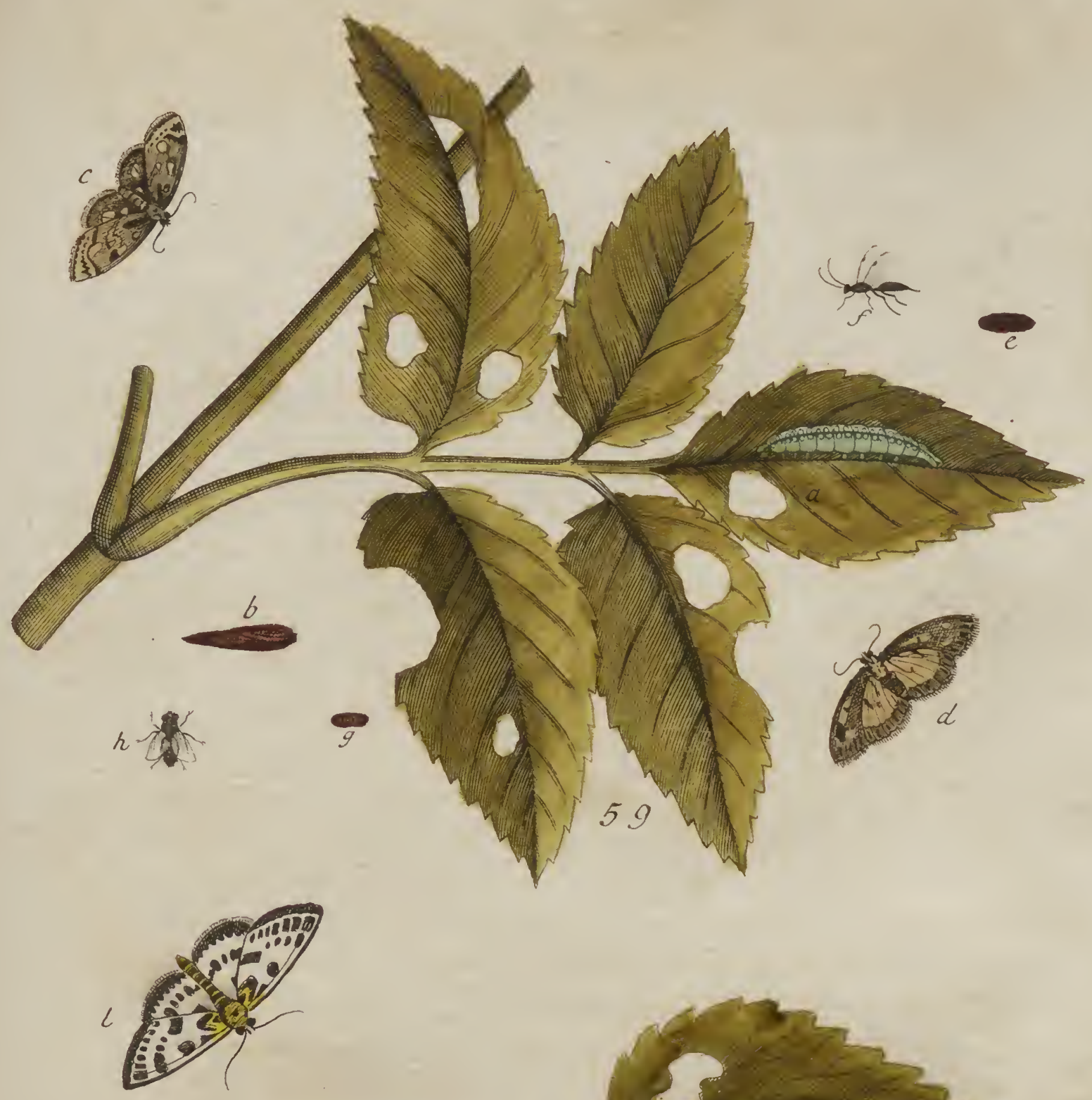

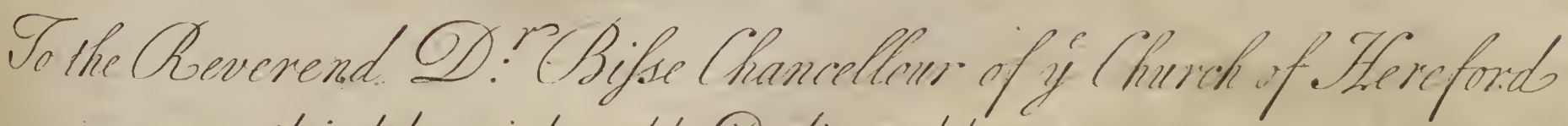
E.abindel. this plate is humbly Dedicated by tisazar Albin. 


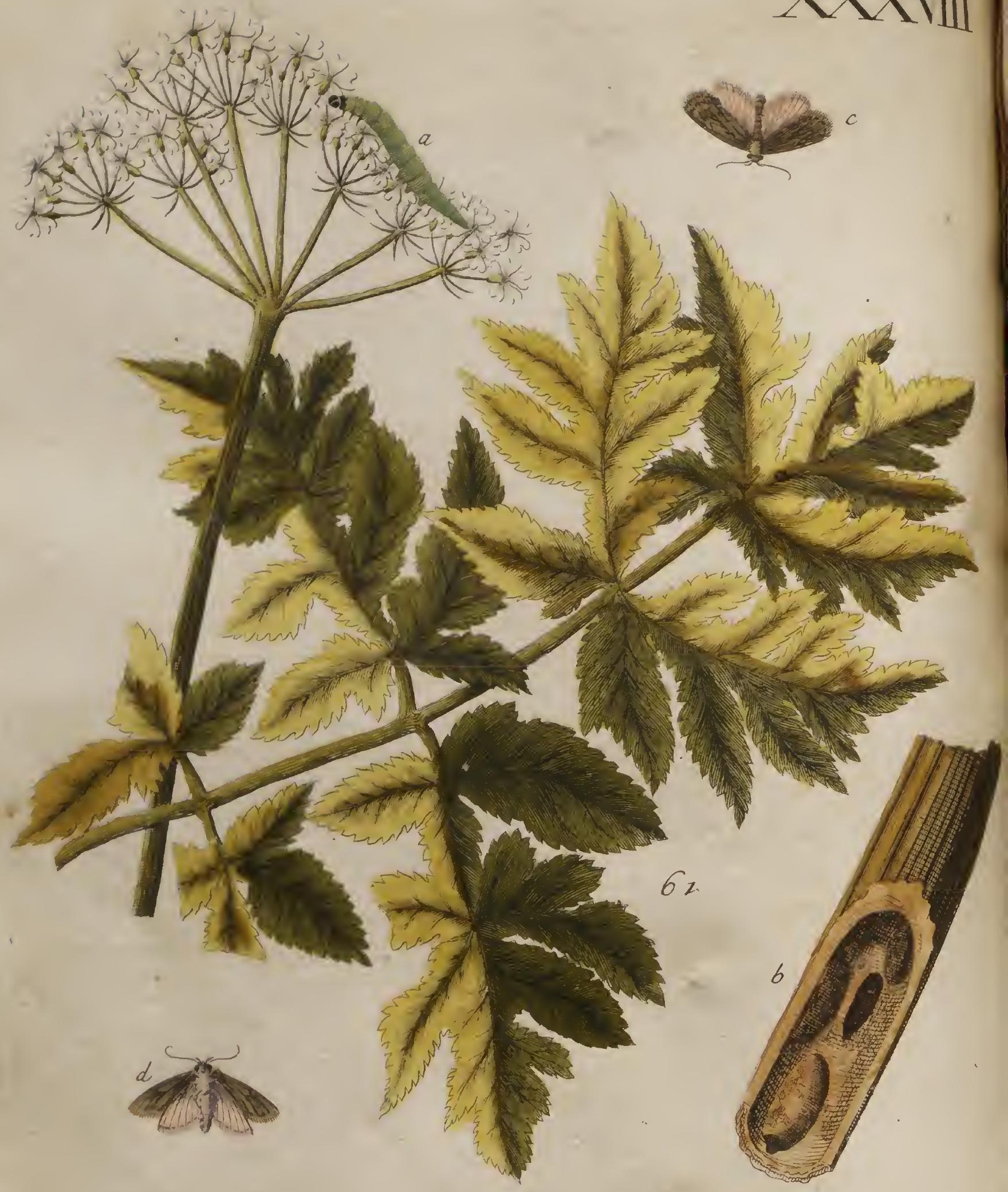

\section{To the Honorable}

Glizabeth flavell now Mrs OBromley this plate is humbly Deflicated by Eleazar Atbin 
Description of the Thirty Eighth Plate.

THE CATERPILAR $a$ in this Table was of a light Green Colour, with fmall Specks of Black. Mr. Dandridge found it feeding on the Flowers of Cowe Parfnep the 3 oth of $\mathcal{F} u n e$, and fed it on the fame in a Box, in which it fpun it felf up and changed into Cbryfalis $b$ the ${ }_{1} 6$ th of $f u l y$. He went fome time after to look for more of thefe Cater pillars, but could not find any tho' he examin'd feveral of the Plants to the very Roots: upon obferving Holes in fome of the Stalks he cut them, and found many of the Cbryfalies fpun up in the hollow part of the Stalks pretty near one another, as is exprefs'd at the Letter $b$ in the Table. The Motb $c d$ came the 12th of Auguft, the upper $W$ ings of a dark Olive, the under Wings and under Side of the Moth of a light Hair Colour. 


\section{T H E}

\section{Description of the Thirty Ninth Prate.}

7. HE CATERPILARS $a$ a in this Table were differing in Colour, the one Yellow with Stripes of a deeper Shade and Spots of Red on each Foint, the other dark Red, fpotted on the middle Foints with Yellow, their Heads Red with a Ring of Yellow round their Necks: I took them at the Beginning of Fune on the Heart-cherry Tree: whey were very numerous on the Pear, Apple, Plumb, and Lime Trees, eating feveral of them bare; they went into the Ground about the middle of the fame Month fpinning themCelves a $W e b$, and changed into a Cbryfalis $b$, and the Beginning of April came the Moth $c d$, of a dusky Yellow friped and motled with Black. The Motb lays her Eggs in the Cracks and hollow places of the Trees. Thefe CATERpILLARS are call'd Loopers, becaule in their walking they draw their Bodies into the Form of a Loop by bringing their Ends together; thefe and molt others of this $K$ ind have a $W e b$ coming from their Moutbs to the Branch, by which they convey themfelves from one Bough to another at their Pleafure. The way of deftroying thefe is by killing the Motbs when firft harched, which are to be found on the Bodies of the aforefaid Trees. See Merian, Vol. 1. page 75. Chap. 37.

The CATERPILLAR $e$ was of the fame Colour with the Older Branches of the Tree fo as fcarcely to be difcerned from the $W_{\text {ood. It }}$ was found the I th of May on the Black-thorn: I fed it 'till the 24 th of thefame Month, at which cime it went into the Ground and changed into Cbrysalis $f$, and the I ith of Auguft following came the Moth gh, of a pale Buff, having a broad Cloud of a darker :Colour a-crofs the middle of the upper Wings, and Spots of the fame round the Eages both of the upper and inder Wings. 

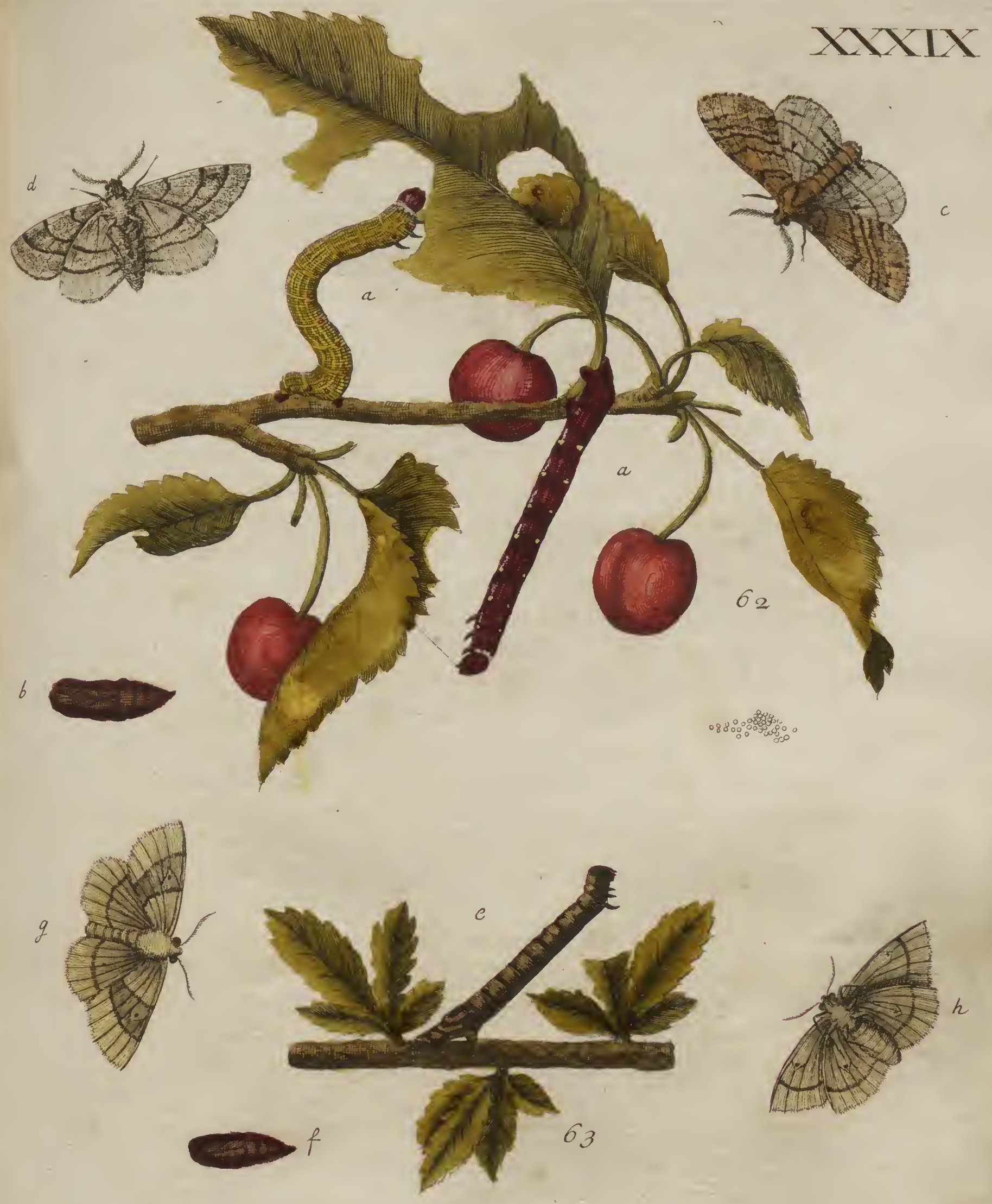

To the Right Hovomabi.e

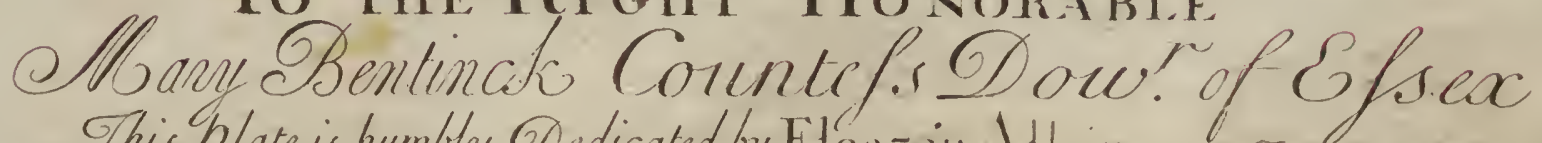

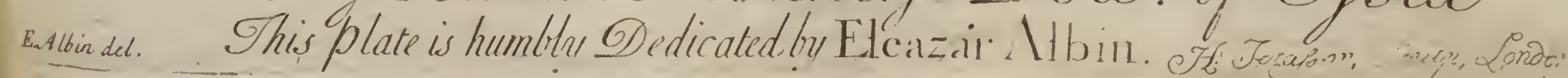



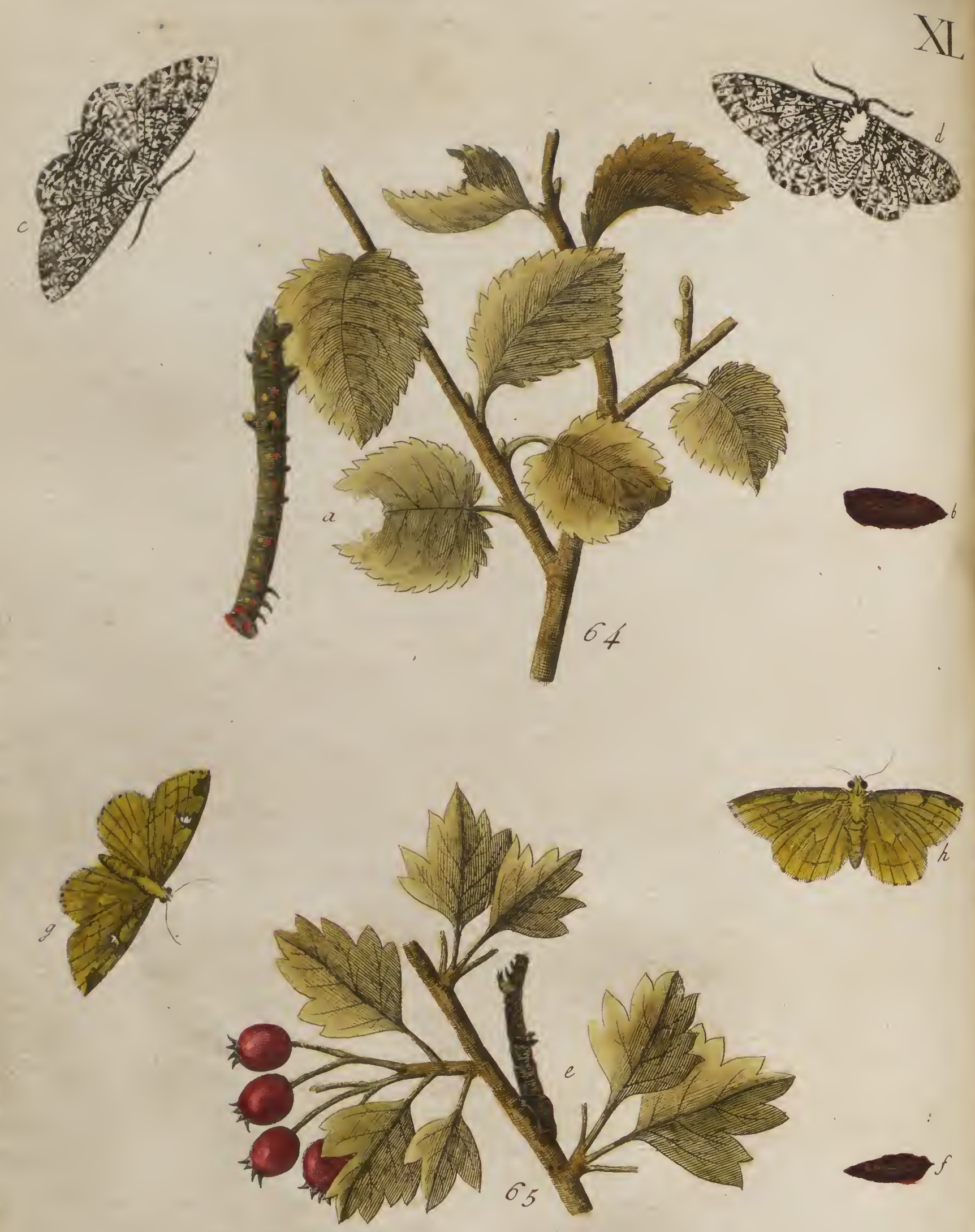

To the Rught Hon orable

Slizabeth obuthr Countefs Don.' of Derby

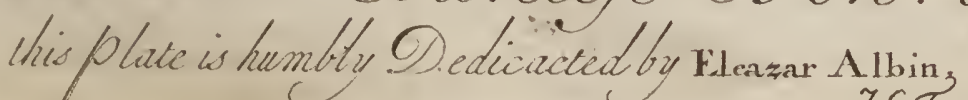




\section{T $\mathrm{H} \mathrm{E}$}

\section{DeSCRIPTION of the Fortieth Plate.}

The Caterpillar $a$ in this Table was of an Olive Green Colour with red and yellow Spots on each Foynt, the Head pale red, it had four Risings or Bunches tipt with Yellow on the Back near the Hinder-part. It was found feeding on the Elm in the Beginning of September. I fed it till the 26 th of the fame Month; it then went into the Eartb in the Box and changed into a Cbryfalis b, of a dark Red Colour, and the 27 th of May following came forth the Motb exprefs'd at $c d$, being White motled with Black.

The CATERPILlar $e$ was finely marked with divers Colours, having Rifings or Bunches on the middle of its Back. It was found on the White-thorn in September, and the 17 th of the fame Month it fpun it felf up in the Leaves and changed into a Cbrysalis, and remained in that State till the Beginning of April, at which time came forth a yellow Moth marked as at $g b$ in the Table. 


\section{T H E}

\section{Description of the Forty Firf Plate.}

\section{$\mathbf{T}$}

HE Caterfillar, $a$, in this Table was found on the Oak on the 19th of Fune near Highgate, it was about the bignefs of the fmaller Figure in the $\mathrm{Ta}$ ble, and of a brown Colour; after fome time it changed its $S k i n$, and grew to the Bignefs of the largeft exprefs'd at $a$, it was of a pale brownifh Afh Colour, with four Rifings or Bunches on the Back, the hindmoft of which was tipt with Red, as were alfo the Holders next the Tail; it went into the Earth the roth of $\mathcal{F} u l y$, and changed into a Chryjalis of a dark red Colour; where it remain'd till the latter end of May, at which time came a Moth very like that in the foregoing Table. 2. Whether they may not be Male and Female.

The Caterpillar, $e$, in this Table was of a pale $\mathbf{O}$ live Colour, it was taken on the Black-thorn, at the Beginning of May, and the 16 th of the fame Month it went into the Earth, and with the fame work'd it felf a Cafe, and changed into a Cbryfalis, and on the $22 \mathrm{~d}$ of June following came a Moth of a pale Buff Colour, having a broad Cloud of a darker Colour crofs the middle of the upper. Wings, and Spots of the fame round the Edges of the upper and under Wings. 


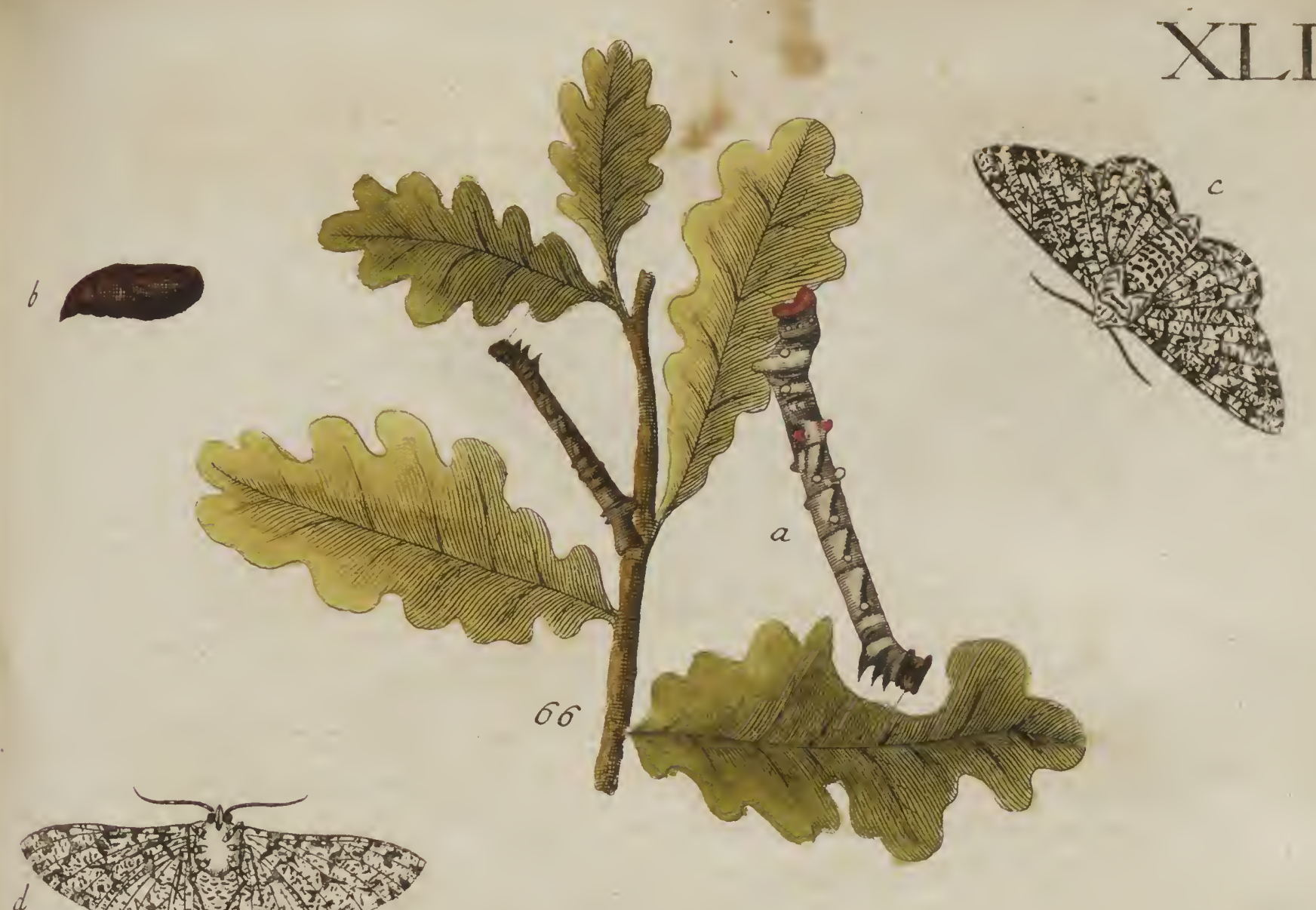

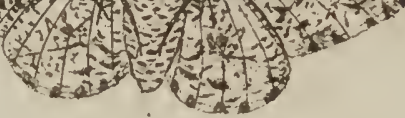
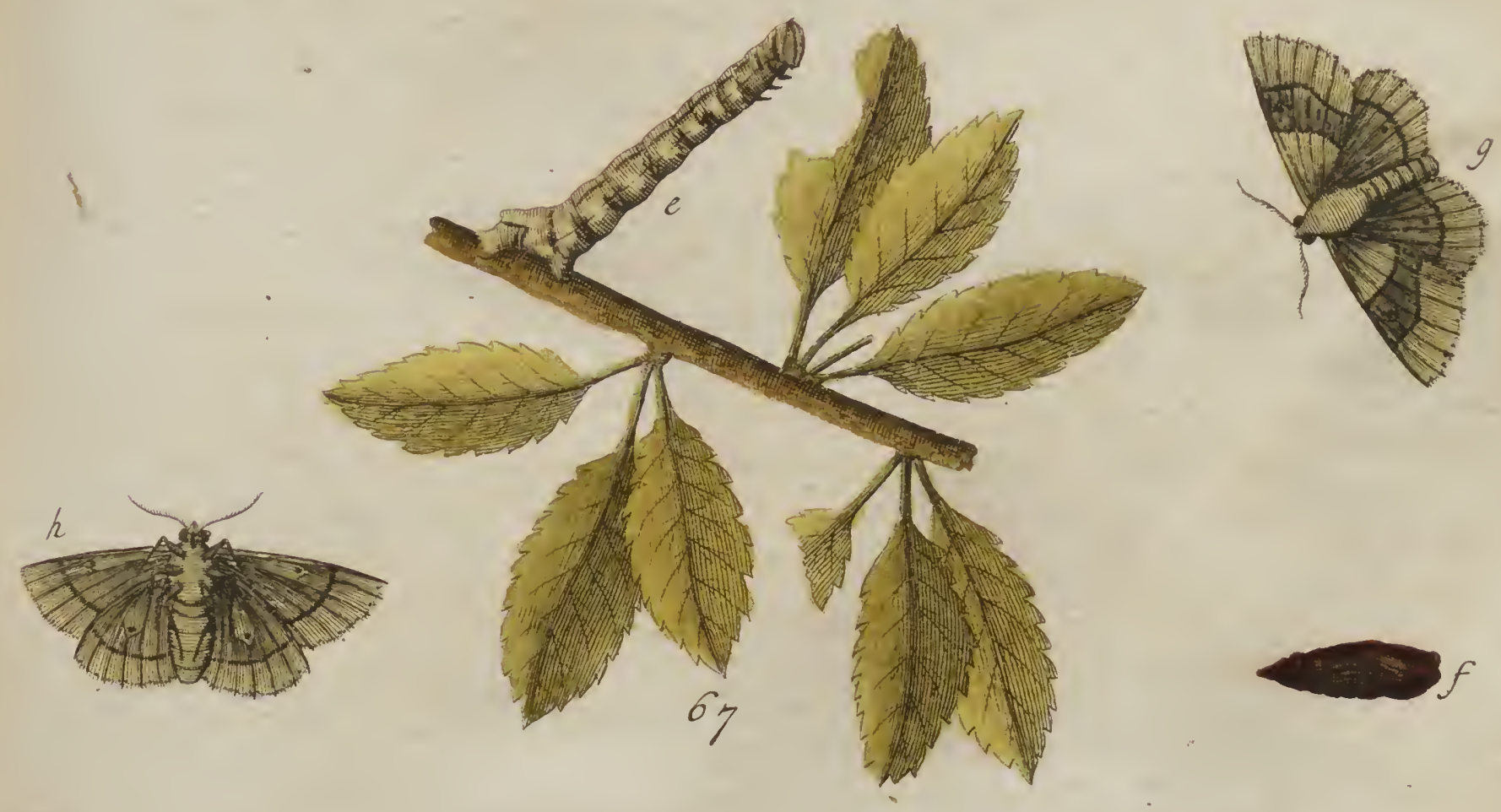

To the Right Hon orabie

The fadre triture fomersett 

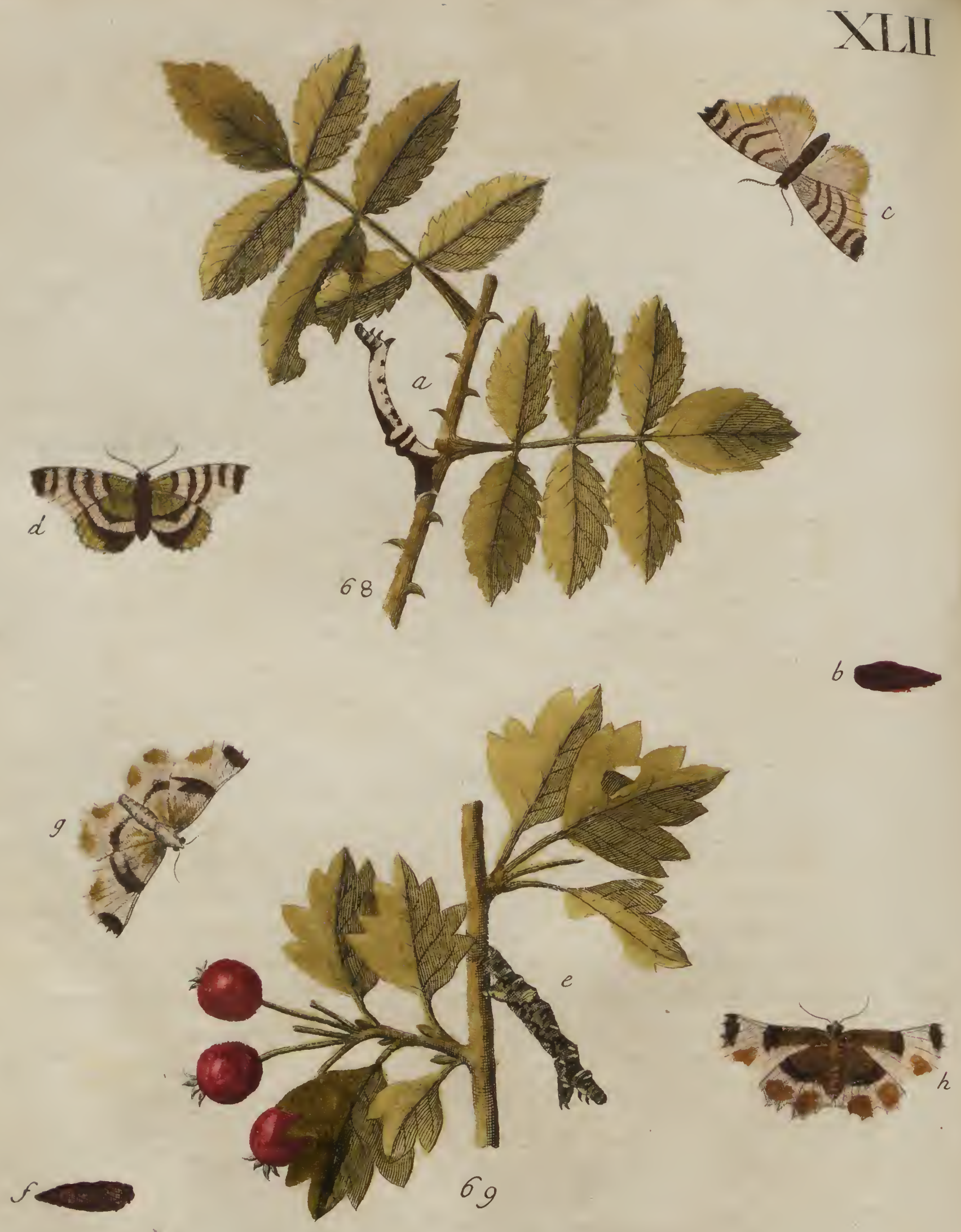


\section{TH E}

Description of the Forty Second Plate.

The Caterpillar, $a$, in this Table was of a pale 1 Cream Colour, thadowed on its Back with Brown and fpotted with Red. It was found on the Wild-Rofe between Iflington and Highgate; the Head was much fmaller than ufual; it fpun it felf up between a Leaf and the Side of the Box on the $22 \mathrm{~d}$ of $\mathcal{F} u n e$, and changed into a Cbrysalis, $b$; and the roth of Fuly came a Motb at $c, d$, of a flem Colour Atreaked with Brown.

The Caterpillar, $e$, was of a muddy Green Colour, motled with darker Colours like the Bark of a Tree; the bindermoft Feet of this CATERPILLAR are remarkably. longer than in moft others that I have obferved, which it draws in or thrufts out as it has occafion. It was found on the White-thorn the roth of September, and on the 24th of the fame Month it fpun it felf up in the Leaves, and changed into Cbryfalis, $f$; and the I 5 th of May came a Beautiful clouded fallop-winged Moth at $g, b$, in the Table. 
DEScRIPTION of the Forty Third PLATE.

$\mathbf{T}$

HE Caterpillar, $a$, in this Table was Brown, with five large light-coloured Spots on its Sides, the Head Red, and near. its Tail it had two Rifingsending in Points of the fame Colour. It was taken on the Whitethorn the 8th of May near Lew/ham in Kent. I fed it 'till the $23 \mathrm{~d}$ of the fame Month; it then went into the Earth in the Box, and changed into Chryfalis, and the 26 th of September came a Moth, $b, c$, of a pale red and yellow Colour.

The Caterpillar, $d$, in this Table was of a pale Cream Colour fpotted with Black and Red. It is commonly found on the Goofe-berry and Currant Trees at the Beginning of May, and the $22 \mathrm{~d}$ of the fame Month it fpun up its felf, and changed into a red Chryfalis with Rings of Yellow; and the I 2 th of fune came forth a black and white Motb intermixt with Yellow; the Eggs of this Moth, foon after they are laid, hatch, and the young CATERPILLARs live all Winter in Places of Shelter, and in the Spring begin to feed as foon as the Budsopen; the way to preferve the Trees from thofe CATERPILLARS is by cleanfing and thaking them when the Snow is upon the Ground. See Lifter on Goddart, page I3. Ne 9. Merian Vol. I. Chap. 29. 

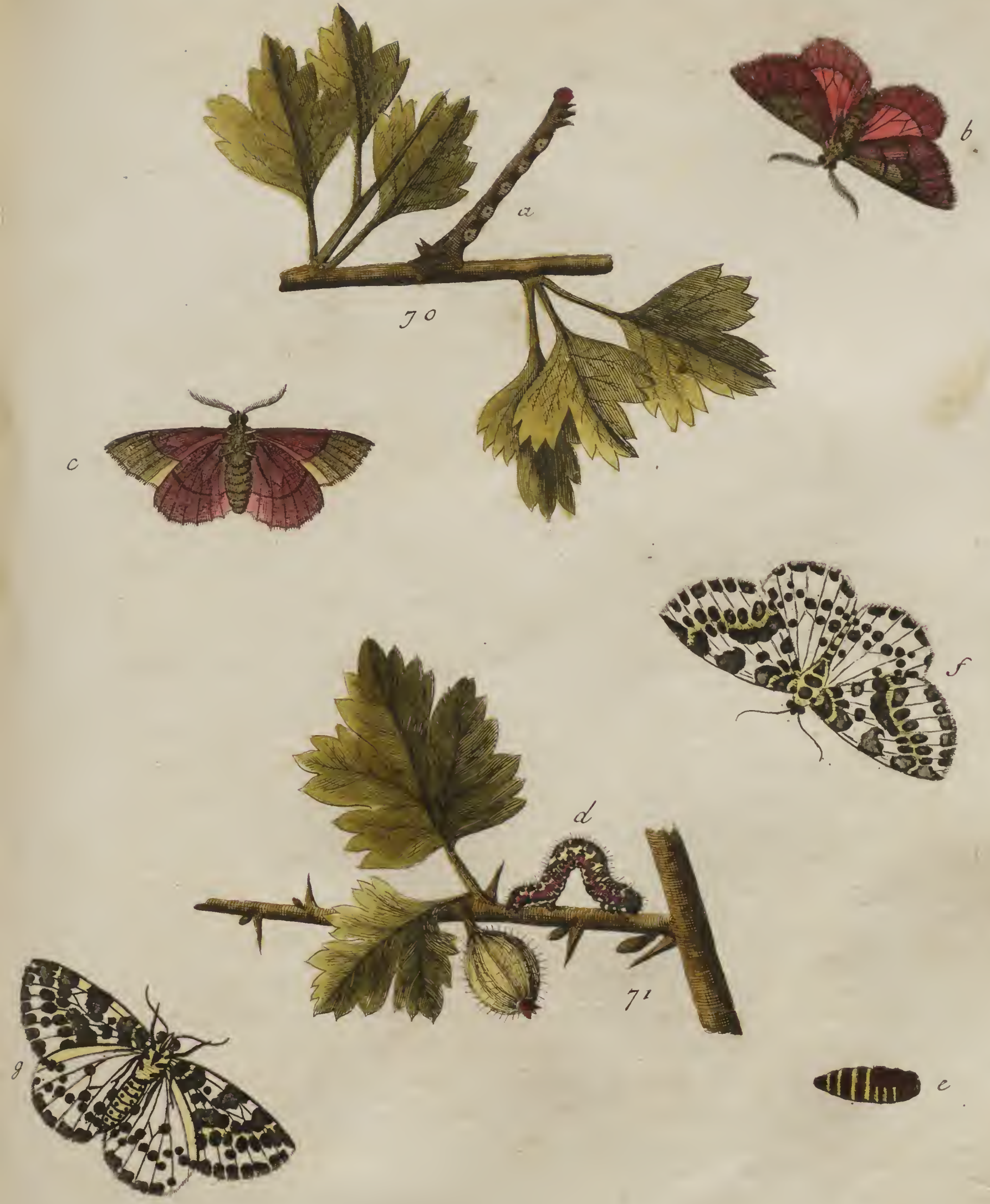

$$
\text { So. Mrs Bovery of SFlaxlen }
$$




\section{T H E}

Description of the Forty Fourth Plate.

7 HE CATERPILlar, $a$, in this Table was of a dark Colour fpotted with White, with a red Head, (I had fome of this Sort almoft all White, others light Alh Colour, others almoft Black.) It was taken on the Whitethorn the $24^{\text {th }}$ of May near Hornfey-wood. I fed it till the i 2 th of Fune, at which time it went into the Ground, and changed into a Chryfalis, $b$, and at the Beginning of April came the Moth, $c, d$, of a pale yellowifh Colour, hadowed and fpotted with deeper Shades of the fame.

The Caterpillar, $e$, was Flefh Colour, the Head dark Brown, with feveral Streaks and Spots of the fame on the Back and Sides. It was taken on the Sallow the isth of May. I fed it till the $13^{\text {th }}$ of $F$ une it then went into the Ground, and changed into a Cbryfalis at $f$; the Moth, $g, b$, came the $9^{\text {th }}$ of Fuly the upper Wings of a dark Yellow, the under Wings and under Side of a light Hair Colour. 


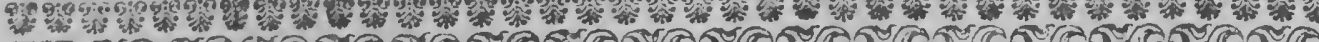

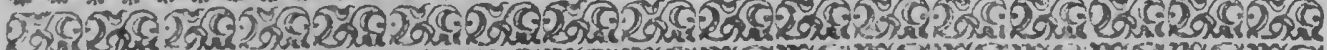

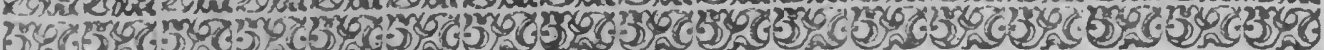
1) 20

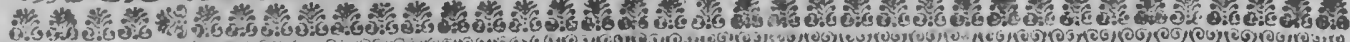
20

\section{T $\mathrm{H} \quad \mathrm{E}$}

\section{DESCRIPTXON of the Forty Fifth Plate.}

7 HE Caterpillar, $a$, in this Table, was of a Seagreen. It was taken on the White-thorn the 12 th of May near Peckbam, and the $14^{\text {th }}$ of the fame Month it went into the Ground, and changed into a Cbryfalis; and the Moth came forth the 25 th of September, the upper Wings, $b$, were of a light Brown, with dark Stripes a-crofs them, the under Wings $c$ of a pale Yellow.

The Caterpillar, $d$, was of a yellowifh Green. It was found feeding on the White-thorn near Eltham in Kent on the 3 oth of May, and the roth of June it fpun up between the Leaves, and changed into a Chryfalis, and the Moth, $f, g$, came forth the 26 th of the fame Month. 

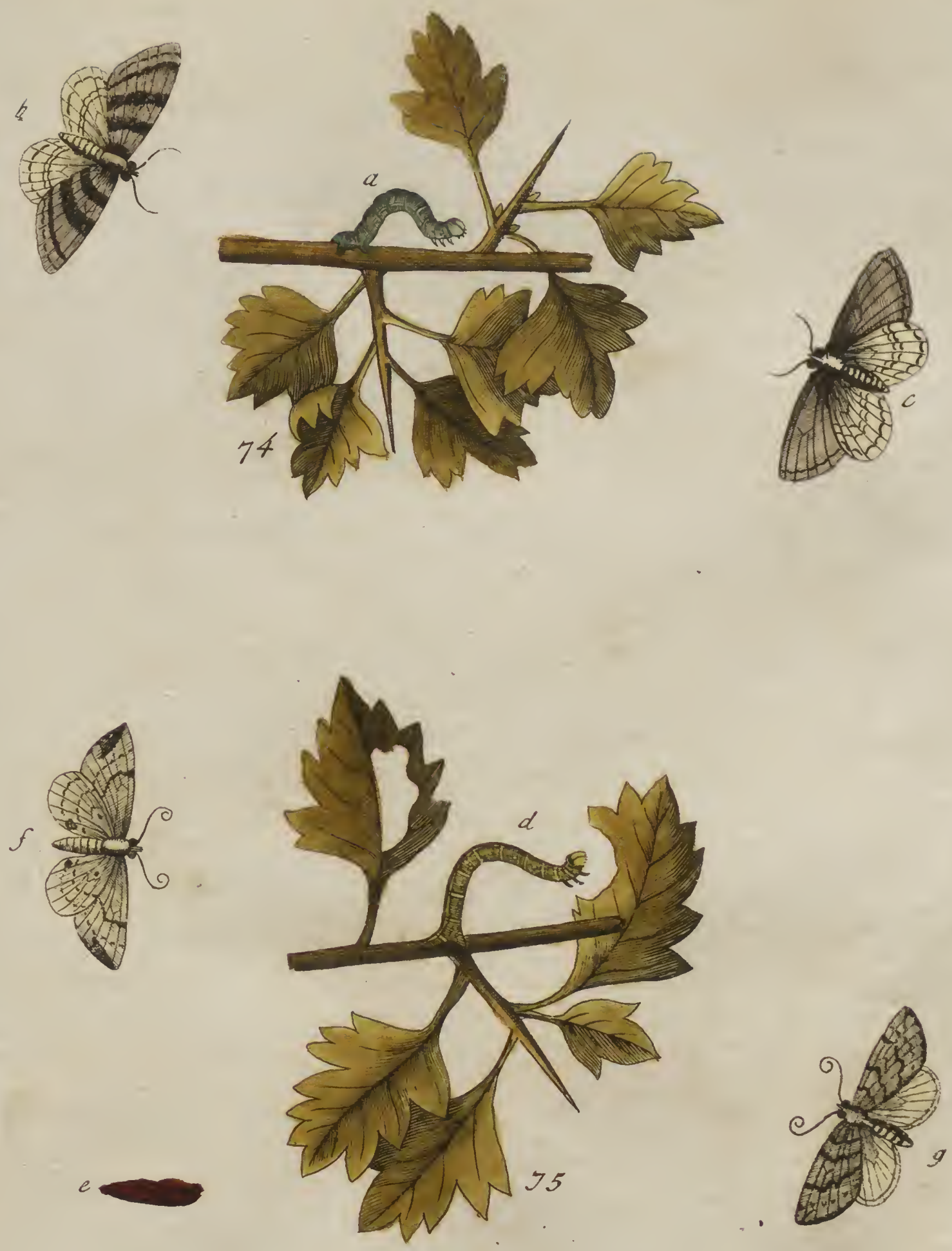

$$
\text { Teml: Mlary Goupy }
$$




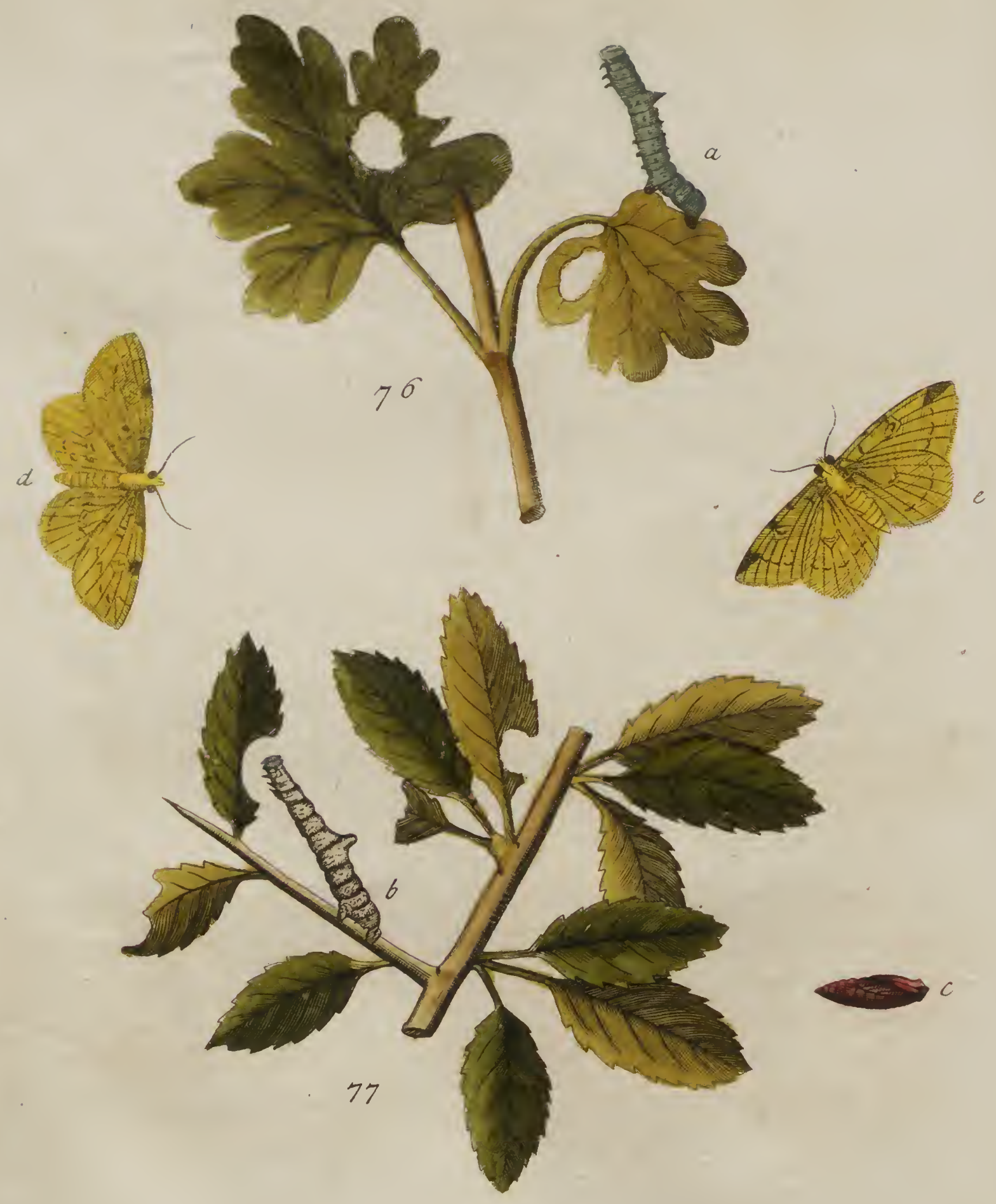

$$
\text { Joc M. Mlontand }
$$

this plake is humbly.D cdicated by EdeazarAthin 


\section{T H E}

\section{Description of the Forty Sixth Plate.}

THE CATERPILAR, $a$, in this Table was of a dark Green Colour, having a Bunch or Rifing on the middle of its Back, and three fmall Bunches on each Side near the firft Holders. It was taken feeding on the Maple near Highgate; about the middle of September, and the 24th of the fame Month it fpun it felf up. to the Side of the Box, and changed into a Cbryfalis, remaining in that State 'till the I 2 th of February, at which time came forth a. Beautiful yellow Moth, $b, c$.

The Caterpillar, $b$, was almoft of the fame Colour with the Twigs of the Black-thorn, on which it was taken the 2 int of May, and on the 28th of the fame Mont it it fpun it felf up in a white $W e b$ in the Leaves, and changed into a Cbryfalis, $c$; the 2 int of Fune it produced the fame Motb as above. 


\section{T $\mathrm{H} \mathrm{E}$}

Description of the Forty Seventh Plate.

The Caterpillars, $a$ a, in this Table were of different Colours, fome Green and Yellow, others Purple and Yellow. They werc found on the Currant

Trees at the Beginning of April, I fed them till the $22 \mathrm{~d}$ Day of May; at which time they went into the Ground and changed into Cbryfalies, and on the 17 th of fune came forth a Moth of a Ruffet Colour ftreaked and fpotted with Black in the upperWings; one of the CATERPILLARs produced the Icbneumon, $e$; thefe CA TERPILLARS are hatched at the latter end of the Year and live all Winter. See Liffer on Goddart page 19. $N^{\circ}$ I2. Merian, Vol. 1. Chap. is.

The CATERPILLAR, $f$, was very elegantly marked with divers Colours. It is often found on the Garden and Wild Orach at the latter end of Auguft. I fed it till the I 6th Day of September, at which time it went into the Earth in the Box, and changed into a Cbrysalis, and on the 11 th of fuly following came rhe Motb of the Colour of a wither'd Leaf. 


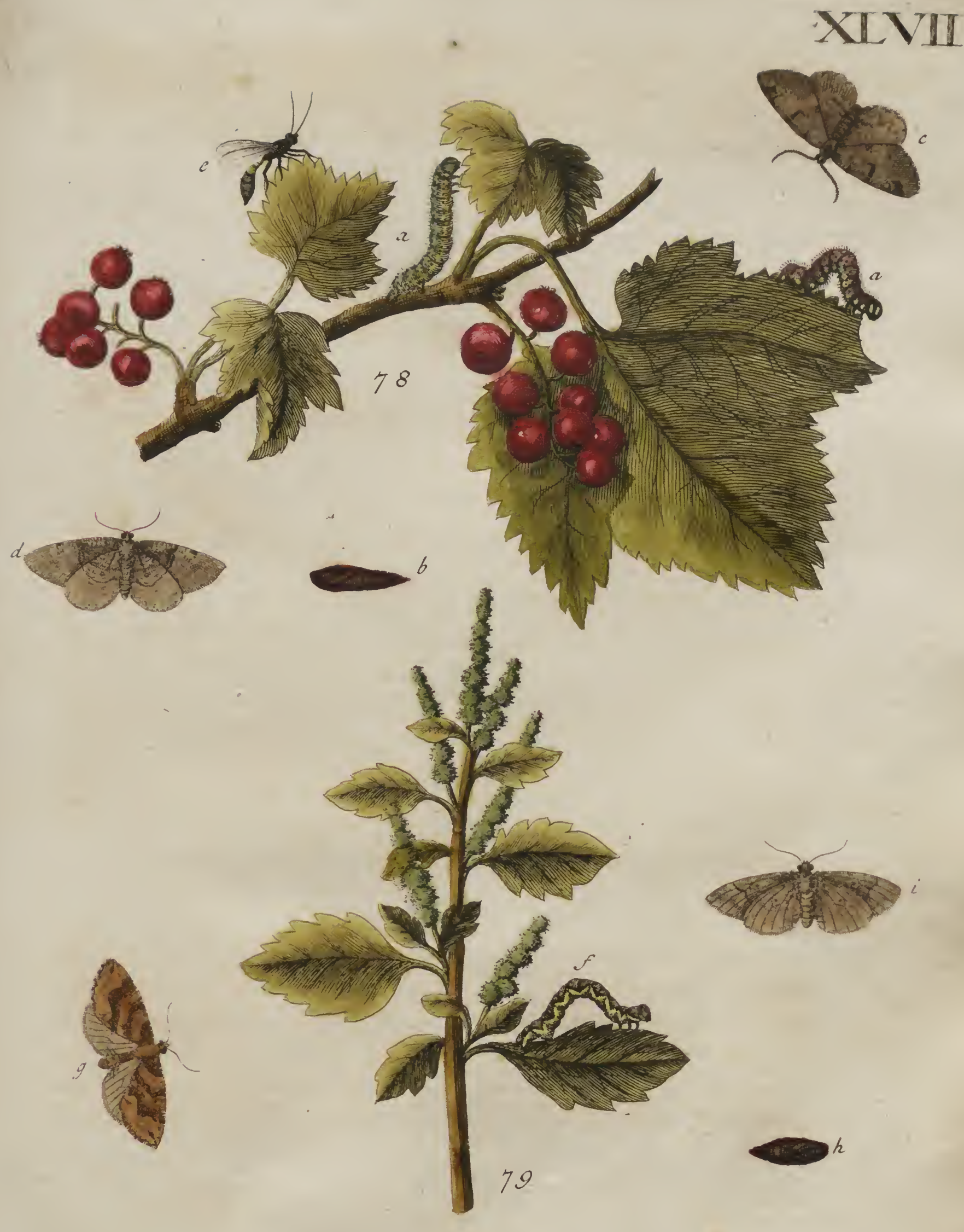

Tothe Right Hoxorable

Glizabethe eymour Gountefs of Thomond this plate is hmbly Dedicated by Elcazar. Albin.

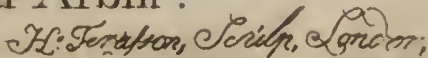



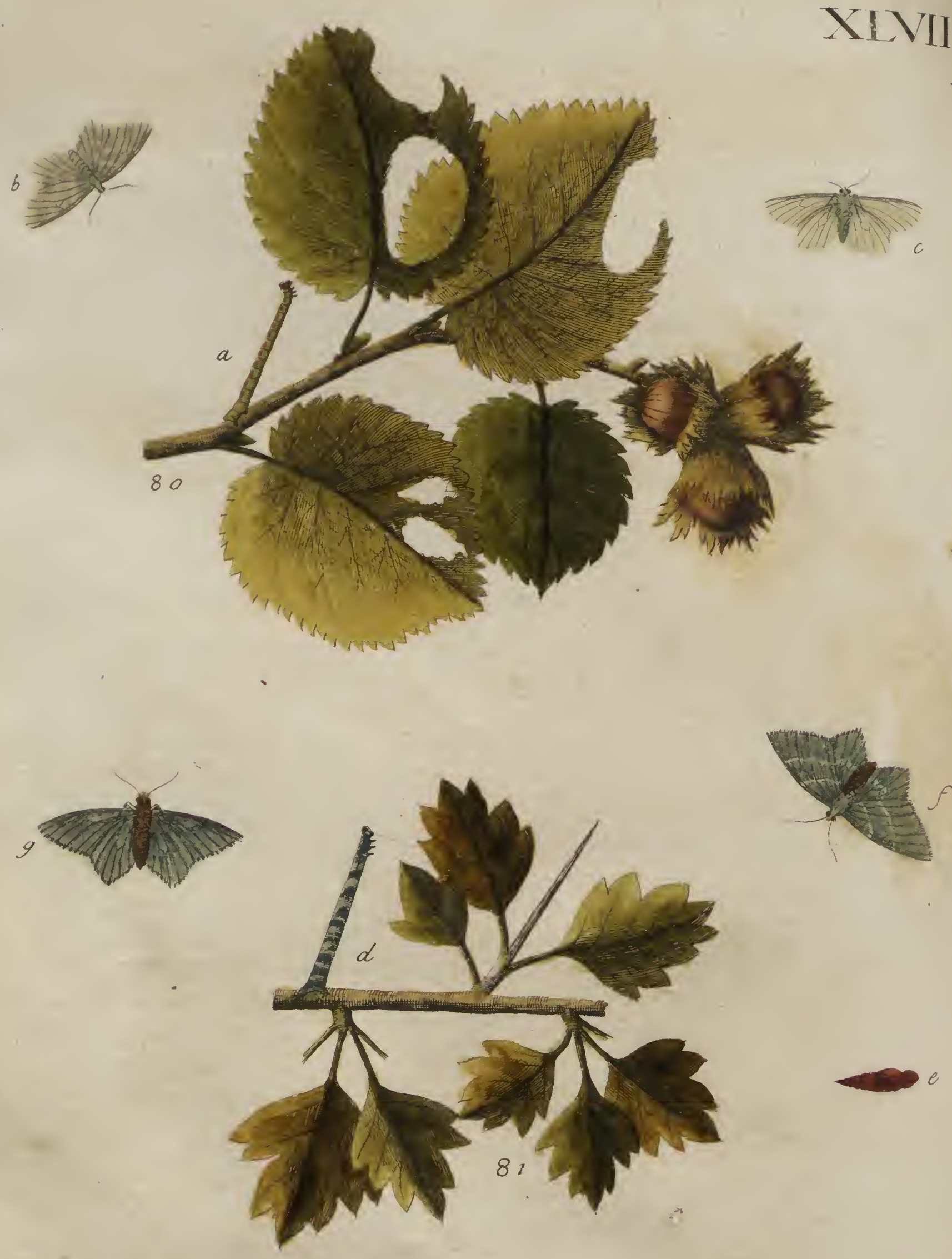

c

$$
\text { T. M. ElizabethHerbert }
$$


DESCRIPTION of the Forty Eighth PLATE.

$\mathbf{T}$

HE CATERPILlar, $a$, in this Table was of a yellow Green Colour, the Head Red with Spots of the fame on the Back. It was taken on the Hafle about the middle of Auguft, on which it fed till the $2 \mathrm{~d}$ of September, and then fpun it felf up and changed into a Cbryfalis, in which it remained till the 2oth of February, then came forth a fmall Green Moth, $b, c$.

The Caterpillar, $d$, was Greenifh with dark Clouds. It was found feeding on the White-thorn, about the latter end of April, near Hornfey-wood; on the roth of May it fpun it felf up by gathering or drawing the Leaves together with a thin $W e b$ in which it changed into a Cbryfalis, e; the Moth $g, f$, came the rf of 7 une following, being of a blueifh Green Colour with two Streaks of whitih Green a-crols the upper Side of the Wings. 


\section{T H E}

Description of the Forty Ninth Plate.

ThE Caterpillars, $a, a$, in this Table are of 1 divers Colours, fome pale Brown, fome Flefh Colour, others Green. They were taken on the Oak on the 23d of Anguft near Muzzle-bill, and on the 28th of the fame Month they tied themfelves up after the Manner of the white Butterfly, Table Ift, to the Sides of the Box with their Heads upward, and changed into Cbryfalies, $b$, of a deep Green, with a red Spot at the End of the Tails; the Moth, $c, d$, came the $29^{\text {th }}$ of September, it was of a Flefh Colour.

The Caterpillars, e, were differing in Colour, fome Brown, others Green, all of them having Red Heads. They were found on the wild Rofe on the 29th of May near HornSey; and the r 4 th of Fune they went into the Earth in the Box, and changed into Cbryfalies, and the $2,1 \mathrm{t}$ of $F e-$ bruary came the Moth of a dark Brown Colour. 


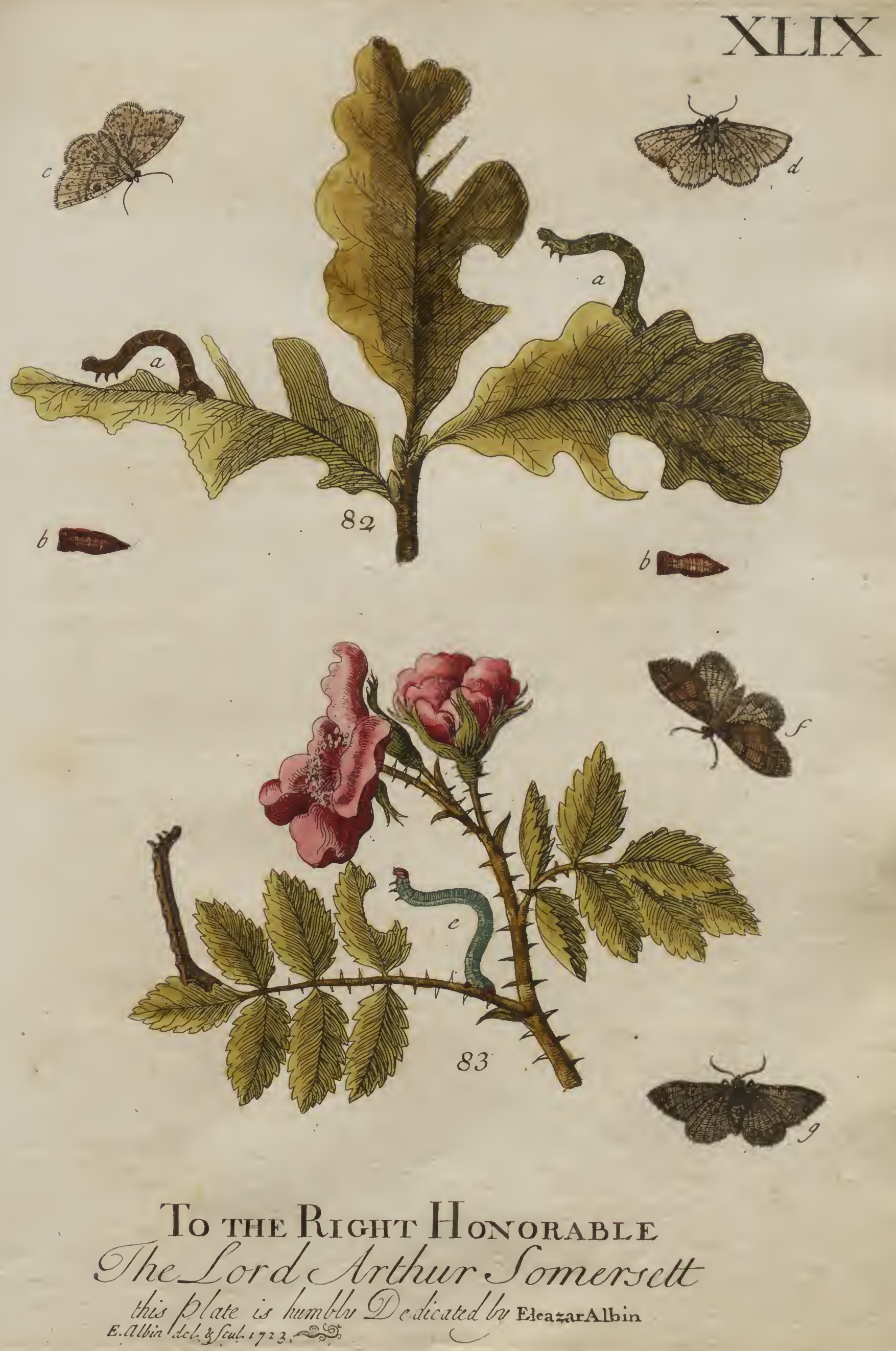



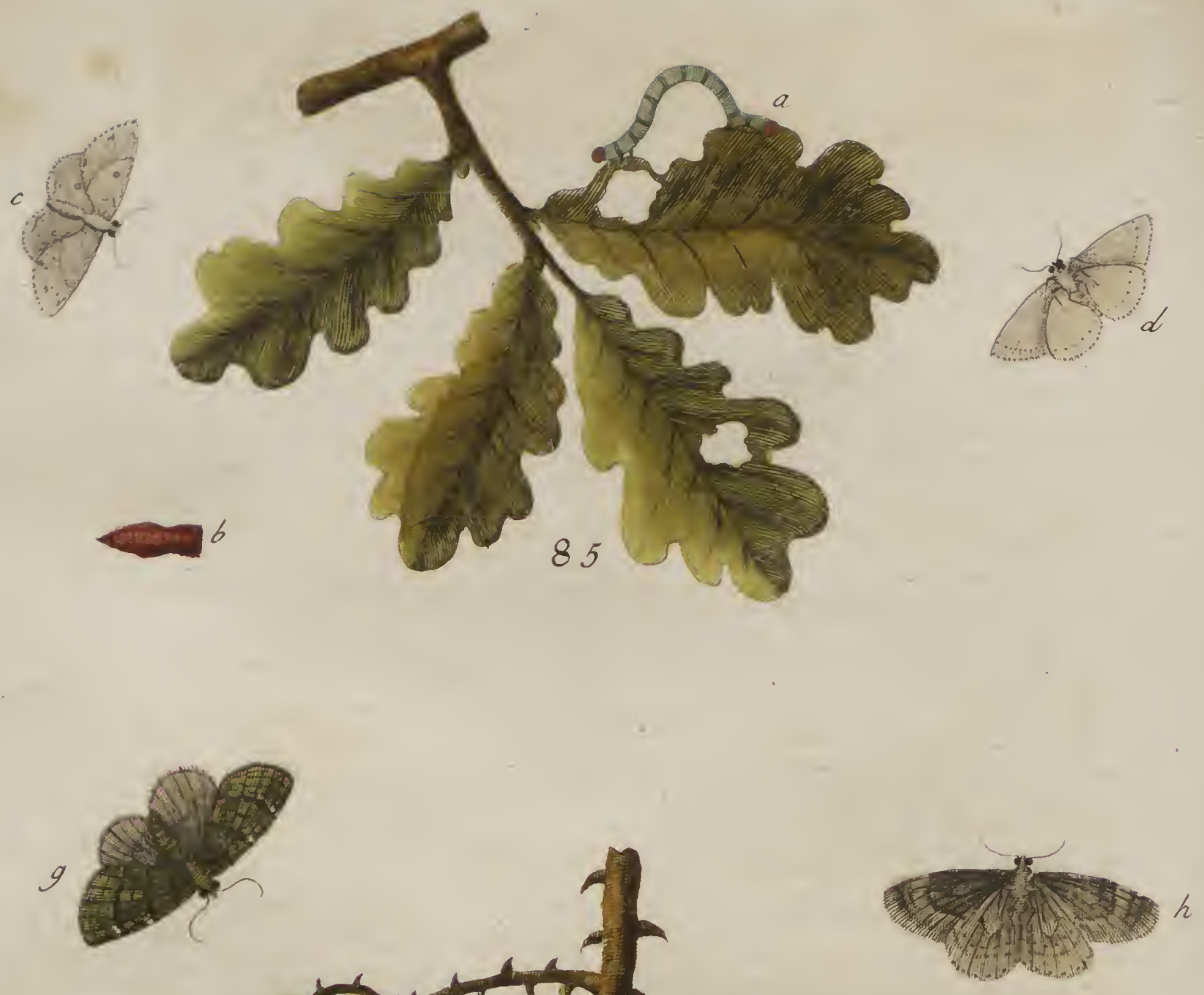

\section{To the Hon orable. $m^{\text {rs }}$ Ann Comersett}

s.asbin dew this plate is humbly Od dicated by Eleazar Abin. 
Description of the Fiftieth Plate.

ThE CAterpillar, $a$, in this Table, was of a Seagreen, the Head and Tail Red. It was taken the 28 th of Fune feeding on the Oak, and the 3d of July it ryed it Self up after the manner of the white Butterfly, Table the I t t, and changed into a Cbrysalis, the Head of which feemed as if cut off, as is expreffed at $b$; in the Table, the 2 Ift of Fuly came forth a Moth of a pale Flefh Colour, with fmall Spots and Circles in the Wings.

The Caterpillar, $e$, was of a yellowifh Green, the Head of a deep Green, with Spots of Red on each Foint near the Back, and two Points of the fame Colour ftanding upright near the Tail. It was taken the 14 th of July on the Bramble or Blackberry-bufh near Cbifelburft in Kent, and the 28th of the fame Month it made it self a House by drawing or Spinning the Leaves together with a thin $W e b$, in which it changed into a Cbryfalis, $f$, and the 2gth of Aiguft came a Moth, $g, b$, the upper Wings Green, the under Wings and under Side of a Hair Colour. 
The Description of the Fifty Firft Plate.

THE Caterpillar, a, in this Table I was Green. It was found feeding on the Radifh about the middle of $\mathscr{F}$ une, they alfo feed on Cabbage, Horfe-radifb, Crefles, and Scurvygrafs; at the latter end of the fame Month it tied it felf up by the Tail, and crofs the Middle, and the I 3 th of Fuly came the Butterfly. The Male, $c, d$, and Female, e, $f$, are very like the Butterflies in the firft Plate in Marks and Colour, but confiderably lefs. There is alfo another white Butterfly frequent in Woods, a great deal lefs than this; the Cater PILLAR which it produces, I cou'd never yet find. See Liffer on Godart, page 12: No 8. 


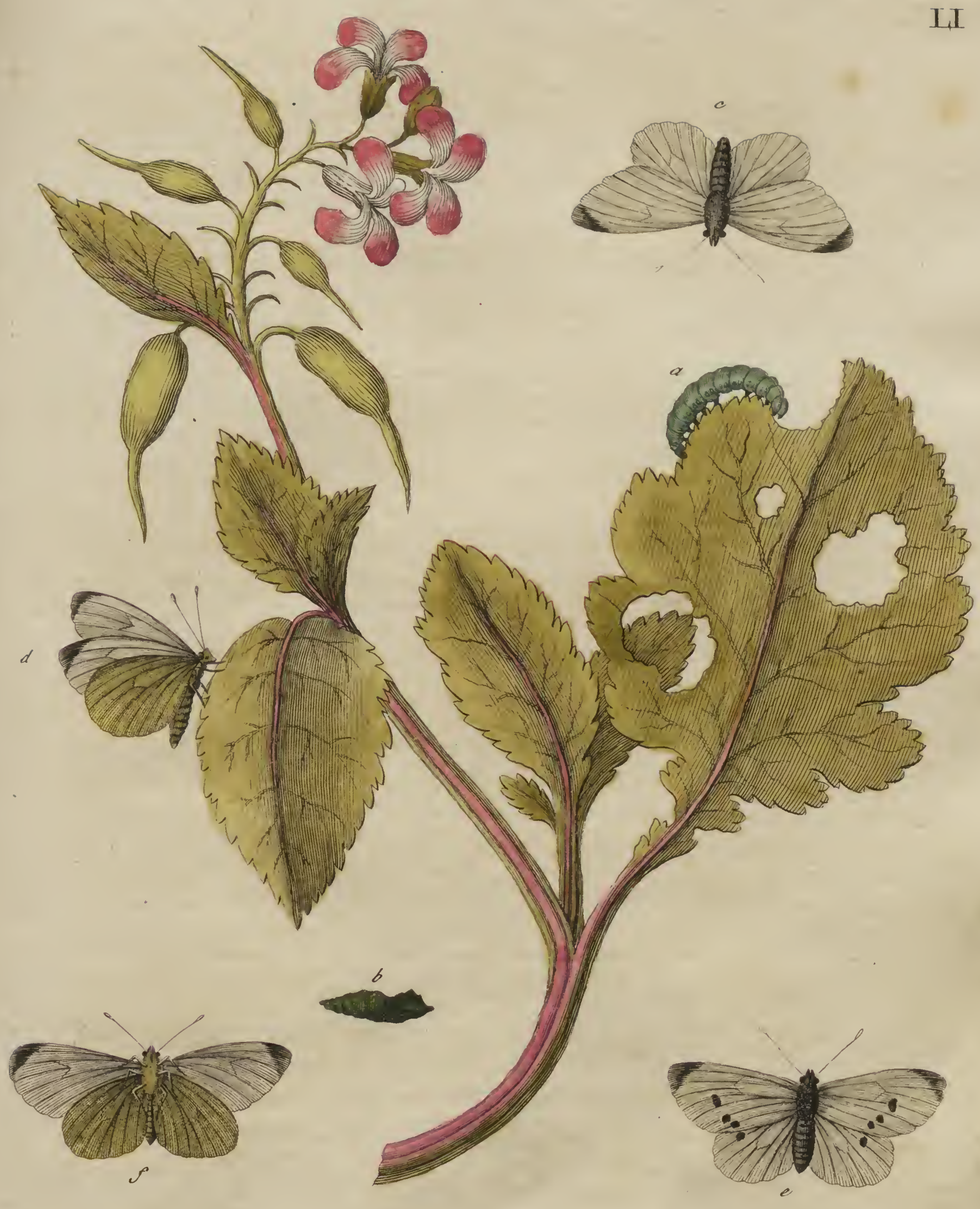

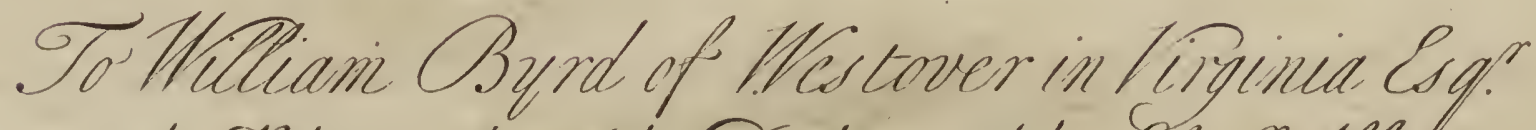

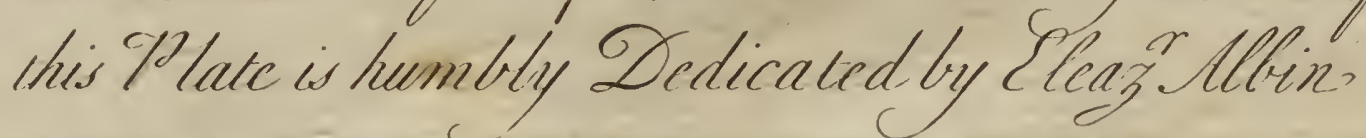




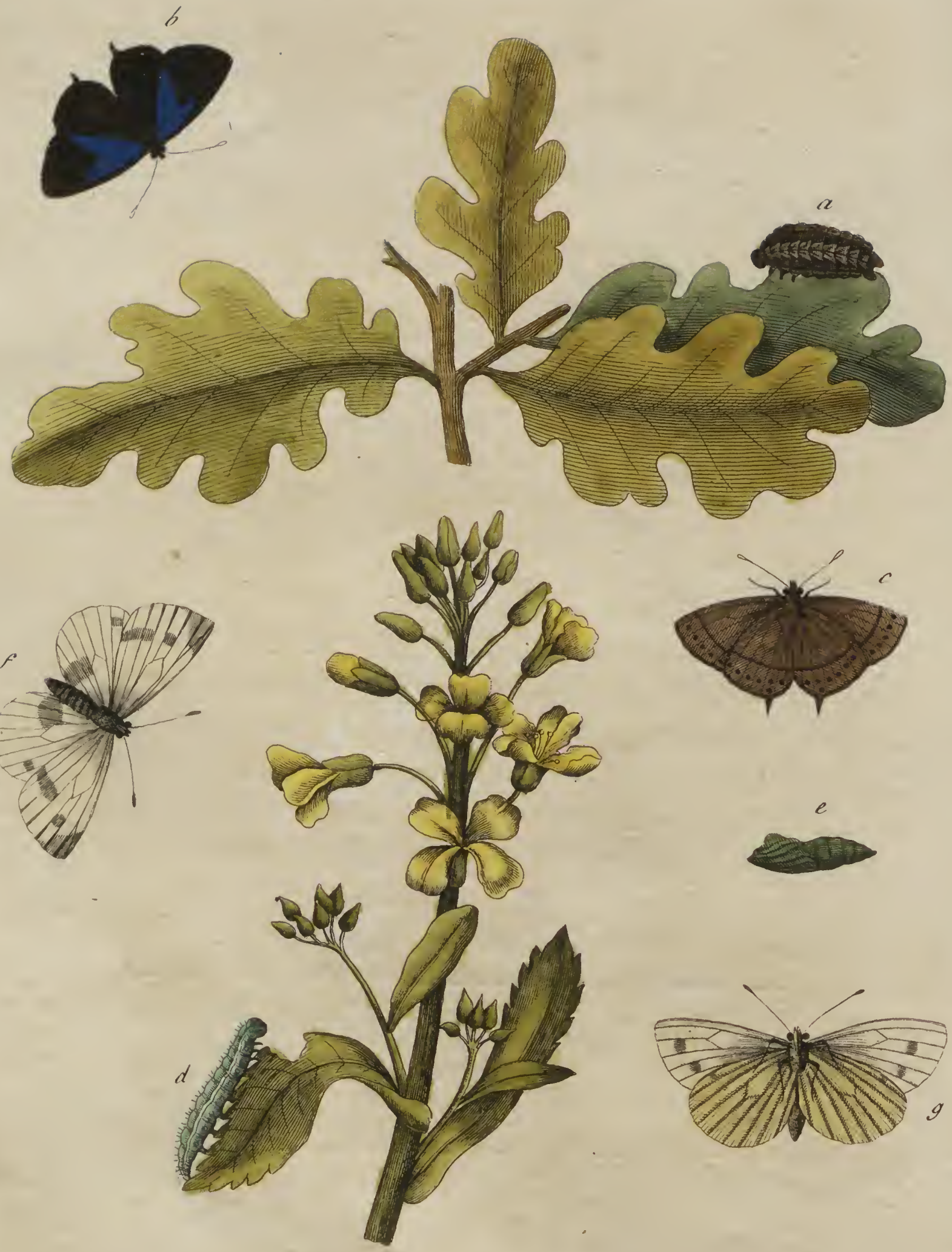

To Tohn Gooks Gsp!

This Plate is humbly dedicated by Cleng.' Allin 


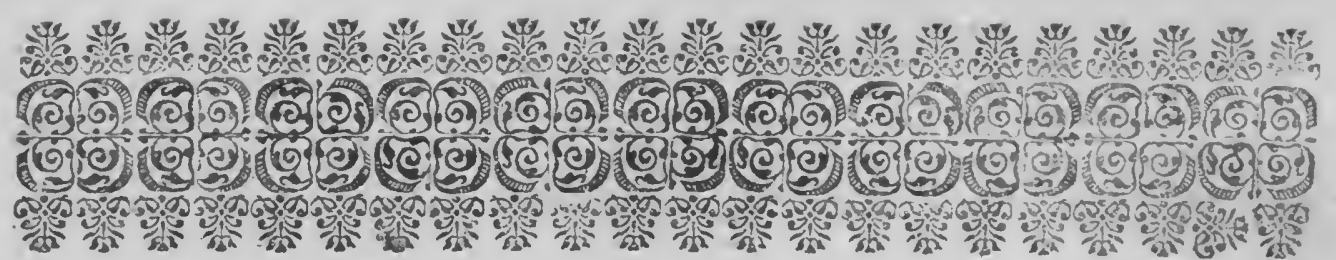

The Description of the Fifty Second PLATE.

DE ftrange-thaped C ATER P I L A R, $a$, 1 in this Table, was Yellow. It was found on the Oak in Cain Wood near Highgate, the I Ith of Fune; and changed into a Chry falis the I 7 th of the fame Montb. On the I 4 th of $F u$ ly came the Butterfly, the upper Side, b, of a dark brown and blueifh Purple, the under Side $c$, of a light Hair Colour, it is commonly called the Purple Hair-ftreak.

The Caterpillar $d$, was Green with a Stripe of Yellow on each Side. It was found on the Cabbage about the latter End of Fune, and the Beginning of $\mathscr{F} u l y$ it tied it felf up and changed into Cbryfalis, e, the 20 th of the fame Month came forth the Green vein'd Butterfly e, f. See Merian, Vol. 2. Chap. 39. 


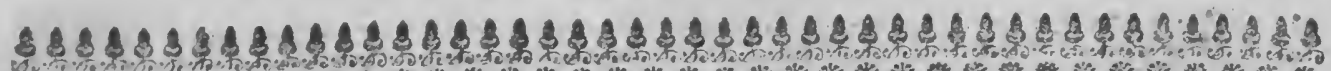

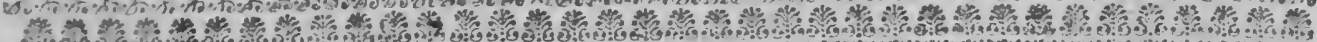

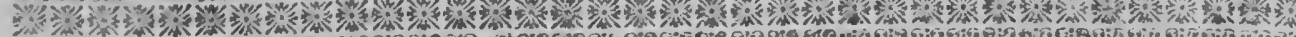

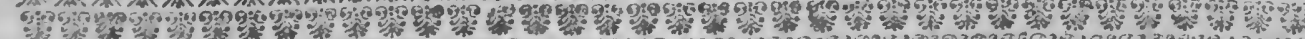

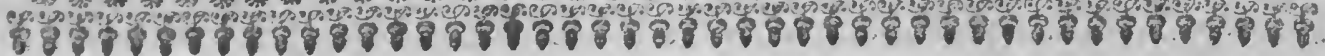

The Description of the Fifty Third PLATE.

THE Caterpillar, a, in this Table, I was Green, and covered all over with fhort Hair. It was found feeding on Grafs the 8th of May, and the 24th of the fame Month it faftnedit felf up by the Tail, and changed into a fhort thick green Cbryfalis ftrcaked with Black, and the I ith of Fune came the Meadow Brown Butterfly: $b, c$, the Male; and $d, e$, the Female; having each an Eye in their upper Wing. 

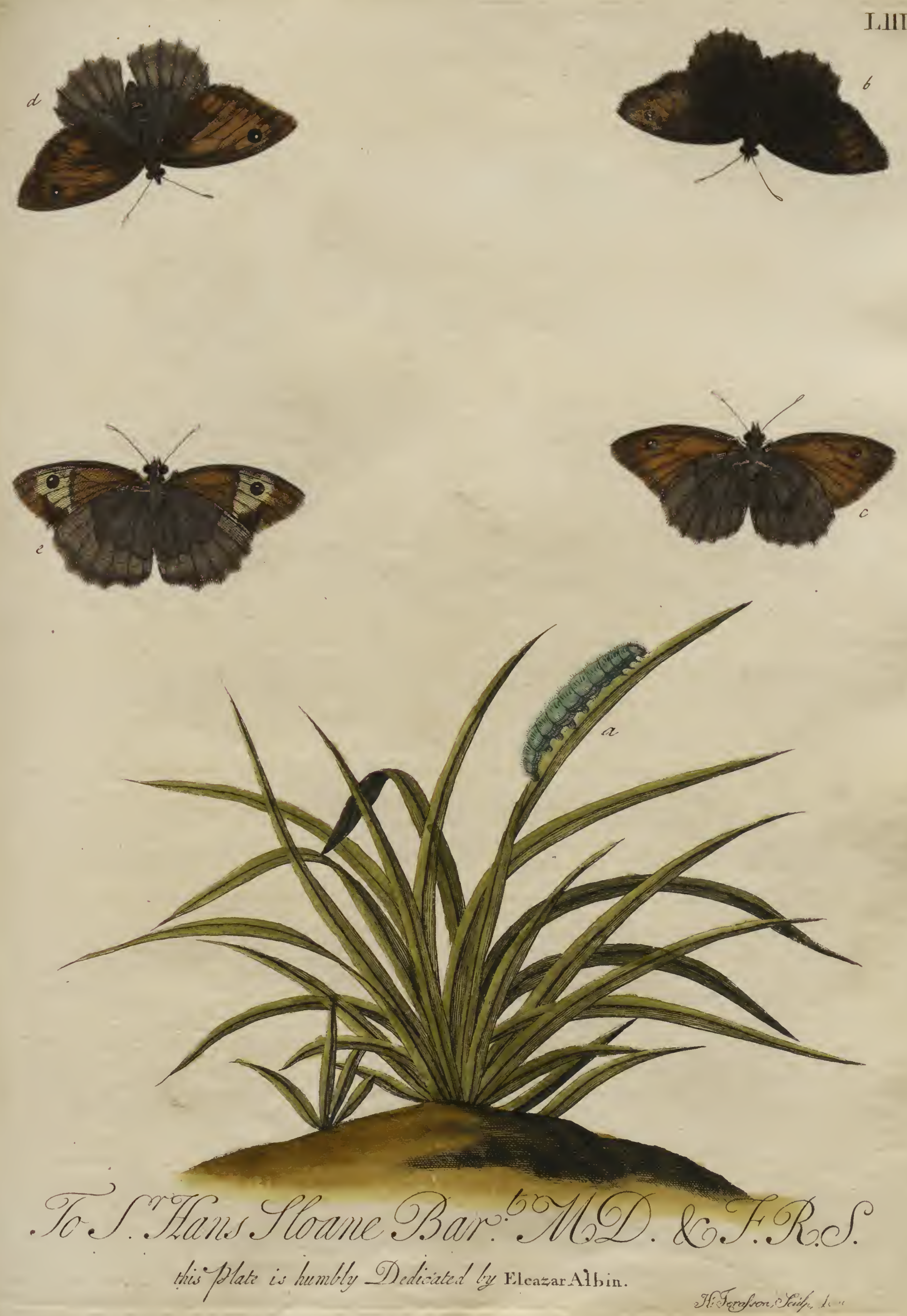


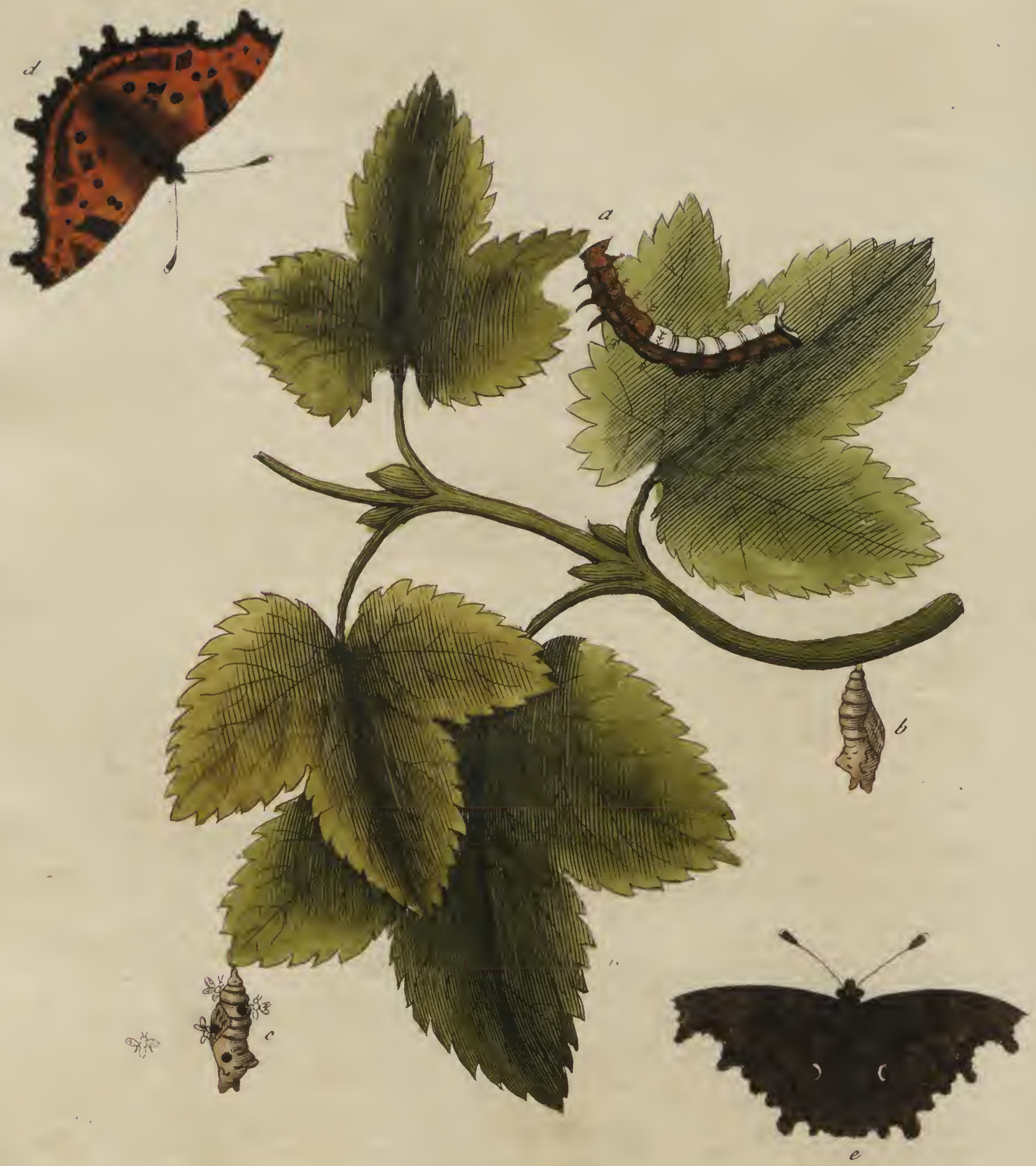

TO THE RT HONOR.ABLE

- Tecomas ford. Trafey

This Plate is humbly dedicated Iny Gleng." tiein. 
The Description of the Fifty Fourth PLA'TE.

$\mathbb{1}_{\text {TERPr:LAR, } a \text {, in this Table were Brown }}^{\text {HE Belly and half the Back of the } \mathrm{C}_{\mathrm{A}} \text {. }}$ fpotted with Red, the other part White, with Brifles of the refpective Colours on each. It was found fee-ing on Hops the 26 th of Fuly; the 7 th of Auguft it changed into Cbryjalis, b, and the $23 \mathrm{~d}$ of the fame Month came a Scalloptwinged Butterfly, $d, e$, of a Brown Orange Colour, having in the Middle of the under Side of each under Wing a white mark like a Comma, from which it is ufually fo call'd. See Merian Vol. I. Chap. I4. 
The Description of the Fifty Fifth PLATE.

THE Caterpillar, $a$, in this Table was 1 blueifh fpotted and brifled with Yellow, the Head and Feet Black. It was taken on the Elm the roth of Fune. The CA TER PIL L ARs when young keep together, and when full fed they ordinarily tie themfelves up by the Tailunder the Coppings of Walls, or fome fuch fhelter, and change into Cbryfalis, $b$, which is about the middle of Fune; and in the beginning of Fuly produce a Butterfly $c, d$, commonly called the great Tortoife-Sbell. From feveral of thefe Chryfalies came Broods of fmall Icbneumon Flies expreffed near the Chryfalies. See Liffer on Godart page 3. $\mathrm{N}^{-0}$ 3. See Merian, Vol. 2. 7ab.2. 

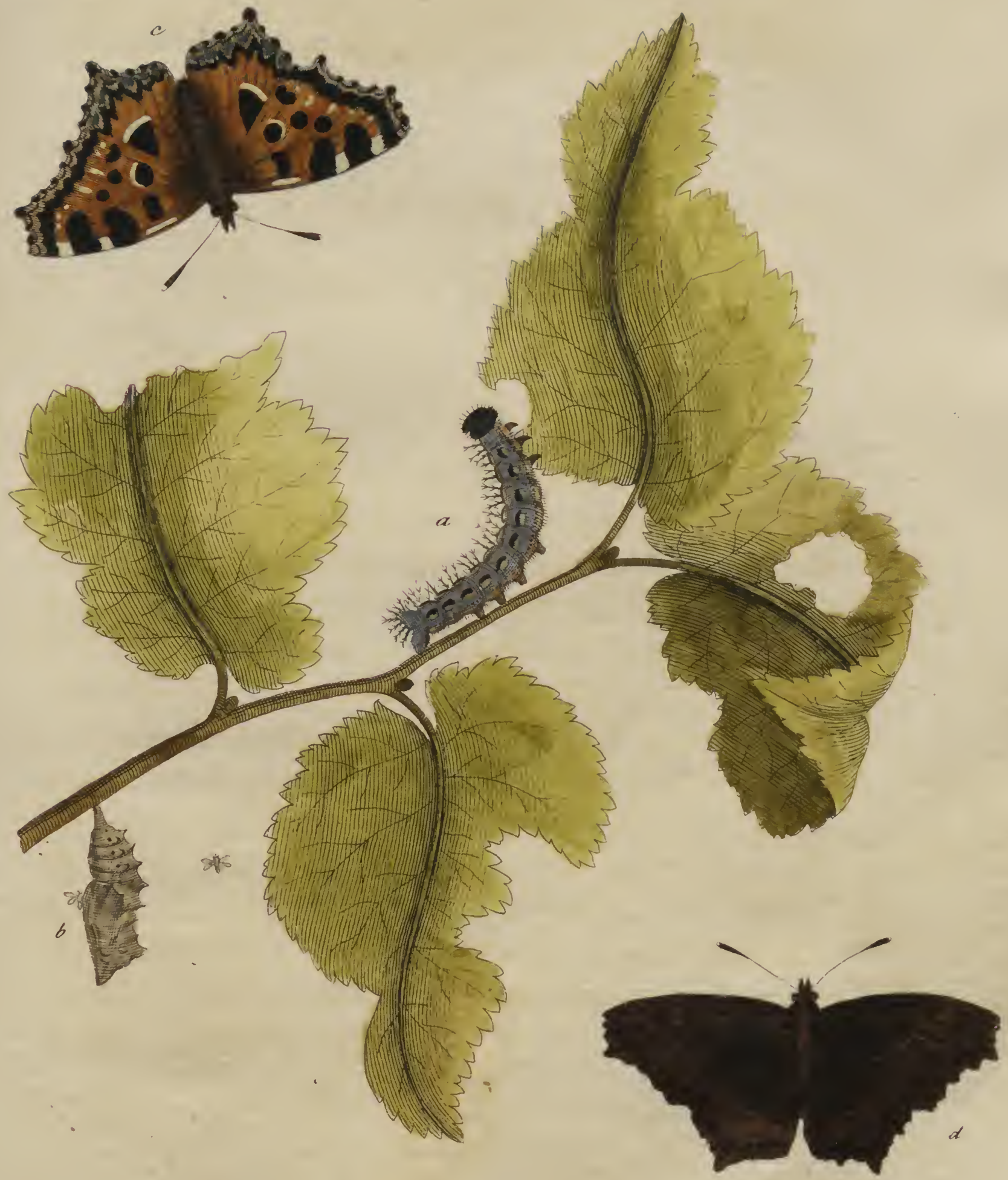

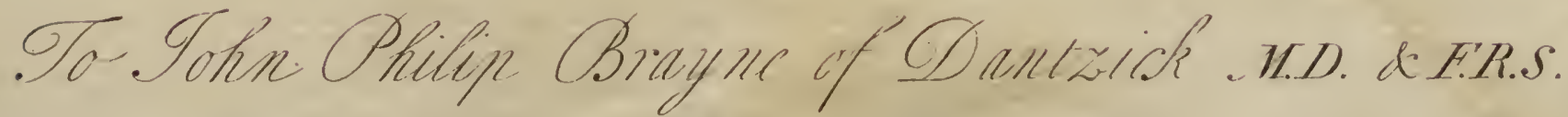
This Plave is humbly dediated by Bleaz. Albin. 
LVI

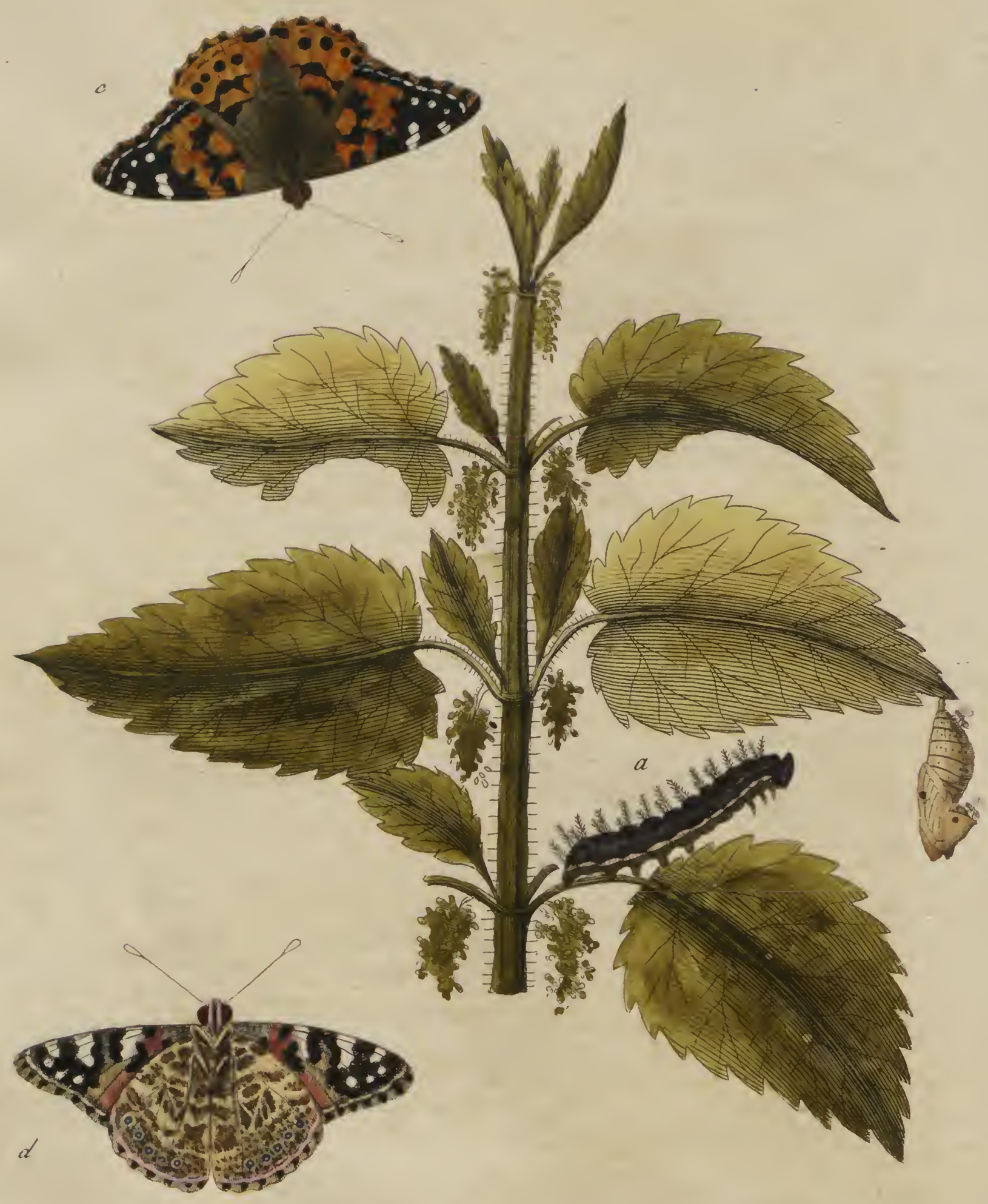

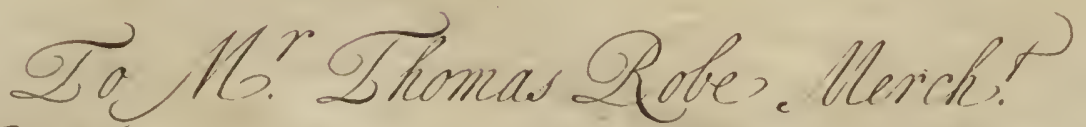

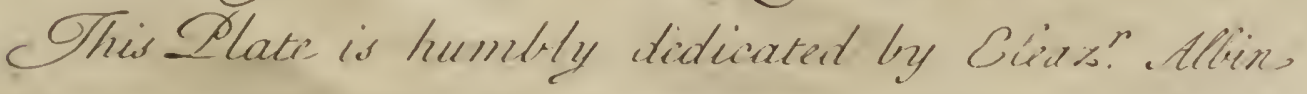


The Description of the Fifty Sixtb PL a TE.

\section{ThE Caterpillar, $a$, of 1 this Table is moft commonly} Black, and fometimes Yellow, much like the CaterpiLLars of the third Table, and is not eafily diftin. guilhed from them; this feem'd to me fomewhat flender. It was found fpun up in the Leaves of the large Nettle, the 22d of Fune; at the latter end of the fame Month, it changed into Cbryjalis, and the 15 th of Fuly came a moft Beautiful Butterfly, c, d, called the Painted Lady. See Liffer on Godart, page 7. $N^{\circ} 5$. 
The Description of the Fifty Seventh Plat E.

T HECaterpillar in this Table was 1 Green, and friped with White, the laft of which went up into the Horn on his Tail. It was taken feeding on the Poplar at the Beginning of September, and at the latter End of the fame Month it went into the Ground and changed into a Cbryfalis, and remained in that State till the Beginning of May, at which time came forth the Moth, $c, d$, the CATERPILL A RS with Tails produce Motbs that are very fwift of Flight, for which Reafon they have the Name of Harwk Motbs. this being commonly called the Poplar Hawk Moth; 


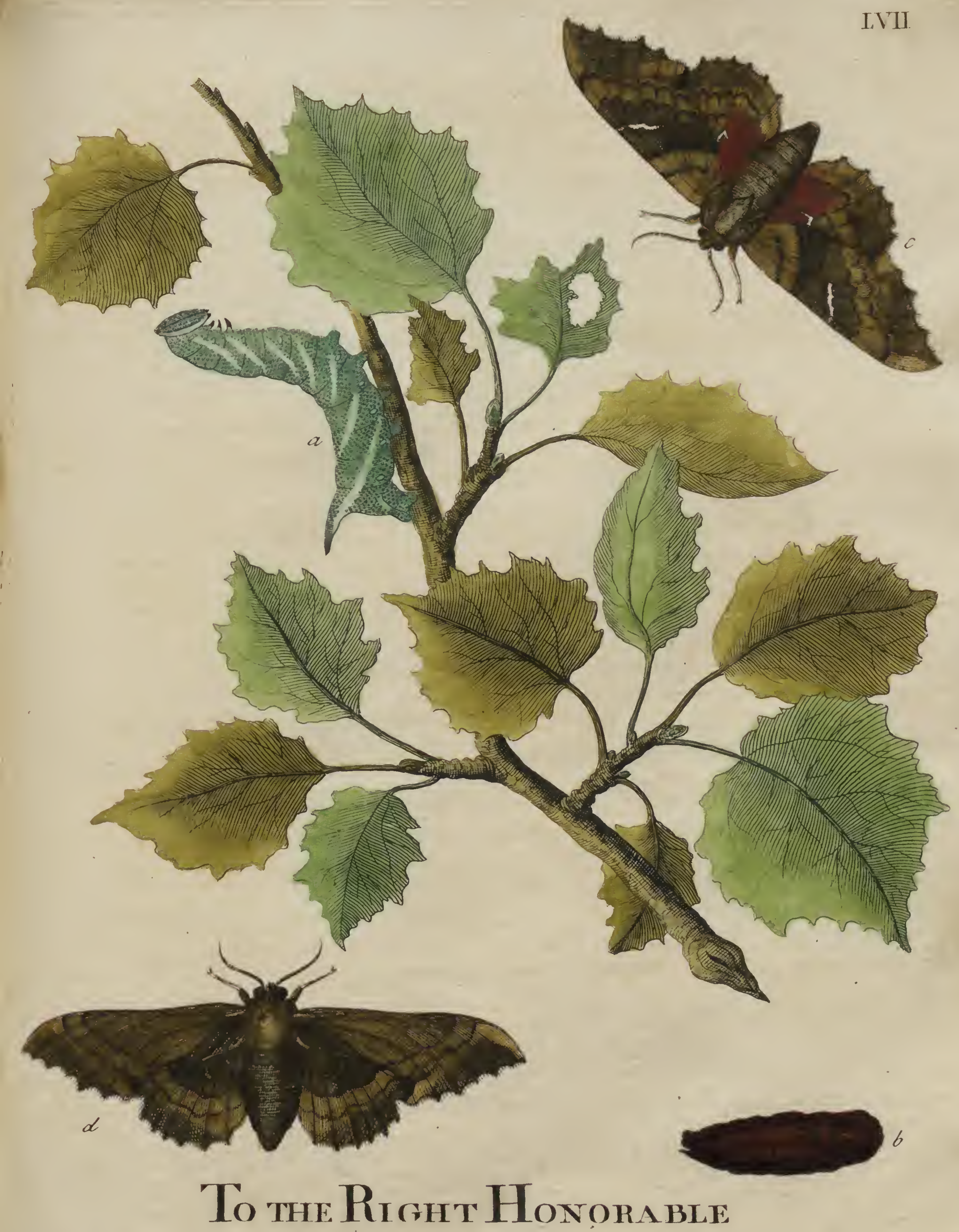




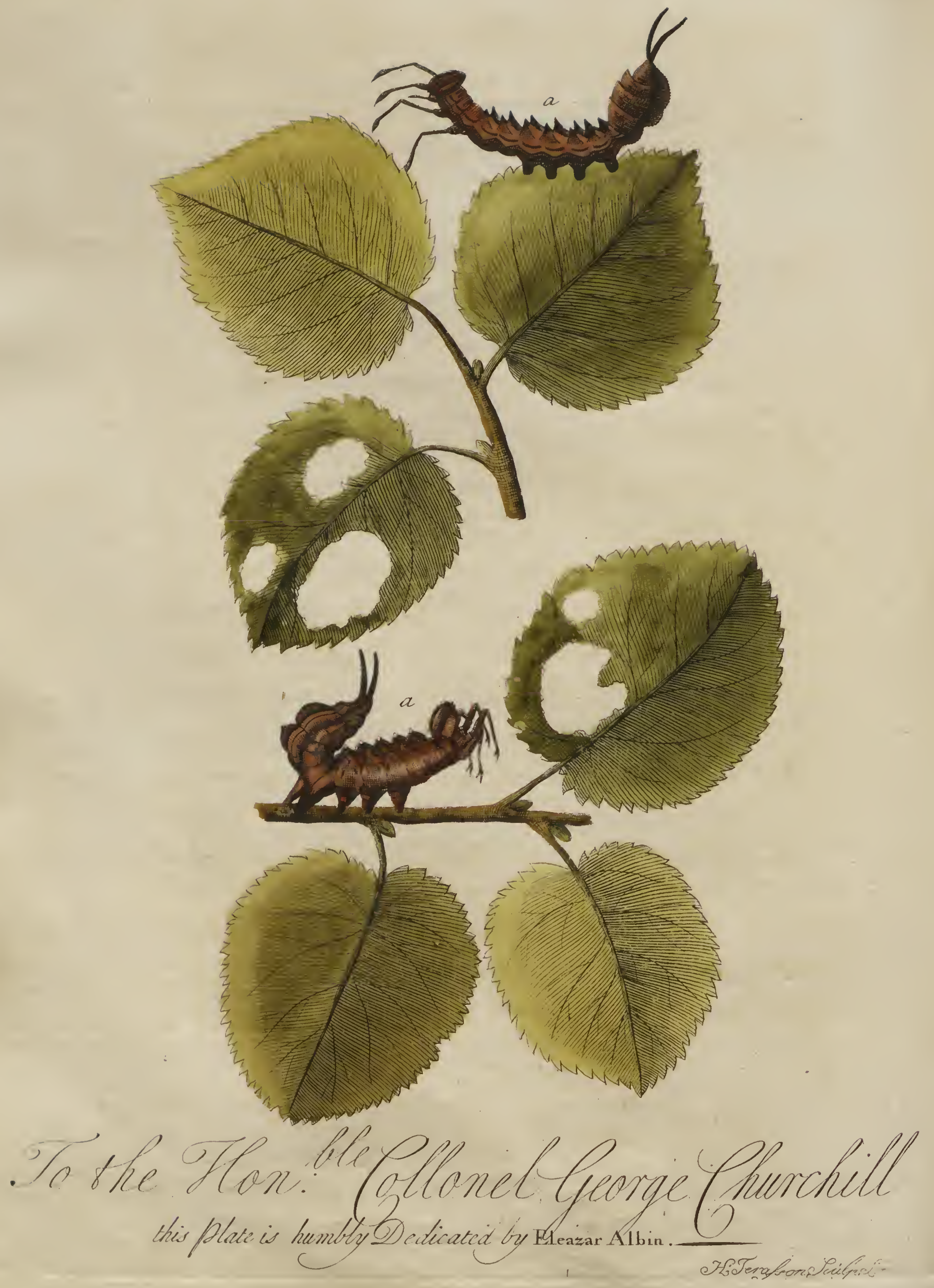


FEo

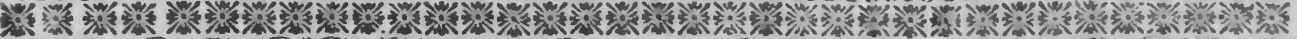

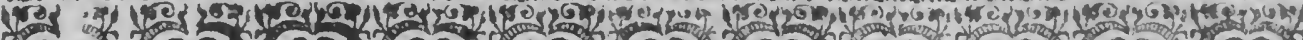

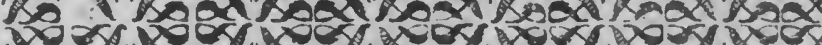

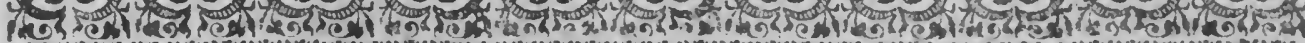

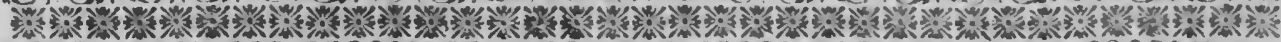
Fos.

The DESCRIPTION of the Fifty

$$
\text { Eighth PLA TE. }
$$

THis Caterpillar was taken on 1 the Hafle in Norwood near Dulwitch the 9th of Auguft, it was of a brownith Orange Colour: I have drawn it both in its moving and ftanding Pofture, the better to exprefs its odd Shape and Manner from its Look which has fome Refemblance of a Cruftaceous Fijh, for which Reafon I have given it the name of the Lobfer CATER PILlaR. It was kept in a Box with fome of the Branches of the Halle fet in Bottles with Earth under them to facilitate its Change; but I did not perceive it to eat. It fpun it felf up the $13^{\text {th }}$ of the fame Month between the Bottles in a tranfparent Cafe, and dyed without changing. 
The Description of the Fifty Ninth PL A TE.

\section{T}

HE Caterpillar, $a, a$, in this Table was Yellow, with a Shade of Green on its Sides, a blueith Stripe on its Back edged with fmall Lines of Black, and over all its Body fmall white Specks, it had two black Spots reprefenting Eyes in the upper Part of its Head. It had three Feet and eight Holders on each Side, which I have obferved in moft of the CATERPILLARS of the Icbneumon Kind. Their manner in Standing is different from other CA TERPILLARS, for they generally curl their Tails. This was found on the Dutch Willow the $2 \mathrm{~d}$ of Fuly, and the roth they fun a Cylindrical Jbining Case, b, and the 25 th of May came the $F l y, c$.

The two Caterpillars on the upper Part of the Branch, $d, g$, were taken at the Beginning of $\mathcal{F} u l y$; the 8 th of the fame Month they went into the Earth, and made a Cafe, e, like the former; about the middle of Anguft the $\mathrm{C}_{\mathrm{A}}$ TERPILlar, $d$, produced the $F / y, f$, and the CaterpilI AR, $g$, that at $b$. 


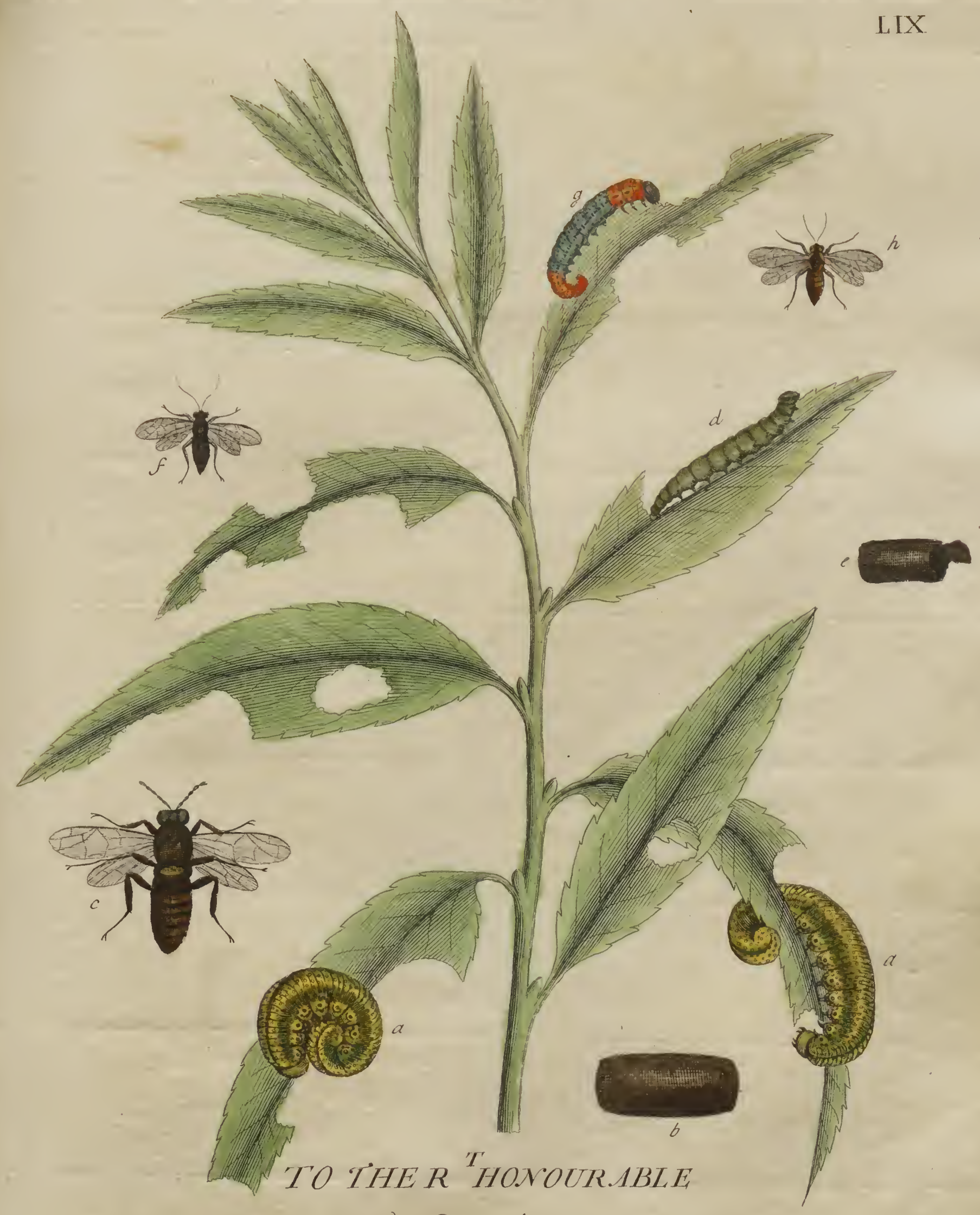

\section{The Lord. Tlay}

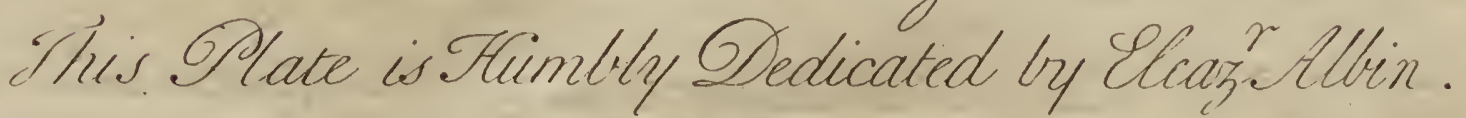



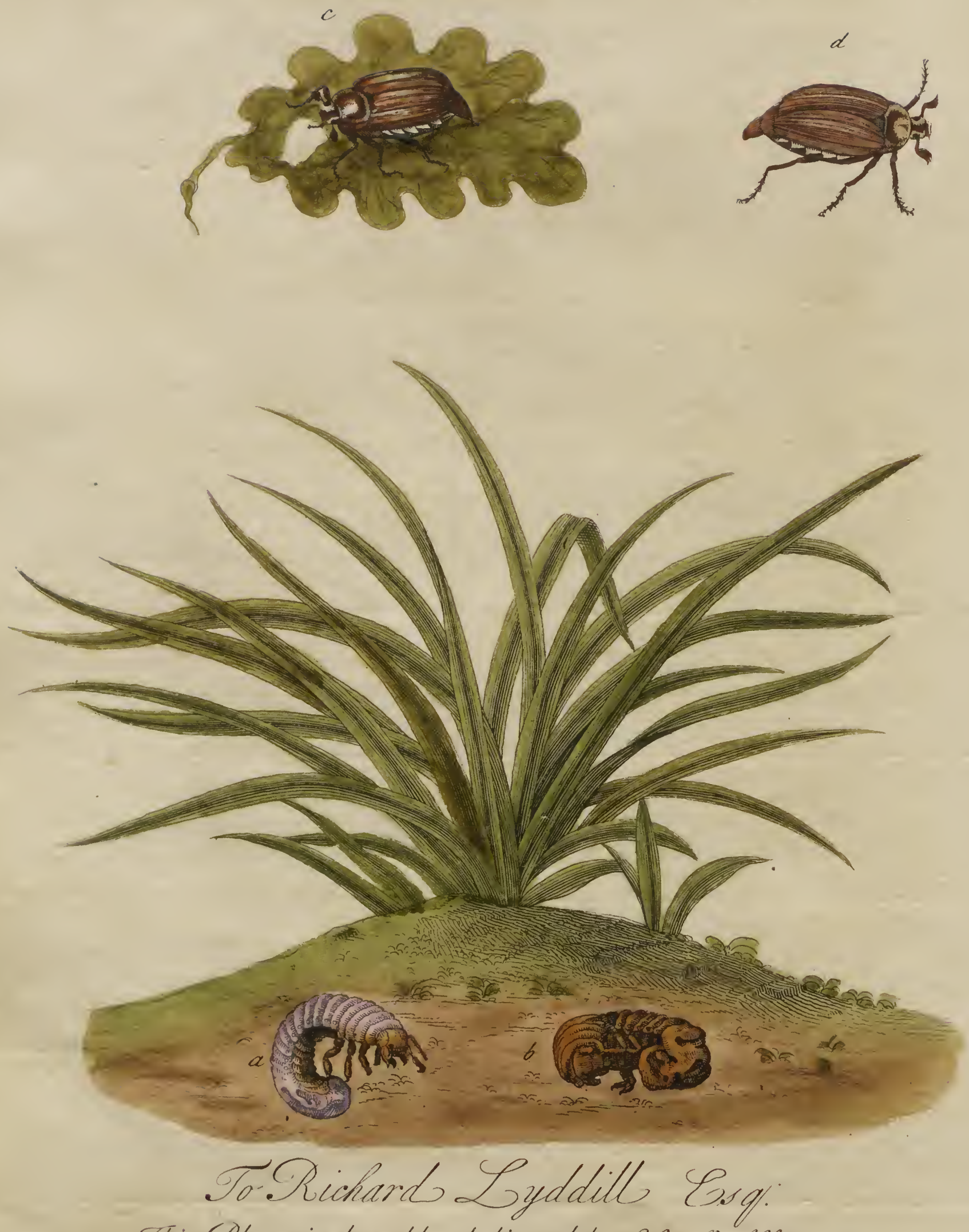

This cylue is humbly idedicatid by Gleuz?. Atrien. 


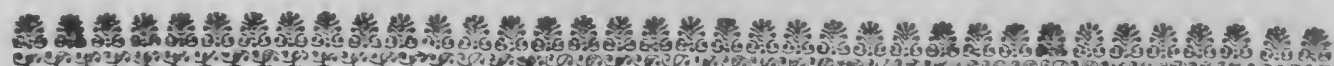

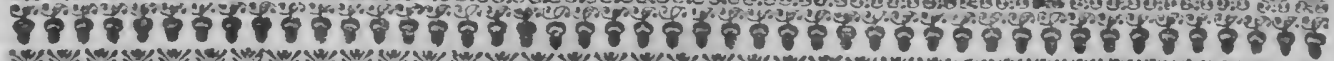

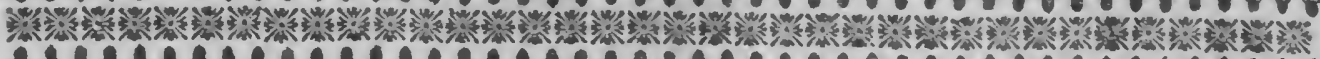

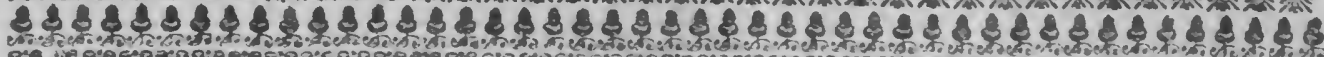
唯

The Description of the Sixtieth PLATE.

THE Grub or Worm in this Table, at as

1 is commonly found in Grafs-fields which are new ploughed. I found many of them by following the Plough. I obferved that the Crows and Rooks. were very diligent in picking them up. I put feveral of them into a Box, in which they killed one another with their Nippers; thofe which remained I kept in a Pot of Earth with fome of the Roots of Grafs and other Plants. They changed into Chryfalis, $b$, about the Beginning of September, and in the middle of May came forth a brown Beetle called the Chafer, Oak Web, or May Beetle, the Male at $d$, and the Female at $c$, 


\section{The Description of the Sixty Firft Pla'T E.}

THEGrub on the green Leaf, at $a$, was purple and Yellow. It was found on the Orach the 25 th of Fune: feeding on fmall Infects, which were very numerous on that Plant. With thefe I fed them till they compored themfelves for Change, which they did the 27 th of $f u n e$, by faftning their Tails to the Leaves of the Plant, and chaned into Cbryfalis, $b$; from thefe came the red Beetle fpotted with Black, called the Cow-lady, $c$, , the uppermoft of which hath its Wings expanded, See Liffer on Goddart page I08. $N$ I I 2 .

The dark colcur'd Grib under the Grafs at $d$, was found in the Earth the 25 th of April. I fed it on the Roots of Grafs in a Pot till the 2oth of Auguft. It then changed into a Cbryfalis, e. I had two one of them was kept moift, and produced a Fly called the Harry long Legs or Taylor Fly, this prov'd a Female, g, and laid four hundred Eggs in a Box l kept her in; the other was kept dry, and it thrunk up and died. I have often obferved that keeping Cbryfalies too dry is a great Hindrance of their perfecting the $F / y$. The Male is expreffed at $f$. See Lifter on Goddart, page 33. No 139 . 

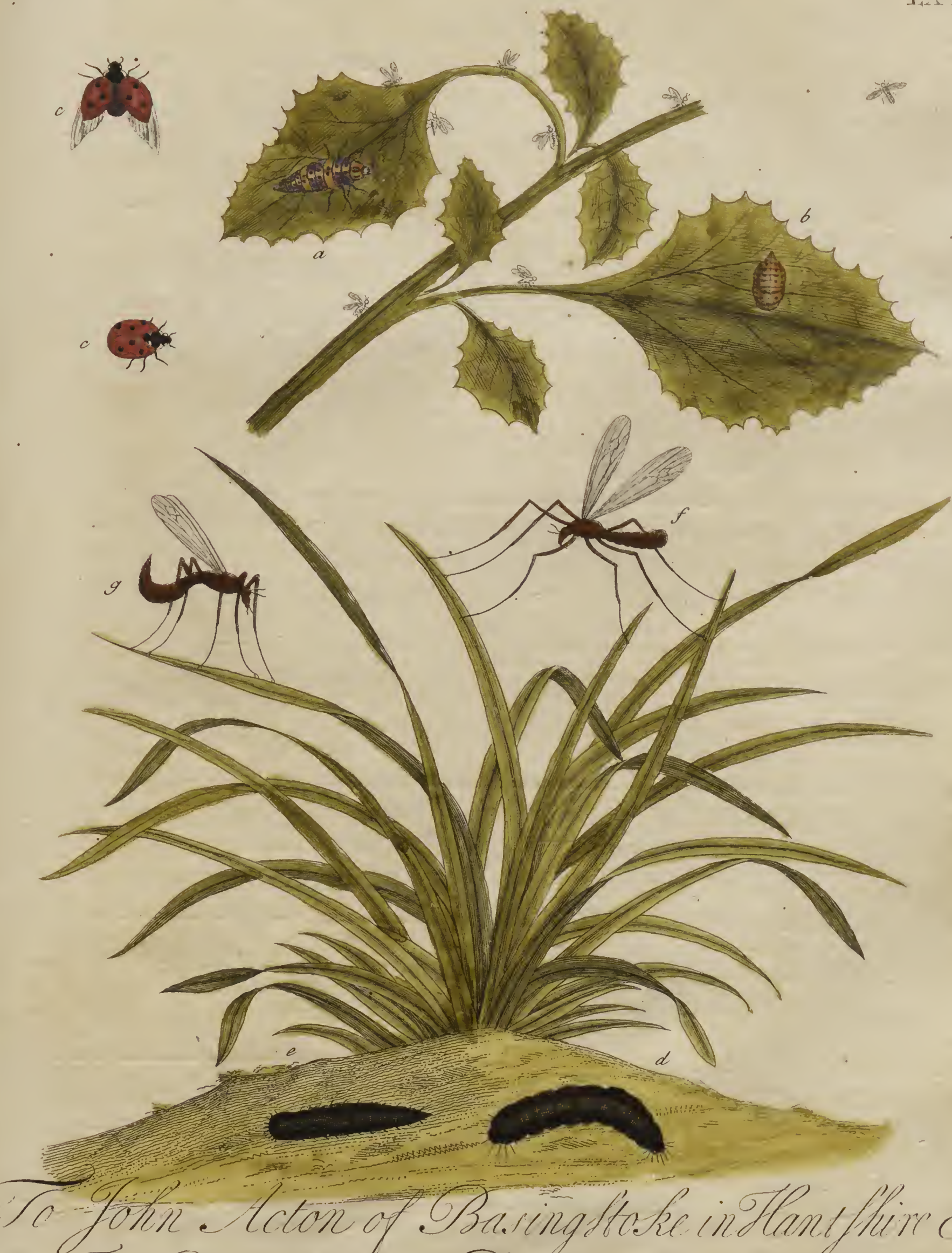


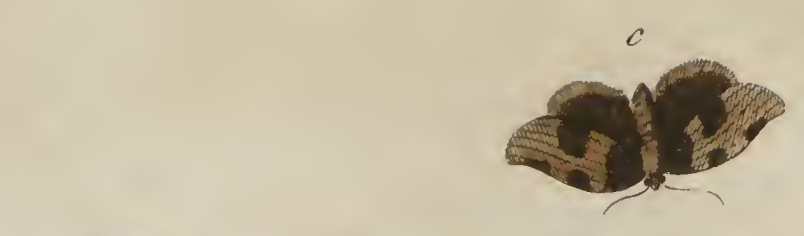

L.XII.
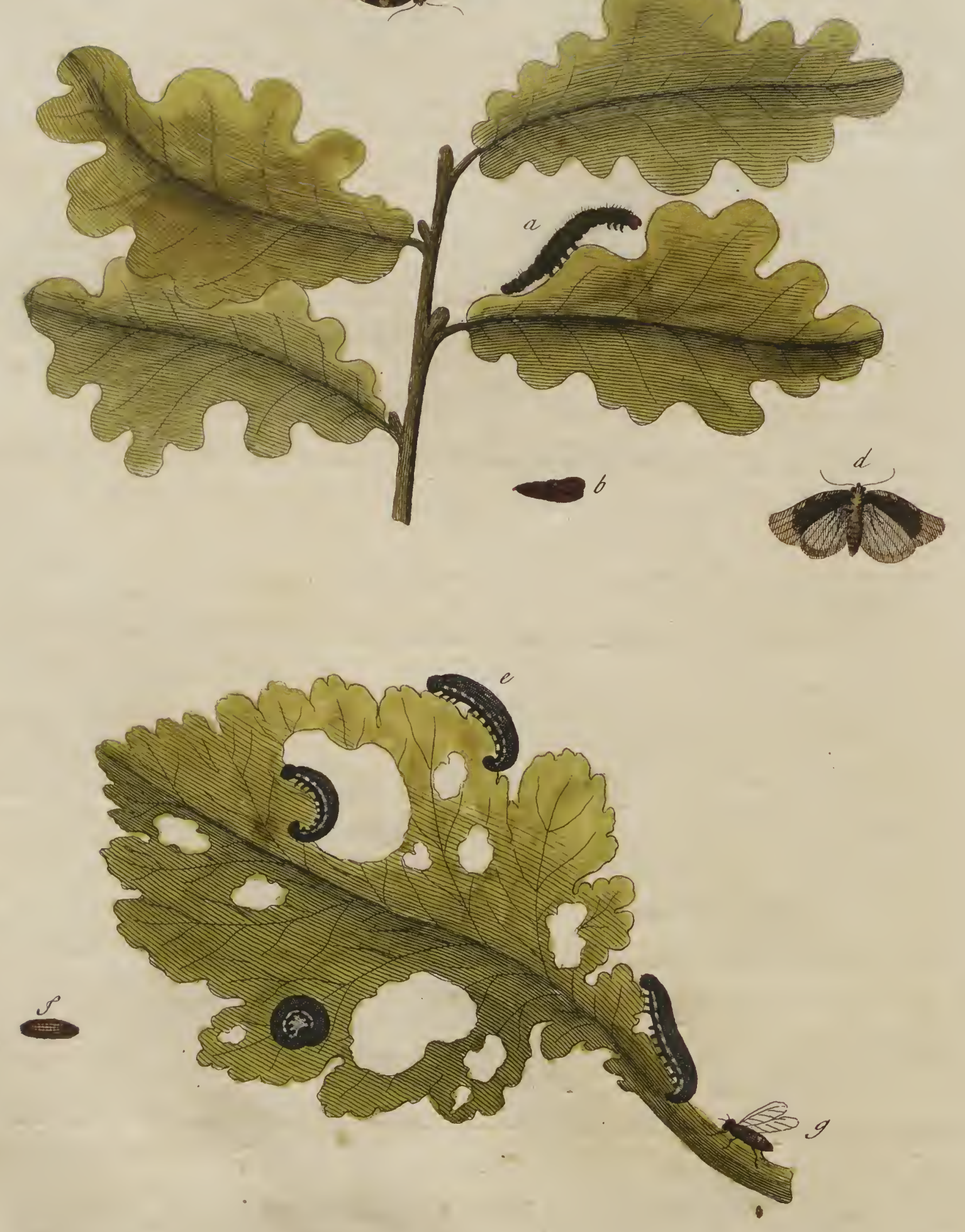

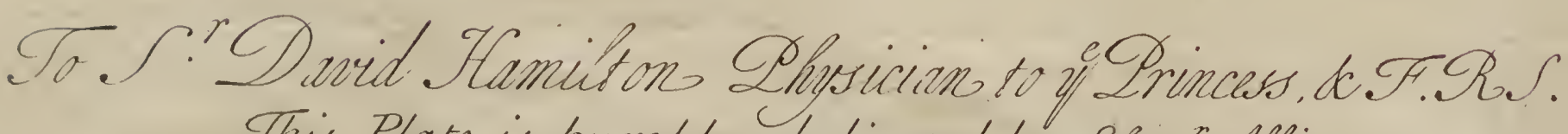
This Plate is humbly dedicated by Gleaz. Albin 
The Description of the Sixty Second PL A T E.

THE Caterpillar, a, in this Table, 1 was of a muddy Green fpotted with White. It was found feeding on an Oak in Cain Wood the 27th of May; it fpun up on the 3 oth of the fame Month, and changed into a Cbryfalis, $b$, and the 22d of Fune came the Moth of an Olive Colour fpotted with Brown, $c, d$.

Thefe black Caterpiluars of the $I c b$ neumon Kind, $e$, were found feeding on the Turnip Leaves in the Beginning of September 1719, they being fo numerous at that time about London, that they deftroyed whole Fields of them: about the latter end of Septeniber they went into the Earth and fpun themfelves up in a tranfparent Cafe, and changed into a Chryfalis; and in Moy following came forth a fmall Ichneumon Fly, figured in the Table at $g$. 
The DESCRIPTION of the Sixty Third Plate.

$T$ HE yellowifh Grub, a, on the Leaf was I fpotted with Black. It was found on the Dutch Willow about the 2oth of Fune, and changed into Chryfalis, $b$, the next Day; and the $5^{\text {th }}$ of Fuly came a large red Beetle, $c$, which lays Eggs of a Cream Colour longih and ftanding upright on the Leaf, $d$.

The Maggot, $e$, is commonly found in Privies and corrupt Water of Sinks. I obferv'd it to have fourteen fmall Protuberances on the Belly like Feet, by which it climbs up into a Refting-place when fit for Change; I believe it makes ufe of its long Tail in guiding it felf in the Water. It changed into Cbryjalis, $f$; about the latter End of Auguft, and remained juft fifteen Days in that State, before the Fly, $g$, came forth, which repretents one of the Bee Kind. 


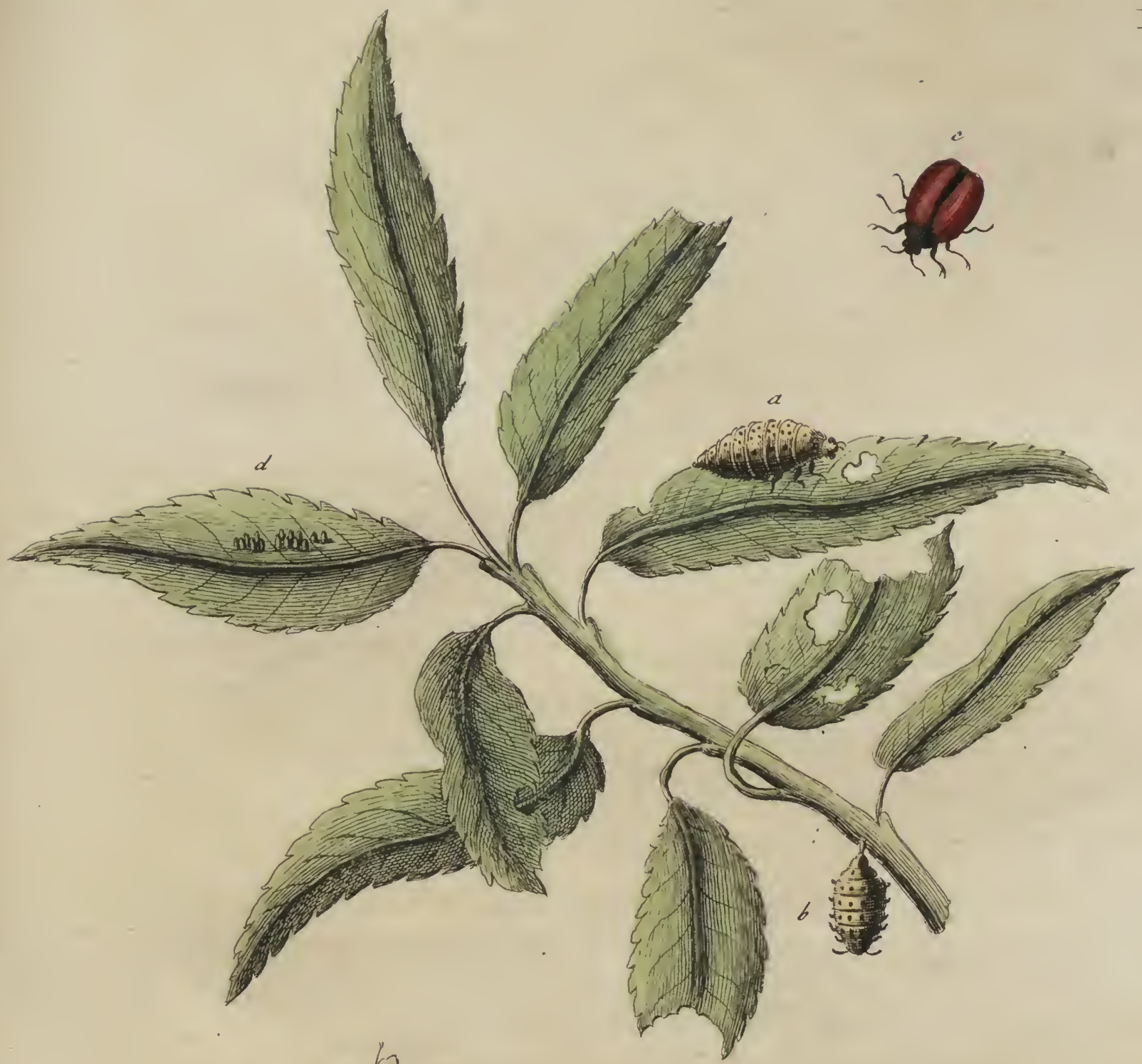

LXIII

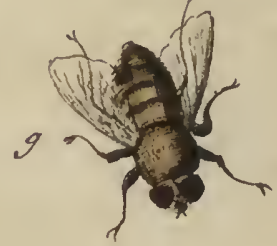

S

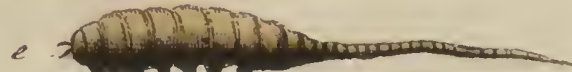

Te the. Fonourable. Mrs Thenne

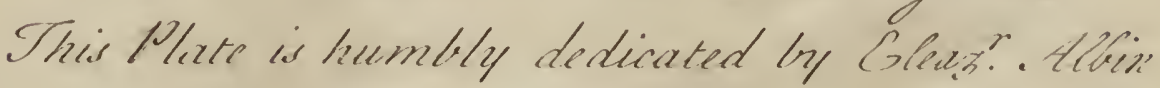




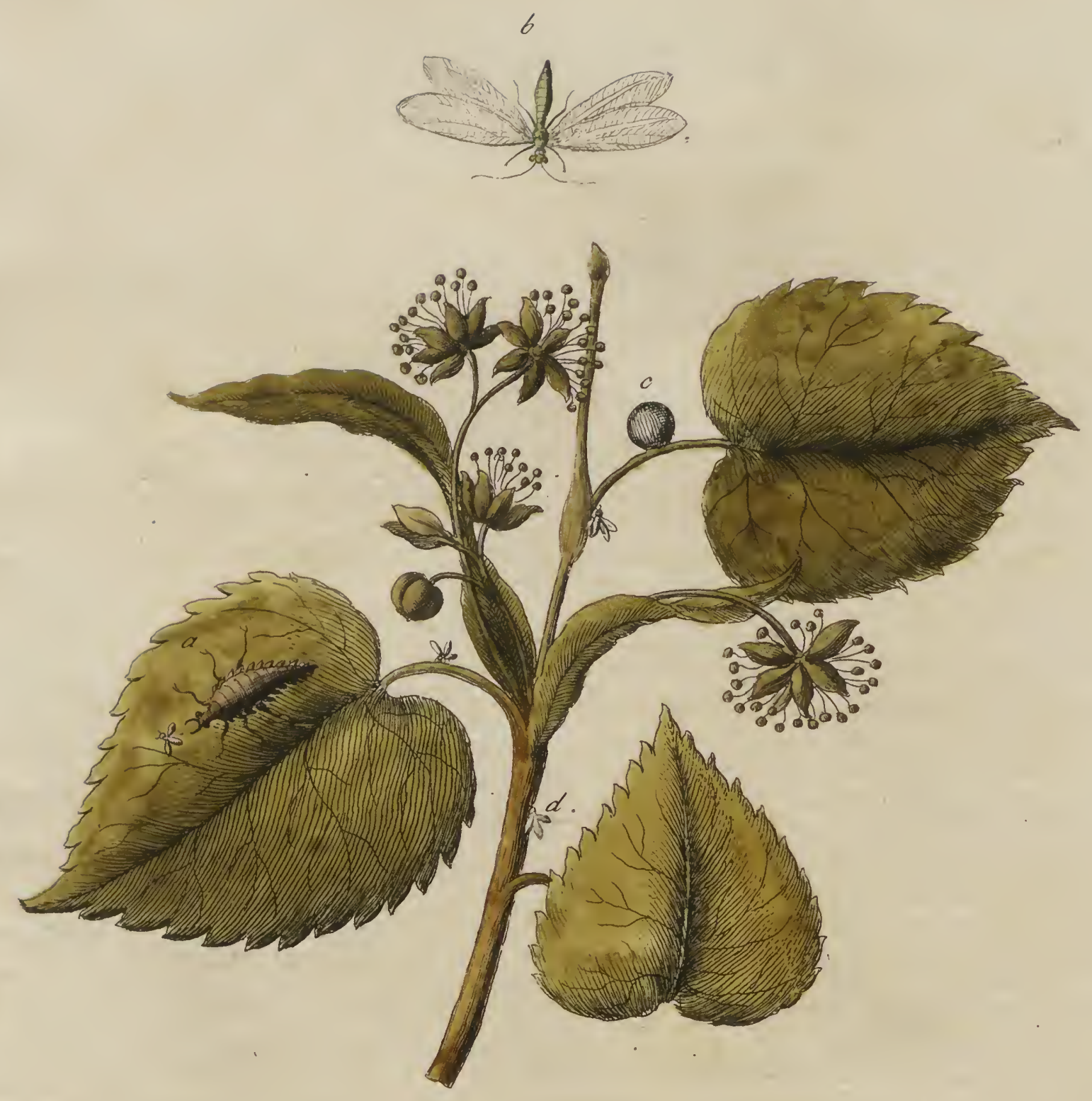

\section{Tolice. Chamberlain Coos}

This Plave is humbly dedicated by Gleasy. . Plain 
The Description of the Sixty Fourth PL A TE.

THE Hexapode Worm on the Leaf, at $a_{3}$ 1 was brownifh. It was found on the LimeTrees at the latter End of Fuly, and fed on fmall Flies in the fame Manner of the Worm, a, of the fixty firft Iable; on the fecond of Augufl it fpun it felf up in a white Silken Cafe like that of a Spider's Egg, and the r 6 th of May following came the Green-Golden-ey'd Fly; it having the moft beautiful Eye of any Infect that I have yet feen. His Wings are very remarkable for their Tranfparency and bright Colouring in them like that of a Rainbow, and when viewed with the Microfcope, the Edges and every Divifion of the Wings are befet with long Hairs. I have obferved in the Woods two Kinds more of them, the one of a dark Purple, and the $\mathrm{O}-$ ther of a blueifh Green. See Lifter on Godart page 93. $N^{\circ}$ 104. 
The Description of the Sixty Fifth PLA TE.

He Caterpillar, $a$, was Flefh co1 loured, having a large Gibbofity on its Back. It was found near Hornjey Wood on the wild Rofe, and another of the fame kind on the Oak. They fpun themfelves up in the Leaves folded together with a wbite $W e b$, and changed into Cbryfalis, $b$, and about the middle of May came a Moth exprefs'd at $c, d$.

The Cateirpillar, $e$, was of a dark Red, and had a Gibbofity on its Back like the former. It was found on the Black Thorn the 3d of September, and the 8th of the fame Montbit fpun it felf up in a Copper-colour'd $W e b$; the Moth, $g, b$, came the $3 \mathrm{~d}$ of March. I had others of them that did not come till the middle of May. 


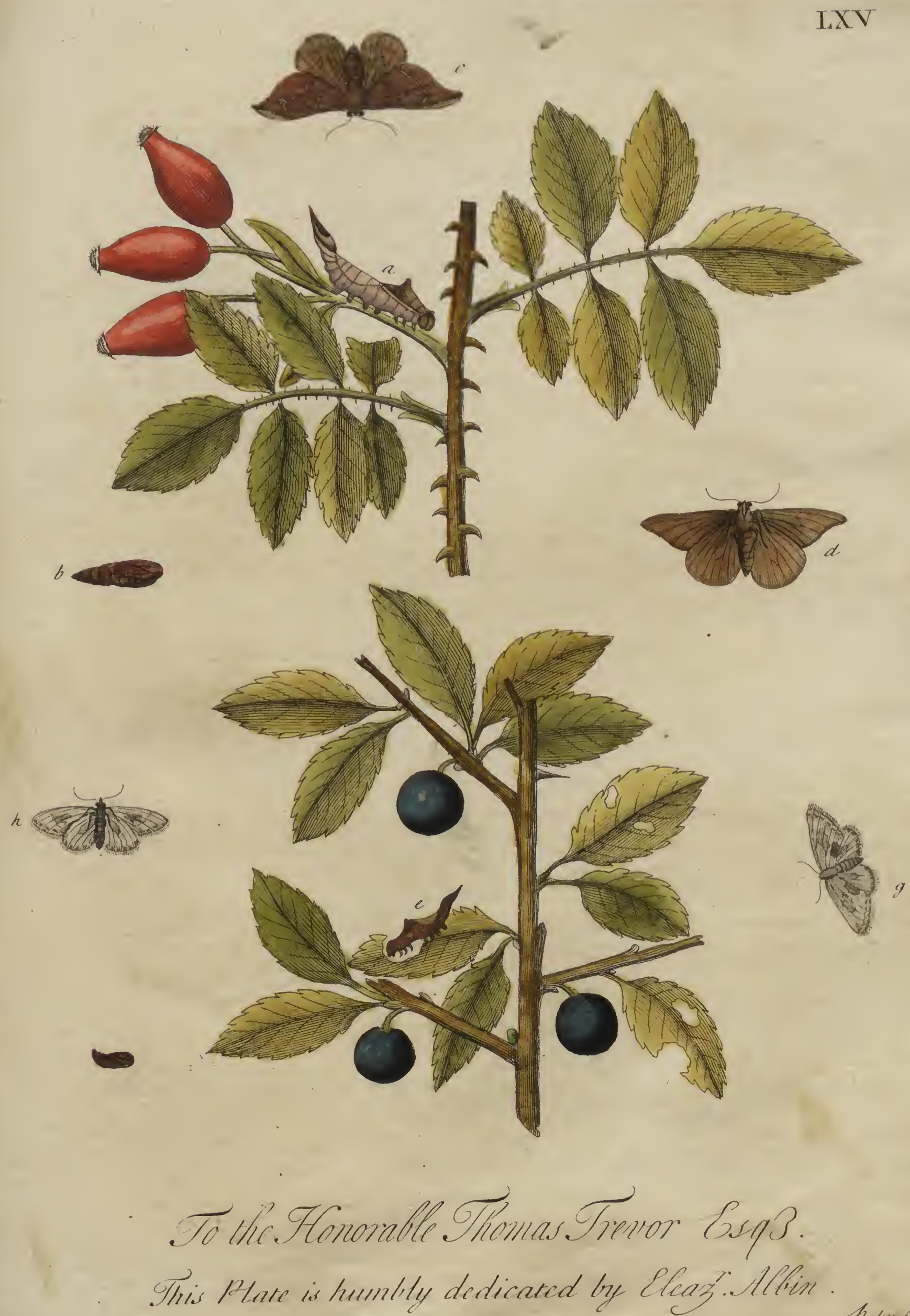




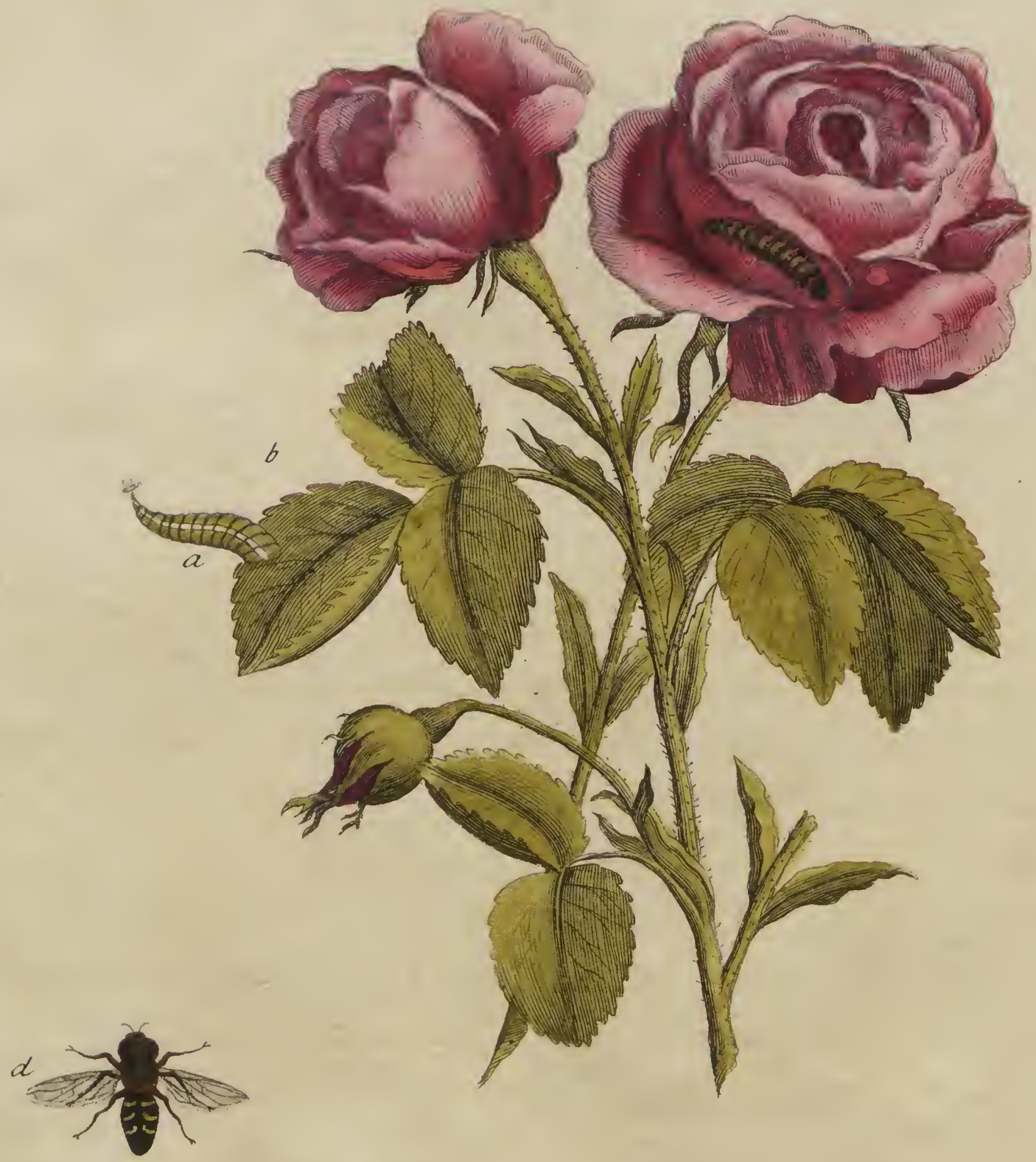

c

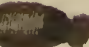

TO THE R HONOURABLE

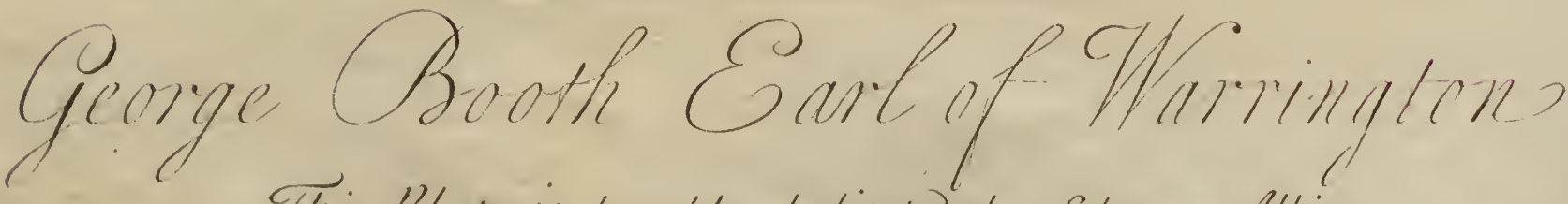

This Plate is humbly dediated by slcazar Mllin. 
The Description of the Sixty Sixth Plate.

T HIS Maggot, a, on the Leaf, was Green 1 with a Stripe of White on its Back. It was found on the Rofe Tree feeding on fmall Infects which live in the Froth that is found on that and divers other Plants; its way of feeding is thus, it having no Feet it faftens it felf to the Leaf by the Tail, which is broad and flat like that of a Leach, and feizes its Prey with its Probofces, then lifting up its Head fucks them till there is nothing left but their Skins. It changed into Chryfalis, $c$, the $22 \mathrm{~d}$ of Fune, and the Fiy, $d$, came the Ioth of Fuly. The Fly of thefe Maggots feems to be apprehenfive of the Want of Feet in the young Embryo, and lays her Eggs near the Place where the Flics are thickeft on the Plants. 
The Description of the Sixty Seventh PL a TE.

THE Caterpillar, $a$, in this Table 1 was Green. It was found on the RofeBay Willow Herb the 3 oth of Fuly, and the 4th of Auguft it went into the Ground and changed into a Chry falis, $b$, and the 16 th of Fanuary came the Moth, $c, d$; from one of thefe $\mathrm{CA}_{\mathrm{A} \text { - }}$ TERPILLARS came the Icbneumon, $f$.

The Cater PILLARs at $g$, were Orange Colour, their Heads black with a Spot of the fame on the firft Foint. I believe them to be of the Ichneumon Kind having more Holders than the common CATERPILLARS. I found them the roth of Fune on a White-thorn near Peckbam; they eat in their $W e b$, fpinning it further as they want Food. They went into the Ground the 2 oth of the fame Month, but could not be hatched with all the Care I could take. I found fome of the fame 2 Years after on a Pcar Tree, and tryed to preferve them by putting them in a Bottle in a hole in the Ground to keep them moift, but a Flood of Water coming drowned all my Hopes. 


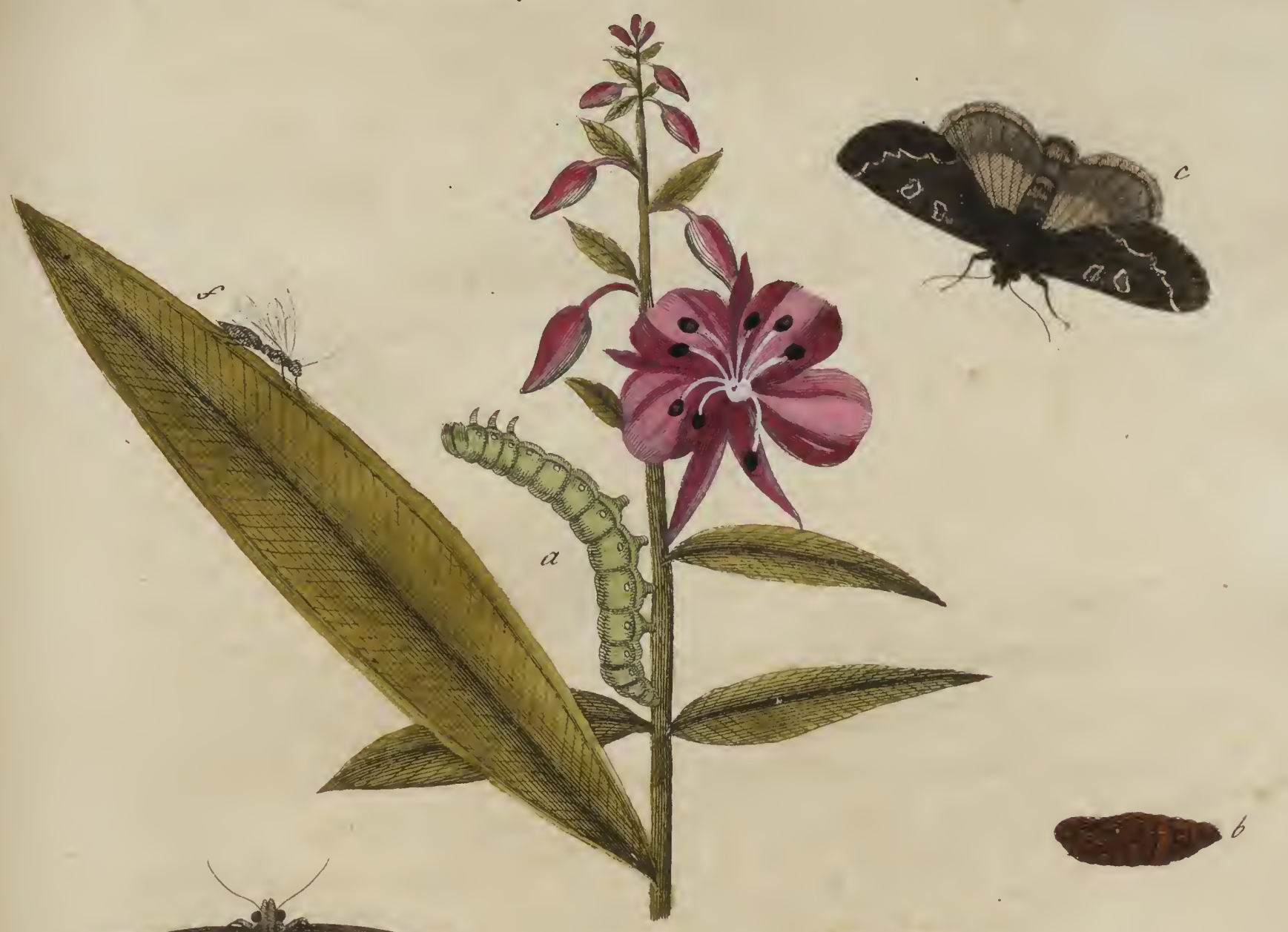

$d$
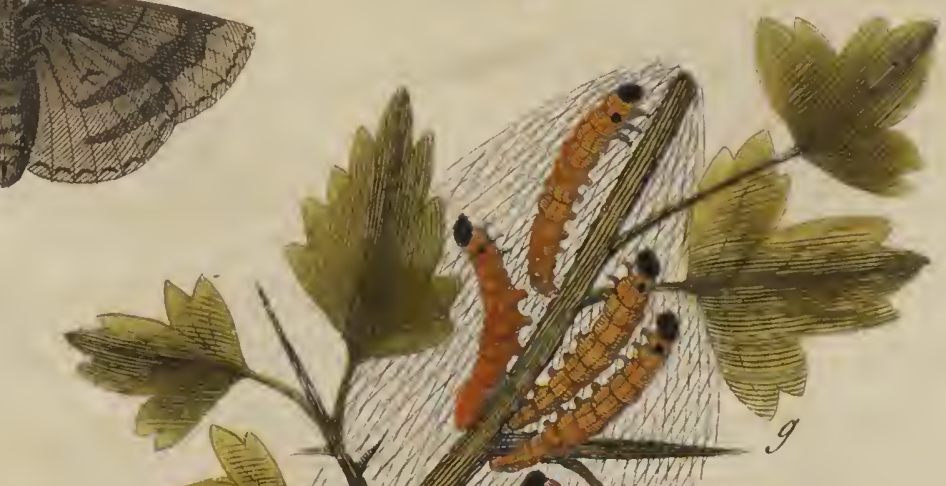

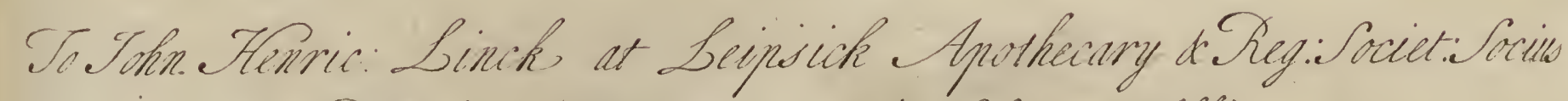
cThis Alare is humbly dedieand. Iny Bleazar Allins. 


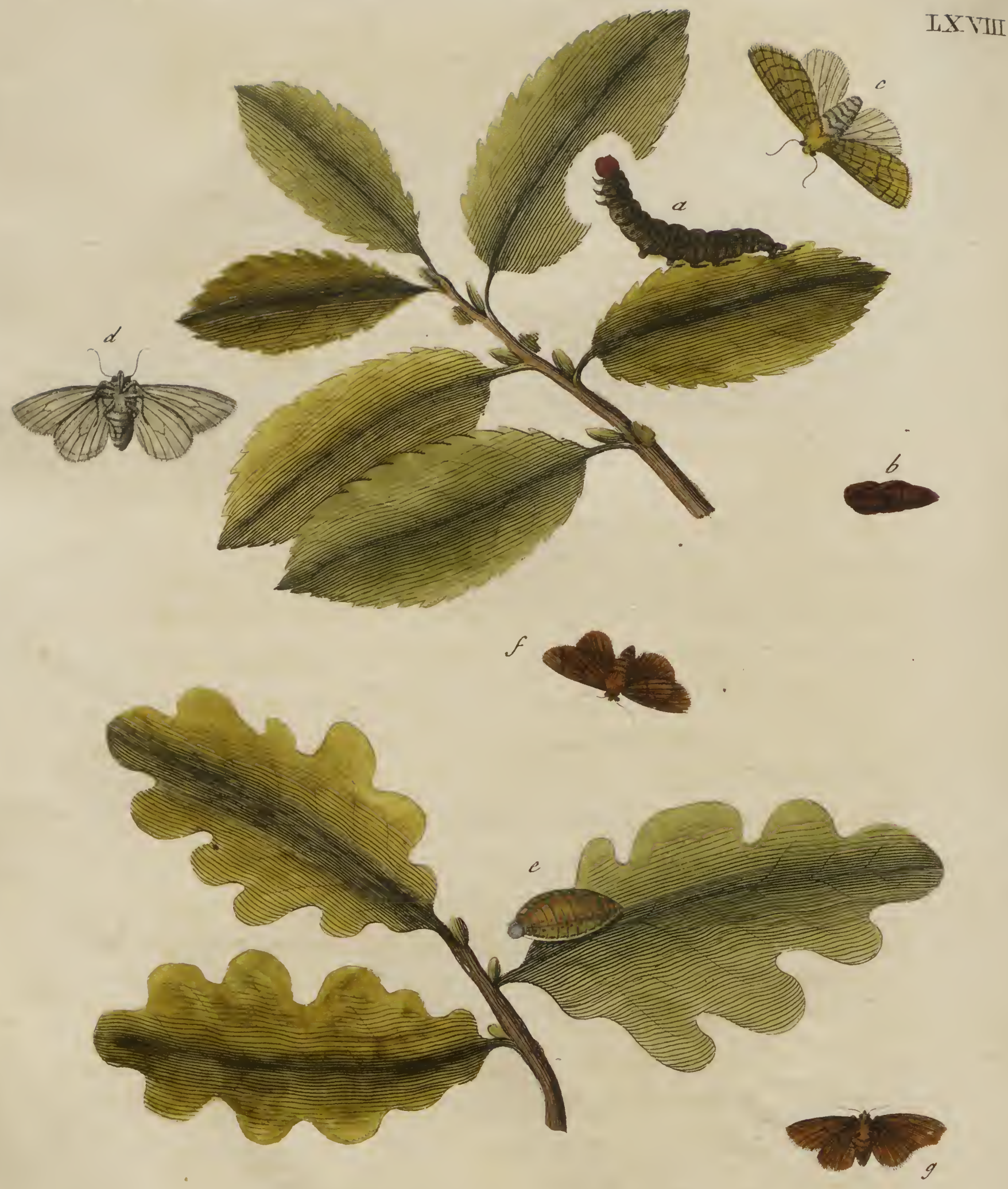

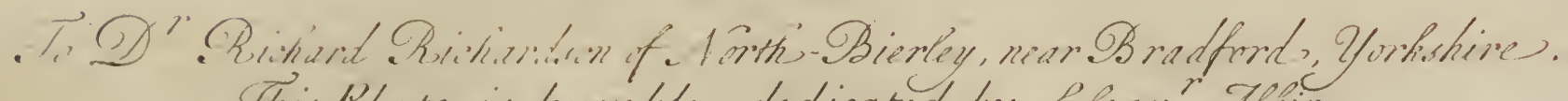

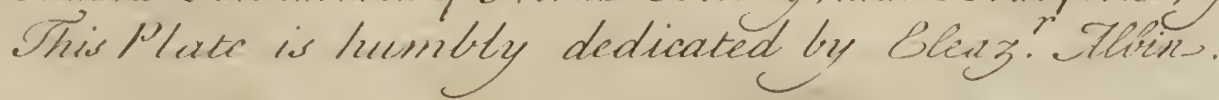


The Description of the Sixty Eighth Pl a TE.

THE Caterpillar, a, in this Table 1 was of a dark Colour, the Head red. It was taken on the Sallow near Hornfey Wood about the middle of May, and on the 26th of the fame Month it went into the Ground and changed into a Cbryfalis, b, the Motb came the $13^{\text {th }}$ of September, the upper Wings, c, Yellow, the under Wings and under Side, $d$, of a pale Cream Colour.

The Caterillar, $e$, was Green and fpotted with Red; I could not perceive it had any Feet; the Belly feemed wet or flimy like that of a Snail, it crept on the Leaves after the fame manner. It was taken on the $2 \mathrm{~d}$ of September on the Oak, and fed till the 2oth; it then fpun up in the Leaves, and the 29th of May came the Mothexpreffed at $f, g$, in the Table. 
The Description of the Sixty Ninth PL A TE.

THE two Caterpillars in this Ta1 ble are of one Species though differently marked; the firft, at $a$, was Green fpotted with Red. It was found on the Oak the 5 th of $O c$ tober. The other, at $b$, was Green with a red Protuberance on its Tail. It was found on the Maple near Highgate the 2oth of September; when it ftood ftill, it always lifted up its binder Part. They went into the Ground at the End of October, and about the latter End of February came the Motb expreft at $d, e$. 


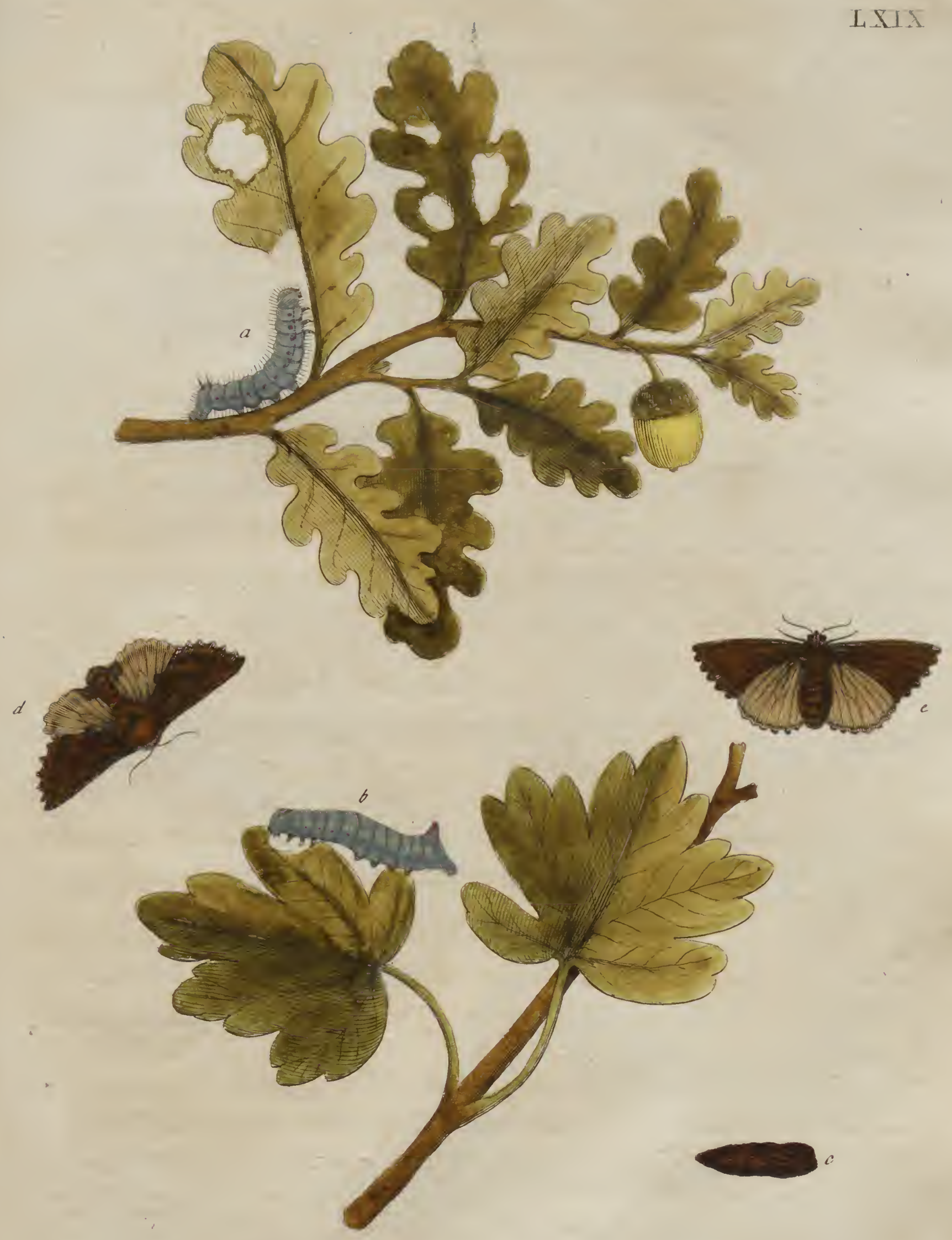

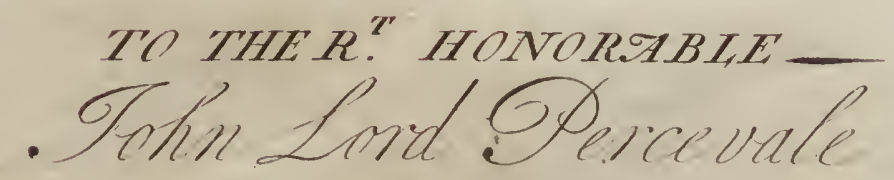

this Plate is humbly dedicated by Eleazars Albins. 


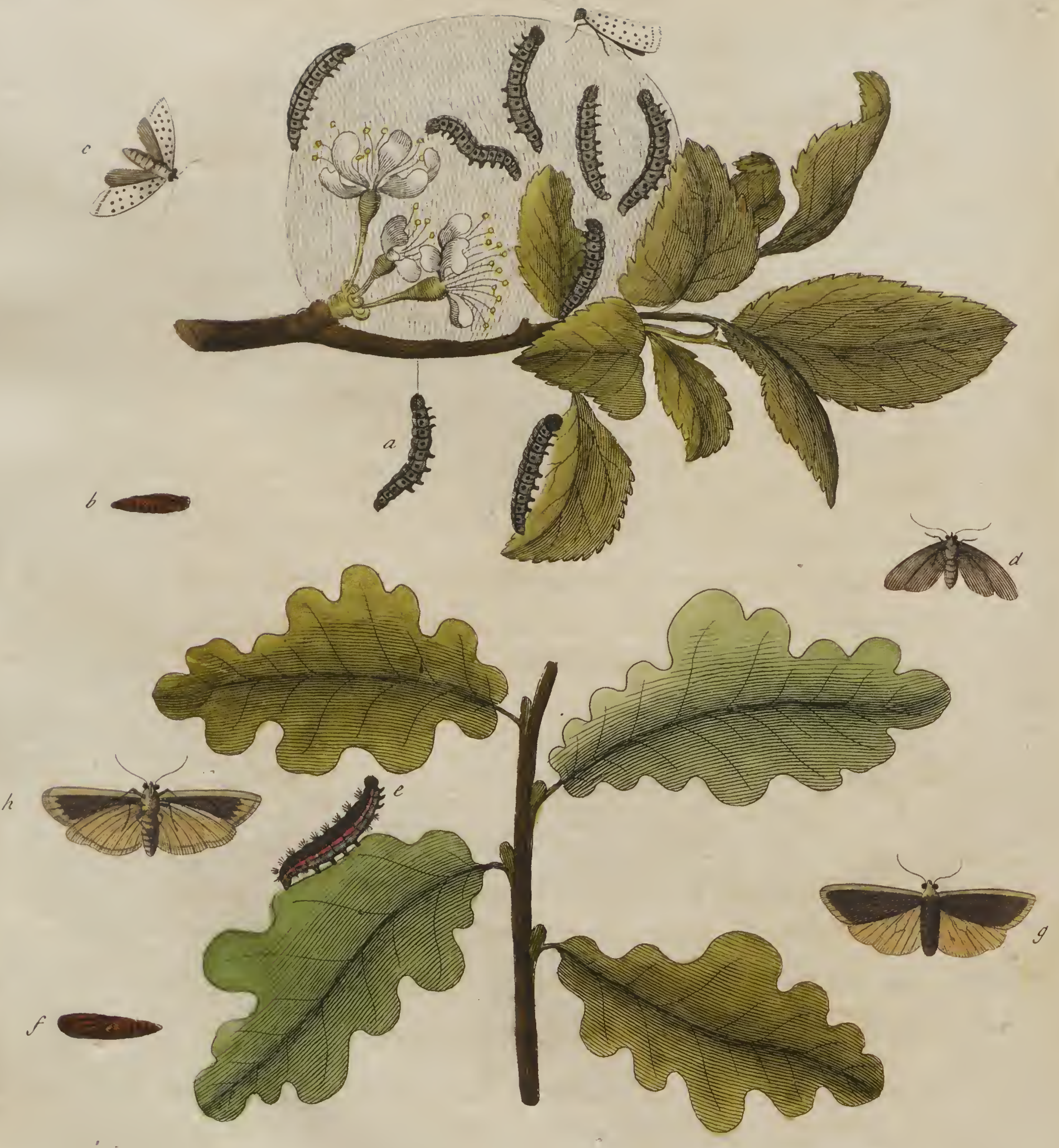

To. II. Glizabeth. Bridges of. Soho. Funare

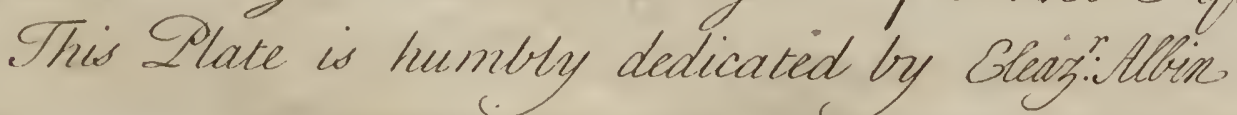


The Description of the Seven. tieth PLA'TE.

THE black Caterpile ars of this Ta-

1 ble, at $a$, fed in a $W e b$ together on Black Thorn, White Thorn, and Plumb Tree. They were found at the latter end of May and changed into Chryfalies the beginning of Fune, and the 20 th of the fame Month came the Moth, $c, d s$ commonly called the Ermine.

The Caterpillar, e, was brown on the Back, the Belly Ath Colour parted from the Brown by an Orange-colour'd Stripe, its Head Black. It was found on the Oak the 26th of May: it fpun up the 1 5 th of Fune and changed into Cbryjalis, the Motb came the I oth of "Fu $l y, g, b$. 
The Description of the Seventy Firft Plate.

THE CATERPILLAR in this Table, at $a_{3}$ 1 was Green ftriped with White. It was found on the white Archangel in the Beginning of $\mathcal{F} u l y$, andabout the middle of the fame Month it fpun it felf up in a tranfparent $W e b$, and changed into a Cbryfalis, $b$; the 2oth of Auguft came the Moth, d, the dark Shades of the upper Wings is brownifh, the light parts like burnithed Brafs, the underWings and under Side of a Hair Colour.

The fmall Maggot, at $e$, was of a brownifh Colour full of Briftles. It was taken in Rabbet's dung in the middle of October, and at the end of the fame Month it changed, the Briftles remaining on the Cbryfalis, $f$, and in the middle of March came the fmall Houfe-fly, g. 


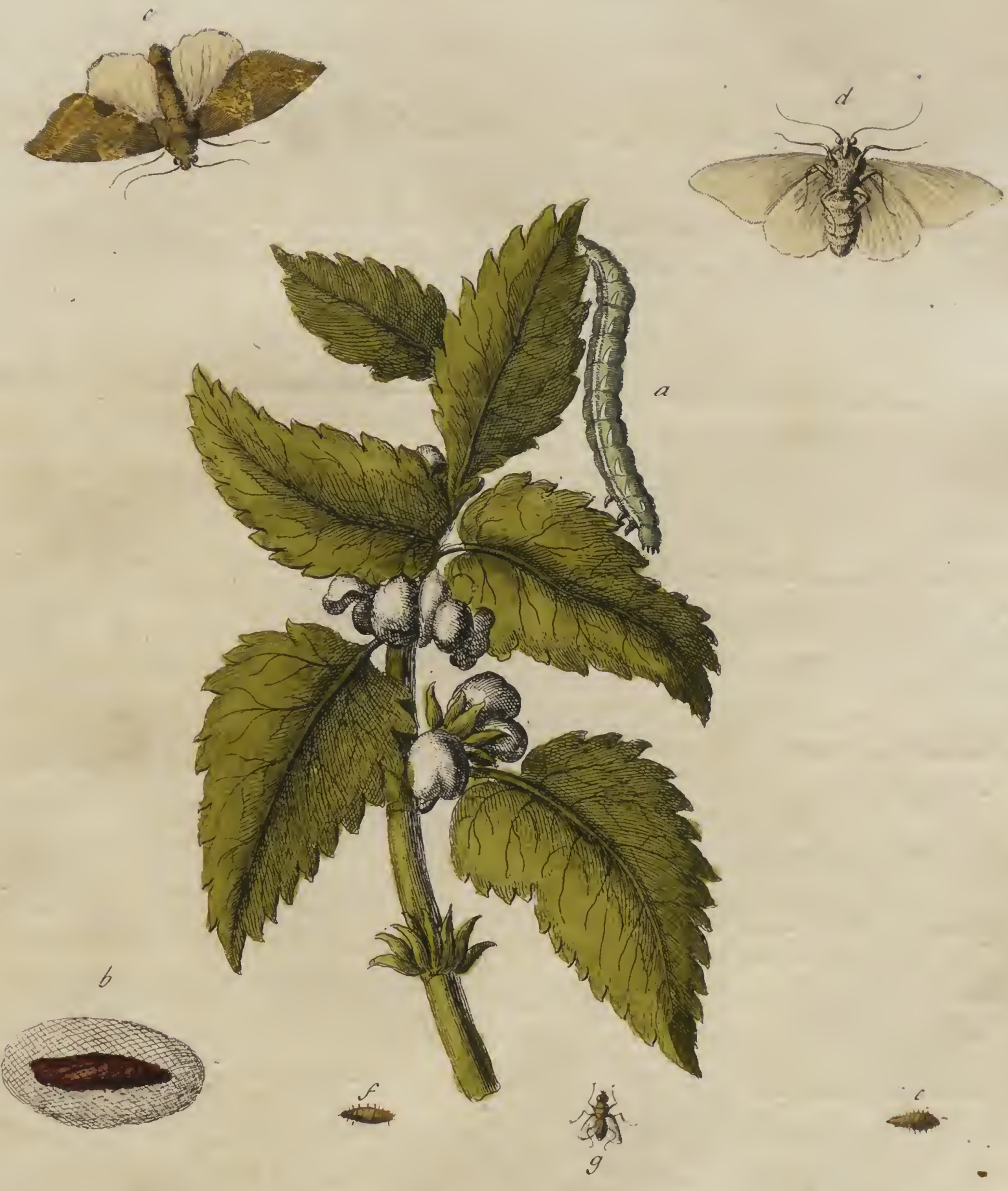

TO THE. TOST TOBLE

- Tavies Euke of Chandois

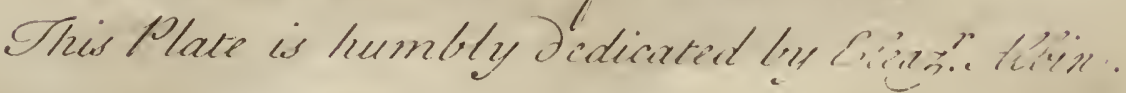



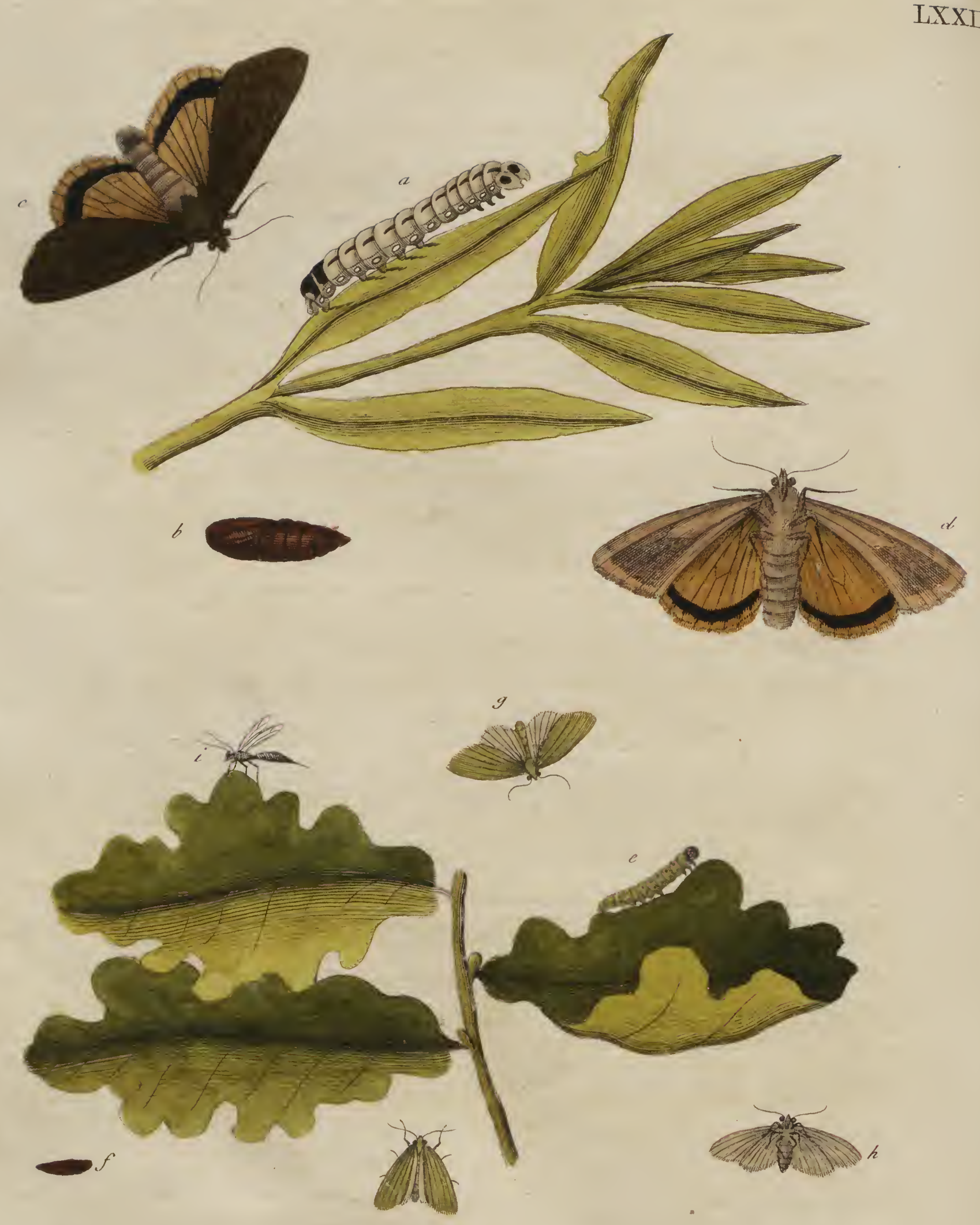

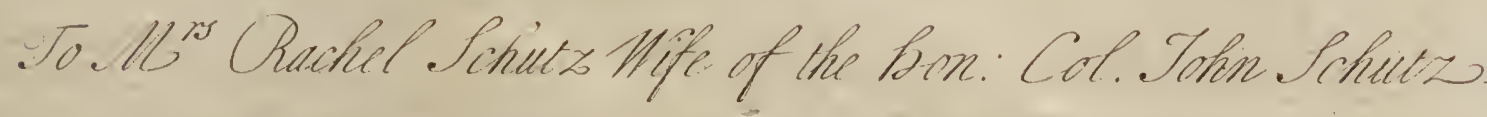
This Plane is humblly dedicared by Gleas?" Albinn. 
The Description of the Seventy Second Plate.

THE Caterpillar, $a$, in this Table 1 was of a light Brown fpotted with Black and White. It was found feeding on the fweet Williams in a Garden near Hackney, on the 4th of May, and the roth of the fame Montbit went into the Ground and changed into Cbryfalis, $b$, and the Ioth of Fune came the Moth commonly called the yellow under Wing, $c, d$. See $L i f t$ er on Godart, page 52. $N^{\circ} 4 \mathrm{I}$.

The Caterpillar, $e$, in this Tablewas Green, and fpotted with Black. It was found folded up in the Leaves of the Oak the 24th of May, and the 27th of the fame Month it fpun it felf up and changed into a Chrysalis, $f$; the Moth; $g, b$, came the I 8 th of Fune. It was of a beautiful green Colour. From fome of thefe CA T E R PI L L A R S came the Icbneumon figured at $i$, in the Table. 
The Description of the Seventy Third PLATE.

THE Caterpillar, $a$, in this Table I was of a light Green. It was found folded up in the Leaves of the great Nettle at the end of May, it fed after the fame manner of the CA TER P IL L A R sin Table 37. It changed into a Chryfalis, $b$, in the Beginning of Fune, and in fourteen Days came a beautiful Moth, $c, d$.

The Head and Back of the CATERPILLAR, e, was of a pale Rofe Colour, the Belly. Green. It was found folded up in the Wood. bine Leaves near Hornfey-wood on the $22 \mathrm{~d}$ of May. It was one of the nimblet CA TER PILLARs I ever met with, for if you touch'd it: never fo little, it would leap about like a mad thing; It fpun up the Day after it was taken, and changed into a Cbryfalis, at $f$, and the Moth g, $b$ came the r 4 th of $f u n e$. 


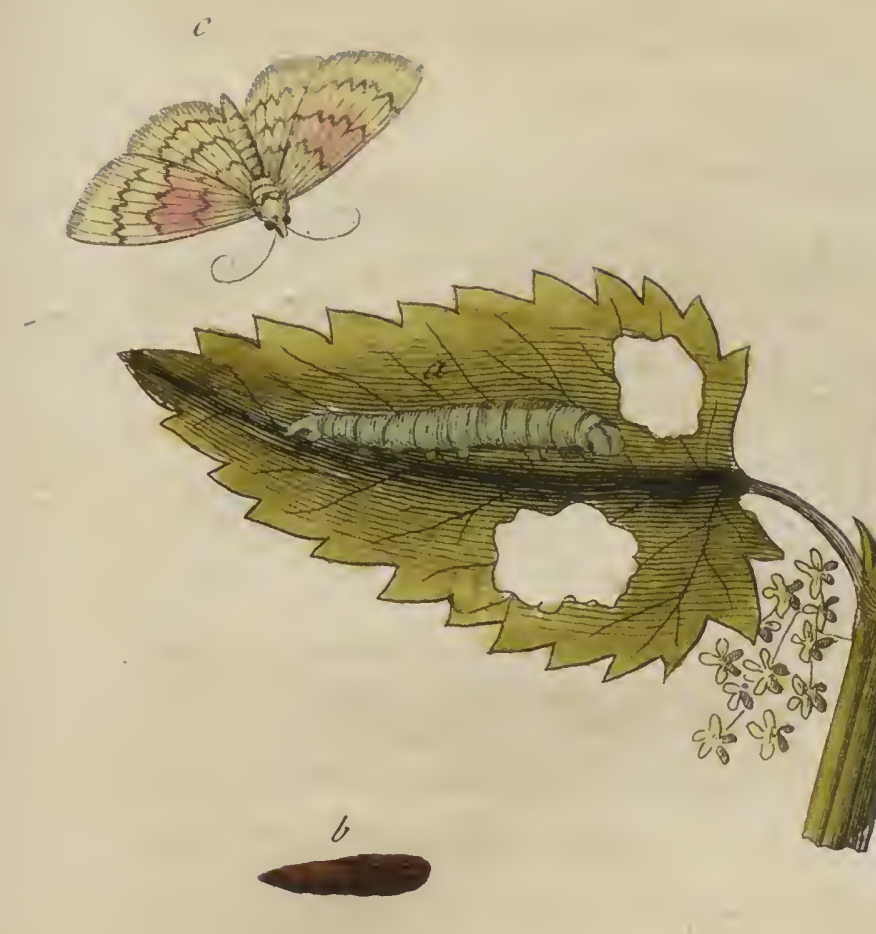

$-$
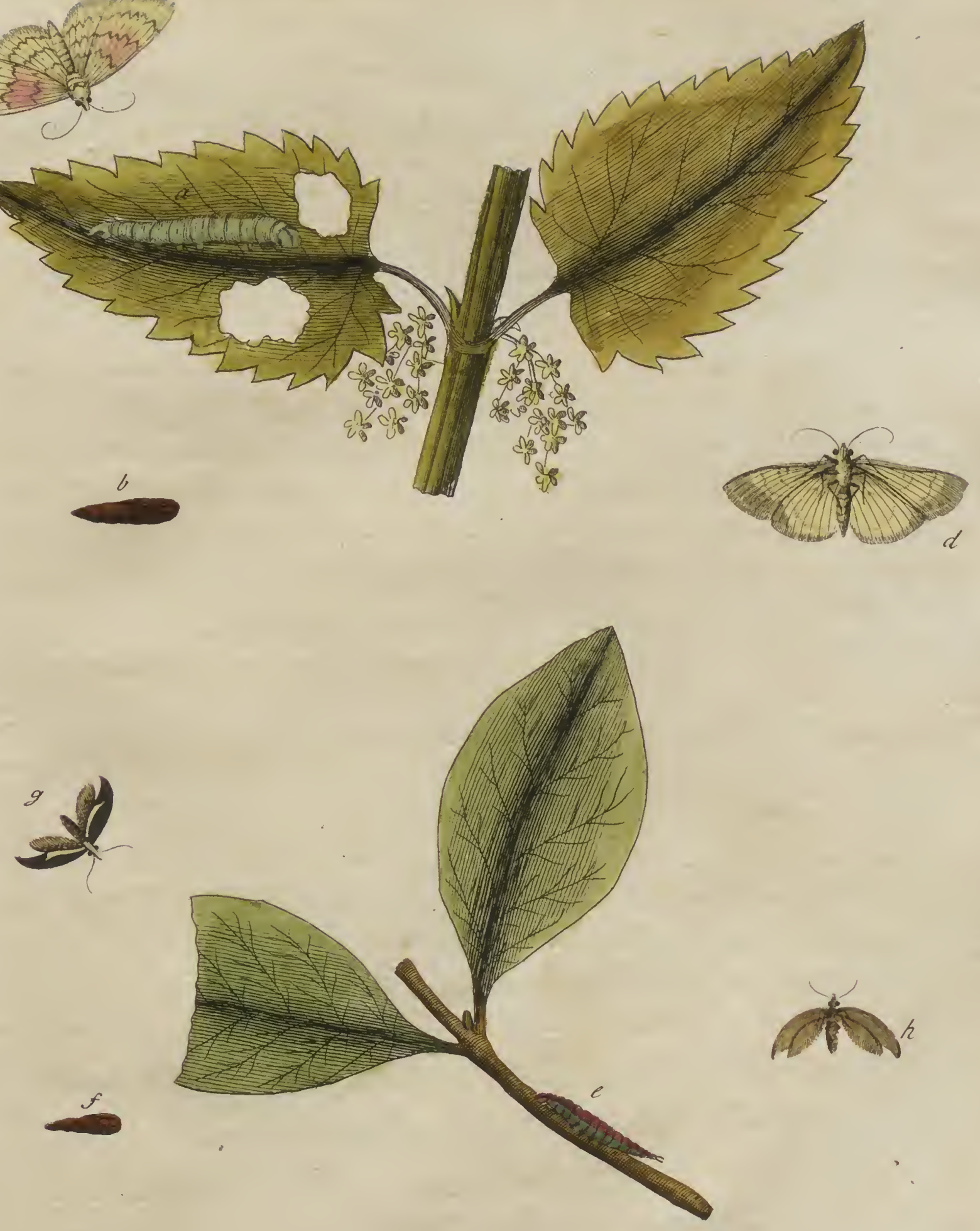

- Oo. Brook. Bridges Gisti?

This Plate is humbly dedicated by Glenz."Athin 

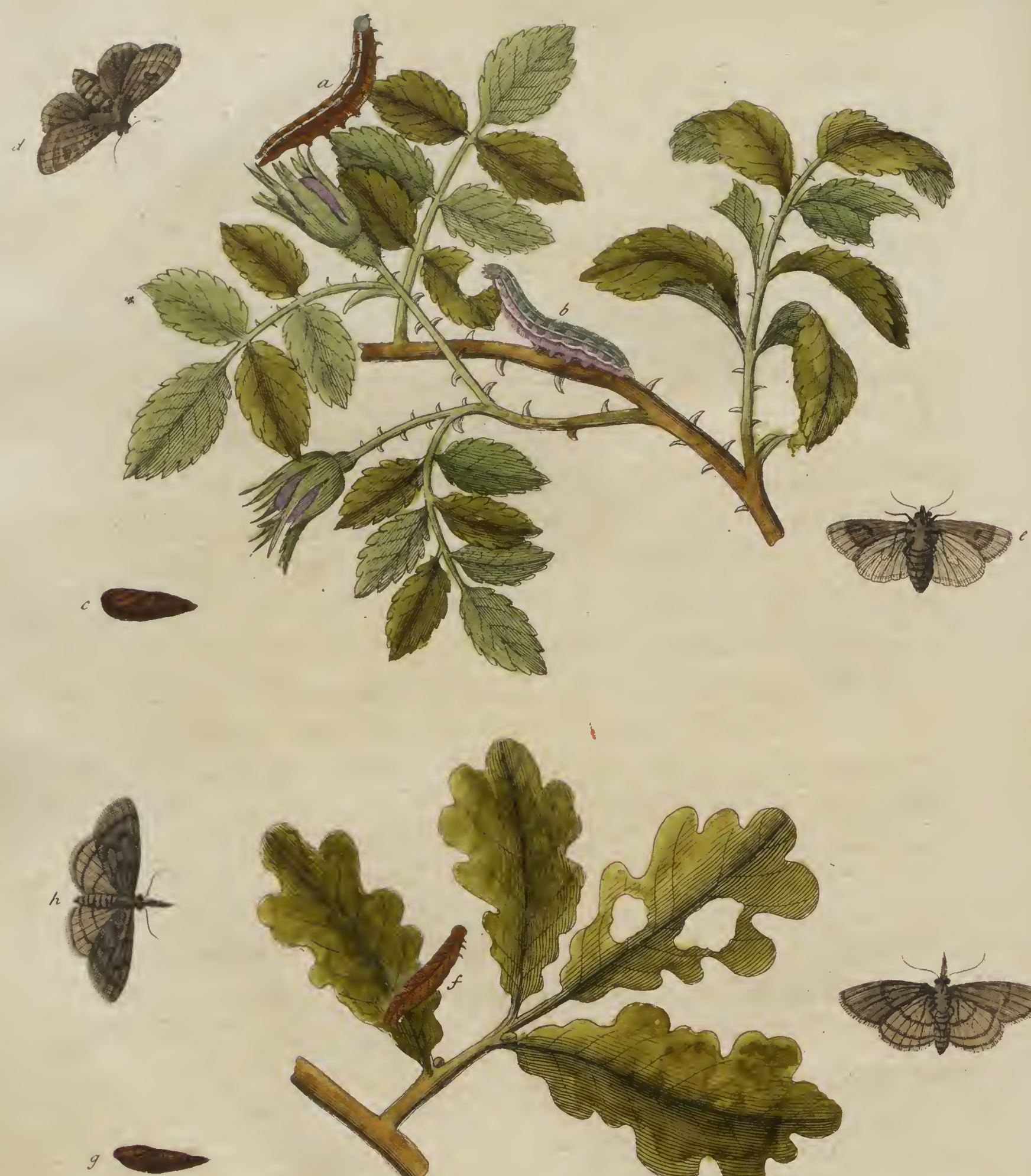

$$
\text { Ll Revno gré Don OBruno Toxsi }
$$

Gocumere generale della Congregatione di Talontorosns Reg. Societs. Socio. 


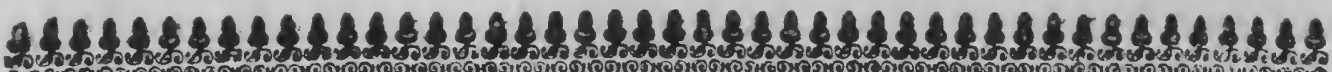

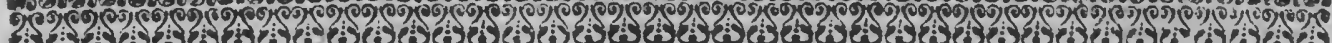

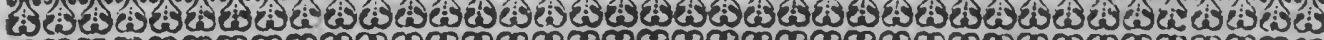

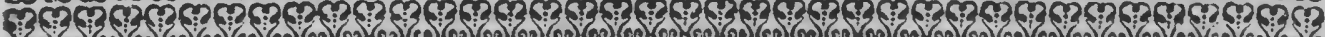

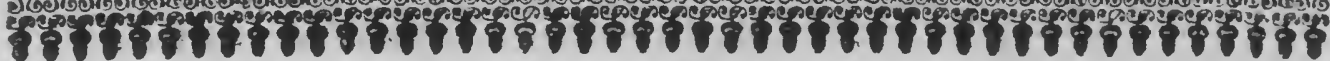

The Description of the Serventy Fourth PL A TE.

THE CAterpillars, $a, b$, were dif1 fering in Colour, fome Brown and Green, others Red and Green. They were found on the wild Rofe the 2oth of May near Hornfeywood, I had four of them in a Box, and looking on them half an Hour after they were put in, found but two; and obferving them more ftrictly faw one of them devour the other in a fmall fpace of Time: that which remain'd went into the Eartb in the Box, and changed into Cbryfalis, c, and the 2 Ift of February came. a brownifh $M o t h, d, e$.

\&

The Caterptluar, $f$, is Brown. Itwas: found on the Oak the $2 \mathrm{~d}$ of Suptember, and towards the latter End of the fame Month it changed into Chryfalis, $g$, and the $13^{\text {th }}$ of $A$ pril came the Moth, $b, r$. 
The Description of the Seventy Fifth Plate.

THE Caterpillar, $a$, in this Table 1 was of a yellowifh Green, the Head blueith. It was found feeding on the Oak; (I have likewife found of them on the Hafle; and on the Lime-trees in St. Fames's Park.) It went into the Ground the 1 gth of Fune and changed into Cbryfalis, $b$; and the roth of February came the Moth, c, d.

The Caterpiliar, $e$, was of a pale Green. It was found feeding on the Female Fern the 2d of September by the Wood Side near Cibarlton in Kent, and the $13^{\text {th }}$ of the fame Month it went into the Ground and changed to a. Cibryjalis, f; and about the latter End of $A$. pril came the Moth, $g, b$. 

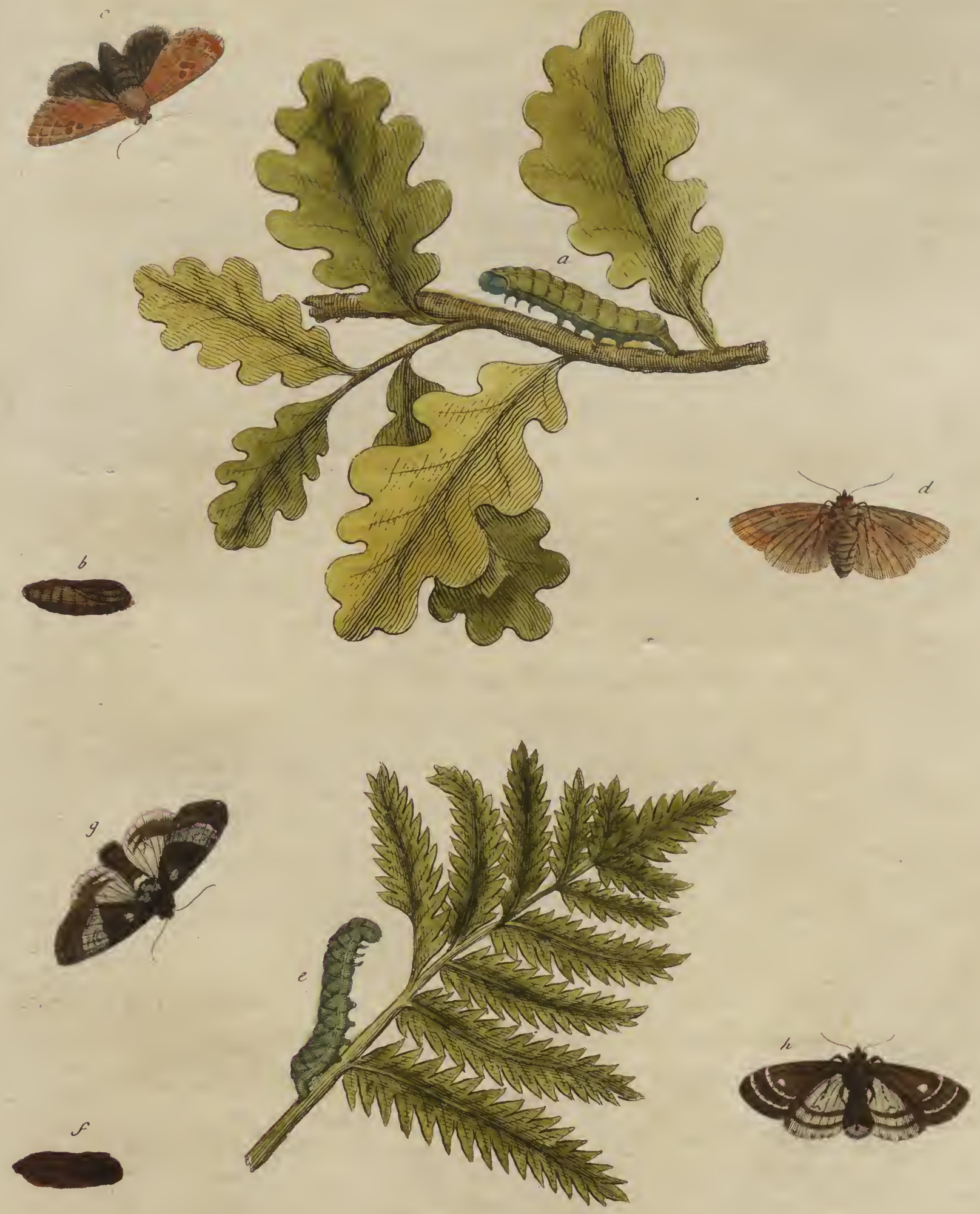

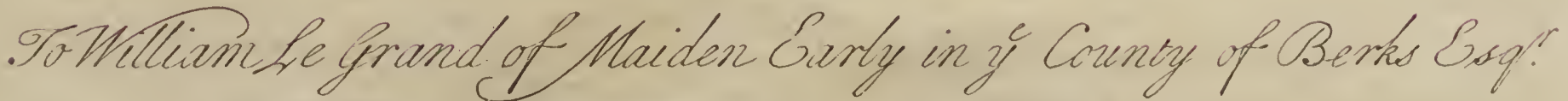
This place is humbly dedicated by Clens. Alline. 


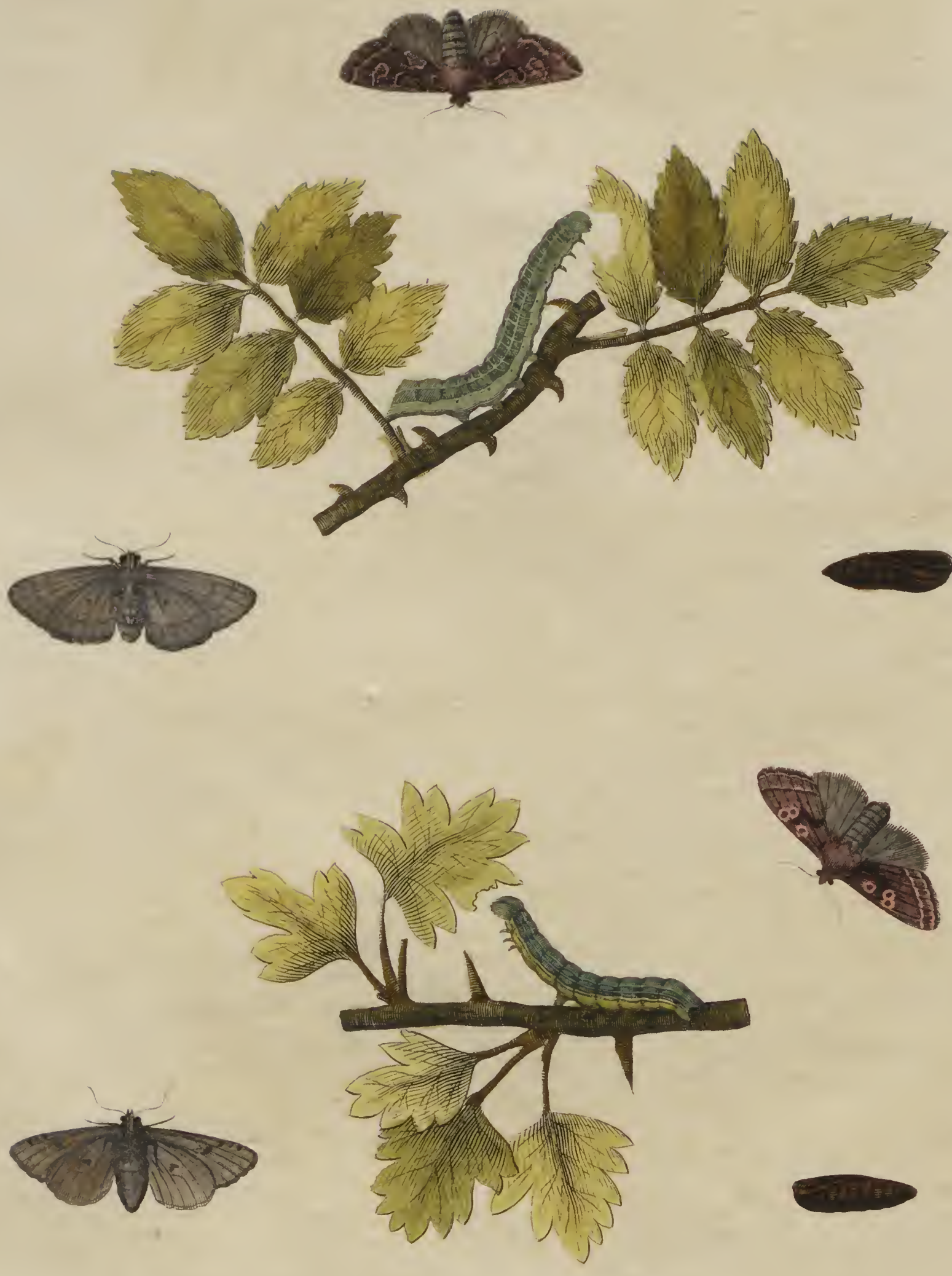

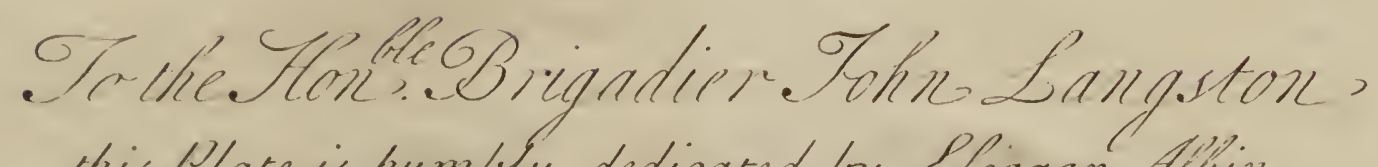
this Plare is humbly dedicaned by Pleinzar Rivin. 
The Description of the Serventy Sixth Plate.

\section{THE Caterpillar, a, in this Table} 1 was of a pale Green. It was found feeding on the Briar or wild Rofe 7ree the 16 th of Fune; and the 7th of Fuly it went into the Ground and changed into Chryfalis, $b$, the I6th of March came the Moth, $c, d$.

The Caterpillar, $e$, was Green on the Back, and yellowifh on the Belly. It was found on the white Thorn the r oth of Fune near the boarded River, and the 19th of the fame Mon: $b$ it went into the Earth and changed into Cbryfalis, $f$; and the s 3 th of February came the Moth, $g, b$. 
The Description of the Serenty Seventh Plate.

HE Green Caterpiliar, $a$, on the Net-
$t l e$, was found at the Beginning of $A u$ guft, and on the 24th of the fame Month it went into the Earth and changed into a Chryfalis, $b$, and the Beginning of May came the Moth, c, d.

The yellowifh C A ter P IL L AR was found feeding on the Facea nigra or Knap-weed the IIth of September, and the r 6th of the fame Month it went into the Earth and changed in. to a Chryfalis, and produced a Moth like the the former, the Body and upper Wings very dark with a Spot of White in each, the under Wings and under Side of a Hair Colour. 

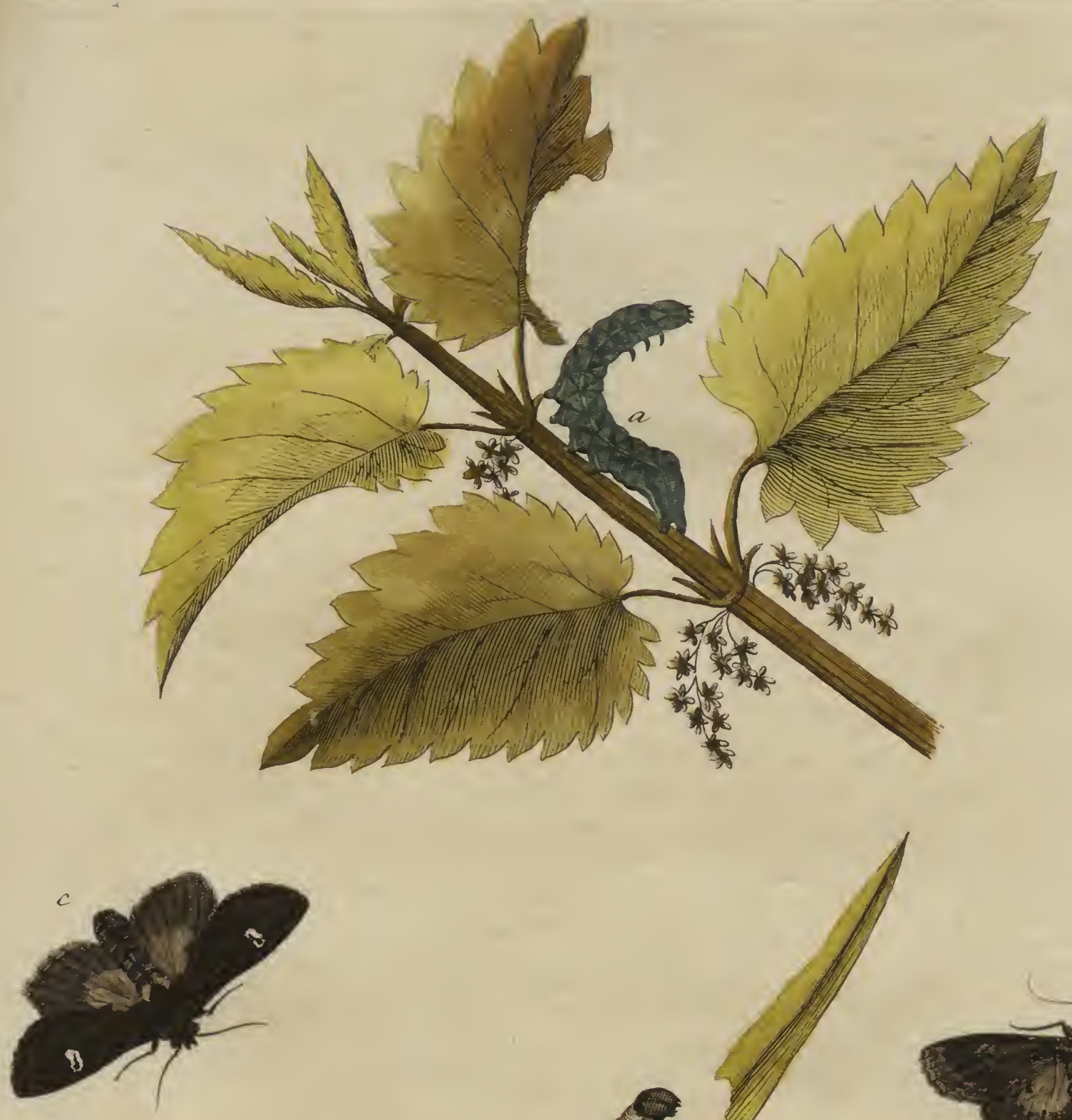

6
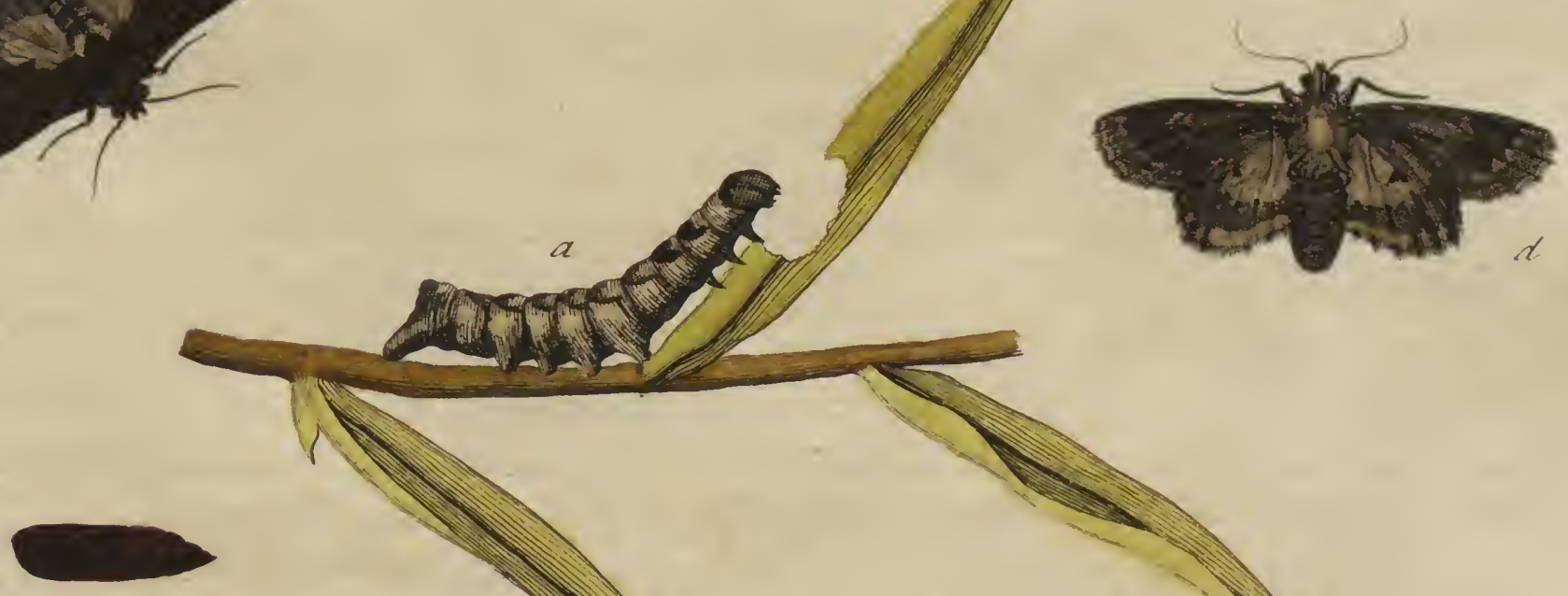

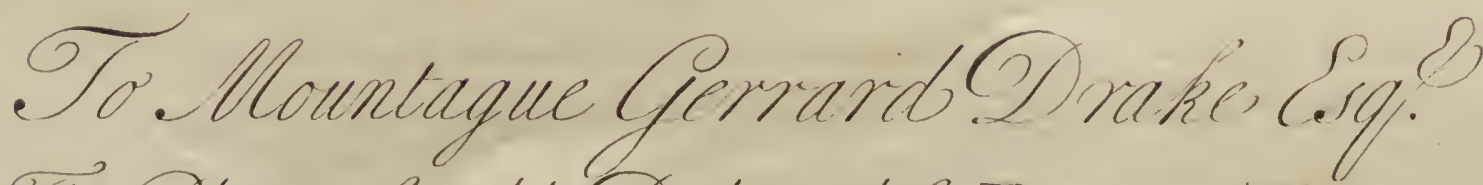

This Plate is humbly Odedicaled by Eleazar Allin. 


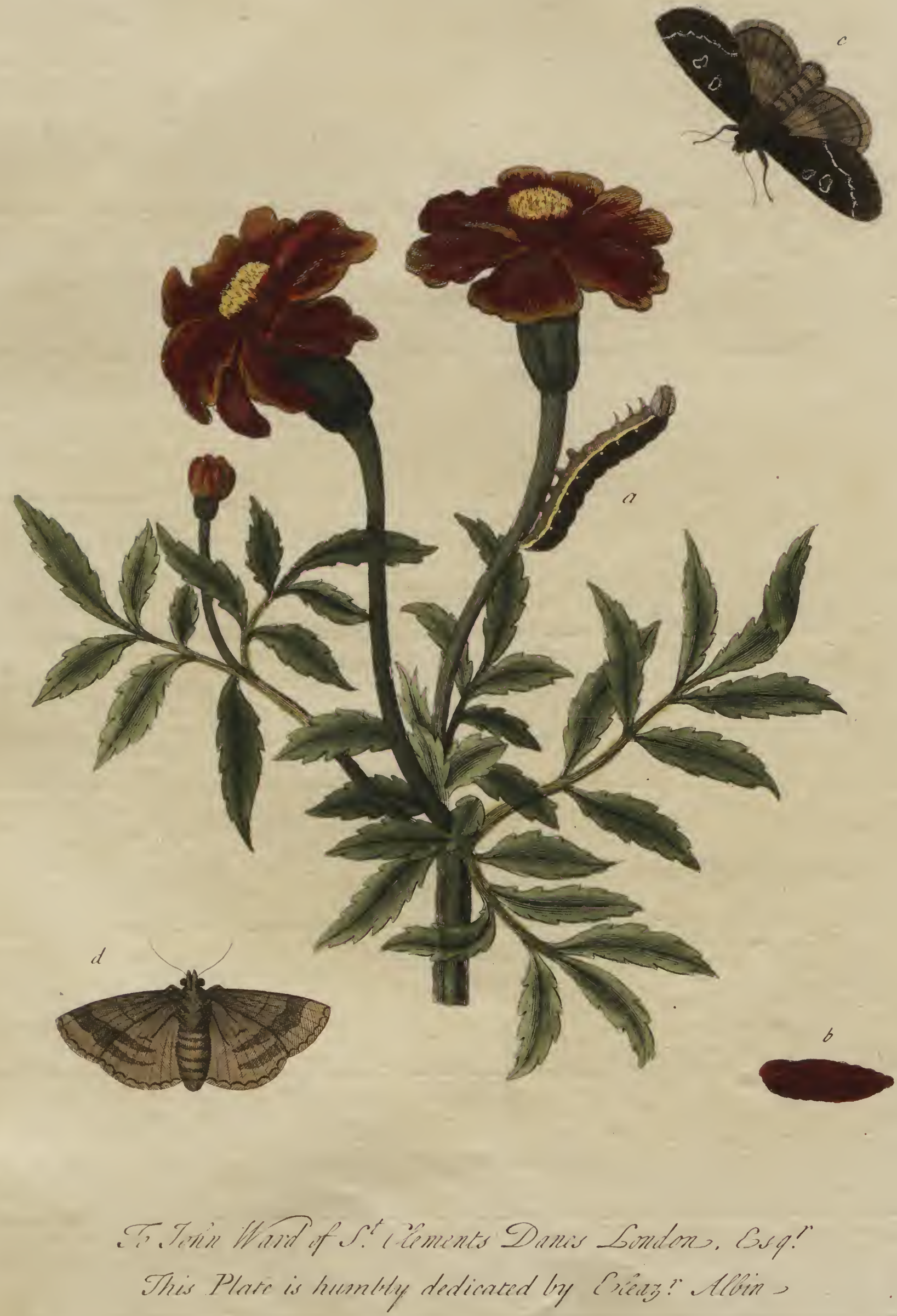


The Description of the Seventy

$$
\text { Eighth Pla te. }
$$

THE CAterpillar, a, was Black on 1 the Back, the Headand Belly of a muddy Green parted from the Black by a yellow Stripe on each Side, the Spots reprefenting Eyes reddifh. It was found feeding on the African Marygold at the Beginning of September, and the latter End of the fame Montb it went into the Earth and changed into a Corryfalis, $b$, and the Motb $c, d_{2}$ came the 23d of May following. 
The Description of the Serenty Ninth P L-A TE.

TE Caterpillar, a, in this Table
was Yellowifh with dark Clouds. It was found feeding on the Garden Creffes the 2d of Auguft, and the I Ith of the fame Month it went into the Ground and changed into Cbryfalis, $b$; the Moth, $c, d$, came the I 4 th of May.

The Green Cater PIL LAR, $e$, was found feeding on Mint the 4th of Augu/t, (they feed alfo on Burdock, Colts-foot and Parfley;) the two Holders in the middle of the Body on each Side of this CATERPILLAR are very remarkable, in which it differs from all that 1 have yet obferved. It fpun up within two Days after it was taken, and on the 24th of the fame Month came the Moth, $g, h$, commonly call'd the $\mathrm{Y}$ Moth, from having a Mark in the middle of each upper Wing fomewhat refembling that Letter. See Lifter on Goddart page 20. $N^{\circ} \mathrm{I} 4$. 

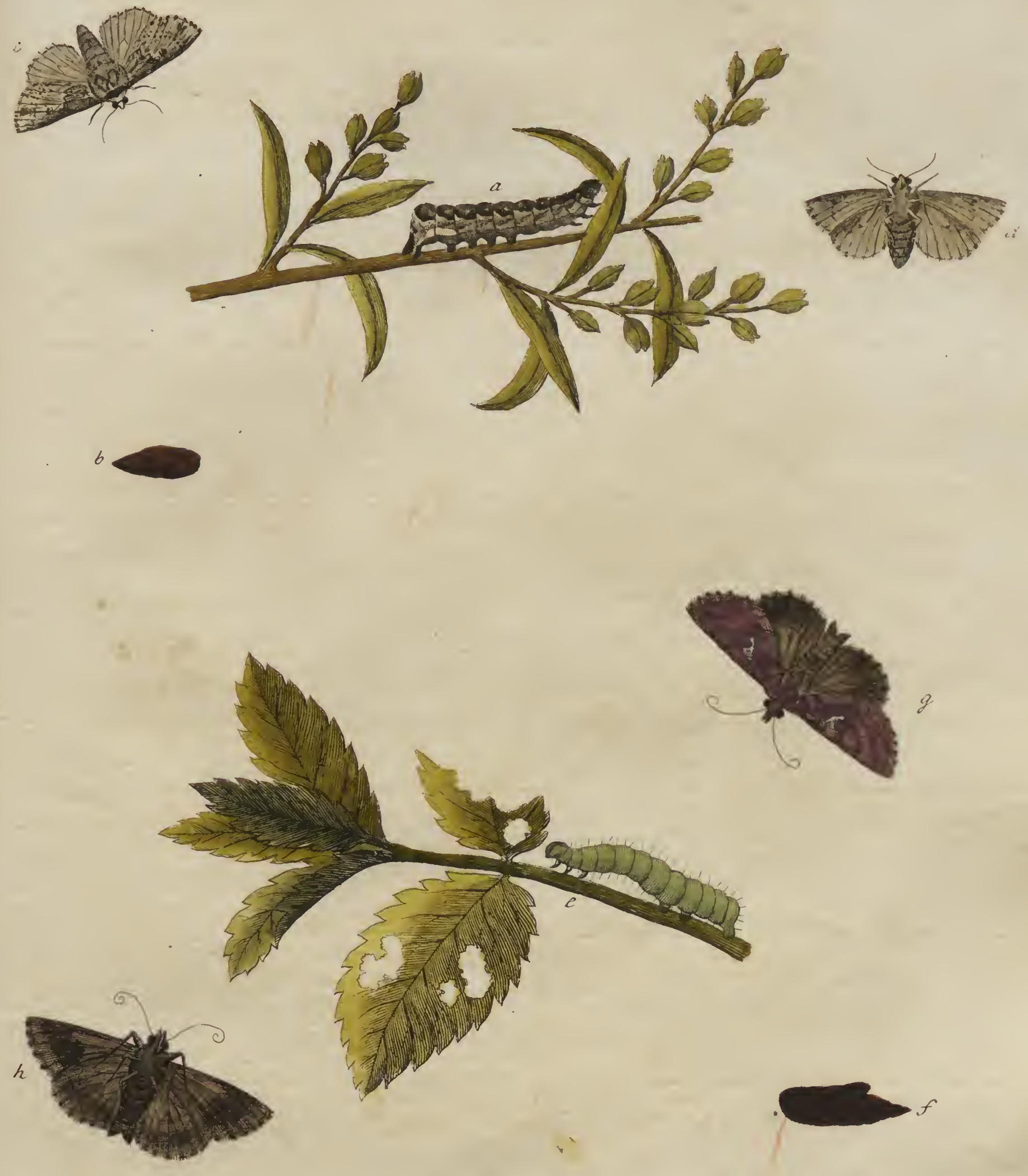

To Themas Windham of. Manvkichurch in the County of Dorset

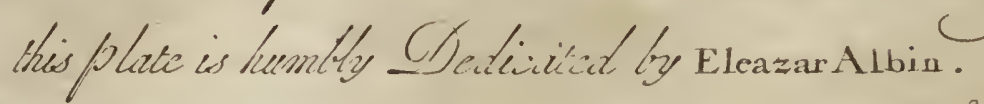



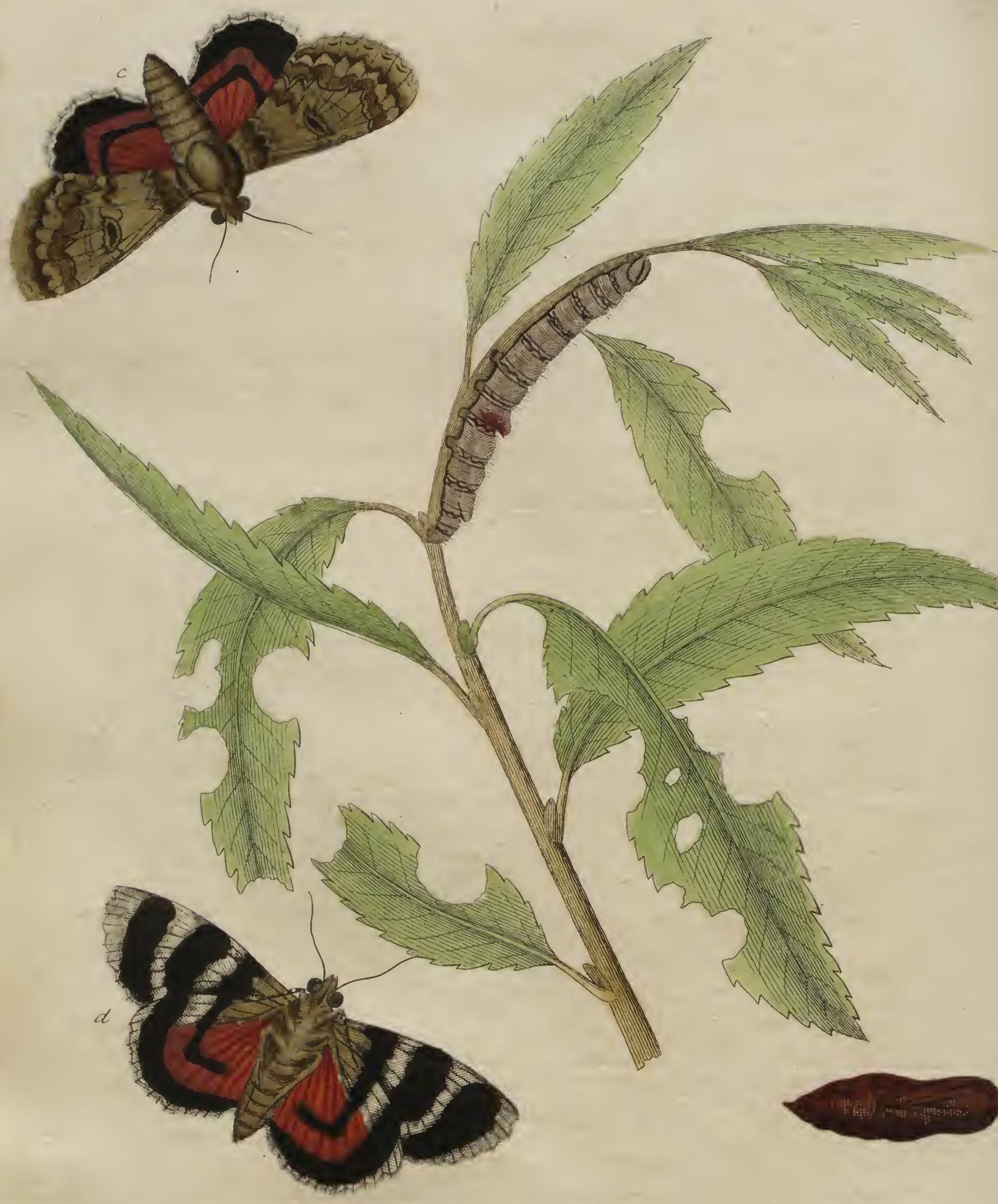
The Description of the Eightieth PLATE.

THecaterpillar, a, was Brownifh, 1 having a Protuberance on the middle of his Back and another on his Tail, with a Shade of Red under the former. I found it on the Willow, by the Thames-fide at Chelfea Phyfickgarden the I2th of Fune, and the 17th it fpun it felf up between the Leaves in a thin $W e b$; and changed into Chryfalis, b, which was all over cover'd with a blueith White fomewhat like that on Plumbs; the Moth, $c, d$, came the 17 th of $9 u b$, it is commonly called the red under Wing. 
The DESCRIPTION of the Eighty Firft Pla TE.

THE CATERPILlar, $a$, in this 7able I was of a reddifh Brown or Fox Colour, with a black Stripe like Velvet at each Foint; the Head, Feet, Belly and Holders were Black. I found it about the Beginning of March, and fed it on the Bramble till the latter end of the fame Month, then it fpun a $W e b$ in which it turn'd into Chryfalis, $b$; the Beginning of May came the Moth, $c, d$; this CA TeR P L L AR, is called by the Country People the Devil's Gold Ring, but we diftinguifh it by the Name of the Fox.

This CATERPILLAR is frequently found in Autumn, and refemble the Ragweed CATERPILLAR, e, Table.34. When they are fmall, but thefe I could never bring to their Change. 


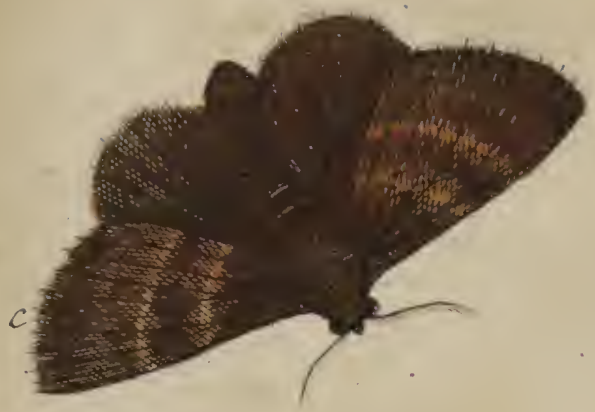

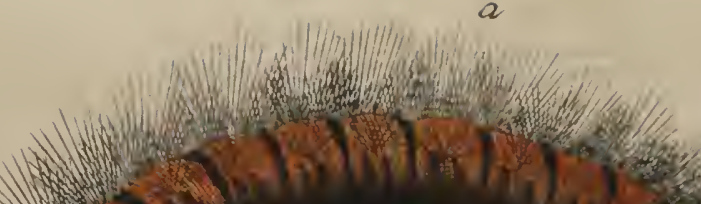

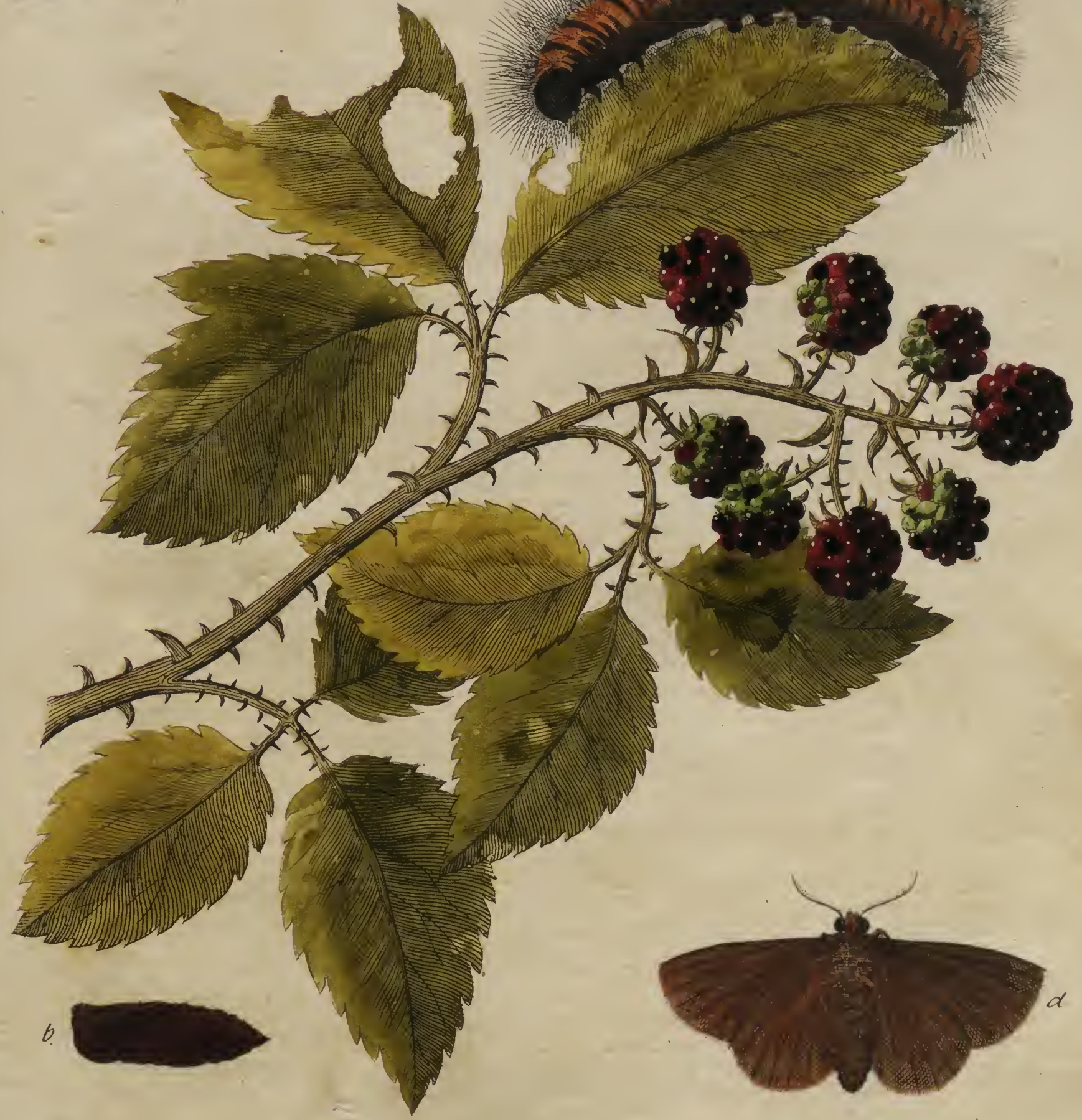

To the Right Honorabee

Shomias Garl of Pemlniken kllontgonuery, dec.

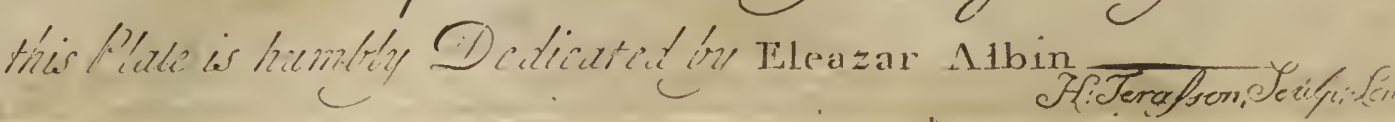



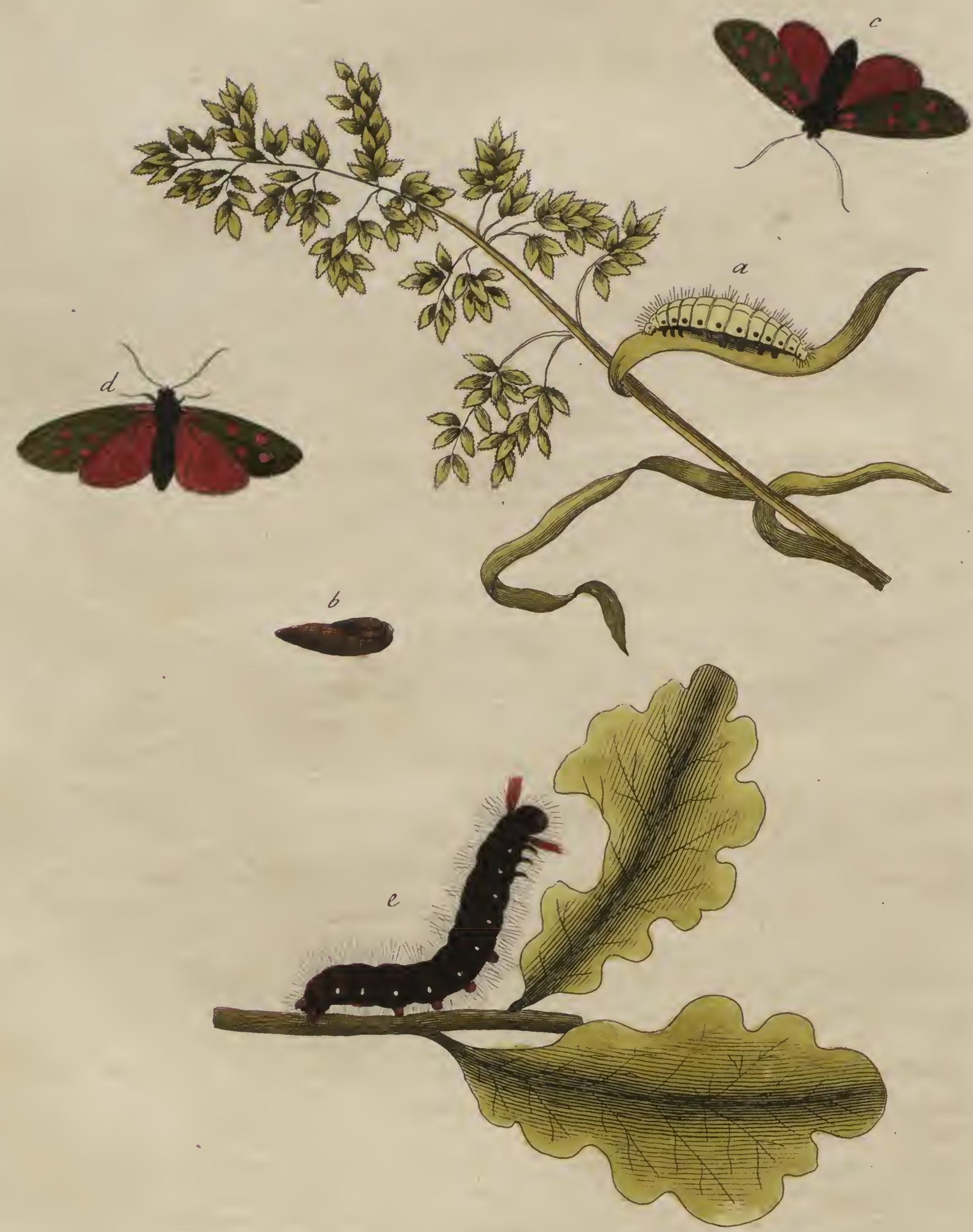

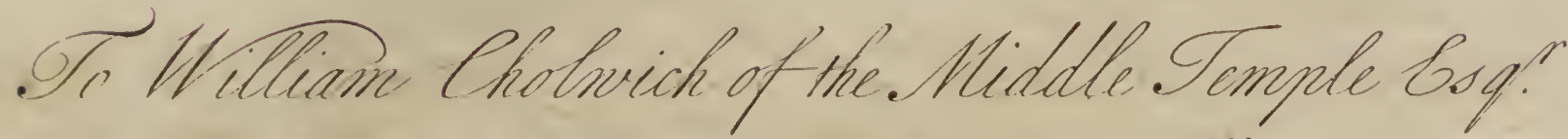
This Plate is humbly dedicated by Glenz." Albin. 
The Description of the Eighty Second PLA'TE.

'THE Caterpillar, a, in this Table 1 was of a yellowifh Colour with a Brown Head. It was found about the Beginning of May feeding on Grafs. Mr. Knowlton has obferved them in Hartford/hire to have devoured whole Fields of Saint-foin. It fpun it felf up in a yellowilh thining Cafe, and changed into a black Clorysalis the 24 th of May, the Moth, c, d, came the I 5 th of Fune, the upper Wings of a dark Green fpotted with Red, the under Wings all Red edged with Black: this is commonly called the Wood Leopard.

The Caterpiliar, $e$, was found on an Oak near Peckbam in Kent the I6th of Fune, a few Days after it caft a Skin, and then fed again for fome time afterward; it fpun its felf up in a thick Oval Caje, in which it died without Changing. 
The Description of the Eighty

\section{Third PL A TE.}

THE CATERPILlaR, $a$, in this Table. was Yellow with Tufts of Scarlet and Yellow. It was found feeding on the Sycamore Tree at the Beginning of Fuly; when you difturb it, it rolls it felf up like a Hedgebog, as is expreft on the Leaf; the I $3^{\text {th }}$ of Fuly it fpun it felf up mixing its. Hair with the $W e b$, and changed into a Chryfalis, and the Motb came the Ioth of Fune. From fome of thefe $\mathrm{C}_{\mathrm{A}}$ TER P I L L AR s that wereffy-blow' $d$ about three Weeks after they fpun up came Icbneumon Flies. 


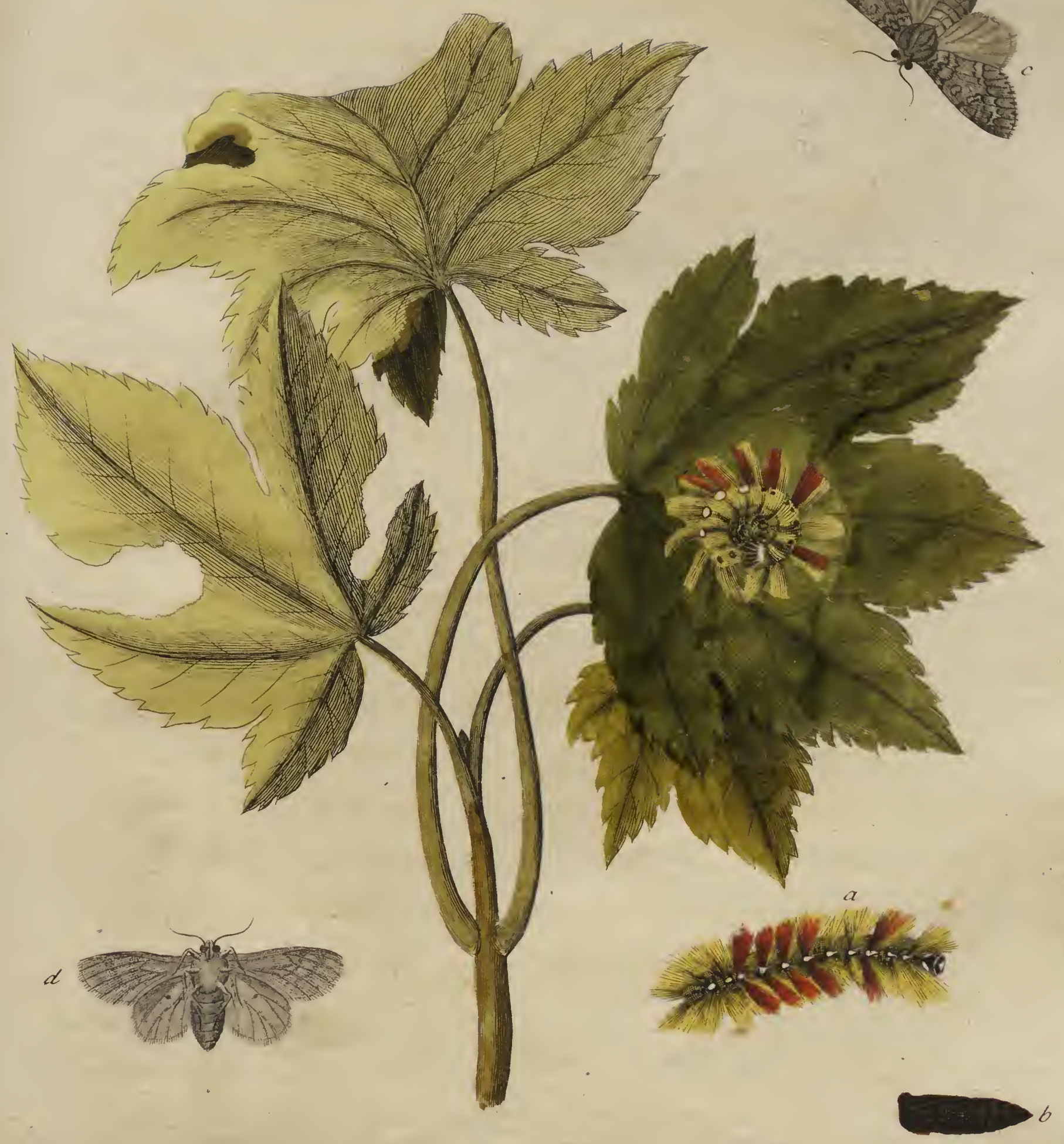

\footnotetext{
To the Right Honorable Lady. Nary Gores.
}

this plate is humblty Decticated by Eleazar Albin. 


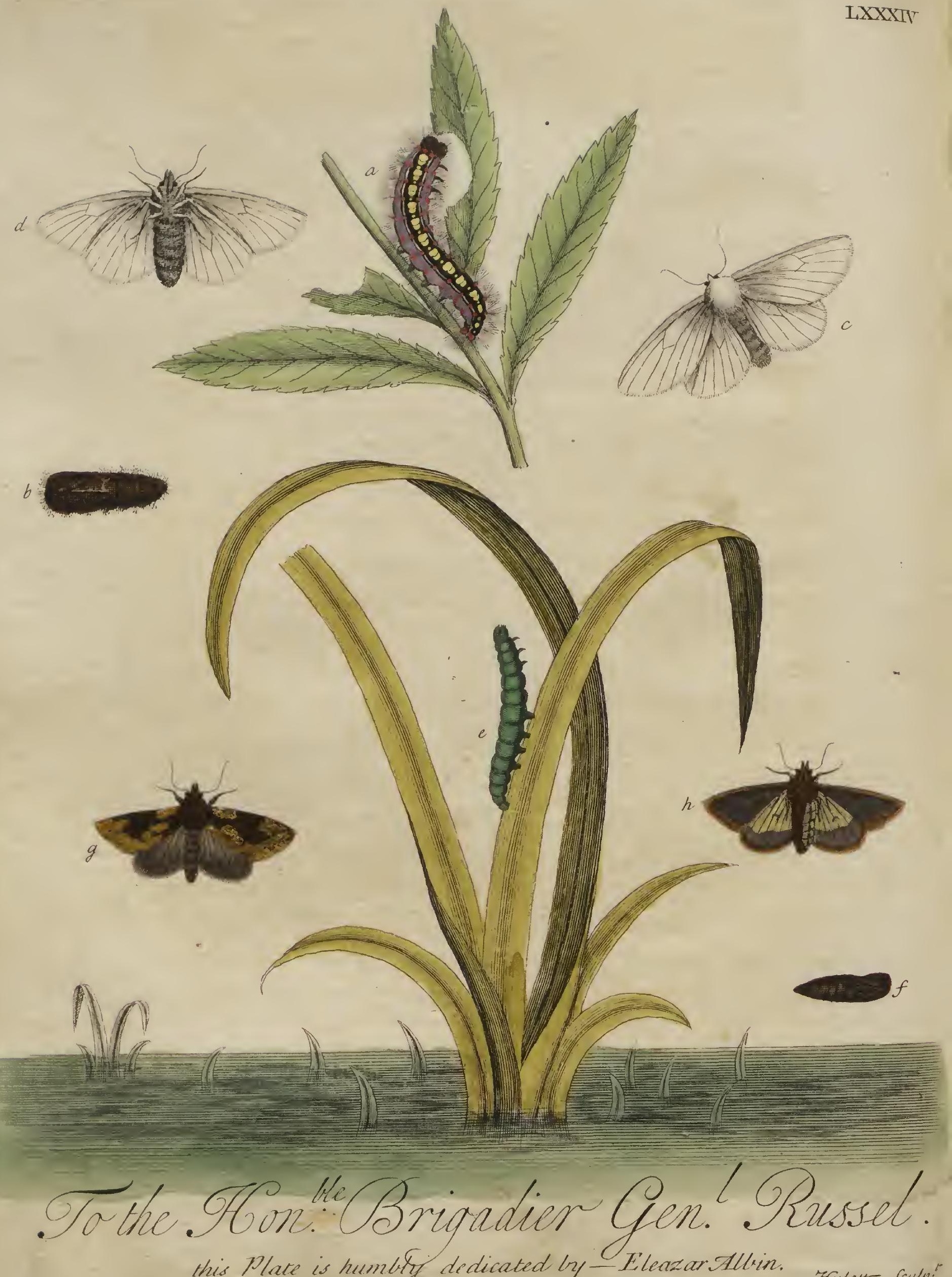

S. allin atel.

this Plare is humbery dedicated by - Eleazar Allin. 
The DESCRIPTION of the Eighty: Fourth PLATE.

THE Caterpillar, a, was Purple, 1 beautifully marked with Red and Yellow Spots. It was found on the Willow the I th of May, and the 4 th of Fune it fpun up: between the Leaves and changed into a hairy Chryfalis; the Moth, $d, e$, came the 24th of the fame Month, they lay Eggs of a pale Green Colour covered with a Subftance looking like Leaf Silver. The young CATERPILLARS were hatched the 28th and 29th of Fuly, and live all Winter. See Liffer on Godart, page 84. $N \circ 87$.

The Green Caterpilia $\mathrm{C}_{\text {, }} e$, was taken the 4th of Augu/t thinly fpun up in the Leaves. of the great Water-grafs in a Meadow near Rotherbith; in about two Days after it changed. into a Chryfalis, $f$, and the 17 th of the fame Month came a brownifh Moth, $g, h$, with Spots like burniff'd Gold in the upper Wings. 
The DEscription of the Eighty Fifth Plate.

THECaterpillars, $a, a$, werefound I on the Hafle the ift of 'Fune. I obferv'd them to eat very little, but upon giving them frefh Boughs which happened to be wet with Rain, they fed greedily. The next day I gave them Water and Honey mixed together, of which they drank a good Quantity and fell to eating again very heartily. In this manner, I fed them every day fometimes twice a-day till the i 4 th of the fame Month; they then went into the Eartband changed into Chryfalis; the Moth came at the latter End of December; $b$, c, fhow.s the Female, and $d, e$, the Male. 


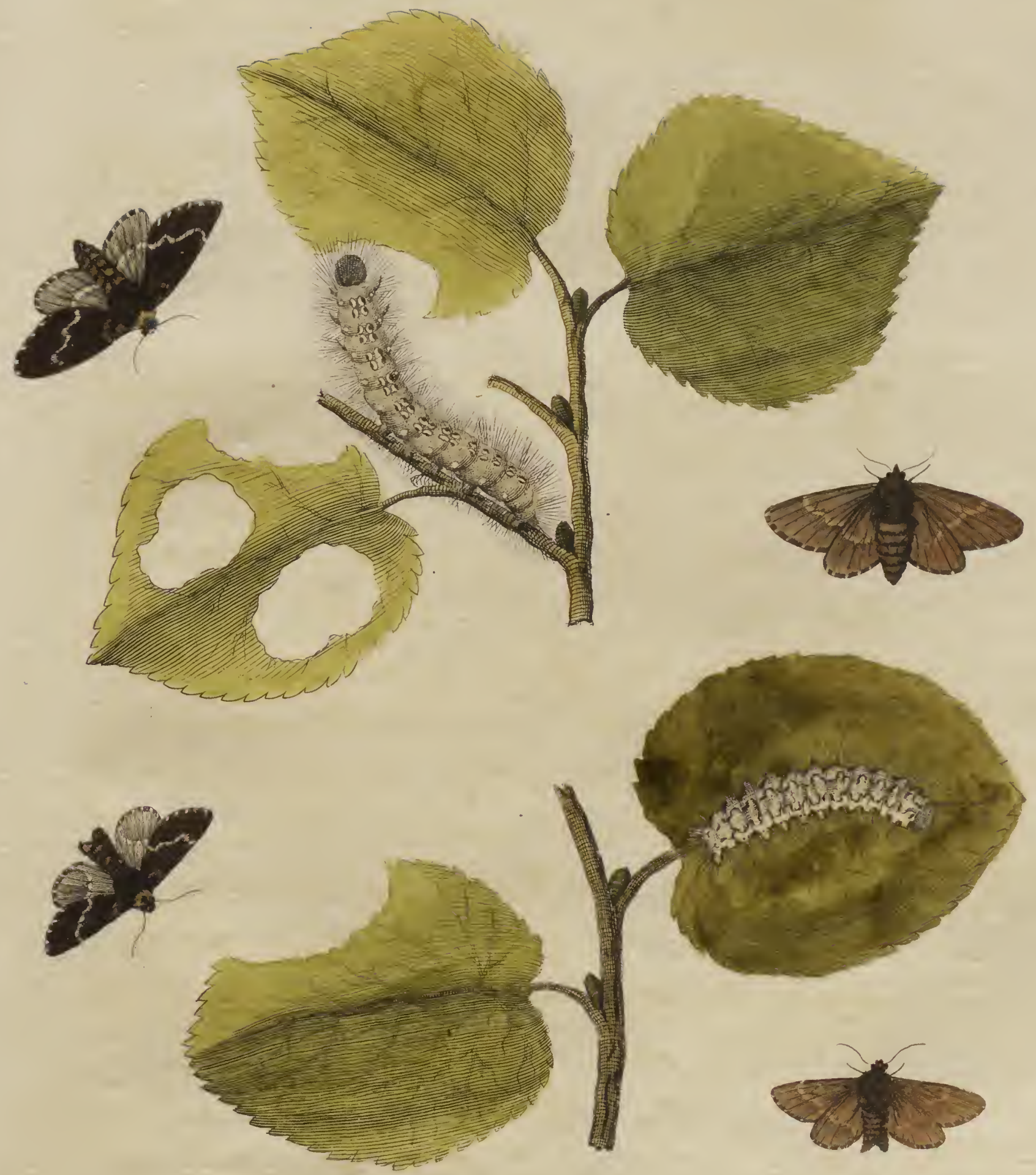

\section{TO THE MOST NOBLE}

Gilliam Duke of Devonshire

This Plake is humbly didicated by Gleaz!' Tlbin. 


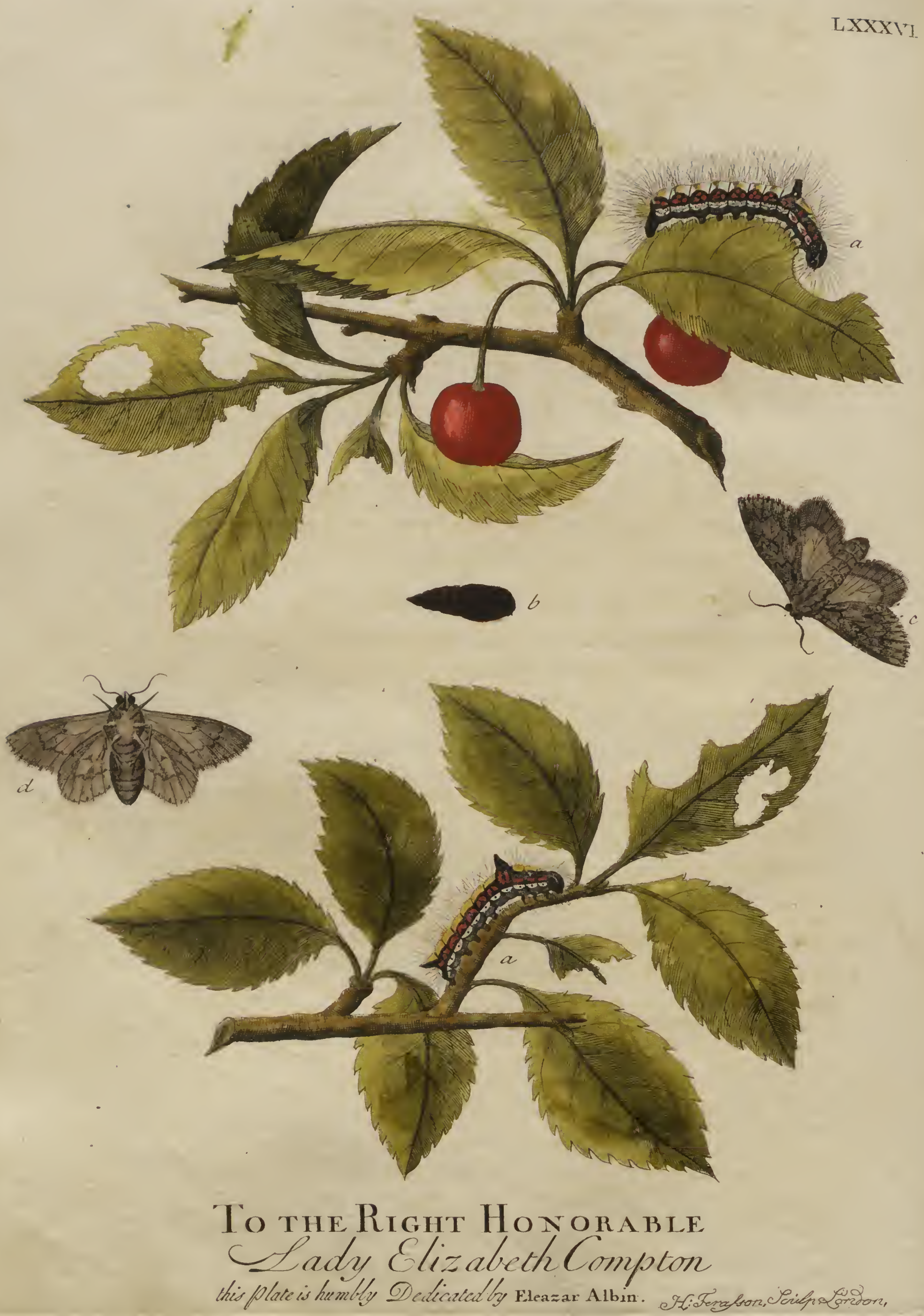


9 9

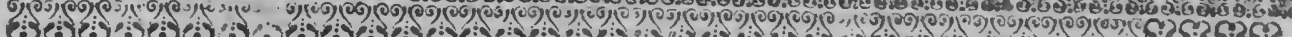

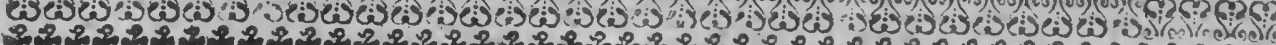

$24{ }^{2}$

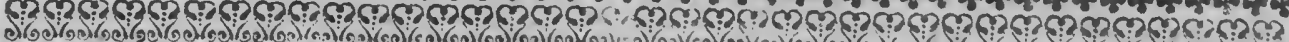
ollow

4 24.

The DEscription of the Eighty Sixth PLATE.

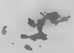

THE CATERPILLAR, $a$, upon the Up. 1 per Branch was finely painted with divers Colours having a Protuberance on the Back. It was found on the Cherry Tree the I 5 th of Fune, and on the 2oth it went into the Earth and changed into a Cbryfalis, $b$; the 14 th of Fuly came the Moth, c, d.

The CAT ER P I L A R on the lower Branch was painted like the former having two Protuberances, one on the Back and another on the Tail. This was found on the Plumb Tree about the latter end of $\mathcal{F} u l y$, and a Motb like the former came the 2.6th of May following. Their Eggs are very fmall, and of the Colour of Vardegreafe. 


\section{The Description of the Eighty Seventh PLa'TE.}

THE Caterpillar, a, was Brown, with two Red 1 Spots near the Tail, and a Row of white Spots on each Side. It was found on the white Thorn the 28 th of May; and the roth of fune it fpun up, and about the middle of Fuly came a white Moth, $c$, $d$, with a brown Tail, from whence it is commonly called the Brown-tail. The Eggs of this CATERPILAR are hatched in Autumn, and the Young feed upon the flethy Part of the Leaf, leaving the upper Skin untouched; they lay themfelves up in Webs all Winter, and as foon as the Buds open, they come forth and devour them in fuch manner that whole Trees and fometimes Hedges for a great way together are abfolutely bare. It will be well worth while for thofe who value their Trees, or Hedges, to have the Webs cut off and deftroyed during the Winter.

The Caterpillar, $e$, was dark Brown, fpotted all over with Red and White. It was found on the white Thorn the 29 th of May, and the $2 \mathrm{~d}$ of Fune it pun it felf up, and changed into a Cbryfalis; the $22 \mathrm{~d}$ of Fune came a white Moth with a fmall black Spot in each upper $W$ ing, the End of their Tail Orange Colour. They lay Eggs of a pale Colour, covering them with a woolly Subltance; the young C A TERPILLARS hatched the I 4 th of Auguft; I fed them 'till the latter End of October; they fpun themfelves up in little Cafes, and to remained till the Spring following. 

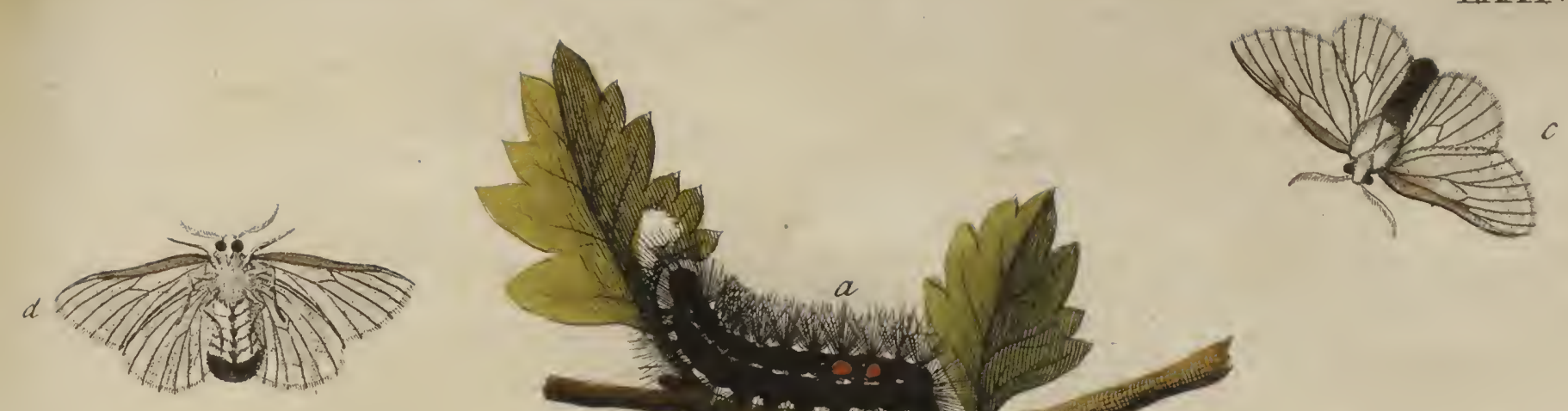

XXXVII 


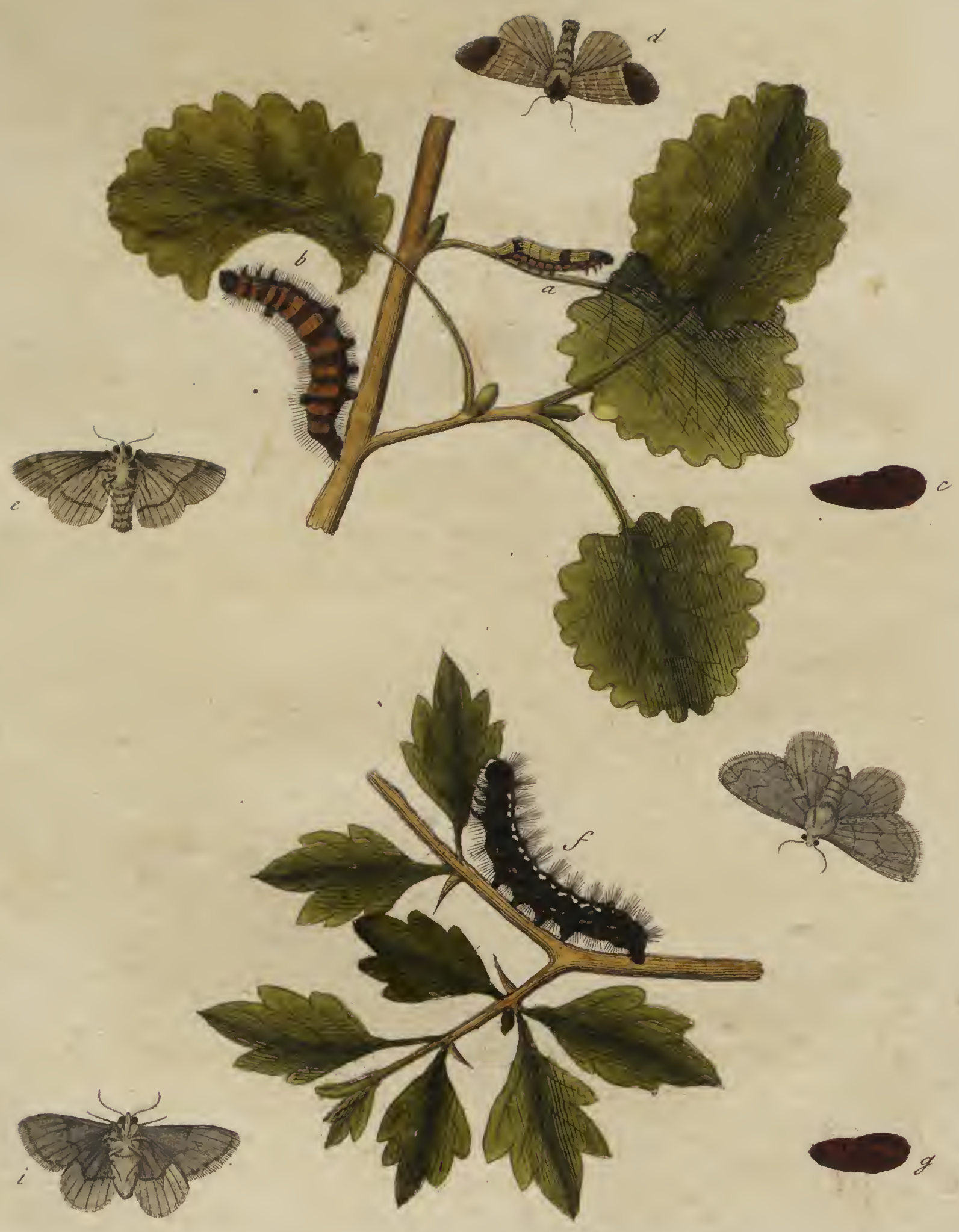

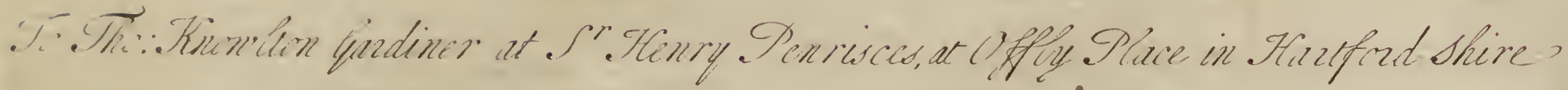
Shis Plate is humbly dedicaced by Gleig:" Alin, 
The DEscription of the Eighty

$$
\text { Eighth Pla Te. }
$$

THE Caterillar, a, was Yellow 1 and Orange Colour. It was taken on the Afpen Tree near Mufel Hill at the Beginning of September; it fpun it felf up in a Web in which it lay two days, and then came out cafting its Skin, the Marks and Colour appear'd as at $b$; it fed 'till the 24th of September, and then fpun it felf up to the Side of the Box; the Moth, came the I 9 th of March.

The Caterpillar, $f$, was dark Brown, fpotted with divers Colours. It was found on the white Ihorn the I 6 th of May (they will feed on the Oak, Hafle, and black Ihorn;) it fpun up the the 28th of May, and changed into Chry $\int_{a}$. lis, g, and the 2oth of Auguft came the Moth, $b, i$. Their Eggs are covered with a dark hairy: Subftance which they lay in Lines of divers Figures on the Barks of the Trees. 
The Description of the Eighty Nintb PL A T E.

HE Caterpillar, a, in the Table
was purplifh fpotted with Red, it had four Tufts of yellow Hair on its Back, two black Tufts like Horns on the Head, and one of the fame Colour on the Tail. It was found feeding on the Apricock Tree the 27th of May, and fpun it felf upat the Beginning of Fune; the Female Moth, $c$, came about the i 6 th of the fame Month, this was without $W$ ings, and after Copulation lays her Eggs on the Web, in which the lay while in Cbryfalis; the Male, $d, e$, of a reddith Brown, with a Spot of White in each upperWing, came the 2 Ift of June. From a Cbryfalis of this kind came the Icbneumon, $f$. See Lifer on Godart, page 80. $N^{\circ} 79$. 


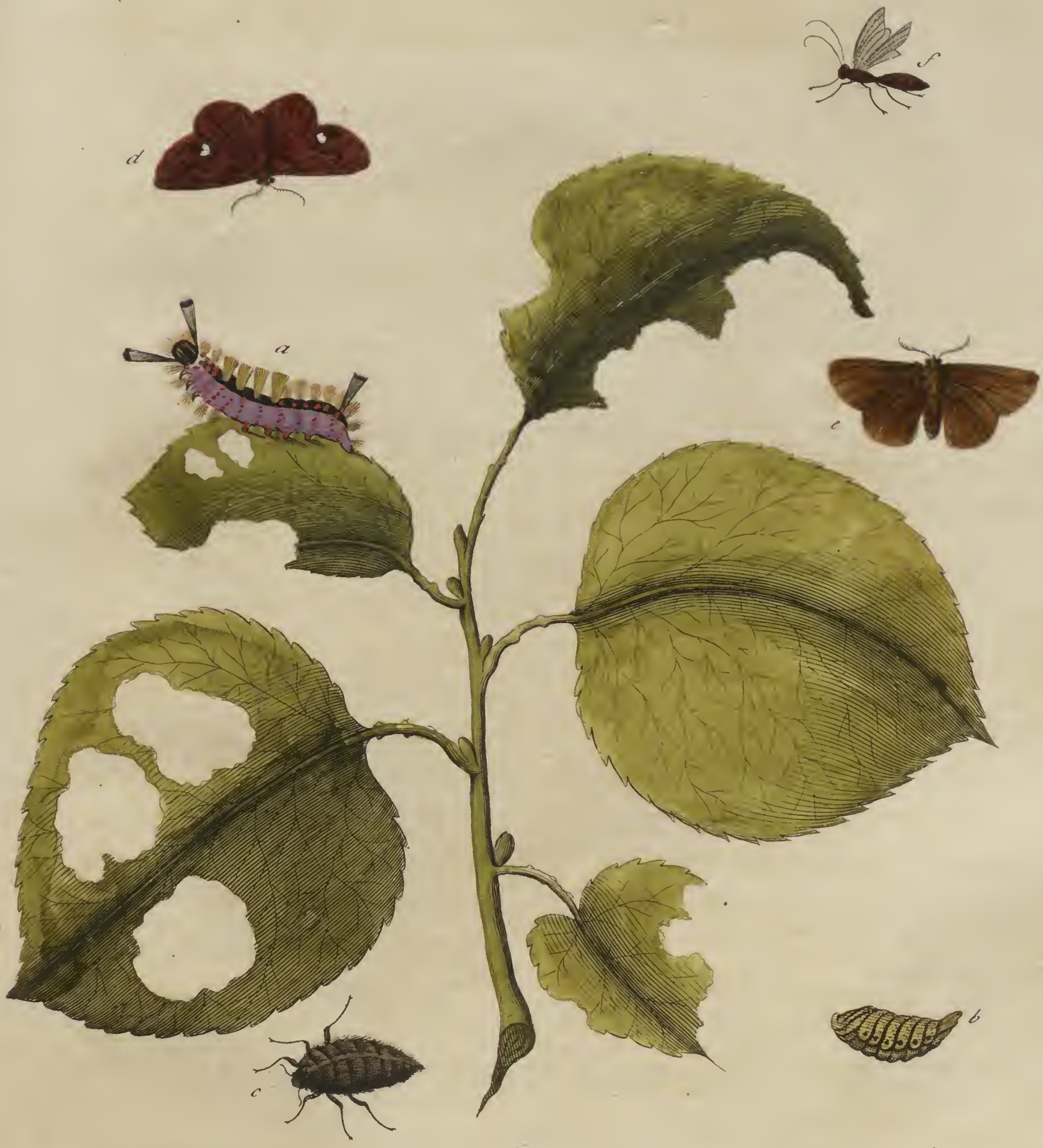

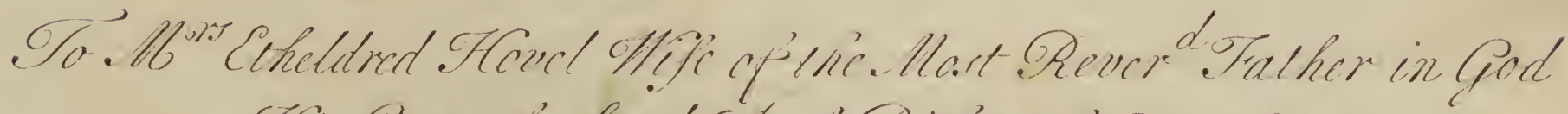

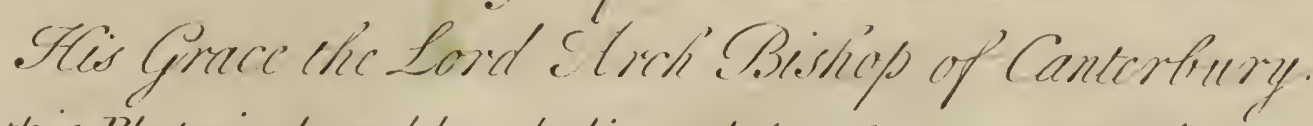
this Plate is humbly dedicated by E1eazar A1bin. 

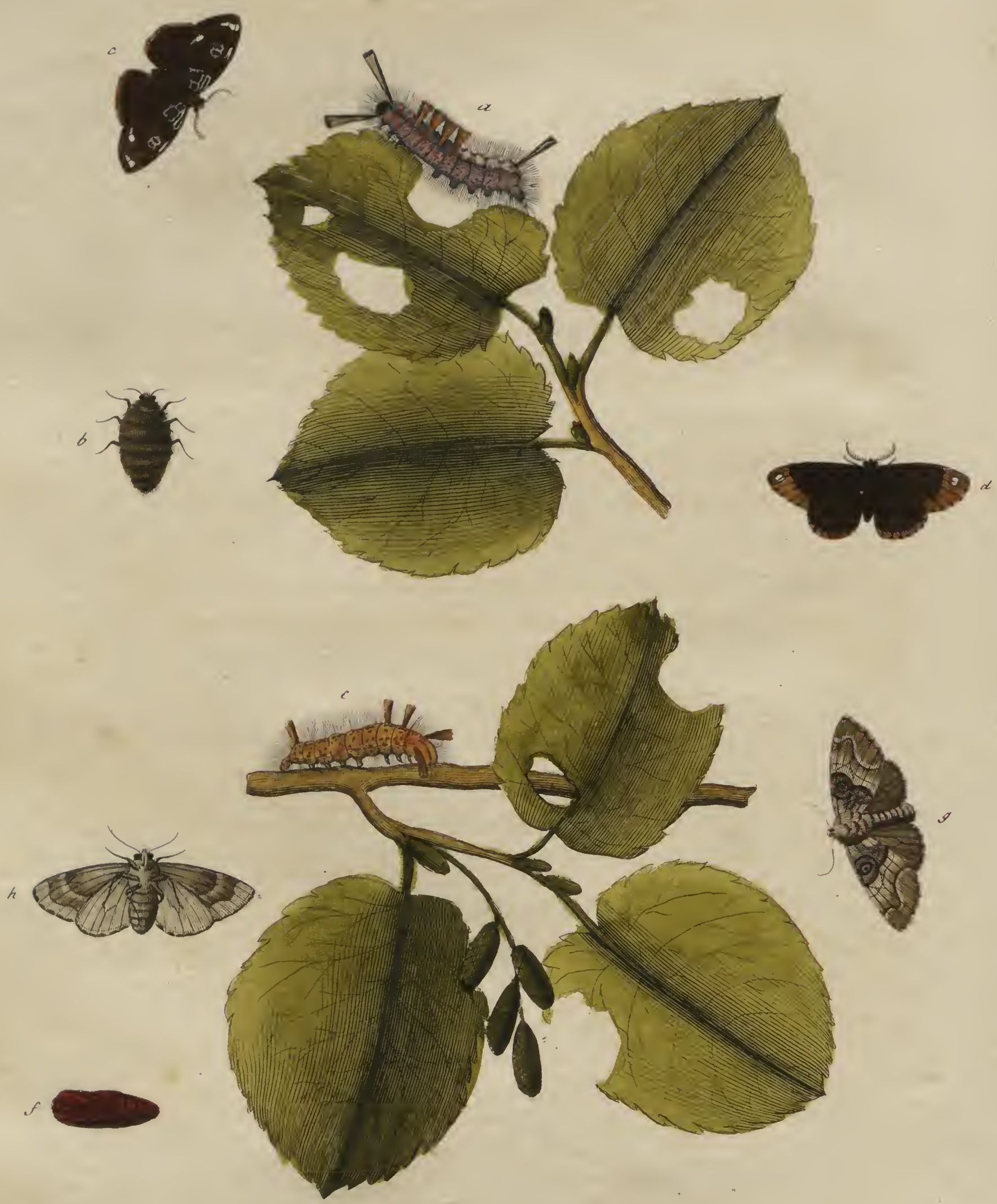

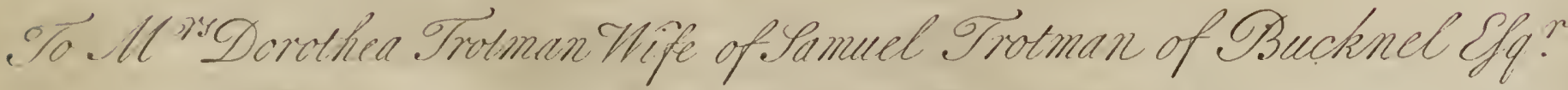
this Plate is humbly dedicated by Eleazar Atbin. 
The Description of the Ninetieth PLATE.

THE Caterpillar, a, was darkifh 1. Purple with red Spots and horned Tufts like the former, the four Tufts on its Back Red. It was found feeding on the Hafle at the latter End of April near Lew/ham in Kent; it fed 'till the rigth of $M a y$, and then fpun up and changed into a Cbryfalis; and the Moth came the 6th of Fune; $c, d$, fhows the Male, and $b$, the Female.

The Caterpillate, $e$, was Orange Colour, with two Tufts on the Head, and one on the Tail, and but two in the middle of the Back of the fame Colour of the CA TER I ILLAR. It was found on the Hafle the Igth of Auguft, and the roth of September it fpun up, and changed into Cbryfalis, $f$; the Moth, $g, b$, came the firft of April. 
The Description of the Ninety Firft Plate.

THE CATERPIllar, $a$, in this Table I was of a yellowifh Green, with an indented Line of Brown on each Side. It was found feeding on the wild Briar at the Beginning of September, and at the latter end of the fame Month it went into the Earth, and changed into Cbryfalis, b; the Moth, $c, d$, came at the latter end of May. It was White motled with Black.

The Caterpillar, $e$, was Brown, and round each Foynt Tufts of thort prickly Hairs, the Head Red. It was found on the white Thorn about the zoth of May near Hornfey-wood, and about the Beginning of Fune it went into the Earth, and changed into Cbryfalis, f Female Moth, g, was without Wings, and came about the middle of April; and the Male, $h, i$, came two Days after. 

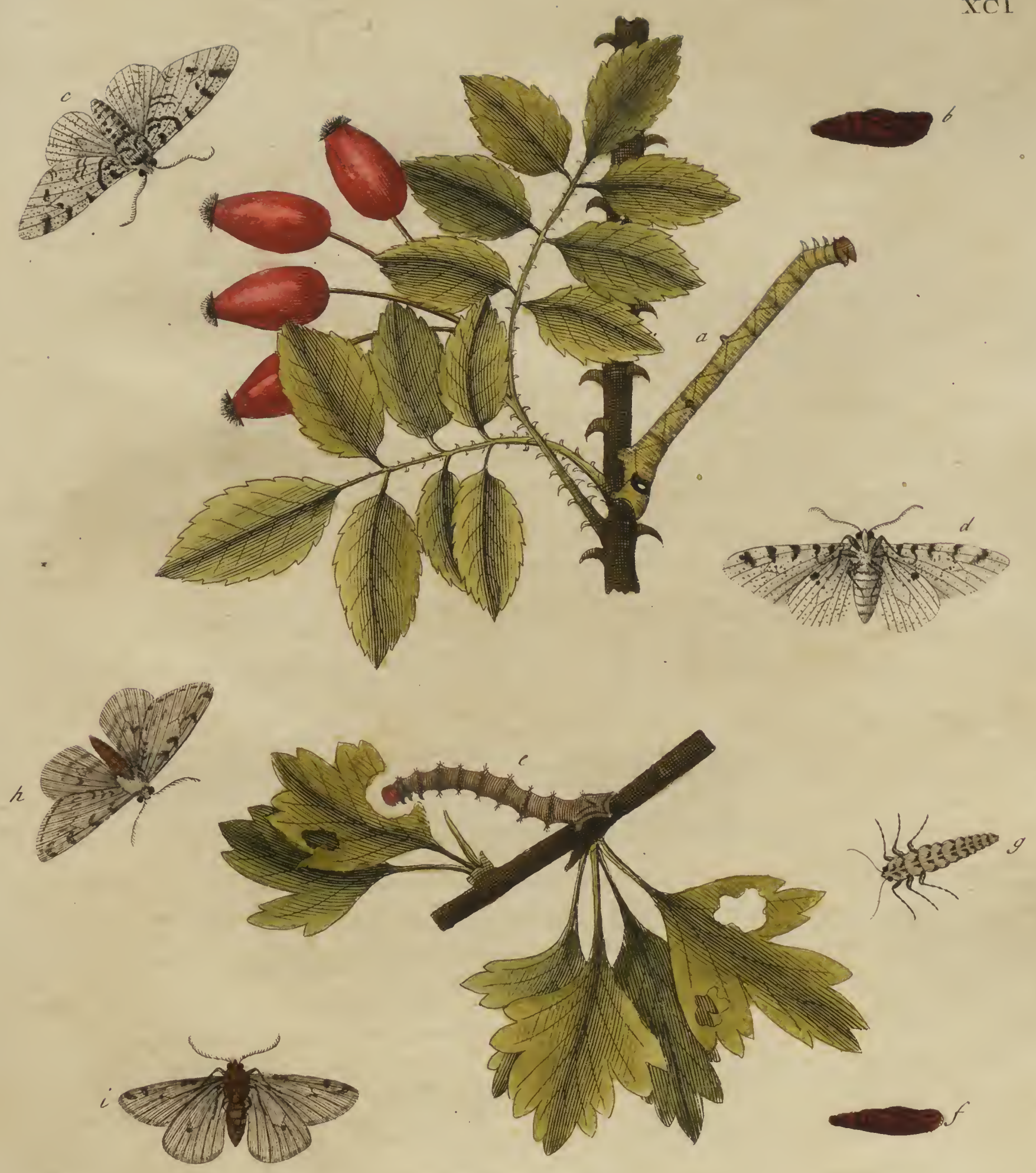

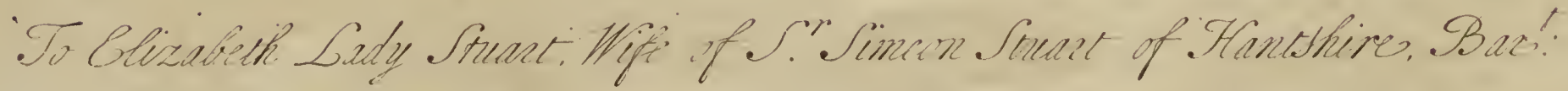
Shis Plate is humbly dedicated by Cleuge" Rlin 


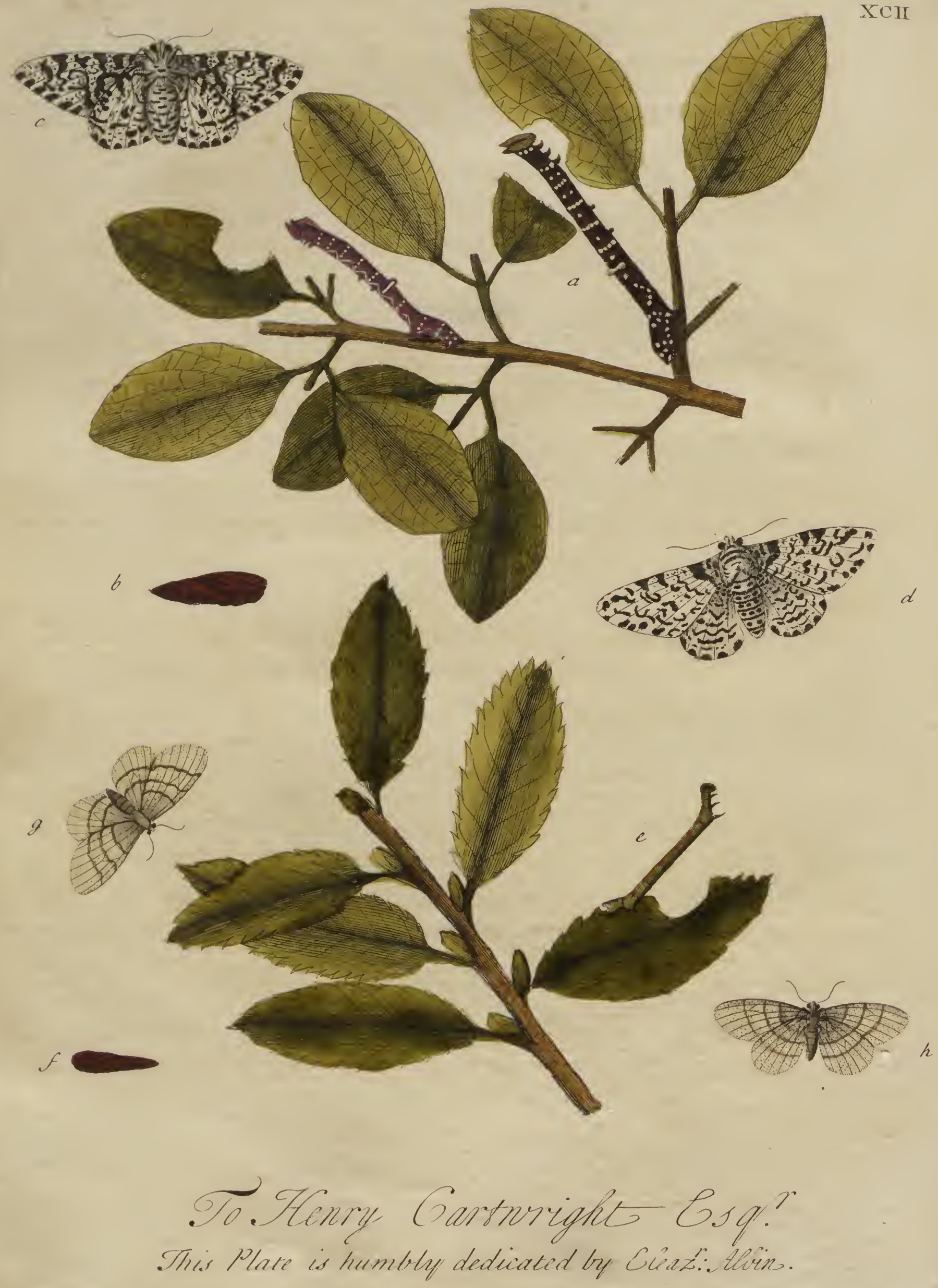


The Description of the Ninety Second Plate.

THE CATERPIL LAR in this Table, while 1 fmall, was of a Rofie-red Colour, with a Circle of white Spots round each 'Foint, as reprefented by the leffer Figure in the Plate, when it grew larger, upon cafting a Skin; it appear'd as at $a$. It was found on the Dog-berry Tree near Muzzle-bill the 26th of Auguf $;$; it went into the Ground the 3d of October, and changed into Cbryfalis, $b$; and the Motb, $c, d$, came about the latter end of May following.

The Ca Ter Pil La R, $e$, was Green, with fmall red Lines on the Back. It was found on the Sallow at the Beginning of September near Hornfey; it fpun it felf up the I 4 th of the fame Month, and changed into Chryjalis; the $23 \mathrm{~d}$ of April came the Moth, $g, b$. 


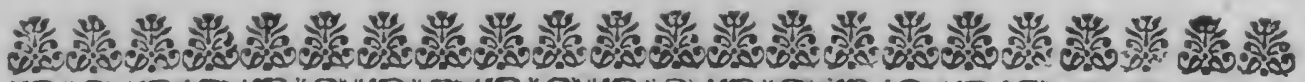
10.3 50.78.

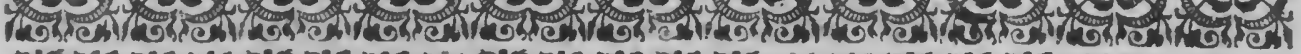
6.7.2.

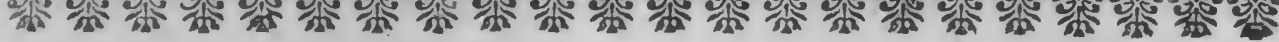

The Description of the Ninety Third PL A T E.

THE Caterpillar, $a$, in this Table 1 was found feeding on the $O a k$ near Hampflead Heath on the 27 th of May; it fpun it felf up in the Leaves at the bottom of the Box, and changed into Cbryfalis, $b$, and the Motb came the igth of Fune.

The Caterpillar, $a$, was taken on the Oak the 7 th of September, and on the I8th of the fame Month it fpun its felf up, and changed into a Crryfalis, $f$; the i 6 th of May came the Motb, $g$, ho 


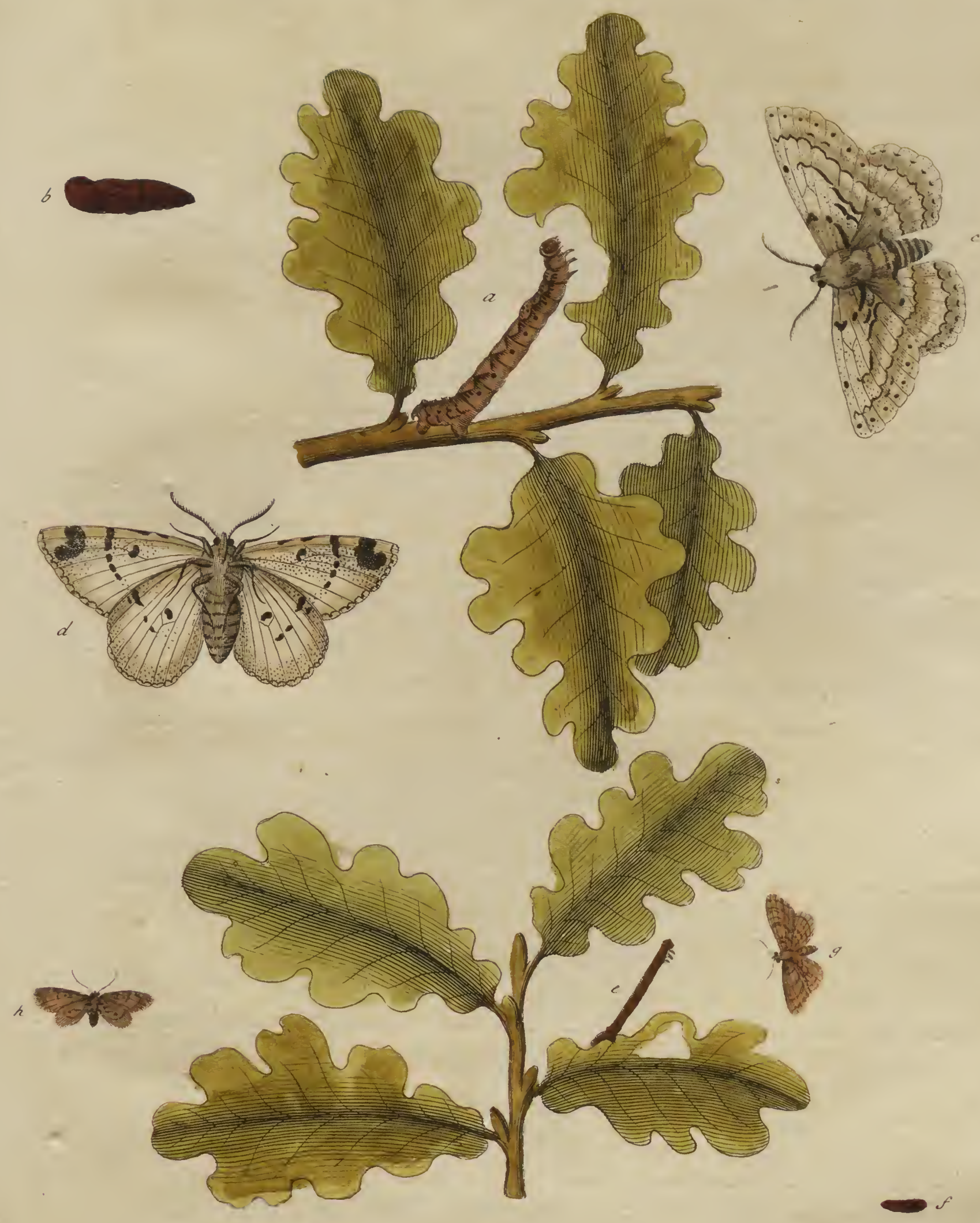

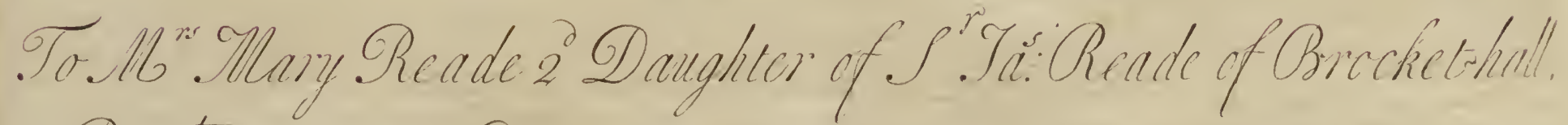

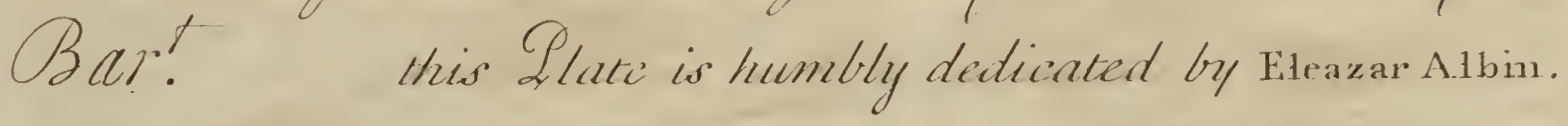




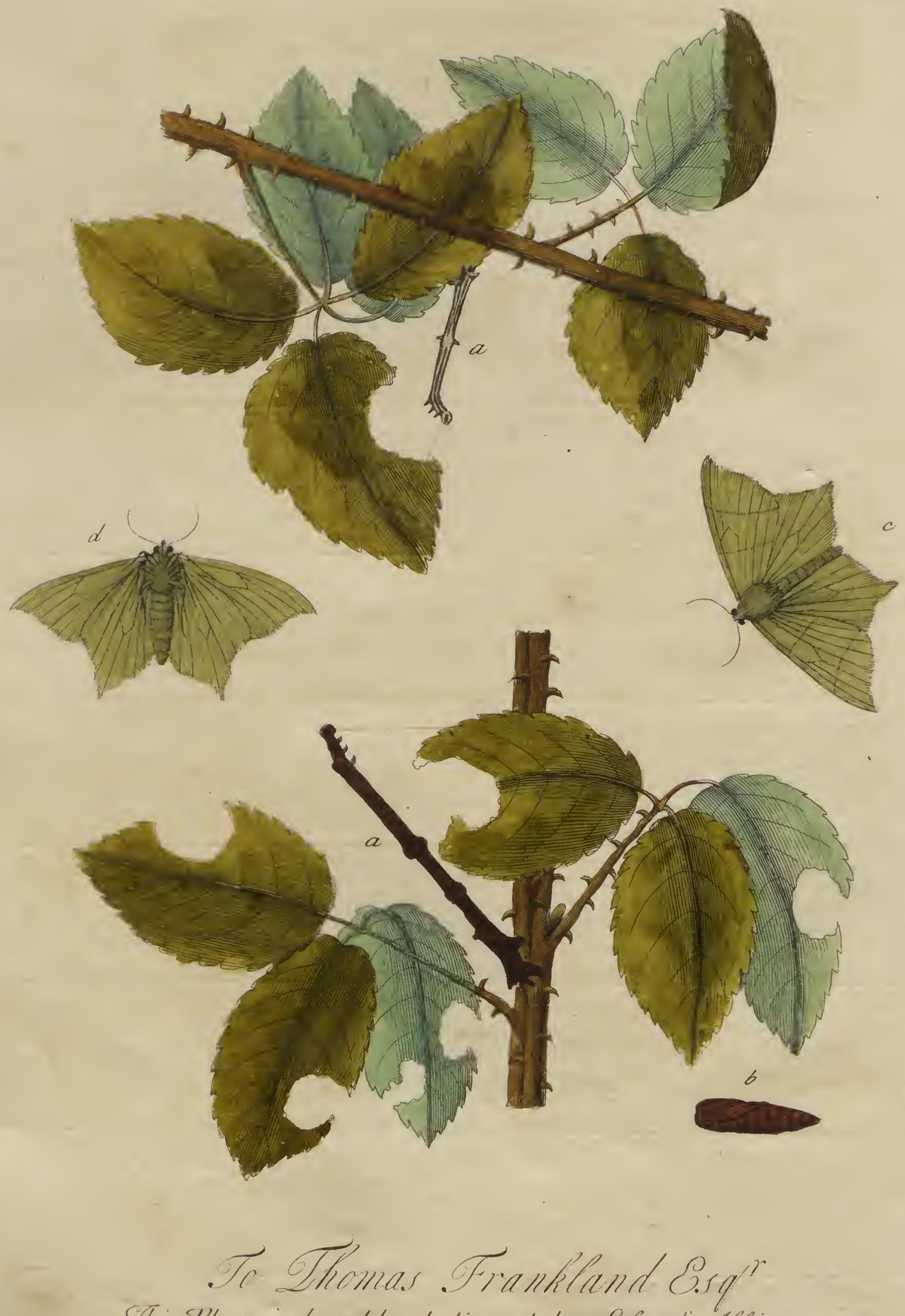

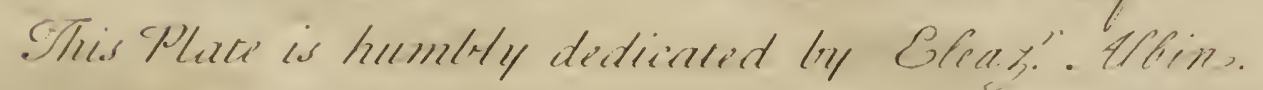


The Description of the Ninety Fourth PL A TE.

\section{THE Caterpillar, a, was Afh Co- 1 lour, with Lines of White. It was found} feeding on Bramble Leaves the inth of Septem$b_{i} r$ near Highrate. It fed all the Winter till the 5 th of March, and then fpun fome of the Leaves together like a Bag which it hung by four or five threds, fo that upon touching it fwung to and fro; in which it changed into a Chry $/ a$. lis, c; the Moth, d, e, came the 2 If of April.

The Caterpillar, $b$, was of the fame Kind, tho' differing in Colour; and changed about the fame Time, and in all other Refpects was as the former. See Liffer on Godart, page 14. $N^{\circ} 10$. 
The Description of the Ninety

$$
\text { Fifth PLate. }
$$

THE C.Aterpillar, $a$, in the 7able 1 was found on the white Thorn the 13th of September; it fpun it felf up on the 24th of the fame Month, and changed into Chryfalis, $b$; the Moth, $c, d$, came about the middle of May, it was the fame with $g, b$, in the $42 \mathrm{~d}$ Table. I found feveral of thele Caterpiliars which varied very much in Colour, fome being much lighter, and fome darker; but they all had Protuberances on their Backs.

The Caterpillar, $e$, was found on the wbite Thorn the 15th of September, it was of a greenifh Colour; and the 17 th of the fame Month it fpun up in the Leaves, and changed into Chryjalis, $f$, and the $3 \mathrm{~d}$ of April came a yellow Moth, $g, b$, with brown Clouds towards the Pinions of the upper Wings. 

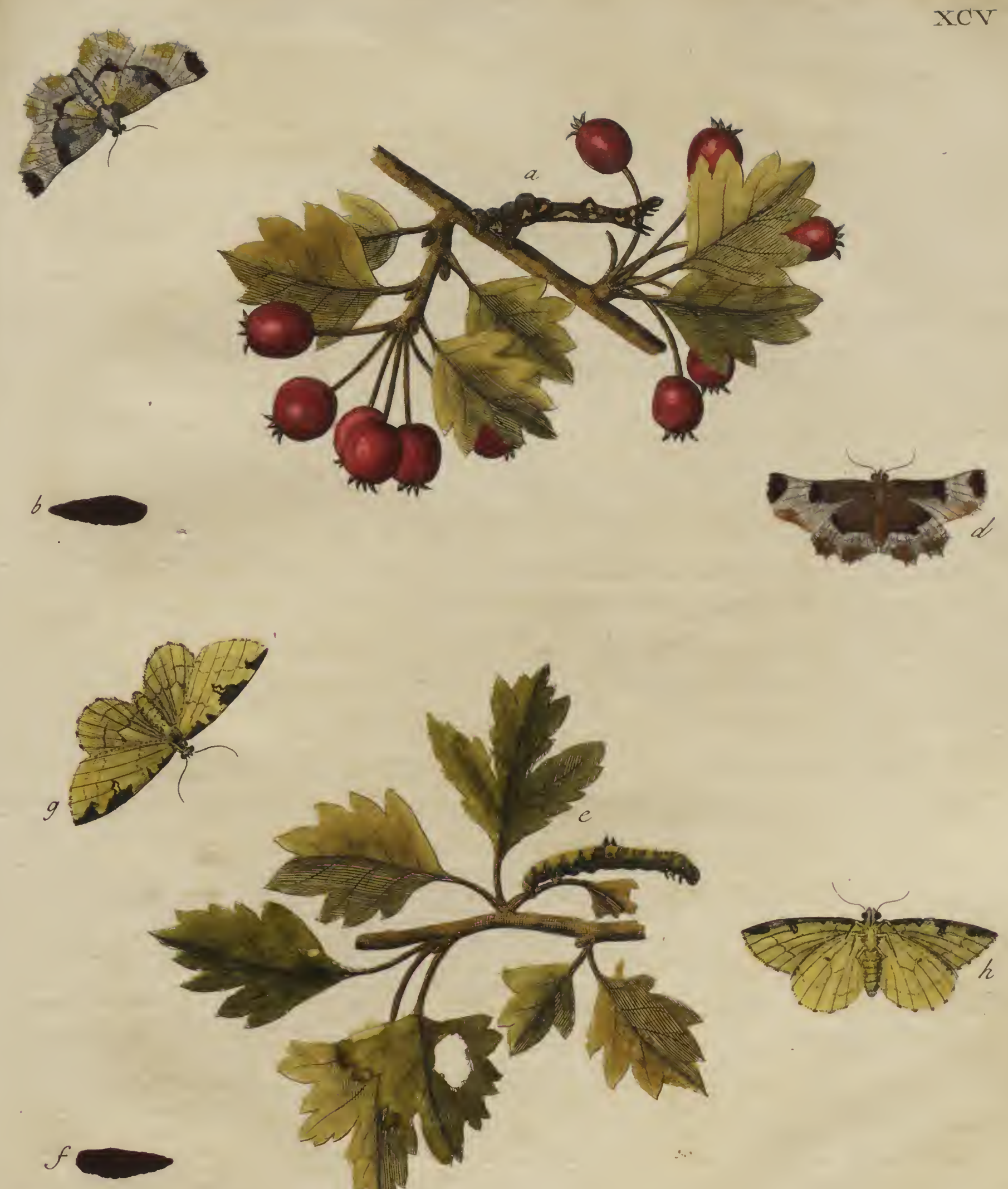

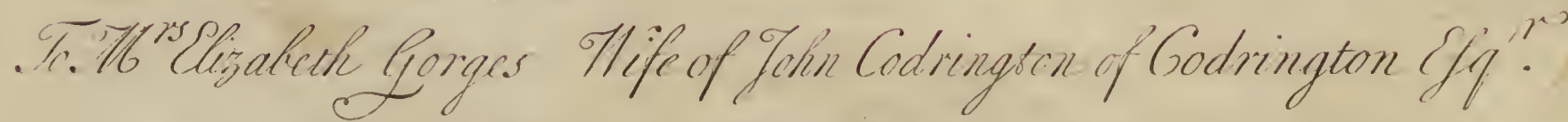

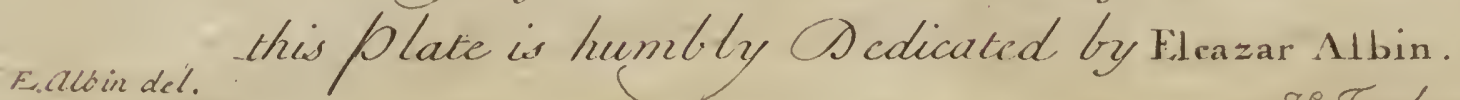



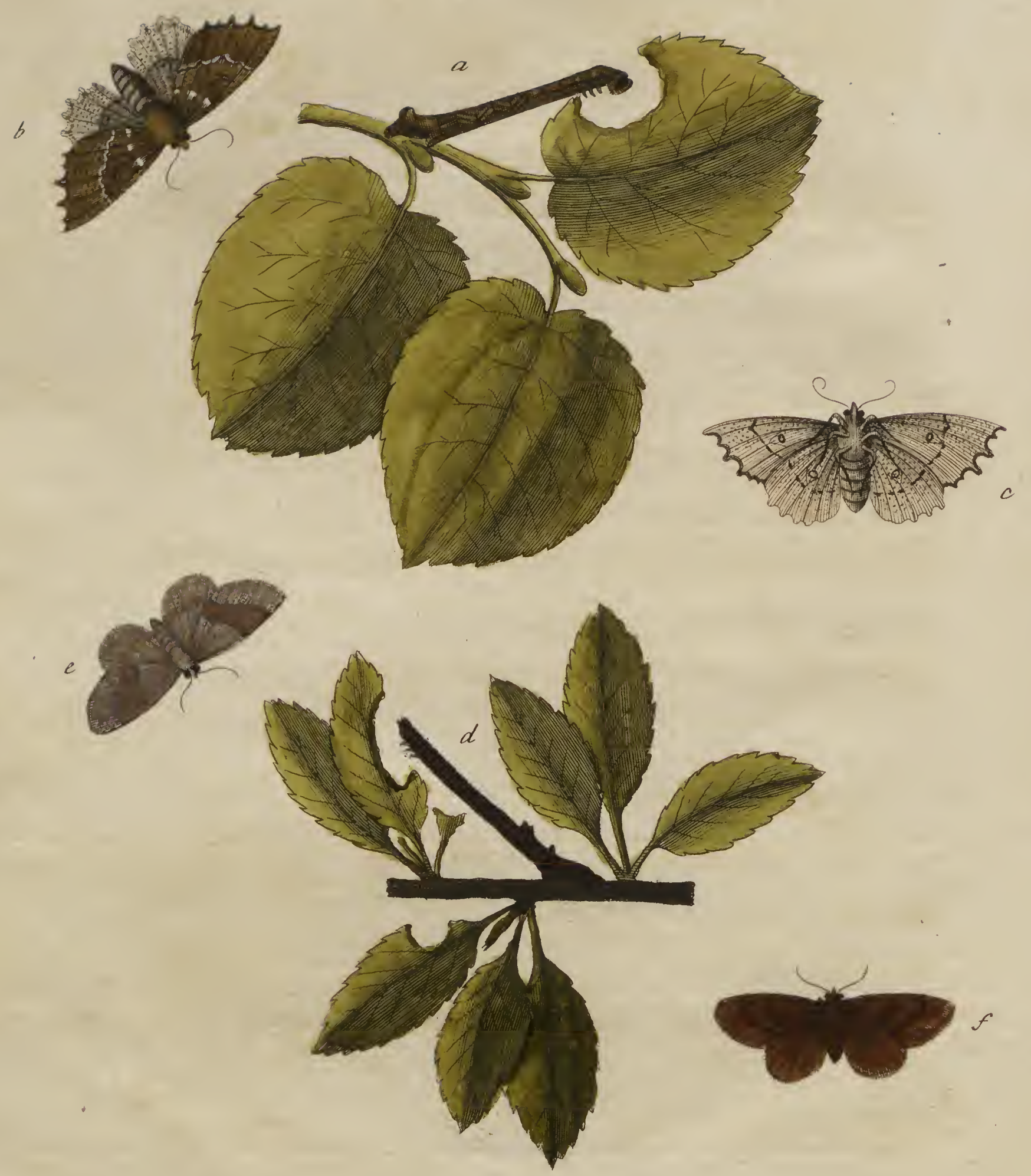

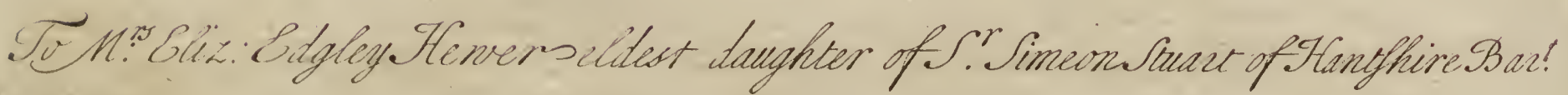
This Plate is humbly dedicated by Gluas. Melin 
The Description of the Ninety Sixth Plate.

THE Caterpillar, a, in this Table, 1 was found feeding on the Hafle the I4th of September near Cain Wood; and the I th of October it fpun it felf up in one of the Leaves, and changed into a Chryfalis; the fcallopt-wing'd Moth, $b, c$, came the I 9 th of April.

The Caterpillar, $d$, was a of dark Red Colour, and had three Protuberances on its Back near the Tail. It was found on the black Thorn near Bowes-farm the gth of Auguft, and fpun it felf up between the Leaves and the Box the 7 th of September; the Moth, e, f, came the 2oth of March following. 
The Description of the Ninety. Seventh PLA'TE.

THE Caterpiliar, $a$, was a Kind of 1 Looper, it was hairy, (which is not very common among them;) and beautifully marked with feveral Colours. It was found on the Hafle the ift of Fune, and the I 4 th of the fame Month it went into the Ground, and changed into a Cbryfalis, $b$, and at the Beginning of $A$ pril came the Moth, $c, d$.

The Caterpilla It was found on the wbite Lady's-bedftraw in the Mar/bes near Rotberbith the $3 \mathrm{~d}$ of September; it fpun it felf up the 12 th of the fame Month, and changed into Cbryfalis, $f$; and the 2oth of February came the Moth, g, $b$. 

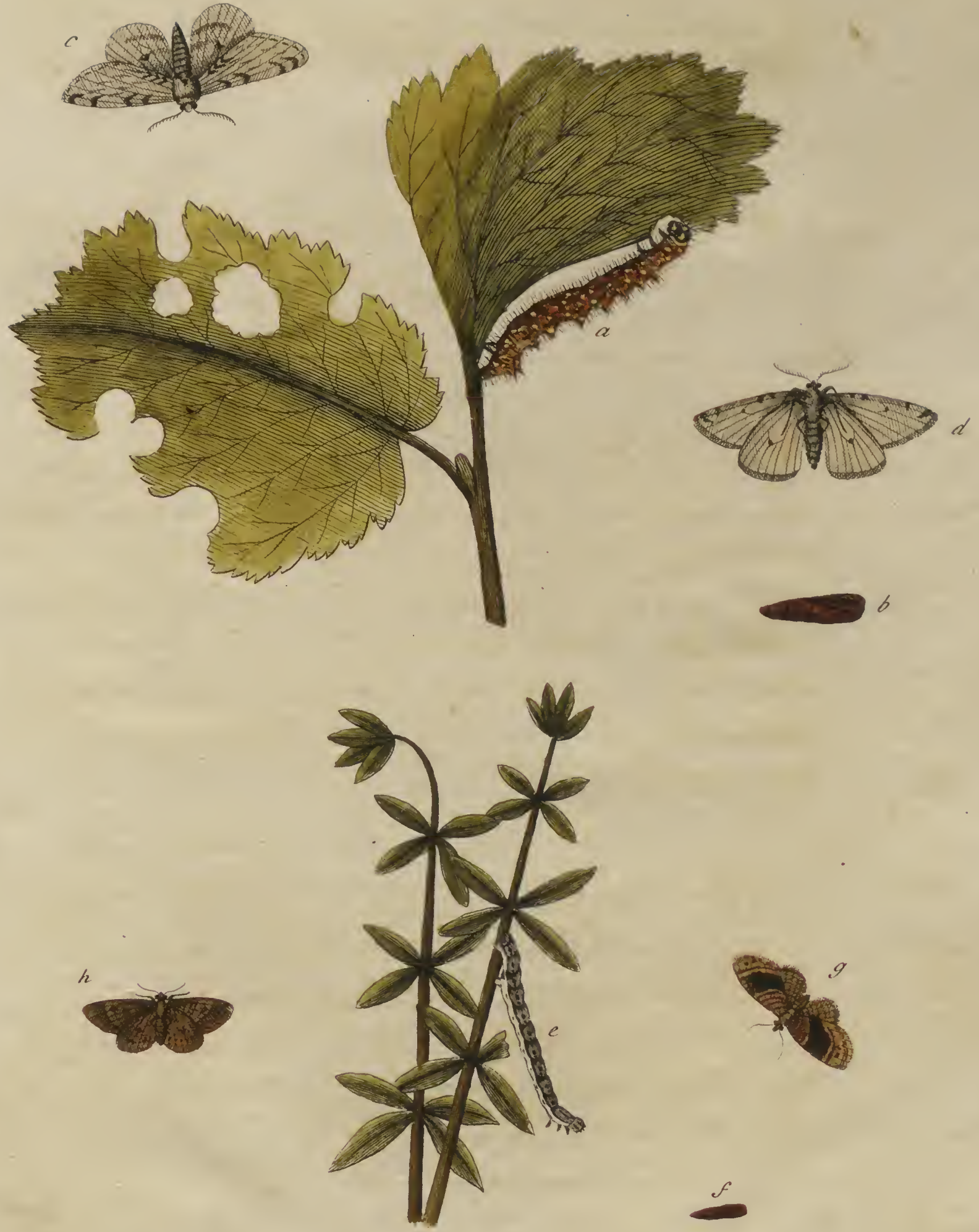

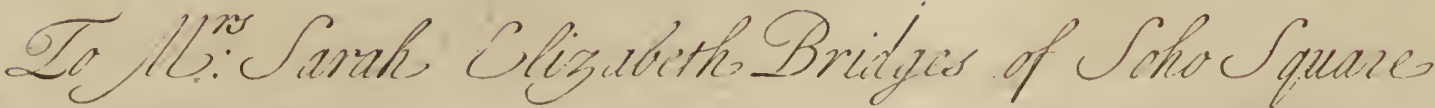
Shis Plats is humbly dedicated Iny Gleaz." Alions 

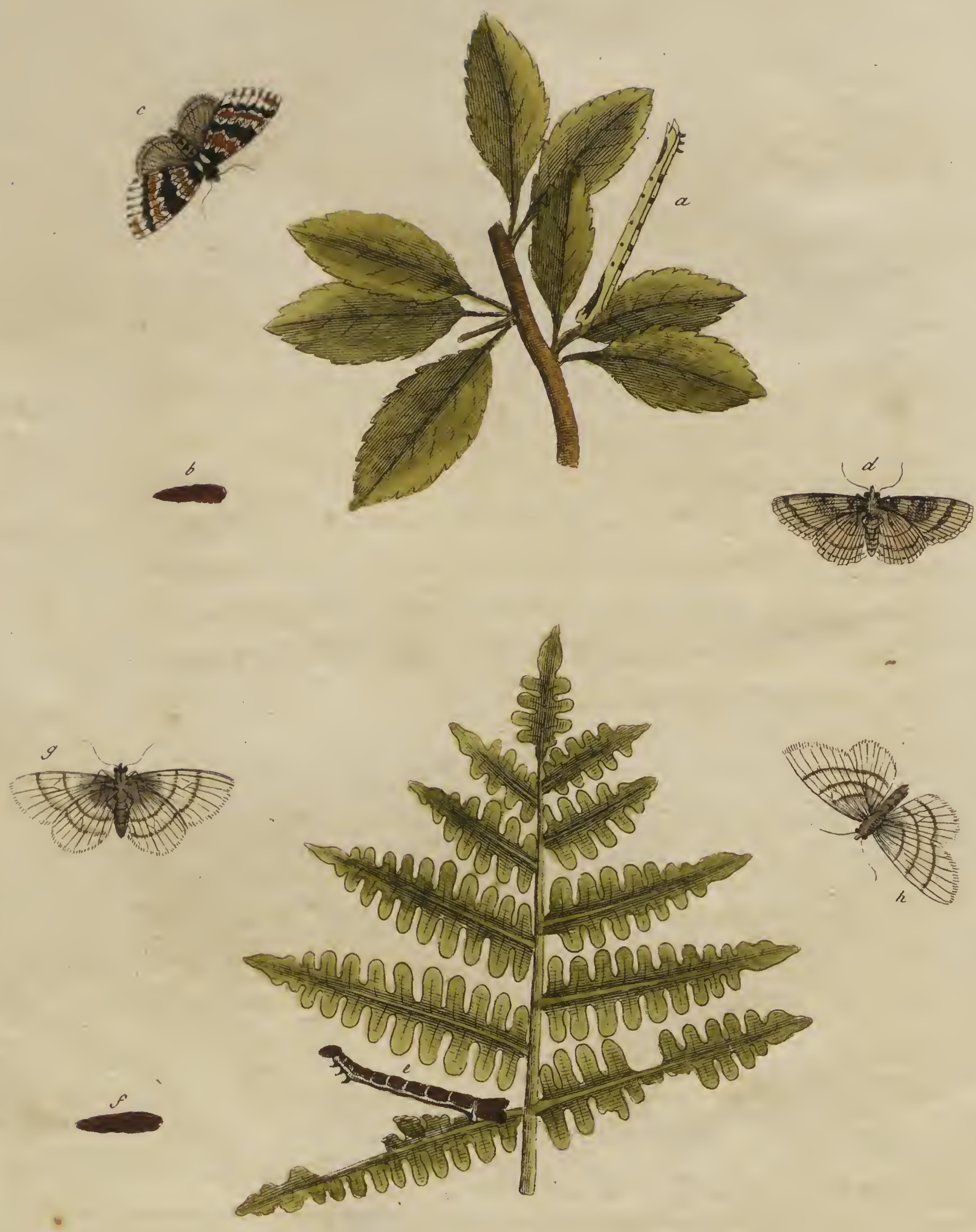

To Gdmard Sachson of the Mlidte Temple Gost! This Plare is humbly dedicateds lyy Blenzirr. Allins, 
The Description of the Ninety Eighth Plate.

THE Grenifh Caterpillar, $a$, was I found feeding on the black Thorn near Highrate the 4th of September, and the 6th of October it fpun it felf up in the Leaves, and changed into Cbryfalis, $b$; and the $22 \mathrm{~d}$ of Marcb came the Motb, $c, d$, the upper Wings Yellow and White, with three dark Clouds a-crofs them, the under Wings and under Side of a light Hair Colour.

The Caterpillar, $e$, was of browninh Red, with a line of White on each Side, and a Streak of the fame at each Foint crofs the Back. It was found on the Fern the I 3 th of September in Bißhop's-wood; it fpun up the 16th of the fame Month, and changed into Cbryfalis $f$; the Moth, $g, b$, came the I 2 th of May. 
The Description of the Ninety Ninth PLate.

THE CATER PILLAR at, $a$, was green1 ifh Yellow, fpotted with Red on the Back. It was found on the Hafle about the middle of September, and fpun it felf up about the 2oth of the fame Month, and changed into Cbryjalis $b$; the Moth, $c, d$, came about the middle of May following.

The Caterpillar, $\varrho$, was pale Green, clouded and fpotted with Brown. It was found feeding on the Horfe-radighthe 18 th of Septem$b e r$, and the $23 \mathrm{~d}$ of the fame Mont $b$ it went into the Ground, and changed into Chryfalis; the Moth, g, $b$, came the gth of May. 

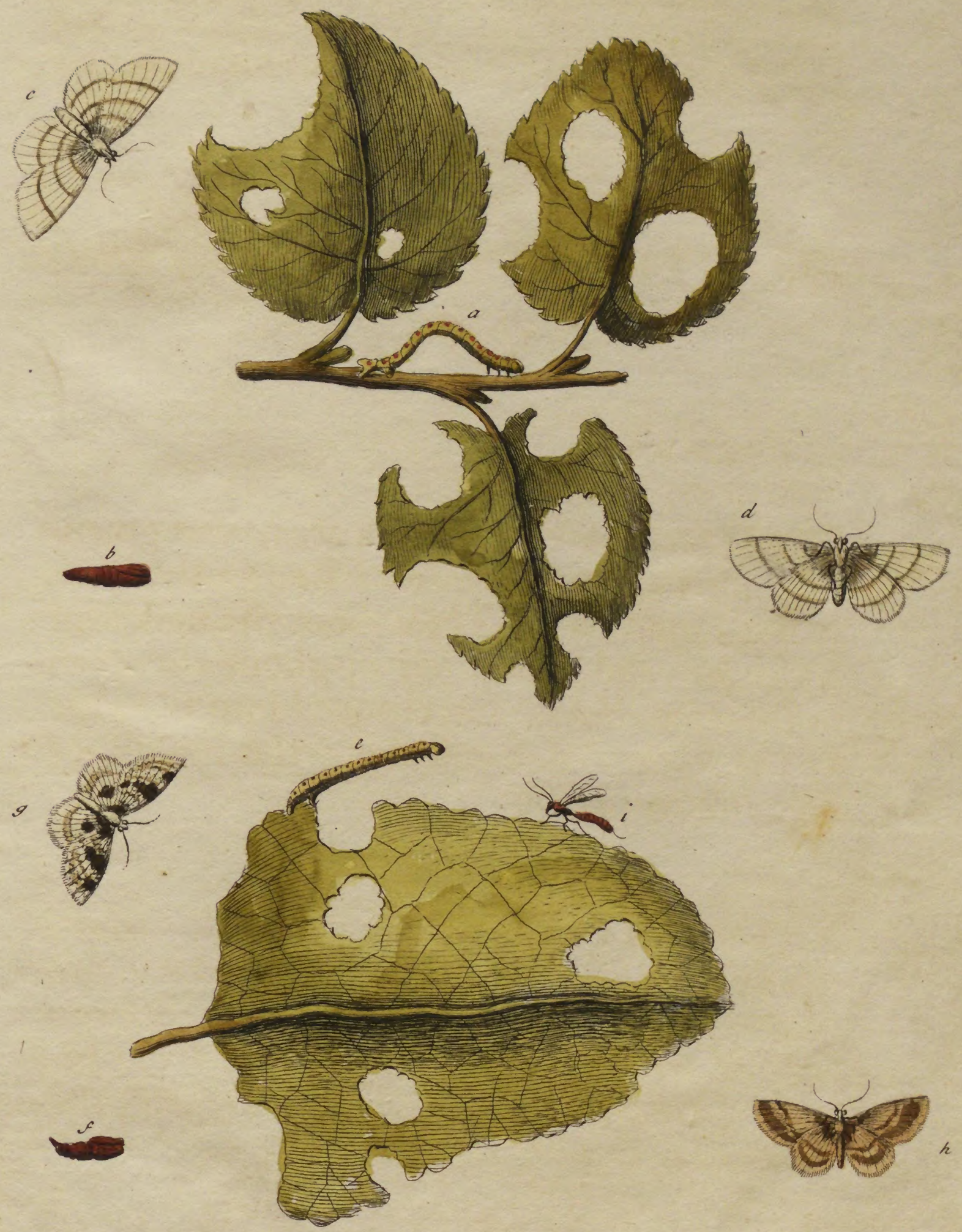

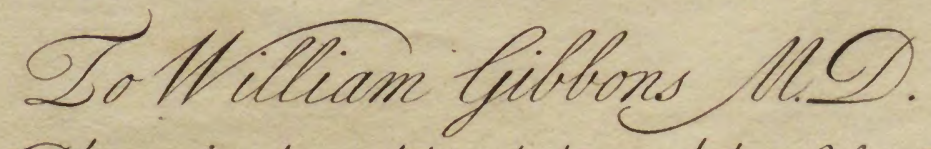

This Slave is humbly dedicated by Gleng: Mbin, 

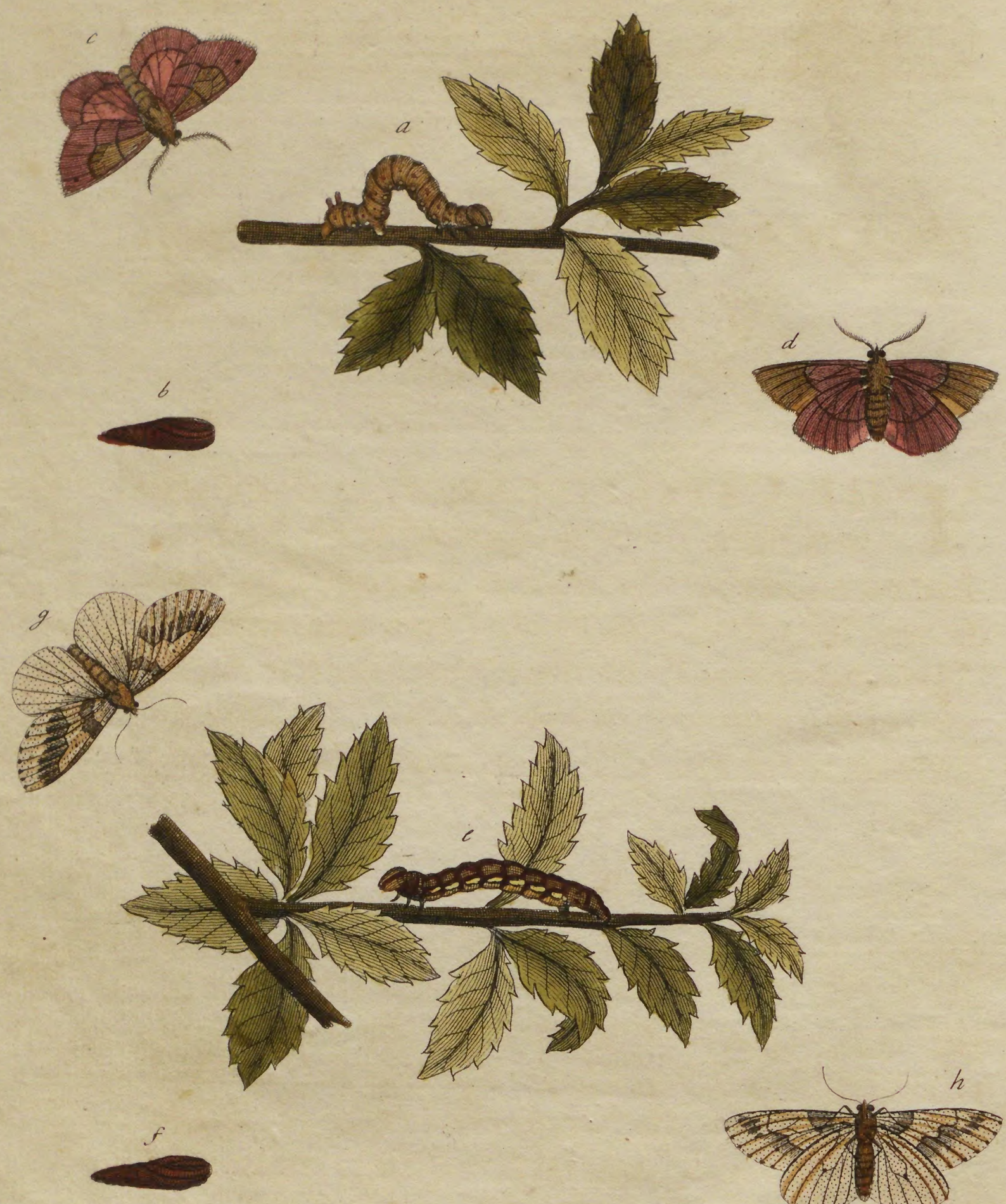

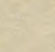


The Description of the Hun dredtb Plate.

\section{THE Caterpillar, $a$, in this Table I was light Brown, fpotted with Red; it} had two red Protuberances at the end of its Tail. It was found on the black Thorn the roth of May, and the $25^{\text {th }}$ of the fame Montb it went into the Eartb and changed into Chryfalis, b; and the latter end of September came the Moth, $c, d$.

The CATERPILAR, e, was Brown and fpotted with Yellow. It was found on the black. Thorn the 18 th of May, and the 26 th of the fame Month it went into the Eirtb and changed into Cbryfalis, $f$; and the 6 th of $\mathrm{No}_{\mathrm{o}}$ rember came the Moth, $g, h$, the Female of which is without Wings, and lays her Eggs near the Place where the lay while in Cbryjalis. 